口 MELITA PUKLEK LEV PUŠČEK IN KLAUDIJA ŠTERMAN IVANČIČ (UR.)

\title{
MOTIVACIJSKI DEJAVNIKI V IZOBRAŽEVANJU MLADINE IN ODRASLIH
}

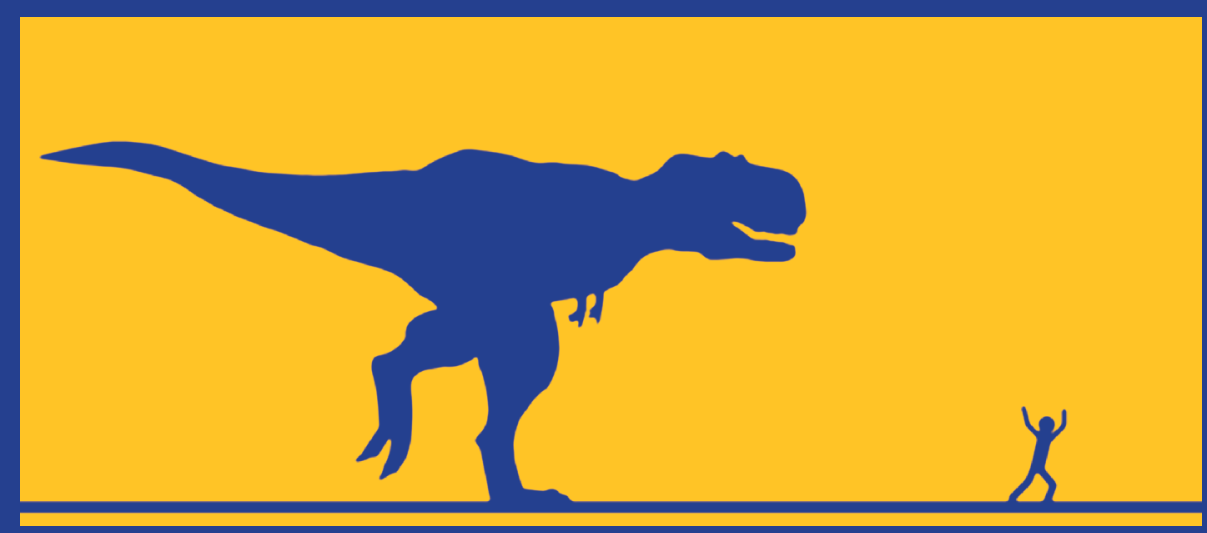



MOTIVACIJSI DEJAVNIKI • 


\section{口ob}


ם MELITA PUKLEK LEVPUŠČEK IN KLAUDIJA ŠTERMAN IVANČIČ (UR.)

\section{MOTIVACIJSKI DEJAVNIKI V IZOBRAŽEVANJU MLADINE IN ODRASLIH}


Melita Puklek Levpušček in Klaudija Šterman Ivančič (ur.) Motivacijski dejavniki v izobraževanju mladine in odraslih znanstvena monografija

Digitalna knjižnica

Uredniški odbor: Igor Ž. Žagar (Educational Research Institute \& University of Primorska),

Jonatan Vinkler (University of Primorska), Janja Žmavc (Educational Research Institute),

Alenka Gril (Educational Research Institute)

Zbirka: Documenta, 5

Glavni in odgovorni urednik: Igor Ž. Žagar

Urednica zbirke: Alenka Gril

Recenzenta: Andreja Barle Lakota, Miran Lavrič

Tehnični urednik, oblikovanje, prelom in digitalizacija: Jonatan Vinkler

Lektor: Davorin Dukič

Založnik: Pedagoški inštitut

Gerbičeva 62, SI-1000 Ljubljana

Ljubljana 2013

Za založnika: Mojca Štraus

ISBN 978-961-270-189-5 (pdf)

http://www.pei.si/ISBN/978-961-270-189-5.pdf

ISBN 978-961-270-188-8 (html)

http://www.pei.si/ISBN/978-961-270-188-8/index.htm

DOI: https://www.doi.org/10.32320/978-961-270-189-5

\section{2013 Pedagoški inštitut/Educational Research Institute}

Projekt Motivacijski dejavniki v izobraževanju mladine in odraslih se je izvajal v okviru projekta Ugotavljanje in zagotavljanje kakovosti v izobraževanju in usposabljanju - Evalvacija vzgoje in izobraževanja na podlagi mednarodno priznanih metodologij, ki ga sofinancirata Evropski socialni sklad Evropske unije in Ministrstvo za izobraževanje, znanost in šport Republike Slovenije.

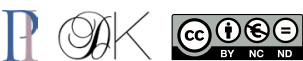

CIP - Kataložni zapis o publikaciji

Narodna in univerzitetna knjižnica, Ljubljana

$37.015 .3(0.034 .2$

MOTIVACIJSKI dejavniki v izobraževanju mladine in odraslih [Elektronski vir] : znanstvena monografija / Melita Puklek Levpušček in Klaudija Šterman Ivančič (ur.). - El. knjiga. - Ljubljana : Pedagoški inštitut, 2013. - (Digitalna knjižnica. Documenta ; 5)

ISBN 978-961-270-188-8 (html)

ISBN 978-961-270-189-5 (pdf)

1. Puklek Levpušček, Melita

270083840 


\section{Vsebina}

Kazalo tabel 13

Kazalo slik $\quad 15$

$\begin{array}{ll}\text { Predgovor } & 17\end{array}$

Melita Puklek Levpušček, Anja Podlesek in Klaudija Šterman Ivančič

- Motivacijski dejavniki bralnih dosežkov v raziskavi PISA 2009

Motivacija za branje 21

Učne in metakognitivne strategije $\quad 28$

$\begin{array}{ll}\text { Raziskovalni cilji } & 32\end{array}$

Predstavitev raziskave PISA 2009

Definicija bralne pismenosti 33

Lestvica bralne pismenosti 34

Ciljna populacija v raziskavi PISA 2009

Vprašalnik v raziskavi PISA 2009

Profil slovenskih dijakov na šestih ravneh bralne pismenosti v raziskavi PISA 200937

Opis ravni dosežkov na šestih ravneh bralne pismenosti 38

Motivacija za branje v Sloveniji in drugih državah 40

Bralni dosežki 40

Bralne aktivnosti ter metakognitivne in učne strategije 43

Branje za zabavo $\quad 44$ 
Indeks uživanja v branju

Indeks različnosti bralnega gradiva

Indeks dejavnosti branja na spletu

Metakognitive in učne strategije

Metakognitivne strategije: indeks strategij za razumevanje in pomnjenje besedila 54

Metakognitivne strategije: indeks strategij povzemanja besedila

Učne strategije: memoriranje, elaboracija, kontrolne strategije $\quad 57$

Stališča do šole in pouka 60

Indeks discipline v razredu pri pouku materinščine 61

Indeks zaznane učiteljeve spodbude pri bralnih aktivnostih $\quad 63$

Indeks zaznanega pozitivnega odnosa učiteljev do dijaka $\quad 67$

Bralni dosežki glede na indeks socialno-ekonomskega položaja družine $\quad 69$

Učni dejavniki bralnih dosežkov glede na spol $\quad 71$

Bralni profili slovenskih dijakov $\quad 72$

Bralni dosežki po profilih $\quad 72$

Profil slovenskih dijakovnatrehravneh bralnepismenostizvidikabralnega procesa 77

Motivacija za branje v različnih srednješolskih izobraževalnih programih $\quad 85$

Metakognitivne strategije 90

Učne strategije 91

Branje za šolo $\quad 92$

Bralna motivacija $\quad 92$

Pouk slovenščine $\quad 93$

Uporaba IKT 94

Uporaba knjižnice $\quad 95$

Stališča do šole $\quad 95$

Družinsko okolje 95

Primerjava bralnih dosežkov skupin bralcev v različnih izobraževalnih programih 96

Motivacija za branje glede na spol $\quad 97$

Primerjava dosežkov dijakinj in dijakov v različnih skupinah bralcev 99 
Diskusija in praktične implikacije

100

Primerjava motivacijskih, učnih in socialnih dejavnikov bralne pismenosti

na Finskem, Norveškem in v Sloveniji

100

Bralni profili slovenskih dijakov

104

Bralni profili, izobraževalni program in spol

105

Literatura

111

Darja Kobal Grum, Janez Kolenc† in Manca Seničar • Povezanost med motivacijo za izobraževanje, tekmovalnostjo in različnimi področji samopodobe pri študentih

Notranji in zunanji motivacijski viri $\quad 115$

Motivacija za učenje in izobraževanje 122

$\begin{array}{ll}\text { Tekmovalnost in motivacija } & 125\end{array}$

Samospoštovanje in motivacija $\quad 127$

Cilji raziskave $\quad 130$

Rezultati in razprava 133

Motivacija, tekmovalnost in samospoštovanje pri študentih različnega spola 133

Motivacija,tekmovalnostinsamospoštovanjeprištudentihrazličnihštudijskihsmeri 136

Povezanost motivacije in ostalih psiholoških dimenzij z učnim uspehom $\quad 141$

Povezanost med motivacijo, tekmovalnostjo in samospoštovanjem 143

Zaključki 145

$\begin{array}{ll}\text { Literatura } & 146\end{array}$

Marko Radovan, Sabina Jelenc Krašovec in Sonja Kump • Motivacija v izobraževanju odraslih

$\begin{array}{ll}\text { Notranji in zunanji vidiki motivacije } & 154\end{array}$

Razumevanje izobraževalnih ovir $\quad 155$

Teorija samoodločanja $\quad 156$

Teorija samoregulacijskega učenja $\quad 157$

Osebni izobraževalni načrt in andragoška teorija 159 


\begin{tabular}{|c|c|}
\hline Samostojno učenje odraslih & 160 \\
\hline Osebni izobraževalni načrt kot učna metoda ali učni pripomoček & 161 \\
\hline Zakonske podlage za Osebni izobraževalni načrt & 162 \\
\hline Raziskovalni cilji & 163 \\
\hline Opis raziskave & 163 \\
\hline Rezultati in razprava & 166 \\
\hline Načrtovanje osebnih izobraževalnih načrtov & 166 \\
\hline Upoštevanje določbe zakona o strokovnem in poklicnem izobraževanju & 166 \\
\hline Uvodni razgovor z udeleženci izobraževanja odraslih & 168 \\
\hline Priznavanje predhodno pridobljenih znanj & 170 \\
\hline Oblikovanje in izvedba osebnih izobraževalnih načrtov & 170 \\
\hline $\begin{array}{l}\text { Priprava osebnega izobraževalnega načrta v izobraževalnih programih } \\
\text { srednjega poklicnega in strokovnega izobraževanja za odrasle }\end{array}$ & 170 \\
\hline $\begin{array}{l}\text { Vpliv udeležencev poklicnega in strokovnega izobraževanja odraslih } \\
\text { na vsebino osebnega izobraževalnega načrta }\end{array}$ & 174 \\
\hline $\begin{array}{l}\text { Informiranost učiteljev o osebnih izobraževalnih načrtih udeležencev } \\
\text { in njihovo sodelovanje pri uresničevanju osebnega izobraževalnega načrta } \\
\text { posameznika }\end{array}$ & 175 \\
\hline Vpliv osebnega izobraževalnega načrta na izvajanje izobraževalnega programa & 177 \\
\hline $\begin{array}{l}\text { Prilagajanje programa izobraževanja posamezniku glede na njegov osebni } \\
\text { izobraževalni načrt }\end{array}$ & 177 \\
\hline $\begin{array}{l}\text { Vloga in pomen osebnega izobraževalnega načrta za kakovost izobraževalneg } \\
\text { procesa }\end{array}$ & 178 \\
\hline Osebni izobraževalni načrt kot motivacijsko sredstvo & 180 \\
\hline $\begin{array}{l}\text { Razumevanje osebnega izobraževalnega načrta kot motivacijskega sredstva } \\
\text { za udeležence in izvajalce izobraževanja odraslih }\end{array}$ & 180 \\
\hline Vpliv osebnega izobraževalnega načrta na uspešnost odraslih pri učenju & 183 \\
\hline Ovire, s katerimi se soočajo udeleženci izobraževanja odraslih & 184 \\
\hline Ovrednotenje uresničevanja osebnih izobraževalnih načrtov & 186 \\
\hline
\end{tabular}


Težave in ovire organizatorjev izobraževanja pri uresničevanju osebnega izobraževalnega načrta

Predlogi organizatorjev izobraževanja glede osebnih izobraževalnih načrtov 188

Sklepne ugotovitve in predlogi 190

Literatura 197

Povzetek 201

Summary 205

Imensko in stvarno kazalo

209 



\section{Kazalo tabel}

Tabela 1: Izhodišča merjenja znotraj vprašalnikov

Tabela 2: Odstotek odgovorov na vprašanje: Približno koliko časa navadno nameniš branju za zabavo?

Tabela 3: Odstotek dijakov, ki so na posamezne trditve odgovarjali s »Strinjam se« in »Popolnoma se strinjam《

Tabela 4: Odstotek dijakov, ki berejo bralno gradivo »večkrat na mesec« ali »večkrat na teden«

Tabela 5: Odstotek dijakov, ki berejo različne kombinacije bralnih gradiv »večkrat na mesec« ali »večkrat na teden«, ter njihovi povprečni bralni dosežki

Tabela 6: Odstotek dijakov, ki se ukvarjajo z različnimi bralnimi aktivnostmi na spletu »večkrat na teden« ali »večkrat na dan«

Tabela 7: Odstotek dijakov, ki so na trditve o disciplini pri pouku materinščine odgovorili z »Nikoli ali zelo redko《 in »Pri nekaterih urah«

Tabela 8: Odstotek dijakov, ki so na trditve o spodbudi s strani učitelja odgovorili s »Pri večini ur« in »Pri vseh urah«

Tabela 9: Odstotek dijakov, ki so na trditve o transparentnosti učnega procesa in ocenjevanja odgovorili s »Pri večini ur« in »Pri vseh urah«

Tabela 10: Odstotek dijakov, ki so na trditve o odnosu učiteljev do njih odgovorili s »Strinjam se« in »Popolnoma se strinjam《 
Tabela 11: Primerjava pogostosti posameznih kategorij pri dijakih z različnimi ravnmi dosežkov na testu bralne pismenosti pri različnih nominalnih spremenljivkah in median pri ordinalnih spremenljivkah

Tabela 12: Povprečne vrednosti indeksov v surovi, nestandardizirani obliki, $\checkmark$ različnih skupinah dijakov 83

Tabela 13: Struktura dijakov glede na izobraževalni program 85

Tabela 14: Primerjava dijakinj in dijakov po dosežkih na testu bralne pismenosti 97 Tabela 15: Primerjava odstotkov posameznih skupin bralcev pri dijakinjah in dijakih 99 Tabela 16: Informiranostučiteljev ovlogi in pomenu osebnegaizobraževalneganačrta $\mathbf{1 7 6}$ Tabela 17: Pogostost razgovorov z udeleženci izobraževanja odraslih glede osebnih izobraževalnih načrtov 


\section{Kazalo slik}

Slika 1: Razlike med dijakizrazličnimi ravnmi dosežkov po posameznihspremenljivkah 76 Slika 2: Povprečni splošni dosežek na testu bralne pismenosti in povprečni dosežki pri posameznem vidiku bralnega procesa pri dijakih, uvrščenih na določeno raven bralne pismenosti

Slika 3: Povprečne standardizirane vrednosti posameznih indeksov v petih skupinah dijakov

Slika 4: Dosežki na testu bralne pismenosti v petih skupinah dijakov: povprečen skupen dosežek na testu in povprečni dosežki pri posameznih vidikih bralnega procesa $\quad \mathbf{8 4}_{4}$

Slika 5: Delež žensk in moških v posameznih izobraževalnih programih 88

Slika 6: Aritmetična sredina in 95-odstotni interval zaupanja za aritmetično sredino skupnega dosežka in dosežkov na posameznih podlestvicah na testu PISA 2009 pri dijakih $v$ različnih izobraževalnih programih

Slika 7: Primerjava skupnega dosežka različnih skupin bralcev iz različnih izobraževalnih programov $\quad 96$

Slika 8: Primerjava skupnega dosežka dijakinj in dijakov iz različnih skupin bralcev 99 Slika 9: Razlike med spoloma na različnih področjih motivacije za izobraževanje 133 Slika 10: Razlike med spoloma v motivaciji za tekmovalnost

Slika 11: Razlike med spoloma $\vee$ zadovoljenosti temeljnih psihičnih potreb ter pogojenosti in nestabilnosti samospoštovanja 
Slika 12: Razlike med študenti družboslovja in humanistike ter naravoslovja in tehnike na različnih področjih motivacije za izobraževanje

Slika 13: Razlike med študenti družboslovja in humanistike ter naravoslovja in tehnike $v$ okviru motivacije za tekmovalnost

Slika 14: Razlike med študenti družboslovja in humanistike ter naravoslovja in tehnike $v$ zadovoljenosti temeljnih psihičnih potreb, dimenzijah in pogojenosti samospoštovanja ter pozitivni emocionalnosti

Slika 15: Socialno-kognitivni model samoregulacijskega učenja $15^{8}$ 


\section{Predgovor}

Pričujoča monografija je nastala v sodelovanju strokovnjakov s področja psihologije in andragogike, ki smo svoje raziskovalne moči združili v evalvacijski študiji z naslovom Motivacijski dejavniki v izobraževanju mladine in odraslih. Študijo je finančno podprlo Ministrstvo za izobraževanje, znanost in šport in se je izvajala v letih 2010-20I 2.

V evalvacijski študiji smo izvedli tri neodvisne raziskave. Vsem raziskavam je skupna obravnava značilnosti motivacije v izobraževanju, vendar se vsaka študija osredotoča na specifične vidike motivacije in v različnih razvojnih oz. učnih obdobjih. V študiji z naslovom Motivacijski dejavniki bralnih dosežkov v raziskavi PISA 2009 smo raziskovalke Melita Puklek Levpušček, Anja Podlesek in Klaudija Šterman Ivančič analizirale podatke, zbrane v raziskavi bralne pismenosti PISA 2009, v kateri so sodelovali I5-letniki iz držav OECD in držav partneric. Analizirale smo področje bralnih aktivnosti, motivacije za branje, učnih strategij ter značilnosti učnega okolja. Rezultate slovenskih I5-letnikov smo pri omenjenih dejavnikih bralne pismenosti primerjale $\mathrm{z}$ rezultati njihovih vrstnikov v dveh visoko uspešnih evropskih državah (Finska in Norveška). Slovenski is-letniki so se v primerjavi z vrstniki iz skandinavskih držav izkazali kot manj raznovrstni bralci ter kot bralci, ki berejo najmanj leposlovja, predvsem zaradi zunanje motivacije (ker morajo oz. da dobijo potrebne informacije). Omenjeni rezultati kažejo, da je v slovenskih šolah treba v večji meri krepiti notranje zanimanje za branje, tudi z izbiro primernega bralnega gradiva in z novimi pristopi k obravnavi prebranega. Vsekakor pa je razveseljivo dejstvo, da slovenski mladostniki nadpovprečno (tudi v primerjavi s finskimi in norveškimi vrstniki) pozitivno ocenjujejo spodbude učitelja slovenščine k zavzetosti in aktivni udeležbi pri branju. Nadalje smo avtorice ugotavljale tipične bralne profile slovenskih I5-letnikov. Podobno kot v predhodnjih analizah se je pokazalo, da med 15 -letniki prevladujejo profili nezavze- 
tih bralcev (60\%), ki pa imajo v različni meri razvite učne in metakognitivne bralne strategije. Odstotki dijakov, ki se nahajajo v posameznem profilu, variirajo glede na izobraževalni program in spol dijakov. V splošnem so rezultati študije pokazali, da bi v slovenskem izobraževanju veljalo okrepiti socialni kontekst branja v mladostniškem obdobju. Pri pouku je treba spodbujati več razprav o prebranem, ne le na ravni učitelj - posamezen učenec, ampak tudi z vrstniškim delom v skupini. Prav tako bi povezovanje učenja z uporabo informacijsko-komunikacijske tehnologije (IKT) pri pouku in doma verjetno ugodno učinkovalo na poskus povečanja motivacije za branje, zlasti pri fantih. Naslednjo raziskavo z naslovom Povezanost med motivacijo za izobraževanje, tekmovalnostjo in različnimi področji samopodobe pri študentih so izvedli Darja Kobal Grum, Janez Kolenc in Manca Seničar. V njej so se ukvarjali z različnimi vidiki motivacije pri študentih. Zanimalo jih je, kako se različni vidiki motivacije za izobraževanje in motivacije za tekmovanje ter vidiki samospoštovanja razlikujejo po spolu, študijski usmeritvi in študijskem uspehu študentov. Študentke so tako v večji meri kot študentje notranje motivirane za študij, izberejo študij v skladu s svojimi zanimanji, pri tem sledijo tudi zunanjim kriterijem, vendar se z njimi poistovetijo, kažejo manj izraženo željo po zmagi in več zadovoljstva ob izboljšanju lastnih sposobnosti ter dobro opravljeni nalogi. Glede na različne študijske usmeritve avtorji ugotavljajo, da družboslovci v večji meri kot naravoslovci kažejo notranjo motivacijo za študij, sledijo tudi zunanjim ciljem, vendar se z njimi poistovetijo, vedo, zakaj so se odločili za nek študij in imajo bolj izoblikovane cilje, so manj hipertekmovalni, vendar bolj tekmovalni v smislu izboljšanja lastnih sposobnosti in dobro opravljenih nalog. Ugotovitve raziskave poudarjajo pomen spodbujanja notranje motivacije za študij in tekmovalnosti predvsem v smislu osebnega razvoja posameznika. V tretji študiji z naslovom Motivacija v izobraževanju odraslih so se avtorji Marko Radovan, Sabina Jelenc Krašovec in Sonja Kump ukvarjali z motivacijo odraslih, ki so v procesu izobraževanja. Zanimalo jih je, v kolikšni meri se pri izvajanju strokovnega in poklicnega izobraževanja odraslih upoštevajo navodila o prilagajanju izrednega poklicnega in strokovnega izobraževanja, ki so opredeljena v Zakonu o poklicnem in strokovnem izobraževanju. Podrobneje so se ukvarjali z vlogo osebnega izobraževalnega načrta (OIN) pri motiviranju odraslih za izobraževanje in zagotavljanju njihovega uspešnejšega dokončanja študija. V raziskavi so sodelovali organizatorji izobraževanja in odrasli udeleženci izobraževanja. Rezultati so pokazali razhajanje v percepciji uporabe in koristnosti OIN. Za kar polovico organizatorjev izobraževanja priprava in izvajanje OIN ne predstavlja motivacijskega sredstva, ampak težavo. Večino odraslih udeležencev izobraževanja pa OIN ne motivira. Avtorji ugotavljajo, da je OIN 
lahko uporabno motivacijsko sredstvo izobraževanja odraslih, ki pa v sedanji izobraževalni praksi še ni dovolj izkoriščeno.

Monografija je namenjena strokovnjakom različnih profilov, ki se pri svojem delu srečujejo $\mathrm{z}$ učenjem in poučevanjem udeležencev izobraževanja na različnih starostnih stopnjah. Motivacija je ena izmed temeljnih gonilnih sil učenja in učne uspešnosti, vsekakor pa je tudi socialni kontekst tisti, ki jo določa, krepi/slabi in usmerja. Vredno je zato razmišljati, kako z ukrepi, kot so aktivni načini poučevanja, vrstniško učenje, primerna izbira učnega gradiva, individualizacija pouka, prilagajanje izobraževanja potrebam mladine in odraslih itd. spodbujati pristno zanimanje za učenje in doživljanje učenja kot nečesa prijetnega in izpopolnjujočega.

\section{Urednici}





\title{
Motivacijski dejavniki bralnih dosežkov v raziskavi PISA 2009
}

\author{
Melita Puklek Levpušček,' Anja Podlesek' \\ in Klaudija Šterman Ivančičč
}

\section{Motivacija za branje}

Motivacija za branje je v zadnjih dveh desetletjih pogost predmet proučevanja strokovnjakov z različnih področij, še posebej bralne pismenosti. V strokovni literaturi je zaslediti opredelitve bralne motivacije predvsem $\mathrm{v}$ smislu večdimenzionalnega konstrukta, ki zajema elemente teorije pripisovanja, koncept samoučinkovitosti, bralne identitete, situacijskega in motivacijskega interesa, vrednotenja branja, odnosa do branja, samousmerjanja ter samoregulacije bralnega procesa, njene dimenzije pa so največkrat opredeljene z vidika zunanje in notranje motivacije (Meltzer in Hamann, 2004).

Guthrie in Wigfield, ki ju štejemo med najpomembnejše sodobne avtorje s področja bralne motivacije, opredeljujeta motivacijo za branje kot večdimenzionalen konstrukt, ki zajema niz ciljev in prepričanj, ki vodijo bralno vedenje posameznika in so med seboj v večini pozitivno povezani. Nadalje menita, da gre za interakcijo med posameznikovimi osebnimi cilji, vrednotami in prepričanji, ki se navezujejo na različne teme, procese ter rezultate branja (Guthrie in Wigfield, 1997). Tudi S. Pečjak (2010) v našem prostoru opredeljuje bralno motivacijo kot »nadpomenko za različne motivacijske dejavnike, ki spodbujajo človeka $\mathrm{k}$ branju, dajejo bralnemu procesu smisel in tako pomagajo posamezniku, da vztraja do cilja in si želi bralno izkušnjo še ponoviti (ponovno doživeti).«

Raziskovalci navajajo različne motivacijske elemente bralne pismenosti. L. Baker in D. Scher (v Pečjak, 20Io) menita, da konstrukt bralne motivacije zajema posameznikov interes za branje, njegov odnos do branja, zaznavo lastne bralne kompetentnosti ter vrednotenje različnih bralnih dejavnosti. Csikszentmihalyi (v Pečjak et al., 2006) pa opredelju-

I Univerza v Ljubljani, Filozofska fakulteta, Oddelek za psihologijo

2 Pedagoški inštitut v Ljubljani 
je bralno motivacijo s tokom, ki posameznika ob izkušnji, ki jo rad počne, prevzame, kot pogoj pa mora posameznik doživljati, da je tej izkušnji kos. Ob tem poudarja, da bo v nasprotnem primeru posameznik postal tesnoben in se bo situaciji skušal izogniti. Bralno motivacijo po njegovem mnenju podpirajo sovpadanje izziva in sposobnosti, jasen cilj in takojšnja povratna informacija. Guthrie in Wigfield (v Pečjak, 20 Io), ki govorita o dimenzijah bralne motivacije, le-te združujeta v naslednje kategorije:

- prepričanja o sposobnostih in učinkovitosti (kompetentnost - prepričanje posameznika, da je lahko uspešen, izziv - pripravljenost spopasti se s težkimi besedili, izogibanje aktivnosti - odločitev posameznika, da se aktivnosti izogne),

- cilji in razlogi za branje (notranji - radovednost, zatopljenost; zunanji - priznanje in tekmovalnost) ter

- socialni vidik branja (socialnost in ustrežljivost).

S. Pečjak (2oro) ob ugotovitvah številnih avtorjev, ki kažejo na to, da je motivacija za branje večdimenzionalna in raznolika, poudarja, da glede na to ne moremo govoriti o motiviranih in nemotiviranih učencih, temveč le o motiviranih učencih na različne načine in za različne bralne vsebine.

S. Pečjak, N. Bucik, A. Gradišar in C. Peklaj (Pečjak et al., 2006) so povzele ugotovitve omenjenih avtorjev in dejavnike bralne motivacije razvrstile glede na notranjo ter zunanjo motiviranost posameznika. Notranjo motivacijo za branje tako opredeljuje:

- kompetentnost (zaupanje v lastne bralne zmožnosti, prepričanje posamezni-

ka, da lahko izpelje bralne naloge do konca);

- interes (vztrajanje in čustvena vključenost bralca, usmerjena pozornost);

- zatopljenost učenca $\mathrm{v}$ branje (osredotočenost na gradivo s povečano miselno aktivnostjo);

- prepričanje bralca o pomembnosti branja.

V zunanjo motivacijo za branje pa so avtorice uvrstile naslednje prvine:

- priznanje, dosežek (branje z namenom dobiti dobro oceno, pohvalo);

- tekmovanje z drugimi (branje z namenom biti boljši od sovrstnikov);

- $\quad$ socialno motivacijo (posameznik bere zato, da lahko sodeluje $\mathrm{v}$ pogovoru $\mathrm{s}$ prijatelji ipd.).

Notranje motiviranega bralca branje povsem prevzame, vanj je zatopljen, uporablja kompleksnejše strategije razumevanja in učenja, ima raznolike interese, si sam postavlja 
bralne cilje in glede na njih usmerja trud ter premaguje ovire, rad deli izkušnje s sošolci in pokaže, kaj zna, nagrada je zanj novo znanje, ki mu predstavlja užitek ter vir zadovoljstva, svoje branje pa ceni in ima do njega pozitivna stališča. V nasprotju s tem se zunanje motiviran učenec branju izogiba in bere le, ko je $\mathrm{v}$ to primoran, učinkovitih strategij ne pozna in se izogiba njihovi uporabi, je ustrežljiv in prilagodljiv, bralne cilje mu postavljajo drugi, išče najkrajšo pot do cilja, o prebranem ne govori rad in o svojem branju nima dobrega mnenja, do branja ima manj pozitivna stališča, branje pa mu predstavlja dosego drugih ciljev (Pečjak in Gradišar, 2002).

Zanimivi so tudi izsledki raziskave, ki jo je izvedla L. Gambrell (v Pečjak in Gradišar, 2002). Osnovnošolske učence je spraševala o tem, kaj v šolskem okolju je tisto, kar jih motivira pri branju. Kot najpomembnejše motivacijske vplive so učenci navedli učitelja, v smislu dobrega bralnega modela (učitelj tudi sam veliko bere, bere učencem, se o vsebinah z njimi pogovarja itd.), razredno knjižnico (dostopnost gradiva), možnost izbire (kar povečuje učenčevo avtonomijo in neodvisnost pri branju), pogovore in druženja, povezana s knjigami, prejšnje izkušnje, povezane s knjigami in vsebinami (mlade zanimajo znane, domače knjige, saj spodbujajo vedoželjnost), ter bralne spodbude s strani učitelja.

Ob bralni motivaciji pa se v strokovni literaturi pogosto pojavlja tudi pojem bralna zavzetost oz. angažiranost (ang. reading engagement). Guthrie in sodelavci (v Pečjak et al., 2006) opredeljujejo bralno zavzetega bralca kot notranje motiviranega, tistega, ki gradi in povezuje znanje s pomočjo širjenja pojmov, uporabe kognitivnih strategij in sodelovanja z drugimi.

Tudi v raziskavi PISA 2009 govorimo v okviru bralne motivacije o t. i. bralni zavzetosti, ki temelji na konceptu teorije samodoločenosti. Zavzet bralec je znotraj omenjenega koncepta tisti, ki je notranje motiviran, tj. tisti, ki bere, ker ga branje privlači in branje tudi pozitivno vrednoti. Tak bralec nosi v sebi prepričanja, cilje in vrednote, zaradi katerih se udejstvuje v različnih bralnih aktivnostih in uspešno dosega zastavljene izobraževalne, poklicne, osebne ter socialne cilje.

Bralna zavzetost se znotraj koncepta raziskave PISA nanaša na motivacijske in vedenjske vidike posameznikovega branja. Tako vključuje interes za branje, avtonomijo pri branju in socialno interakcijo ter pogostost in raznovrstnost branja. Zavzetega bralca v tem pogledu opredeljujejo dobro izoblikovan interes za branje, raznovrstne teme branja in tipi bralnega gradiva (interes za branje), zavzeti bralci berejo samoiniciativno in nadzorujejo svoj proces branja (avtonomnost), s pomočjo socialnega okolja širijo svoje bralne kompetence in delijo svoje znanje in izkušnje z drugimi (socialni vidik) ter berejo pogosto in po- 
segajo po raznovrstnih besedilih (bralno vedenje). Znotraj raziskave so ti štirje vidiki podrobneje opredeljeni na naslednji način:

- $\quad$ interes za branje: branje literature ali informativnih besedil zaradi uživanja $\mathrm{v}$ branju, osebnega zadovoljstva ter radovednosti;

- zaznana avtonomija: zaznana kontrola in samousmerjanje pri bralnih aktivnostih, izbiri bralnega gradiva in bralnem vedenju;

- $\quad$ socialna interakcija: posameznikovi socialni cilji, ki se navezujejo na branje ter njegove kompetence interakcije;

- bralna praksa: zavzetost, ki se navezuje na količino in tip bralne aktivnosti (OECD, 2009).

Dijaki, ki izkazujejo najnižjo stopnjo bralne zavzetosti, so znotraj raziskave PISA opredeljeni kot tisti, ki berejo zelo malo zaradi lastnega zadovoljstva in interesa, imajo ozek izbor besedil in niso motivirani za samostojno branje ali branje v socialnem kontekstu. Nasprotno pa zelo zavzeti bralci berejo raznovrstne tipe besedil, tako elektronskih kot tiskanih, branju pa poleg tega, da ga vrednotijo pozitivno, pripisujejo tudi pomembno vlogo pri njihovih socialnih interakcijah.

Študije, v katerih so raziskovalci ugotavljali povezanost bralne motivacije in pripadajočih dimenzij z bralno pismenostjo ter bralnimi učnimi dosežki, so v večini primerov skladne $\mathrm{v}$ ugotovitvi, da se bralna motivacija pomembno pozitivno povezuje tako $\mathrm{z}$ bralnimi učnimi dosežki kot z bralno pismenostjo (Baker in Wigfield, 1999; Pečjak et al., 2006; Wigfield in Guthrie, 1997). Baker je s sodelavci (1999) izvedel longitudinalno študijo, v kateri so ugotavljali povezanost notranje in zunanje motivacije $\mathrm{z}$ bralno pismenostjo pri učencih četrtega razreda, meritve pa so nato ponovili čez dve leti, na istih učencih. Ugotovili so, da so učenci, ki so bili notranje motivirani za branje v četrtem razredu, $\mathrm{v}$ šestem razredu izkazovali višjo stopnjo bralne pismenosti kot učenci, ki so bili zunanje motivirani. Pri tem se je kot pomembna mediatorska spremenljivka pokazal čas, namenjen branju. Torej, učenci, ki dojemajo branje kot zanimivo in prijetno aktivnost, tudi berejo več, kar pa povečuje njihove bralne kompetence.

Rezultati raziskave PISA 2000, kjer je bilo branje poudarjeno področje merjenja, so pokazali podobne rezultate, in sicer se je v vseh sodelujočih državah pri 15 -letnikih pokazala dokaj močna pozitivna povezanost med notranjo motivacijo za branje v smislu bralne zavzetosti ter dosežki na testu bralne pismenosti. Ta povezanost se je celo izkazala kot močnejša od povezanosti med bralnimi dosežki ter socialno-ekonomskim ozadjem dija- 
kov, kar po mnenju strokovnjakov kaže na pomembno vlogo spodbujanja bralne motiviranosti učencev pri zmanjševanju razlik v dosežkih dijakov znotraj posameznih držav kot tudi zmanjševanju razlik v dosežkih med spoloma. Rezultati so namreč pokazali tudi, da so dekleta veliko bolj motivirana za branje kot fantje ter posledično tudi izkazujejo višje dosežke na testu bralne pismenosti (OECD, 2009).

Pri proučevanju motivacijskih dejavnikov bralne uspešnosti v slovenskem prostoru so avtorice raziskave (Pečjak et al., 2006), ki je vključevala učence 3. in 7. razreda osnovne šole $(\mathrm{N}=2355)$, ugotovile, da med motivacijskimi dejavniki, ki se pomembno pozitivno povezujejo z bralno uspešnostjo, izstopata interes za branje ter pojmovanje pomembnosti branja. Avtorice so ugotovile, da prihaja pri omenjenih prvinah bralne motivacije do pomembnih razlik po spolu, saj so se dekleta izkazala kot pomembno bolj motivirana za branje kot fantje, ne glede na starost. Hkrati pa so pri obeh spolih avtorice zaznale trend upadanja notranje motivacije s starostjo, pri čemer je bil upad pri fantih ponovno bolj izrazit. Ugotovile so tudi pozitivno povezanost med zatopljenostjo v branje in bralno učinkovitostjo. Fantje in dekleta, ki so bolj zatopljeni v branje, so tudi bolj učinkoviti pri branju. Ponovno pa se je izkazalo, da imajo to prvino notranje motivacije bolj izraženo dekleta.

Dekleta pa izkazujejo tudi višjo zunanjo motivacijo za branje, tj. željo po priznanju, dosežkih ter tekmovalnost. Razlike v zunanji motivaciji so bile ugotovljene tudi med manj in bolj uspešnimi bralci, ne glede na spol. Manj uspešni bralci so se izkazali kot pomembno manj zunanje motivirani kot dobri bralci. Rezultati omenjene slovenske raziskave so skladni z ugotovitvami tujih avtorjev, ki so v svojih raziskavah ugotovili podobne povezanosti med prvinami notranje motivacije ter bralno uspešnostjo (Cunningham in Stanovic, 1991; Guthrie in Wigfield, 2000; Wigfield, 1994) kot tudi razlike v bralni motivaciji po spolu (Baker in Wigfield, 1999; Bucik, 2003; Wigfield in Guthrie, 1997).

Mnogo avtorjev opozarja tudi na pomembnost socialnega okolja pri razvoju motivacije za branje, kamor uvrščajo odnose s sovrstniki, starši in učitelji (Guthrie in Wigfield, 2000; McCombs in Barton, 1998; Meltzer in Hamann, 2004). Ta vidik bralne pismenosti je poudarjen tudi znotraj raziskave PISA. Motivacija za branje, predvsem pa lastno odločanje za branje, se po mnenju strokovnjakov (Guthrie v OECD, 2009) najprej oblikuje v posameznikovi interakciji s pomembnimi drugimi, ki branje prav tako vrednotijo kot pomembno in pozitivno. Posameznik tako branje kot vrednoto najprej doživlja pri starših in jo kasneje tudi sam ponotranji. V takem okolju postane branje sčasoma ugoden vir mentalne stimulacije in osebnega ter čustvenega zadovoljstva. Oblikovanje lastnega odločanja pri branju je tako v veliki meri odvisno od opore s strani najbližjih. Ugodno okolje zago- 
tavlja razvoj bralnih kompetenc in širi avtonomijo posameznika pri vodenju in usmerjanju lastnega bralnega procesa.

Tudi S. Pečjak in A. Gradišar (Pečjak in Gradišar, 2002) poudarjata pomen zgodnjega otroštva pri razvoju bralne motivacije. Otrokov odnos do branja in bralni interesi se oblikujejo že v predšolski dobi, na temelju izkušenj posrednega branja. Pozitivna stališča pa nastopajo kot olajševalni dejavnik ob poznejših morebitnih težavah. Ob tem poudarjata, da se slabe izkušnje z leti kopičijo in znižujejo pozitivna stališča do branja. Knaflič (v Pečjak in Gradišar, 2002) prav tako meni, da je za razvoj bralne motivacije izrednega pomena prvi razred, saj se razlike med dobrimi in slabimi bralci z leti povečujejo, spodbujanje branja pa je tako v domačem kot v šolskem okolju tudi v času mladostništva izrednega pomena.

Ugodnega socialnega okolja pa ne predstavlja le družina in ostali pomembni drugi, temveč ima pomembno vlogo pri oblikovanju lastnega odločanja za branje tudi šola ter šolska in razredna klima. Če domače in šolsko okolje pri posamezniku spodbujata samozavest pri branju in avtonomijo, bo posameznikova notranja motivacija vse višja. Učitelj ima pri tem pomembno vlogo. Raziskave kažejo (Guthrie v OECD, 2009), da posamezniki, pri katerih učitelj spodbuja zaznavo lastne kompetentnosti in nadzora nad branjem, prej postanejo aktivni bralci in dosegajo tudi višje bralne dosežke. Alverman (v Meltzer in Hamann, 2004) to povzema na naslednji način: mladostnikova zaznava tega, kako kompetenten je kot bralec, bo vplivala na njegovo motivacijo na tem področju. Torej: da bo poučevanje branja učinkovito, mora učitelj upoštevati morebitne težave $\mathrm{z}$ zaznano samoučinkovitostjo ter zavzetostjo pri učencih.

Cambournov model za spodbujanje bralnih navad pri učencih s strani učitelja (v Pečjak in Gradišar, 2002) predlaga naslednje dejavnosti v razredu, ki naj bi služile kot temelj razvoja notranje motivacije za branje:

- vzdušje v razredu, ki omogoča zatopljenost v branje,

- razpoložljivost gradiva,

- prikazovanje pomena branja (vloga učitelja kot modela v razredu),

- izražanje zaupanja $\mathrm{v}$ učenčeve sposobnosti, realna pričakovanja in cilji,

- $\quad$ spodbujanje razvoja lastne odgovornosti za napredek pri branju,

- uporabnost branja in sledenje ciljem bralne pismenosti ter

- povratna informacija o napredku pri branju, ki naj učencem pomaga pri načrtovanju branja in postavljanju novih ciljev. 
Mnogo avtorjev opozarja na upad notranje motivacije za branje v višjih razredih osnovne šole ter na prehodu v srednjo šolo (Irvin in Mullins, 2000; Wigfield, 1994). Še več, upadu notranje motivacije ponavadi sledi porast zunanje motivacije. Razloge za to avtorji iščejo v upadu prepričanj glede lastne kompetentnosti in uspeha ter vedno večjo povezanost teh prepričanj s prejšnjimi izkušnjami uspeha ali poraza. S starostjo učencev se torej povečuje tudi pomembnost zaznanega uspeha ali neuspeha pri različnih učnih nalogah, tudi bralnih. V primeru uspeha se prepričanja učencev o lastni kompetentnosti in bodočem uspehu povečajo, v primeru neuspeha pa upadejo, kar pa se odraža v njihovi zavzetosti za branje in bralnih aktivnostih.

Naslednji razlog za upad notranje motivacije pa zgoraj navedeni avtorji vidijo v spremembi učnega in socialnega okolja na prehodu iz osnovne v srednjo šolo. V primerjavi z osnovno šolo se med mladostniki v srednji šoli poveča medsebojna primerjava, tekmovalnost, pa tudi pomen vrednotenja $v$ učnih situacijah. Srednje šole so v primerjavi z osnovnimi tudi večje, kar predstavlja širše okolje za socialno primerjavo, v katerem si vsak posameznik še težje izbori svoj prostor. Za mladostnike, ki so v tem obdobju v procesu izoblikovanja lastne identitete, to ni lahka naloga. $\mathrm{V}$ tem obdobju pogosto potrebujejo oporo in spodbudo pri pozitivni samooceni lastnih kompetenc, kar pa je ob poudarjanju visokih dosežkov in pomena ocenjevanja pogosto zanemarjeno. Srednješolsko okolje zaradi omenjenih dejavnikov tako pogosteje prispeva $\mathrm{k}$ upadu pozitivnih prepričanj o lastni kompetentnosti in uspehu. Guthrie (2000) tako opozarja na izreden pomen ustvarjanja razredne klime, ki spodbuja pozitivna prepričanja v lastno samoučinkovitost.

Tudi raziskava v slovenskem prostoru (Pečjak et al., 2006) je pokazala na upad zaznane bralne kompetentnosti že v višjih razredih osnovne šole, še posebej pri fantih. Ob primerjavi učencev tretjega in sedmega razreda so avtorice raziskave ugotovile, da v tretjem razredu še ne prihaja do večjih razlik v prepričanjih o svojih bralnih sposobnostih, v sedmem razredu pa so te razlike že očitne. Prihaja pa tudi do pomembnih razlik med spoloma. Ker so za zaznavo lastne kompetentnosti zelo pomembne povratne informacije, ki jih učenec dobi od učiteljev, staršev in sovrstnikov, avtorice ta rezultat pripisujejo dejstvu, da so dekleta v večji meri deležna pozitivne povratne informacije kot fantje, saj pogosteje berejo besedila, ki jih določi učitelj, pa tudi berejo več. Ob tem še bolj razvijajo svoje bralne strategije in zaupajo v svoje bralne kompetence.

Meltzer in Hamann (2004) na podlagi pregleda številnih izsledkov raziskav tako navajata poglavitne elemente učnega okolja, ki jih je treba upoštevati, če želimo krepiti notranjo motivacijo mladostnikov za branje: 
- povezovanje vsebine z življenjskimi situacijami mladostnikov in njihovim preteklim znanjem;

- ustvarjanje klime, kjer lahko vsak posameznik izrazi svoje mnenje ter prispeva $\mathrm{k}$ izbiri gradiva ter

- ustvarjanje klime, kjer se mladostniki o prebranem pogovarjajo, sprašujejo, predvidevajo, vizualizirajo in prebrano povzemajo.

\section{Učne in metakognitiune strategije}

Učinkovito učenje predpostavlja, da učenci zavzemajo aktivno vlogo v procesu poučevanja in učenja. Aktivno vlogo pa lahko prevzemajo le, če imajo znanje o tem, kako se učiti, kako učenje organizirati in ob tem upoštevati lastne specifične lastnosti ter lastnosti učnega konteksta (Pečjak in Gradišar, 2002). Vse to pa zajema področje učnih strategij. Učne strategije so v strokovni literaturi s področja ugotavljanja različnih dejavnikov učne uspešnosti pogosto opredeljene kot ključna komponenta koncepta samoregulacije oz. učne samoregulacije (Pintrich in De Groot, 1990; Zimmerman, 1990).

$\mathrm{V}$ teoriji še vedno ni enotne opredelitve samoregulativnega učenja. Cleary in Zimmerman (2004) samoregulativno učenje opredeljujeta kot učenje, pri katerem si učenec sam postavlja učne cilje, proces učenja spremlja, kontrolira in regulira, tako pred in med kot po samem učnem procesu (samorefleksija). V tem procesu je učenec metakognitivno, vedenjsko in motivacijsko aktivno udeležen. $Z$ drugimi besedami, učne strategije in njihova učinkovita uporaba so pomemben del učnega procesa, ki so skupaj z drugimi kognitivnimi (npr. védenje in prepričanje o učenju, pojmovanja učenja), metakognitivnimi, motivacijskimi in čustvenimi procesi ter interakcijo med njimi pogoj za razvoj t. i. učne samoregulacije pri posamezniku, kar pa med drugim vodi tudi v doseganje višjih učnih dosežkov na različnih testih znanja. Tudi v raziskavi PISA 2000, se je, ko je bilo poudarjeno področje merjenja branje, učinkovita uporaba učnih in metakognitivnih strategij skupaj z motivacijskimi dejavniki (zavzetost za branje, interes itd.) izkazala kot pomemben prediktor učne uspešnosti na testu branja. I5-letniki iz vseh udeleženih držav, ki so poročali o zavedanju koristnosti učnih strategij in njihovi pogosti ter raznoliki uporabi v različnih učnih situacijah, so na testu bralne pismenosti dosegali tudi višje rezultate (OECD, 2009).

B. Marentič Požarnik (2000) v splošnem opredeljuje učne strategije kot »zaporedje ali kombinacijo v cilj usmerjenih učnih aktivnosti, ki jih posameznik uporablja na svojo pobudo in spreminja glede na zahteve situacije«. Za razvoj učinkovite učne samoregulacije pa so pomembne tako kognitivne kot metakognitivne strategije. M. Boekaerts (1996) 
meni, da gre pri kognitivnih strategijah za različne kognitivne procese in vedenja, ki jih posameznik uporablja za dosego učnega cilja. Ob tem opozarja, da so kognitivne strategije lahko zavestne in jih učenec nadzira, lahko pa gre tudi za avtomatično uporabo in jih učenec uporablja nezavedno.

Weinstein in Mayer (v Lončarič in Peklaj, 2008) opredeljujeta kognitivne strategije s pomočjo naslednjih treh sklopov, ki so po njunem mnenju pomembni za šolsko uspešnost: ponavljanje, elaboracijske in organizacijske strategije. Strategije ponavljanja učencu omogočajo, da iz učnega gradiva razbere določene informacije in jih obdrži v delovnem spominu, kar je pomembno za samo zapomnitev podatkov. Pri tej vrsti strategij gre lahko tudi za klasifikacijo informacij, razvrščanje ipd. Pri elaboracijskih strategijah pa ne gre le za načine zapomnitve določene informacije - tukaj učenec informacije že parafrazira, povzema, se o naučenem sprašuje ali oblikuje analogije. $\mathrm{Na}$ ta način informacije na nek način preoblikuje in vzpostavi odnose med njimi. Pri teh strategijah gre že za globlje razumevanje in jih zato uvrščamo med strategije globljega procesiranja. Sem pa uvrščamo tudi organizacijske strategije. Pri teh gre za iskanje bistva, pomembne ideje, organizacijo najpomembnejših pojmov $\mathrm{v}$ učnem gradivu ter iskanje podobnosti in razlik med določenimi deli besedila. Mednje uvrščamo tudi miselne vzorce in pojmovne mreže. S pomočjo teh strategij učenci naučeno lažje vključijo v svojo miselno strukturo.

Flavell (1979), ki ga štejemo med utemeljitelje raziskovanja metakognicije, v eni prvih opredelitev le-to opredeljuje kot znanje in razmišljanje o kognitivnih pojavih oz. razmišljanje o lastnem mišljenju. V svojem modelu kognitivnega nadzora opisuje, da metakognicija predstavlja interakcijo med metakognitivnim znanjem (kaj že znam in kaj potrebujem, da bom uspešno rešil nalogo), metakognitivno izkušnjo (izkušnja o trenutnem kognitivnem ali čustvenem stanju), ciljem oz. zastavljeno nalogo ter metakognitivno strategijo (strategije za uspešno dokončanje naloge). Kluwe (v Peklaj, 200o) nadalje opredeljuje naslednji dve temeljni značilnosti, ki veljata za metakognitivne aktivnosti: znanje o lastnem mišljenju in drugih ljudeh ter sposobnost spremljanja in uravnavanja toka lastnega mišljenja. V učni situaciji to predstavlja sposobnost načrtovanja, spremljanja, evalviranja in reflektiranja mišljenja v učnem procesu, samega procesa ter učnega izida. Učenec, ki se v proces učenja vključuje tudi na metakognitivni ravni (metakognitivni in kognitivni procesi, tj. procesiranje informacij, $v$ procesu učenja vedno potekajo vzporedno), bo razvijal strategije za načrtovanje lastnega učenja, oblikoval bo cilje in lastne kriterije uspešnosti učenja, primerne učni situaciji in nalogam, izbral bo primerne načine strukturiranja informacije ter načine za čim hitrejšo zapomnitev in predelavo informacij. 
Metakognitivne strategije delimo v tri sklope, in sicer glede na to, v kateri fazi učenja se uporabljajo. Delimo jih v strategije načrtovanja, spremljanja in uravnavanja. Strategije načrtovanja izvede učenec pred samim učenjem in z njihovo pomočjo aktivira že obstoječe znanje ter kognitivne strategije, s pomočjo katerih informacije lažje razume, jih obdela in poveže s predhodnim znanjem. Med te strategije uvrščamo postavljanje učnih ciljev, zastavljanje vprašanj pred branjem ipd. S strategijami spremljanja, ki jih učenec uporablja med samim procesom učenja, učenec ocenjuje učinkovitost uporabe različnih strategij (spremlja svoje razumevanje ter napake v razumevanju, usmerja svojo pozornost glede na učno snov ipd.). Strategije uravnavanja pa služijo refleksiji in končni oceni učnega procesa. Učenec ob koncu oceni, kaj pri reševanju določenega problema ni bilo prav in kaj bi lahko storil drugače (lahko še enkrat prebere nalogo, popravi napake itd.) (Peklaj, 2000).

Omenjene kognitivne in metakognitivne strategije so znotraj kakovostnega učnega procesa potrebne na vseh področjih posameznikovega učenja in poučevanja, še posebej na področju branja, ki na nek način predstavlja osnovo oz. temelj usvajanja znanja na vseh področjih. Znotraj branja govorimo o t. i. bralnih učnih strategijah, v teoriji pa obstajajo številne opredelitve le-teh. Tako najdemo opredelitev bralnih učnih strategij glede na časovni kriterij (strategije pred, med in po branju), glede na namen branja (strategije ponavljanja, elaboracijske in organizacijske strategije branja) ter glede na vsebino branja (strategije določanja bistva, podrobnosti, organizacije besedila, kritičnega branja, branja vidnih informacij ter strategije izboljšanja besedišča). Omenjene bralne učne strategije so po mnenju avtorjev pogoj za izboljševanje učnega procesa s strani učiteljev v smislu krepitve bralnih kompetenc pri učencih (Lewis, 1996; Weinstein in Hume, 1998).

Strategije pred branjem služijo predvsem aktiviranju predznanja učencev (npr. možganska nevihta, oblikovanje pojmovnih mrež, strategija VŽN), določitvi namena branja (kaj je cilj branja), spoznavanju zgradbe besedila (identifikacija glavnih misli ter podrobnosti in povezav med njimi), napovedovanju dogajanja oz. vsebine (oblikovanje predstave o tem, kaj se lahko pričakuje od besedila) ter zastavljanju vprašanj in oblikovanju odgovorov o besedilu. Vse to so aktivnosti pred branjem, ki bistveno pripomorejo k učinkovitemu branju in so značilnost dobrih bralcev. Branje na ta način teče bolj tekoče in obstaja večja verjetnost, da bo bralec besedilo razumel.

Med samim branjem je poseben poudarek na metakogniciji in metakognitivnih strategijah v smislu spremljanja lastnega razumevanja prebranega ter odzivanja na morebitne težave v povezavi z reševanjem zastavljenih učnih ciljev. Strategije, s pomočjo katerih lahko učitelj spodbuja spremljanje lastnega razumevanja prebranega pri učencih, so naslednje: 
dopolnjevanje manjkajočih podatkov v besedilu, določanje zaporedja dogajanja v besedilu, označevanje novih informacij, podčrtovanje bistvenih in ključnih informacij, pisanje obrobnih razlag ter zastavljanje vprašanj med branjem.

Pomemben del razumevanja besedila pa se dogaja šele po branju, saj je le razumevanje besedila za aktivno uporabo znanja premalo. Strategije po branju služijo predvsem ugotavljanju stopnje razumevanja in zapomnjenega prebranega ter urejanja vsebine v obliko, ki bo pripomogla k čim lažji zapomnitvi predelane snovi v skladu z zastavljenimi cilji. $\mathrm{Na}$ tem mestu navajamo le nekaj tovrstnih strategij: odgovarjanje na lastna poprej zastavljena vprašanja, strategije določanja bistva (iskanje bistvene ideje, povedi, sporočila), grafični prikaz pomembnih informacij (pojmovne mreže, miselni vzorci, diagram bistvo podrobnosti, zaporedje dogodkov ipd.), strategije oblikovanja učinkovitih povzetkov, kritično branje besedil, sposobnost zaključevanja itd. (več o bralnih učnih strategijah glej v Pečjak in Gradišar, 2002).

Glede na namen branja pa Weinstein in Hume (1998) ločujeta med naslednjimi bralnimi strategijami: strategije, katerih namen je zapomnitev snovi (to so bralne strategije ponavljanja - glasno obnavljanje, ponovno prebiranje, obnove, različne mnemotehnike), povezava s predznanjem (elaboracijske strategije branja - npr. povzemanje s svojimi besedami, poučevanje drugih o tej temi, analiziranje odnosov med informacijami ipd.) ter organizacijske strategije branja (združevanje podatkov v širše kategorije, odkrivanje odnosov v strukturi ...).

Tudi konceptualni okvir raziskave PISA 2009 opredeljuje bralne učne strategije v kontekstu koncepta samoregulacije, in sicer razlikuje med naslednjimi bralnimi učnimi strategijami, ki jih opredeljuje $\mathrm{v}$ smislu pristopa $\mathrm{k}$ učenju: strategije memoriranja, kontrolne strategije, strategije elaboracije, razumevanje in zapomnitev ter povzemanje besedila. V raziskavi PISA 2000 so rezultati pokazali, da so učenci, ki so brali iz užitka in ki so sami usmerjali svoj proces branja (kontrolne strategije), si zapomnili in uspešno povzemali kompleksne informacije ter vedeli, katero strategijo uporabiti pri določenem problemu, tudi dosegali višje rezultate na testu bralne pismenosti. Nasprotno pa so učenci, ki niso razvili učinkovitih strategij branja, dosegali nižje dosežke. Kot lahko razberemo, se učne strategije tesno povezujejo z motivacijskimi vidiki bralne uspešnosti (OECD, 2010a).

Raziskave, v katerih so proučevali povezanost uporabe učinkovitih strategij branja in bralnimi dosežki, kažejo, da se motivacija za branje ter bralne strategije med seboj pomembno pozitivno povezujejo. V kolikor so učenci motivirani za branje, se tudi poslužujejo kompleksnejših bralnih strategij. Prebrano skušajo povezati s svojim predhodnim zna- 
njem, skušajo razlikovati med pomembnimi in nepomembnimi informacijami v besedilu, uspešno regulirajo svoj trud, načrtujejo branje, si zastavljajo cilje ter spremljajo svoje razumevanje in napredek pri branju. Manj motivirani učenci pa se pogosto izogibajo uporabi kompleksnejših strategij, ki zahtevajo bolj poglobljeno ter kompleksno razmišljanje (Entwistle in Ramsden, 1983).

Pintrich in Schrauben (1992) sta v svojih raziskavah ugotovila pomembno povezanost med notranjo in zunanjo motivacijo ter pogostostjo uporabe bralnih strategij. Ugotovila sta, da se notranja motivacija $v$ smislu interesa za vsebino branja, učenja kot vrednote in zatopljenosti $\mathrm{v}$ bralne naloge pomembno pozitivno povezuje $s$ pogosto uporabo učinkovitih in kompleksnejših bralnih strategij. Nasprotno pa se zunanja motivacija, v smislu tekmovalnosti, izogibanja negativnemu ocenjevanju in potrebe po priznanju, dobrih ocenah ter socialnem odobravanju pomembno pozitivno povezuje z izogibanjem branju ter uporabo šibkih bralnih strategij.

\section{Raziskovalni cilji}

Cilji in koraki raziskave so bili naslednji:

I. V začetku študije smo načrtovali podroben opis in razlago rezultatov primarnih statističnih analiz PISA 2009 na področju bralnih aktivnosti, motivacije za branje, učnih strategij ter značilnosti učnega okolja, ki so del že opravljenih analiz PISA 2009. Te so predstavljene v publikacijah:

- PISA 2009 Results: What Students Know and Can Do. Student Performance in Reading, Mathematics and Science. Volume I (OECD, 2010a),

- PISA 2009 Results: Overcoming Social Background - Equity in Learning Opportunities and Outcomes (Volume II) (OECD, 201 ob),

- PISA 2009 Results: Learning to Learn - Student Engagement, Strategies and Practices (Volume III) (OECD, 2010c),

- PISA 2009 Results: What Makes a School Successful? - Resources, Policies and Practices (Volume IV) (OECD, 2010č).

$\mathrm{V}$ tej fazi raziskave smo izvedli primerjalno analizo bralnih aktivnosti, motivacije za branje, učnih strategij ter značilnosti učnega okolja. Pri omenjenih dejavnikih bralne pismenosti smo rezultate slovenskih 15 -letnikov primerjali z rezultati njihovih vrstnikov v dveh visoko uspešnih evropskih državah v raziskavi PISA 2009, tj. na Finskem in Norveškem. 
2. Ugotavljali smo tipične profile (klastre) slovenskih dijakov glede na značilnosti bralne motivacije ter učnih in metakognitivnih strategij pri branju besedil v raziskavi PISA 2009 in ugotavljali povezanost profilov z uspešnostjo na treh ravneh bralne pismenosti z vidika bralnega procesa.

3. Ugotavljali smo pomen motivacijskih dejavnikov v različnih izobraževalnih programih in po spolu. Nazadnje smo definirali tipične skupine (klastre) bralcev glede na izobraževalni program in spol in ugotavljali razlike v njihovih bralnih dosežkih.

\section{Predstavitev raziskave PISA 2009}

Raziskava PISA je mednarodni projekt, ki se izvaja od leta 2000. Slovenija se je vanj vključila leta 2004, ko so se pričele priprave na glavni zajem podatkov v letu 2006. Glavni zajem podatkov se izvaja vsake tri leta. Glavni cilj raziskave je merjenje kompetenc is-letnikov na področju naravoslovne, matematične in bralne pismenosti. V vsakem ciklu raziskave je ena od pismenosti bolj poudarjena, kar v praksi pomeni, da sta dve tretjini nalog namenjeni temu področju merjenja. Ostala tretjina nalog je namenjena proučevanju trendov. V raziskavi PISA 2009 je bilo poudarjeno področje merjenja bralna pismenost.

$S$ pomočjo raziskave PISA skušamo ugotavljati, kako dobro so mladi ob zaključku obveznega šolanja pripravljeni na izzive v sodobni družbi. Osredotočamo se na ugotavljanje sposobnosti mladih, da uporabijo znanje v resničnem življenju, in ne toliko na ugotavljanje znanj, ki si jih učenci pridobijo pri posameznih učnih predmetih in znanj, ki jih predpisuje šolski kurikulum. Torej, poglavitni cilj raziskave je ugotoviti, kako dobro zmorejo učenci tovrstno znanje, ki so si ga pridobili skozi najrazličnejše načine, uporabiti v različnih, življenjskih, problemsko zasnovanih situacijah, torej tudi v situacijah, s katerimi se bodo dejansko srečevali v poznejšem, vsakdanjem življenju.

\section{Definicija bralne pismenosti}

Definicija bralne pismenosti v raziskavi PISA vključuje različne kognitivne kompetence, od osnovnega prepoznavanja in priklica besedišča, poznavanja slovničnih, jezikovnih ter strukturnih lastnosti določenega besedila, pa vse do splošnega znanja o svetu. Vključuje tudi metakognitivne kompetence: zavedanje in sposobnost uporabe različnih strategij pri usvajanju določenega besedila in reševanju vprašanj, povezanih z njim (OECD, 20ı oa).

Definicija bralne pismenosti v raziskavi PISA 2009 je naslednja:

>Bralna pismenost zajema razumevanje, uporabo, reflektiranje ter osebni interes za pisano besedilo, z namenom razviti lasten potencial in znanje ter aktivno sodelovati v družbi.«(ibid.). 
Razumevanje $\mathrm{v}$ definiciji predstavlja bralčevo sposobnost oblikovanja pomena določenega besedila, uporaba se nanaša na način branja, pri katerem gre za uporabo pridobljenih informacij iz besedila pri razreševanju problemov, ki se navezujejo bodisi na besedilo ali situacije izven besedila, reflektiranje pa pomeni povezovanje prebranega z lastnimi mislimi, predznanjem in izkušnjami. Osebni interes v definiciji predstavlja motivacijo za branje v smislu osebnega interesa za branje (ibid.).

\section{Lestvica bralne pismenosti}

Dosežki učencev na testu bralne pismenosti so v raziskavi PISA opredeljeni s pomočjo lestvice bralne pismenosti. Lestvica dosežkov bralne pismenosti je sestavljena s pomočjo matematičnega modela teorije pojasnjevanja odgovorov (IRT), v katerem se upošteva težavnost nalog ( $\mathrm{tj}$. odstotek učencev, ki so nalogo pravilno rešili) ter uspešnost učencev pri reševanju teh nalog (tj. odstotek pravilnih odgovorov učenca). Na lestvici dosežkov bralne pismenosti, ki jo dobimo iz modela, mesto vsakega učenca kaže na izraženost njegove bralne pismenosti, mesto vsake naloge pa kaže na obseg bralne pismenosti v tej nalogi. Dosežek učenca na lestvici ponazarja stopnjo verjetnosti, da bo učenec z določenih mestom (dosežkom) na lestvici pravilno odgovoril na vprašanje, ki je na istem mestu na lestvici (zaradi svoje težavnosti).

\section{Ciljna populacija v raziskavi PISA 2009}

$\mathrm{V}$ raziskavi PISA je ključni kriterij ciljne populacije starost, ki je natančno opredeljena. $V$ času izvedbe raziskave naj bi dijaki oz. učenci dopolnili starost 15 let in 3 mesece do vključno 16 let in 2 mesecev. Učenci, ki so ustrezali osnovnemu kriteriju raziskave za t. i. »PISA populacijo 2009《, so bili rojeni v koledarskem letu 1993 (od I. januarja 1993 do 3 I. decembra 1993) in so obiskovali najmanj 7. razred osnovne šole. Glavnina is-letnikov v Sloveniji obiskuje r. letnik srednje šole, nekaj jih je še v osnovni šoli, nekaj pa v 2. letniku srednje šole.

Glede na razpoložljivo število is-letnikov v celotni populaciji in skupno število srednjih šol v Sloveniji so v vzorec šol za glavni zajem podatkov vključene vse srednje šole z vsemi izobraževalnimi programi, ki vpisujejo is-letnike. V raziskavo PISA je potrebno vključiti vse institucije, ki vpisujejo I 5 -letnike, zato so v vzorec poleg srednjih šol vključene tudi nekatere osnovne šole in institucije za izobraževanje otrok s posebnimi potrebami ter institucije za izobraževanje odraslih, ki vpisujejo v osnovnošolske ter srednješolske programe. 
Izmed srednješolskih programov je bilo največ programov srednjega tehniškega in strokovnega izobraževanja (Io9), nato srednjega poklicnega izobraževanja (89), klasične in splošne gimnazije (56), nižjega poklicnega izobraževanja (34) ter strokovne gimnazije (33). Poleg srednješolskih programov je sodelovalo še 24 osnovnih šol, v programih za izobraževanje odraslih pa ni bilo vključenih dijakov oz. učencev, ki bi ustrezali merilom za izbor v vzorec.

V raziskavi PISA 2009 je sodelovalo približno 470000 učenk in učencev iz 65 držav.

Slovenski vzorec v raziskavi PISA 2009 je skupaj z dodatnimi dijaki iz I. letnikov obsegal 7764 dijakov iz vseh srednjih šol in gimnazij ter 46 učencev iz 24 osnovnih šol.

\section{Vprasalnik v raziskavi PISA 2009}

Za potrebe naših analiz na tem mestu podrobneje opisujemo predvsem Vprašalnik za dijakinje in dijake (VDD), ki ga dijaki izpolnjujejo po reševanju delovnih zvezkov s kognitivnimi nalogami.

$S$ pomočjo vprašalnika v raziskavi PISA ugotavljamo ozadje dosežka učenca (dijaka) na testu znanja. Področja merjenja v omenjenem vprašalniku so bila naslednja: osnovne lastnosti dijaka/učenca, družinsko ozadje, bralne aktivnosti zunaj šole, čas za učenje, šola in učitelji, pouk slovenščine, knjižnice, strategije branja in razumevanja besedil, uporaba IKT v šoli in doma, izobraževanje do sedaj in načrti za v prihodnje.

Teoretični okvir, na katerem temeljijo vprašalniki za dijakinje in dijake, zajema glavne akterje izobraževalnega sistema na nacionalni, šolski ter individualni ravni, določene vidike produktivnosti izobraževalnega sistema, procese poučevanja ter kontekstualne družbene pogoje učenja in učnih dosežkov. Struktura elementov, ki predstavljajo izhodišča merjenja znotraj vprašalnikov, je predstavljena v tabeli, ki sledi.

Konceptualni okvir vprašalnikov tudi posebej opredeljuje pogoje, ki v učni situaciji spodbujajo učenje in ki so zajeti znotraj vprašanj, ki merijo dejavnike kakovostnega učnega procesa:

- zavedanje zahtevnosti učne situacije ter zavedanje potrebe po aktivnem reševanju problema, zaznavanje učnih zahtev kot izziva;

- motiviranost in volja za reševanje zastavljenih nalog;

- povezovanje dane naloge s poprejšnjim znanjem, navadami in razpoložljivimi spretnostmi;

- $\quad$ kognitivne operacije na različnih taksonomskih ravneh (od memoriranja do kompleksnejših miselnih procesov); 
- $\quad$ uporaba metakognitivnih strategij učenja (postavljanje učnih ciljev ter učnega načrta, uporaba strategij problemskega reševanja nalog, samoevalvacija itd.);

- $\quad$ konstruktivna povratna informacija kot pomemben del spodbujanja samoregulacije pri posamezniku.

Tabela i: Izhodišča merjenja znotraj vprašalnikov

\begin{tabular}{|l|l|l|l|l|}
\hline & Dosežki & Izobraževalniproces & Pogoji izobraževanja & $\begin{array}{l}\text { Ekoloskki in kontekstual- } \\
\text { ni pogoji }\end{array}$ \\
\hline Dijakinje in dijaki & Bralni dosežki & $\begin{array}{l}\text { Čas, namenjen branju } \\
\text { in učenju }\end{array}$ & Učne spretnosti & Kulturni kapital doma \\
\hline Poučevanje & $\begin{array}{l}\text { Povprečen bralni do- } \\
\text { sežek glede na razred }\end{array}$ & $\begin{array}{l}\text { Način poučevanjas } \\
\text { strani učitelja }\end{array}$ & $\begin{array}{l}\text { Struktura razreda gle- } \\
\text { de na socionalnoeko- } \\
\text { nomski status učencev }\end{array}$ & $\begin{array}{l}\text { Interakcija med struk- } \\
\text { turo razreda in razre- } \\
\text { dno klimo }\end{array}$ \\
\hline Izobraževalne institucije & $\begin{array}{l}\text { Povprečni dosežki na } \\
\text { ravni šole }\end{array}$ & $\begin{array}{l}\text { Navodila za poučeva- } \\
\text { nje na ravni šole }\end{array}$ & $\begin{array}{l}\text { Struktura šole gle- } \\
\text { de na socionalnoeko- } \\
\text { nomski status učencev }\end{array}$ & $\begin{array}{l}\text { Interakcija med struk- } \\
\text { turo šole in šolsko } \\
\text { klimo }\end{array}$ \\
\hline $\begin{array}{l}\text { Nacionalni izobraževal- } \\
\text { ni sistem }\end{array}$ & $\begin{array}{l}\text { Bralni dosežki na rav- } \\
\text { ni države }\end{array}$ & $\begin{array}{l}\text { Spremljanje dosežkov } \\
\text { na nacionalni ravni }\end{array}$ & $\begin{array}{l}\text { Kulturna homogenost } \\
\text { populacije }\end{array}$ & $\begin{array}{l}\text { Vrednotenje izobraže- } \\
\text { vanja v družbi }\end{array}$ \\
\hline
\end{tabular}

Vprašanja znotraj vprašalnika za dijakinje in dijake oz. učenke in učence lahko tako v grobem razdelimo na io tematskih sklopov oz. področij, s katerimi skušamo natančneje ugotavljati in pojasnjevati ozadje učenčevega dosežka na testu znanja. Ta področja so naslednja:

- osnovne lastnosti dijaka/učenca (starost, spol, program);

- družinsko ozadje (poklic in izobrazba staršev, kraj rojstva, posedovanje določenih predmetov, npr. knjig ali računalnika);

- bralne aktivnosti zunaj šole;

- čas za učenje;

- $\quad$ šola in učitelji;

- pouk slovenščine;

- knjižnice;

- $\quad$ strategije branja in razumevanja besedil;

- $\quad$ uporaba IKT (informacijsko-komunikacijske tehnologije) v šoli in doma;

3 Vprašalnikom za dijake/učence sta bila na koncu dodana še dva mednarodna dodatka:

- vprašalnik o uporabi računalnikov, ki se osredotoča na: i) dostopnost in uporabo informacijske tehnologije (IT), okolje, v katerem učenec največ uporablja IT, in način, na katerega jo uporablja; ii) ućenćeve spretnosti pri uporabi IT ter odnos do računalnikov; in iii) ugotavljanje izvora znanja IT, torej kje se je učenec naućl uporabljati računalnik in medmrežje. 
- $\quad$ izobraževanje do sedaj in načrti za v prihodnje. V okviru analiz te študije so nas zanimala predvsem vprašanja, ki so dijake spraševala o njihovih bralnih aktivnostih, metakognitivnih in učnih strategijah, uporabi IKT v šoli in doma, stališčih do šole in pouku slovenščine. Posamezna vprašanja so podrobneje predstavljena v nadaljevanju, pred samimi podatki, na katere se navezujejo.

\section{Profil slovenskih dijakov na šestih ravneh bralne pismenostiv raziskavi PISA 2009}

$\mathrm{V}$ predhodnih analizah smo ugotavljali pomembne napovednike bralne pismenosti v raziskavi PISA 2009 pri slovenskih mladostnikih, starih is let, in njihov neodvisen prispevek pri pojasnjevanju bralnih dosežkov. Ugotovili smo, da lahko približno $52 \%$ totalne variance dosežkov dijakov pojasnimo z razlikami med izobraževalnimi programi, približno 3 $\% \mathrm{z}$ razlikami med šolami znotraj izobraževalnih programov in približno $8 \% \mathrm{z}$ razlikami med dijaki znotraj šol. Med slednjimi napovedniki so tisti, ki pozitivno napovedujejo bralne dosežke, naslednji: spol (dekleta), višji indeks socialno-ekonomskega statusa dijaka, slovenščina kot pogovorni jezik doma, indeksi zanimanja za branje, metakognitivne strategije pri branju, pogostejša interpretacija literarnih tekstov, zaznana učiteljeva spodbuda pri bralnih aktivnostih ter pogostejše dejavnosti branja na spletu. Ugotovili pa smo tudi pomembne negativne napovednike bralne pismenosti. Z bralno pismenostjo se, presenetljivo, negativno povezujejo pogostost obiskovanja knjižnice ter pogostost uporabe računalnika v šoli in doma za šolsko delo (Puklek Levpušček, Podlesek in Šterman Ivančič, 20I2).

V nadaljevanju nas je zanimalo, ali lahko na šestih ravneh bralne pismenosti, ki jih določa raziskava PISA, govorimo o tipičnih profilih dijakov na področju motivacije, učenja in nekaterih socialnih dejavnikov. Opisani profili bolj in manj uspešnih dijakov nam lahko dajejo jasnejšo sliko o tem, kakšne so tipične značilnosti slovenskih I5-letnikov, ki se s svojim bralnim dosežkom uvrščajo na posamezno raven bralne pismenosti.

S hierarhičnim linearnim modeliranjem ugotovimo neodvisen prispevek posameznih napovednikov k pojasnjevanju dosežka na testu bralne pismenosti. Neka spremenljivka pa lahko z dosežkom na tem testu pomembno korelira, a se v hierarhičnem modeliranju njenega učinka ne opazi, ker lahko korelira z drugimi pomembnimi napovedniki in si tako z njimi deli varianco dosežka, ki jo pojasnjuje. Tako lahko popolno sliko o odnosu med posameznimi napovedniki in dosežkom na testu bralne pismenosti dobimo, če združimo

- vprašalnik o izobraževalni karieri, ki zajema tri področja: dijakovo oz. učenčevo preteklo izobraževanje, sedanje šolanje ter načrte glede nadaljnjega izobraževanja in zaposlitve. 
obe analizi: hierarhično linearno modeliranje in korelacijo ničelnega reda dosežka s spremenljivko (tj. korelacijo med dosežkom in spremenljivko, pri čemer ne nadzorujemo učinkovanja drugih napovednikov). Da bi bila predstavitev odnosov ničelnega reda nazornejša (da bi zajeli tako linearne kot morebitne nelinearne odnose med napovedniki in dosežkom), smo se odločili, da v naslednjem koraku ne uporabimo korelacij med napovedniki in dosežkom, temveč da prikažemo, kakšne so povprečne vrednosti posameznih napovednikov pri dijakih, ki so dosegli določeno raven bralne pismenosti. Rezultate take analize lahko tudi primerjamo z rezultati mednarodnih analiz, predstavljenih v OECD (2०ı০a).

$\mathrm{V}$ mednarodnih analizah so bile na osnovi niza statističnih principov določene mejne vrednosti sedmih ravni bralne pismenosti (sicer ravni I-6, a najnižja raven se deli na dve podravni, ıa in Ib). Generirani so bili opisi posameznih ravni, in sicer na osnovi nalog, ki so značilne za vsako tako raven (težavnost nalog je opredeljena po teoriji odgovora na postavko). (OECD, 2009a)

\section{Opis ravni dosežkov na šestih ravneh bralne pismenosti}

Ib raven (dosežki, višji od 262 točk in enaki ali nižji od 335 točk)

Opis ravni:

Dijak, ki dosega to raven bralne pismenosti, zna poiskati kratko, eksplicitno navedeno informacijo znotraj danega besedila, ob tem pa sta mu poznana tako slog kot kontekst besedila. Oblikovati zna preproste sklepe, kot je prepoznavanje kavzalne povezanosti med dvema deloma besedila, tudi če nista oba navedena. Naloge na tej ravni od dijakov zahtevajo prepoznavanje določenega dela eksplicitno navedene informacije znotraj preprostega besedila. Znotraj tovrstnega besedila so običajno navedeni znani simboli, slike ali ponovljeni deli besedila, ki služijo kot pomoč pri iskanju prave rešitve. $99 \%$ slovenskih i5-letnikov dosega to raven.

Ia raven (dosežki, višji od 335 točk in enaki ali nižji od 407 točk)

Opis ravni:

Dijak, katerega bralni dosežek je na tej ravni, zna $v$ besedilu poiskati vodilno misel oz. informacijo o poznani temi ter prepoznati povezavo med idejami v besedilu in izkušnjami iz vsakdanjega življenja. Tovrstna naloga od dijaka zahteva, da prepozna enega ali več delov eksplicitno navedene informacije, prepozna glavni namen oz. idejo avtorja ali naredi preprosto povezavo med delom besedila in življenjskimi izkušnjami. Zahtevani podatek iz besedila v večini primerov izstopa. $94 \%$ slovenskih 15 -letnikov dosega to raven. 
2 raven (dosežki, višji od 407 točk in enaki ali nižji od 480 točk)

Opis ravni:

Druga raven bralne pismenosti v raziskavi PISA predstavlja mejo med tem, ali ima dijak znanja ter spretnosti, ki mu bodo pomagale pri aktivnem in produktivnem sodelovanju v družbi, ali ne. Dijak z bralnimi spretnostmi in znanjem na tej ravni zna v besedilu poiskati informacijo, ki ustreza več kriterijem, primerja več značilnosti določenega vidika besedila, prepozna bistvo in glavno idejo dela besedila, tudi če le-ta ni cisto jasno navedena, oblikuje enostavnejše sklepe na podlagi besedila ter besedilo poveže z lastnimi izkušnjami. $79 \%$ slovenskih is-letnikov dosega to raven.

3 raven (dosežki, višji od 480 točk in enaki ali nižji od 553 točk)

Opis ravni:

Dijak, ki dosega to raven bralne pismenosti, uspešno rešuje naloge srednje kompleksnosti. Naloge na tej ravni od dijaka zahtevajo prepoznavo ter ugotavljanje povezanosti med več deli besedila ter informacijami, ki ustrezajo več različnim pogojem. Pri besedilih, ki zahtevajo interpretacijo na tej ravni bralni pismenosti, mora dijak med seboj integrirati različne dele besedila, na podlagi tega identificirati poglavitno idejo le-tega ter samostojno konstruirati pomen besede ali fraze. Ob tem mora razlicne informacije med sabo primerjati, postaviti $v$ kontrast ter jih kategorizirati. V večini primerov te informacije niso enoznačno izpostavljene znotraj besedila in obstaja mnogo, tudi zavajajočih, podobnih podatkov. 53 $\%$ slovenskih is-letnikov dosega to raven.

4 raven (dosežki, višji od 553 točk in enaki ali nižji od 626 točk)

Opis ravni:

Dijaki z doseženo četrto stopnjo bralne pismenosti uspešno rešujejo zahtevne bralne naloge, ki zahtevajo prepoznavanje tudi prikritih delov določene informacije, lastno konstruiranje pomena različnih nians istega besedila, oblikovanje lastnih hipotez o besedilu ter kritično ovrednotenje le-tega, ob čemer pa je treba upoštevati besedilo kot celoto. $24 \%$ slovenskih I5-letnikov dosega to raven.

5 raven (rezultati, višji od 626 točk in enaki ali nižji od 698 točk)

Opis ravni:

Ta raven bralne pismenosti zahteva obvladovanje vseh vrst besedil, tudi nepoznanih po obliki ali vsebini. Dijak, ki izkazuje kompetence na tej ravni, zna znotraj vsakršnega besedila poiskati zahtevane informacije, izkazuje podrobno razumevanje le-tega ter izlušči informacije, ki so za tako besedilo bistvene. Tak posameznik zna tudi kritično ovrednoti- 
ti besedilo, zastaviti hipoteze na podlagi besedila ter ga povezati s svojim specificnim predhodnim znanjem. Naloge na tej ravni navadno zahtevajo obdelavo konceptov, ki niso vsakdanji ali pričakovani. 5 \% slovenskih is-letnikov dosega to raven.

6 raven (rezultati, višji od 698 točk)

Opis ravni:

Bralci, ki dosegajo to raven bralne pismenosti, so znotraj raziskave PISA opredeljeni kot izurjeni bralci. Ob branju znajo združiti eksplicitno podane informacije z različnimi implikacijami, besedilo reflektirajo in ovrednotijo na splošnejši ravni ter operirajo z vsemi vrstami besedil. Glede na standarde raziskave PISA je poglavitna prednost teh I 5 -letnikov ta, da znajo preseči lastne poprejšnje konceptualizacije o določeni tematiki in informacijah, tudi če je poglavitna nova informacija abstraktna, nevsakdanja in nepričakovana. Sposobni so vzpostavljanja kritične distance do prebranega in razvijajo razumevanje, ki presega samo besedilo. Izkazujejo sposobnost absorbiranja in evalviranja novosti ter operiranja $\mathrm{z}$ njimi. $\quad 0,3 \%$ slovenskih is-letnikov dosega to raven.

\section{Motivacija za branje v Sloveniji in drugih državah}

\section{Bralni dosežki}

Slovenija

Povprečni dosežek vseh is-letnikov iz držav OECD, ki so sodelovali v raziskavi PISA 2009, je na testu bralne pismenosti enak 494 točk, povprečni dosežek slovenskih učencev pa 483 točk, kar je pod mednarodnim povprečjem. Povprečni rezultat slovenskih dijakov je tudi pod povprečjem držav Evropske unije (489 točk). Najvišji povprečni dosežek so na testu branja dosegli učenci v Šanghaju ( 556 točk), sledijo pa jim Koreja ( 539 točk), Finska ( 536 točk) ter Hong Kong ( 533 točk). Tako tudi v tem ciklu prednjačijo azijske države, edina evropska država, ki jim stoji ob strani, pa je, tako kot tudi v prejšnjih ciklih, Finska.

Pri dosežkih bralne pismenosti je ponovno opaziti tudi razlike po spolu. Na mednarodni ravni je to razlika 39 točk, v ospredju pa so dekleta ( 513 točk proti 474 točk). Rezultati za Slovenijo so podobni, le da je ta razlika še večja, in sicer 55 točk ( 5 I I točk proti 465 točk), kar predstavlja približno polovico posamezne ravni bralne pismenosti.

Finska

Finska se znotraj raziskave PISA v svojih dosežkih že od samega začetka raziskave (leta 2000) uvršča v sam vrh najuspešnejših držav, na vseh področjih (branju, matematiki in na- 
ravoslovju). Tako se tudi v raziskavi PISA 2009 na testu bralne pismenosti s svojim rezultatom ( 536 točk) postavlja ob bok Koreji, Šanghaju in Hong Kongu.

Finska je v svoji zgodovini prešla mnogo sprememb, ki so se odražale tudi na izobraževalnem sistemu oz. formiranju t. i. enovitega sistema, kateremu se pogosto pripisujejo razlogi za omenjene uspehe.

Finska je relativno mlada država, ki si je svojo neodvisnost od Sovjetske zveze izborila šele po drugi svetovni vojni, ko je v prvih povojnih volitvah dobila svoj parlament. Po vojni je bil napredek v industriji velik in temu je sledila tudi širitev urbanih področij. V poznih 60 . letih je Finsko še vedno sestavljalo $60 \%$ ruralnih področij, od takrat do danes pa je država v dveh tretjinah urbana. Torej, okrog leta 1950 je imel dostop do šole in izobraževanja le majhen odstotek posameznikov. Večina mladih Fincev je v tistem času zapustila šolanje po šestih letih osnovnega šolanja. Konstanten gospodarski in politični razvoj pa je prinesel spremembe tudi v šolskem sistemu. Leta 1968 se je prvič oblikovala ideja o enovitem sistemu, ki je v praksi zaživel šele leta 1977. Danes so učenci vključeni v enoten obvezen sistem izobraževanja do i6. oziroma 17 . leta, če se nato vpisujejo naprej v t. i. višjo srednjo šolo, ki posledično traja 3 leta. Isto število let traja tudi t. i. poklicno izobraževanje. To sta edina tipa srednje šole, ki oba omogočata nadaljevanje študija na različnih univerzah. V kolikor se je posameznik izobraževal v poklicni smeri, je znotraj tega zelo pomembna tudi praksa. Torej, učenci, ki so vključeni v raziskavo PISA, še vedno obiskujejo enovit program osnovnega, obveznega izobraževanja (OECD, 2oı od).

Vendar ni le zasnova strukture izobraževalnega sistem tista, ki je ključna za uspehe učencev. Direktor Nokie, ki je bil v času prenove izobraževalnega sistema eden izmed vodilnih posameznikov pri razvoju gospodarstva $v$ tistem času, je za intervju dejal: $\gg V$ kolikor zaposlimo mladega posameznika, ki ima primanjkljaj v znanju na področju matematike in naravoslovja, imam sodelavce, ki ga to lahko naučijo. Če zaposlim nekoga, ki ne zna sodelovati z drugimi, razmišljati samostojno in kreirati samostojne, izvirne ideje, se bojim, da tukaj ne morem ničesar več storiti. Torej, storite, kar morate storiti z izobraževalnim sistemom, vendar ohranite ustvarjalnost in odprtost do znanja, ki jo imamo.« (ibid.)

Od učencev na Finskem se tako pričakuje, da v procesu učenja timsko sodelujejo na različnih projektih, še posebej pa je poudarek na projektih, ki povezujejo znanja z različnih področij. Na prehodu v višje srednješolsko izobraževanje se tako od njih pričakuje, da so sposobni učinkovite samoregulacije učenja.

Temelji, na katerih sloni izobraževalni sistem na Finskem, so predvsem naslednji: 
- vsesplošna kultura, kjer sta predanost izobraževanju in iskanje znanja pomembni vrednoti;

- prepričanje, da učenčevo ozadje (socialno-ekonomsko in versko) ne sme biti ovira pri doseganju visokih učnih uspehov;

- izreden poudarek na izobraževanju učiteljev in ravnateljev (na Finskem je kariera učitelja že dolgo pojmovana kot ena najboljših, česar posledica je bil dvig standardov ob vpisu na univerze za učitelje);

- odgovornost do otrok, ki imajo učne težave (vsi učitelji so dobro izobraženi na področju ravnanja z učnimi primanjkljaji);

- $\quad$ visoke finančne investicije v izobraževalni sistem (Finska je po sredstvih, ki jih porabi na učenca, med državami OECD na prvem mestu);

- tesna povezanost in sočasnost razvoja izobraževalnega sistema z ekonomskim in socialnim sistemom ter potrebami le-tega;

- spodbujanje vrednot in mišljenja, ki je blizu inovativnim posameznikom: ustvarjalnost, prilagodljivost, iniciativnost, sprejemanje tveganja in sposobnost uporabe znanja v različnih, novih situacijah (ibid.).

Norveška

Norveška je na testu bralne pismenosti v raziskavi PISA 2009 dosegla nadpovprečne rezultate ( 503 proti 493 točk). Še posebej nas zanima zato, ker se je dosežek dijakov na testu PISA v primerjavi s ciklom iz leta 2006 izboljšal. V raziskavi PISA 2006 so bili dosežki norveških učencev znotraj vseh domen (branje, matematika in naravoslovje) podpovprečni, kar je v primerjavi s cikli iz leta 2003 in 2000 , ko so bili rezultati podobni kot leta 2006, predstavljalo precejšen padec. Ti rezultati so na Norveškem skladni tudi z rezultati iz raziskave TIMSS, ki kažejo podobne trende (Kjaernsli in Roe, 201 I).

Norveška je v družbi nordijskih držav na drugem mestu v dosežkih na testu PISA 2009, takoj za Finsko. Če potegnemo vzporednico s finskim šolskim sistemom, opazimo, da tudi na Norveškem učenci zapustijo enovito, osnovno izobraževanje šele pri I6-ih letih.

Obvezno osnovnošolsko izobraževanje traja to let in je sestavljeno iz treh triletij: prvo triletje zajema obdobje od I.-4. razreda (starost 6-1o let), drugo triletje predstavlja obdobje 5.-7. razreda (starosti I0-I3 let) ter tretje triletje 8.-IO. razred (starosti I3-I6 let) (Čad, 20I I).

S Finsko pa imata skupno tudi namenjanje posebnega poudarka izobraževanju in usposabljanju učiteljev, katerega kakovost želijo v prihodnosti še izboljšati na naslednji način: 
- $\quad$ študijski programi za bodoče osnovnošolske učitelje se vsebinsko in didaktično prilagodijo glede na starostne skupine učencev;

- Študijski programi za bodoče učitelje mlajših učencev naj bi bili 4-predmetni, od tega norveščina in matematika obvezni, programi za učitelje starejših učencev pa naj bi bili 3-predmetni;

- $\quad$ poveča se delež učne prakse, ki naj se tudi formalno uredi;

- pričakuje se, da bodo imeli učitelji večinoma magistrsko izobrazbo;

- $\quad$ v študij naj bi privabili najboljše kandidate, zato bodo organizirali promocij-

ske kampanje in pripravili različne finančne spodbude;

- mentorstvo učiteljem pripravnikom naj bi se razširilo na vse nove učitelje (Eurydice Slovenija, 2009).

Tako Slovenija kot Finska in Norveška imajo izobraževalni sistem, kjer učenci prvih devet oziroma deset let obiskujejo enoten program obveznega izobraževanja. Temeljne razlike v bralnih dosežkih držav tako morda ležijo kje drugje kot v sami strukturi izobraževalnega sistema. Finska in Norveška se od Slovenije razlikujeta predvsem v naslednjem: znanje, spodbujanje ustvarjalnosti in iniciativnosti so pomembne družbene vrednote in poučevanje otrok je cenjen poklic. Tako sta izobrazba učiteljev ter njihovo usposabljanje nadvse pomembna, izobraževalni sistem pa so se že skozi zgodovino znali učinkovito povezovati stanjem na socialnem in gospodarstvenem področju.

Podrobnejših analiz o razlogih za padec in ponovno izboljšanje bralnih dosežkov na Norveškem v raziskavi PISA 2009 zaenkrat še ni zaslediti na mednarodni ravni. Zaradi omenjenega napredka Norveške in vsakokratne uspešnosti Finske na testu PISA na vseh področjih merjenja nas $\mathrm{v}$ naših analizah zanima primerjava slovenskih rezultatov $\mathrm{z}$ omenjenima državama. Predvsem želimo raziskati razlike med državami z vidika odnosa i 5 -letnikov do branja, njihovih bralnih aktivnostih na spletu, njihovi uporabi ter vrednotenju različnih metakognitivnih in učnih strategij v procesu učenja, učnega okolja (disciplini v razredu, učiteljevi spodbudi pri branju) ter učinkov omenjenih dejavnikov na bralno pismenost znotraj primerjanih držav.

\section{Bralne aktivnosti ter metakognitivne in učne strategije}

$\mathrm{V}$ nadaljevanju predstavljamo rezultate statističnih analiz PISA 2009 na področju bralnih aktivnosti, motivacije za branje in učnih ter metakognitivnih strategij v Sloveniji, na Finskem in Norveškem. Opisovanje in razlaga rezultatov temelji na že opravljenih analizah PISA 2009 (OECD, 2009a-č). 
Osrednji cilj raziskave PISA 2009 je bil ugotavljanje bralne pismenosti. Prav tako pa so $\mathrm{v}$ raziskavi proučevali tudi, kako so z bralno pismenostjo povezani angažiranost pri bralnih dejavnostih ter pristopi k učenju. V raziskavi PISA 2009 so bralne navade ugotavljali na petih področjih:

- branje za zabavo

- uživanje v branju

- različnost bralnega gradiva

- različnost on-line bralnega gradiva

- branje za šolo

Med pristopi k učenju pa so v raziskavi proučevali naslednja področja:

- $\quad$ strategije memoriranja

- razumevanje in zapomnitev

- povzemanje

- strategije elaboracije

- $\quad$ kontrolne strategije

\section{Branje za zabavo}

Količina časa, ki ga mladostnik posveti branju za zabavo, je pokazatelj njegovega zanimanja za branje. Povezuje se $\mathrm{z}$ boljšim razumevanjem prebranega in večjim besednim zakladom bralca (Baker in Wigfield, 1999). Med bralnimi aktivnostmi in dosežki velja krožna zveza: boljši bralci berejo več, ker so bolj motivirani za branje, kar posledično vodi v boljše bralne kompetence (razumevanje prebranega, besedni zaklad).

Tako Finska kot Norveška sta državi, ki sta se na testu bralne pismenosti uvrstili nad povprečje držav OECD oziroma v primeru Finske v sam vrh (536 in 503 točk proti 493 točk). Rezultati v tabeli kažejo, da so dijaki, ki berejo za zabavo (ne glede na čas branja), na testu bralne pismenosti v povprečju dosegali višje rezultate od dijakov, ki ne berejo za zabavo, in sicer so razlike med omenjenimi dijaki znotraj primerjanih držav približno enake ( 66 točk več na Finskem, 65 točk več na Norveškem ter 63 točk več v Sloveniji). Znotraj vseh omenjenih držav pa velja tudi, da so razlike v bralnih dosežkih med dijaki, ki v prostem času na dan berejo približno 30 minut ali eno uro, in tistimi, ki berejo več kot dve uri, dokaj majhne v primerjavi z razlikami med tistimi dijaki, ki ne berejo za zabavo ali v prostem času na dan berejo le 30 minut ali manj. Tako je, denimo, med dijaki v Sloveniji in na Finskem, ki ne berejo za zabavo in njihovimi vrstniki, ki berejo 30 minut ali manj 
na dan, razlika v bralnem dosežku 53 točk, na Norveškem pa 58 točk. Prav tako je znotraj vseh primerjanih držav opaziti, da tako kot na povprečni ravni držav OECD najvišje bralne dosežke v povprečju dosegajo dijaki, ki berejo od I do 2 uri na dan ( 532 točk v povprečju OECD, 572 točk na Finskem, 542 točk na Norveškem ter 520 točk v Sloveniji), in ne tisti, ki v prostem času za zabavo berejo največ, tj. več kot 2 uri dnevno.

Tabela 2: Odstotek odgovorov na vprašanje: Približno koliko časa navadno nameniš branju za zabavo?

\begin{tabular}{|c|c|c|c|c|c|}
\hline & $\begin{array}{l}\text { Ne berem za za- } \\
\text { bavo. }\end{array}$ & $\begin{array}{l}30 \text { minut ali manj } \\
\text { na dan. }\end{array}$ & $\begin{array}{l}\text { Več kot } 30 \text { minut } \\
\text { in manj kot } 60 \text { mi- } \\
\text { nut na dan. }\end{array}$ & $\begin{array}{l}\text { Od I do } 2 \text { uri na } \\
\text { dan. }\end{array}$ & $\begin{array}{l}\text { Več kot } 2 \text { uri na } \\
\text { dan. }\end{array}$ \\
\hline \multicolumn{6}{|l|}{ Finska } \\
\hline$\%$ dijakov* & 33,0 & 32,4 & 18,6 & 12,7 & 3,2 \\
\hline Bralni dosežek & 492 & 545 & 569 & 572 & 568 \\
\hline \multicolumn{6}{|l|}{ Norveška } \\
\hline$\%$ dijakov $^{*}$ & 40,0 & 32,9 & 16,8 & 6,9 & 3,4 \\
\hline Bralni dosežek & 465 & 523 & 540 & 542 & 528 \\
\hline \multicolumn{6}{|c|}{ Povprečje OECD } \\
\hline \% dijakov** & 37,4 & 30,3 & 17,2 & 10,6 & 4,5 \\
\hline Bralni dosežek & 460 & 504 & 527 & 532 & 527 \\
\hline \multicolumn{6}{|l|}{ Slovenija } \\
\hline$\%$ dijakov $^{*}$ & 39,8 & 34,5 & 15,6 & 8,0 & 2,2 \\
\hline Bralni dosežek & 446 & 499 & 526 & 520 & 521 \\
\hline
\end{tabular}

* Odstotek dijakov, ki so določeno postavko označili. Navodilo je zahtevalo, da respondent označi en kvadratek.

V grobem lahko rečemo, da količina časa, ki ga dijaki namenjajo branju v prostem času, pozitivno učinkuje na dosežke na testu bralne pismenosti tudi na Finskem in Norveškem. Tukaj dijaki, ki berejo v prostem času, v povprečju dosegajo še višje dosežke na testu bralne pismenosti od svojih vrstnikov v Sloveniji. Primerjava ponovno kaže tudi, da bralni dosežki v nobeni izmed držav ne naraščajo premosorazmerno s količino časa, ki ga dijaki namenijo branju. Bolj kot to, koliko dijaki v prostem času berejo, je pomembno to, da dijaki branje sprejmejo kot dejavnost, ki jo radi počnejo v prostem času in ji vsakodnevno posvetijo vsaj nekaj minut. 
Indeks uživanja $v$ branju

Notranja motiviranost ter uživanje ob učenju določenega predmeta ali snovi vpliva na stopnjo in kontinuiranost učenja pri tem predmetu in doseženo globino razumevanja. Učenci, ki uživajo pri branju, imajo večjo bralno kompetentnost ter kažejo bolj poglobljeno razumevanje prebranega (Schiefele, 2009). Ta učinek je lahko povsem neodvisen od učenčeve splošne motiviranosti za učenje. Zato so v raziskavi PISA 2009 raje kot splošno motiviranost za učenje proučili zanimanje in uživanje I5-letnikov v branju oz. ugotavljali, $\mathrm{v}$ katerih kontekstih mladostniki uživajo $\mathrm{v}$ branju in $\mathrm{v}$ katerih kontekstih jim branje predstavlja le dolžnost ali jim je celo odveč. Takšne specifične informacije so lahko v pomoč izobraževalnim sistemom pri razmisleku, kako dvigniti bralno kulturo med različnimi skupinami mladostnikov.

Uživanje v branju je v raziskavi PISA 2009 opredeljeno z naslednji trditvami:

I Branjeje eden izmed mojih najljubsib konjickov.

2 O knjigah se rad/-a pogovarjam $z$ drugimi.

3 Vesel/-a sem, če za darilo dobim knjigo.

4 Uživam, kadar grem v knjigarno ali knjižnico.

5 Rad/-a izrazim mnenje o knjigah, ki sem jih prebral/-a.

6 Rad/-a si izmenjujem knjige s prijatelji.

V indeks uživanja v branju so vključene tudi naslednje trditve, ki jih vrednotimo obrnjeno:

7 Berem le, če moram.

8 Knjiges težavo preberem do konca.

9 Branje se mi zdi izguba časa.

Io Berem le zato, da dobim informacije, ki jih potrebujem.

II Ne morem sedeti pri miru in brati več kot nekaj minut.

Dijaki so na omenjene postavke odgovarjali na 4-stopenjski lestvici: $\mathrm{I}=$ Sploh se ne strinjam, $2=$ Ne strinjam se, $3=$ Strinjam se, $4=$ Popolnoma se strinjam.

$\mathrm{Na}$ ravni povprečja držav OECD lahko opazimo relativno visok delež is-letnikov, ki poročajo, da berejo le, ko je to potrebno (41,2 \%) in le zato, da dobijo informacije, ki jih potrebujejo (45,7 \%). Podoben in celo slabši odnos do branja je zaznati na Norveškem $(44,4 \%$ in $50,3 \%$ ), predvsem pa v Sloveniji, kjer več kot polovica I5-letnikov poroča o tem, da berejo le zato, da dobijo informacije, ki jih potrebujejo. Podoben odstotek slovenskih dijakov $(52,8 \%)$ se strinja tudi s trditvijo »Berem le, če moram « (7). Na Finskem je poleg Japon- 
ske in Koreje pri teh postavkah zaslediti najnižje odstotke strinjanja I 5 -letnikov z že omenjenimi trditvami $(36,3 \%$ in $34,7 \%)$.

Tabela 3: Odstotek dijakov, ki so na posamezne trditve odgovarjali s »Strinjam se« in »Popolnoma se strinjam $\ll$

\begin{tabular}{|c|c|c|c|c|c|c|c|c|c|c|c|}
\hline & I & 2 & 3 & 4 & 5 & 6 & 7 & 8 & 9 & 10 & II \\
\hline \multicolumn{12}{|l|}{ Finska } \\
\hline$\%$ dijakov & 34,0 & 34,1 & 52,1 & 47,6 & 58,3 & 26,4 & 34,7 & 27,2 & 27,3 & 36,3 & 14,5 \\
\hline \multicolumn{12}{|l|}{ Norveška } \\
\hline \% dijakov & 22,0 & $28, I$ & 40,4 & 31,2 & 62,0 & 24,0 & 44,4 & 28,8 & 29,9 & 50,3 & 24,9 \\
\hline \multicolumn{12}{|c|}{ Povprečje OECD } \\
\hline \% dijakov & 32,9 & 37,6 & 46,4 & 42,0 & 56,7 & 36,2 & 41,2 & 32,5 & 24,2 & 45,7 & 25,0 \\
\hline \multicolumn{12}{|l|}{ Slovenija } \\
\hline$\%$ dijakov & 23,2 & 34,5 & 37,5 & 35,0 & 54,9 & 33,0 & 52,8 & $34, \mathrm{I}$ & 33,4 & 53,1 & 27,9 \\
\hline
\end{tabular}

Številke 1-11 označujejo zaporedne številke trditev, ki so prikazane v besedilu pred tabelo.

Kot že rečeno, je delež I 5 -letnikov, ki izražajo dokaj negativen odnos do branja, na ravni povprečja držav OECD dokaj visok. Is-letniki na Finskem, ki se po dosežku na testu bralne pismenosti uvršča v sam vrh, so v povprečju tudi bolj naklonjeni branju. Tudi na Norveškem, kjer se v raziskavi PISA 2009 z rezultatom uvrščajo nad povprečje OECD in so v primerjavi z letom 2006 napredovali po lestvici bralne pismenosti, je v primerjavi s I5-letniki v Sloveniji zaslediti malce večjo naklonjenost branju, vendar je delež dijakov, ki berejo predvsem, da dobijo informacije, ki jih potrebujejo, še vedno relativno visok.

V kolikor pogledamo deleže variabilnosti v bralnih dosežkih, ki jih lahko pojasnimo z omenjenim indeksom, opazimo, da je le-ta na Finskem in Norveškem v primerjavi s povprečjem držav OECD in tudi Slovenijo višji. Največji delež variance v bralnih dosežkih lahko z omenjenim indeksom pojasnimo na Finskem (27 \%), temu sledi Norveška z 22,2 \%, v Sloveniji pa lahko z omenjenim indeksom pojasnimo $17,4 \%$ variance v bralnih dosežkih. $\mathrm{V}$ državah OECD omenjeni indeks v povprečju pojasni I 8, I \% variance v bralnih dosežkih.

$\mathrm{V}$ povprečju so v državah OECD eno enoto višje vrednosti indeksa uživanja v branju povezane z 39,5 točk višjimi dosežki na lestvici bralnih dosežkov. V Sloveniji ta povezava pomeni 39 točk, ${ }^{4}$ na Finskem in Norveškem pa še več, in sicer kar 43,3 in 42, I točk. Po-

4 26,6 točk po nadzoru spremenljivk, kot so spol, indeks ekonomskega, socialnega in kulturnega statusa, imigrantski status in jezik, ki ga udeleženci govorijo doma. 
membno je omeniti, da prirast 39 točk na ravni držav OECD pomeni povprečen napredek I5-letnika v branju v enem šolskem letu. Med slovenskimi dijaki, ki se z rezultatom v indeksu uživanja v branju uvrščajo v najnižjo četrtino rezultatov, je bralni dosežek za 98 točk nižji kot med dijaki, ki se na omenjenem indeksu uvrščajo v najvišjo četrtino rezultatov (445 proti 543 točk), na Finskem I2 I točk (475 proti 596) in na Norveškem I I 4 točk (450 proti 564 točk).

Uživanje v branju se je pokazalo kot pomemben dejavnik pripojasnjevanju bralnepismenosti $v$ vseh treh primerjanih državah, saj dijaki, ki poročajo o večji naklonjenosti branju, $v$ vseh treh državah v povprečju dosegajo tudi višje rezultate na testu branja. Dijaki, ki poročajo o večji naklonjenosti branju na Finskem in Norveškem, pa v povprečju dosegajo precej višje dosežke na testu branja od svojih vrstnikov v Sloveniji.

\section{Indeks različnosti bralnega gradiva}

Pomembno je vprašanje, katere vrste bralnega gradiva so pri dijakih najbolj učinkovite za spodbujanje bralnih spretnosti in izboljševanje bralnih dosežkov. Čeprav za dijake, ki berejo leposlovje, velja, da imajo boljše bralne dosežke, pa rezultati PISA 2009 kažejo tudi na to, da so najbolj uspešni tisti is-letniki, ki berejo različne vrste bralnega gradiva.

Vprašanje o različnosti bralnega gradiva se je v raziskavi PISA 2009 glasilo:

Kako pogosto bereš naslednje gradivo zato, ker to želiš?
a) Revije
b) Stripe
c) Leposlovje (romane, pripovedi, zgodbe)
d) Knjige, ki niso leposlovje
e) Časopise

Udeleženci so pri posamezni vrsti bralnega gradiva označili enega od možnih odgovorov: $\mathrm{I}=$ Nikoli ali skoraj nikoli, $2=$ Nekajkrat na leto, $3=$ Približno enkrat na mesec, $4=$ Večkrat na mesec, $5=$ Večkrat na teden.

Indeks različnosti bralnega gradiva tako pomeni pogostnost branja posameznih vrst bralnega gradiva. Višji indeks pomeni večjo različnost pri branju. 
Tabela 4: Odstotek dijakov, ki berejo bralno gradivo »večkrat na mesec« ali »večkrat na teden $\ll$

\begin{tabular}{|c|c|c|c|c|c|}
\hline & Revije & Stripi & Leposlovje & $\begin{array}{l}\text { Knjige, ki niso le- } \\
\text { poslovje }\end{array}$ & Časopisi \\
\hline \multicolumn{6}{|l|}{ Finska } \\
\hline \% dijakov & 64,9 & 60,1 & 26,1 & 15,5 & 75,4 \\
\hline Bralni dosežek & 551 & 540 & 590 & 558 & 540 \\
\hline \multicolumn{6}{|l|}{ Norveška } \\
\hline$\%$ dijakov & 60,6 & 42,2 & 26,3 & 27,2 & 73,4 \\
\hline Bralni dosežek & 511 & 517 & 551 & 507 & 510 \\
\hline \multicolumn{6}{|c|}{ Povprečje OECD } \\
\hline$\%$ dijakov & 58,2 & 22,4 & 30,6 & 18,7 & 62,3 \\
\hline Bralni dosežek & 501 & 492 & 533 & 513 & 501 \\
\hline \multicolumn{6}{|l|}{ Slovenija } \\
\hline$\%$ dijakov & 72,6 & 14,8 & 15,4 & 16,3 & 71,7 \\
\hline Bralni dosežek & $49 \mathrm{I}$ & 474 & 538 & 527 & 488 \\
\hline
\end{tabular}

Tabela s: Odstotek dijakov, ki berejo različne kombinacije bralnih gradiv »večkrat na mesec« ali »večkrat na teden«, ter njihovi povprečni bralni dosežki

\begin{tabular}{|c|c|c|c|c|c|}
\hline & $\begin{array}{l}\text { Leposlovje in dru- } \\
\text { go razen stripov }\end{array}$ & $\begin{array}{l}\text { Leposlovje, drugo } \\
\text { in stripe }\end{array}$ & $\begin{array}{l}\text { Stripe in drugo ra- } \\
\text { zen leposlovja }\end{array}$ & $\begin{array}{l}\text { Drugo razen le- } \\
\text { poslovja in stripov }\end{array}$ & $\begin{array}{l}\text { Nič od omenje- } \\
\text { nega }\end{array}$ \\
\hline \multicolumn{6}{|l|}{ Finska } \\
\hline \% dijakov & 9,9 & 16,2 & 43,9 & $24, \mathrm{I}$ & 5,8 \\
\hline Bralni dosežek & 588 & 593 & 522 & 521 & 475 \\
\hline \multicolumn{6}{|l|}{ Norveška } \\
\hline$\%$ dijakov & 13,5 & 12,9 & 29,3 & 36,0 & 8,3 \\
\hline Bralni dosežek & 546 & 556 & 501 & 486 & 450 \\
\hline \multicolumn{6}{|c|}{ Povprečje OECD } \\
\hline$\%$ dijakov & 21,7 & 8,9 & 13,4 & 42,4 & 13,6 \\
\hline Bralni dosežek & 538 & 518 & 478 & 487 & 457 \\
\hline
\end{tabular}




\begin{tabular}{|c|c|c|c|c|c|}
\hline & $\begin{array}{l}\text { Leposlovje in dru- } \\
\text { go razen stripov }\end{array}$ & $\begin{array}{l}\text { Leposlovje, drugo } \\
\text { in stripe }\end{array}$ & $\begin{array}{l}\text { Stripe in drugo ra- } \\
\text { zen leposlovja }\end{array}$ & $\begin{array}{l}\text { Drugo razen le- } \\
\text { poslovja in stripov }\end{array}$ & $\begin{array}{l}\text { Nič od omenje- } \\
\text { nega }\end{array}$ \\
\hline \multicolumn{6}{|l|}{ Slovenija } \\
\hline$\%$ dijakov & 12,5 & 2,9 & 11,8 & 62,4 & 10,3 \\
\hline Bralni dosežek & 546 & 510 & 465 & 483 & 450 \\
\hline
\end{tabular}

Iz rezultatov je razvidno, da najvišje dosežke na testu bralne pismenosti dosegajo dijaki, ki večkrat na mesec ali teden berejo leposlovje. Ta rezultat je opaziti v vseh primerjanih državah, je pa odstotek omenjenih dijakov nižji od povprečja $\operatorname{OECD~}(30,6 \%)$ tako v Sloveniji (15,4 \%) kot tudi na Norveškem (26,3 \%) in Finskem (26,1 \%). Norveška in Finska sta glede na omenjeni rezultat bližje povprečju OECD, odstotek omenjenih dijakov pa je v primerjavi s Slovenijo višji kar za i I \%. Rezultati kažejo tudi, da je v omenjenih državah največ takih I5-letnikov, ki večkrat na mesec ali večkrat na teden berejo revije in časopise. Odstotki omenjenih dijakov se tako v Sloveniji kot na Norveškem in Finskem gibljejo nad povprečjem držav OECD, je pa odstotek dijakov, ki večkrat na teden ali mesec berejo revije, najvišji v Sloveniji (72,6 \% v Sloveniji, 64,9 \% na Finskem in 60,6 \% na Norveškem), glede na pogostost branja časopisov pa ne odstopamo bistveno od severnih držav. Na Finskem in Norveškem je v primerjavi s Slovenijo opaziti tudi večje poseganje I5-letnikov po stripih, saj sta tako na Norveškem kot na Finskem odstotka I5-letnikov, ki poročajo o pogostem branju stripov, visoko nad povprečjem (22,4 \% proti $42,2 \%$ in 60,1 \%). Slovenski dijaki v primerjavi z vrstniki na Finskem, Norveškem kot tudi na ravni držav OECD tako manj berejo leposlovje, $v$ vseh treh primerjanih državah pa dijaki izstopajo po pogostosti branja revij in ćasopisov.

Če pogledamo še podatke o raznovrstnosti bralnega gradiva, tudi tukaj opazimo, da najvišje dosežke na testu bralne pismenosti v vseh treh primerjanih državah dosegajo dijaki, ki berejo raznovrstno gradivo, vključujoč leposlovje, na Norveškem in Finskem, kjer so dosežki visoko nad povprečjem ( 556 in 593 točk proti 518), pa tudi stripe. Dijakov, ki bi brali raznovrstno bralno gradivo (poleg že omenjenega tudi leposlovje in stripe), je na ravni povprečja OECD manj kot Io \%, v Sloveniji pa približno 3 \%. Na Finskem in Norveškem je na tem področju drugače, saj približno I6 \% dijakov na Finskem in $13 \%$ dijakov na Norveškem bere raznovrstnejše gradivo, vključujoč leposlovje in stripe, kar je za kar ıo $\%$ več kot v Sloveniji.

V Sloveniji je v primerjavi s povprečjem držav OECD manj prisotno branje leposlovja in drugega bralnega gradiva razen stripov, čeprav se prav v tej skupini nahajajo dijaki, ki imajo najvišje ravni bralnih dosežkov. Ti se, denimo, v Sloveniji razlikujejo od bralnih do- 
sežkov dijakov, ki berejo v manjši meri ali sploh ne berejo različnega bralnega gradiva, za 94 točk ( 546 proti 450 točk), kar prve uvršča za več kot eno raven višje na lestvici bralne pismenosti. Med bralnimi gradivi so največje razlike med dijaki, ki pogosto segajo po leposlovju, in vrstniki, ki to počnejo občasno ali nikoli ( 538 proti 476 točk). Na Finskem in Norveškem je slika podobna, le da so tam razlike še večje, in sicer so največje razlike med dijaki, ki berejo različno bralno gradivo z leposlovjem in tudi stripi ter tistimi, ki to počnejo redko ali nikoli ( 593 proti 475 na Finskem in 556 proti 450 na Norveškem).

Dijaki, ki so bralci raznovrstnega bralnega gradiva, tako dosegajo boljše rezultate na testu bralne pismenosti v vseh treh primerjanih državah. Najvišje bralne dosežke v Sloveniji tako dosegajo dijaki, ki berejo leposlovje in knjige, ki niso leposlovje, na Finskem in Norveskem pa se je, zanimivo, $v$ kombinaciji z leposlovjem kot pozitivno pokazalo tudi branje stripov.

V povprečju držav OECD in v Sloveniji lahko 6 \% variabilnosti v bralnih dosežkih na testu raziskave PISA pojasnimo $\mathrm{z}$ indeksom različnosti bralnega gradiva, kar je manj kot na Finskem in Norveškem ( $13,7 \%$ in $8,5 \%)$. V povprečju so v državah OECD eno enoto višje vrednosti indeksa uživanja v branju povezane z 21,9 točk višjimi dosežki na lestvici bralnih dosežkov. V Sloveniji ta povezava pomeni 26,3 točke, ${ }^{5}$ podobno na Norveškem, 25,9 točk, in na Finskem, kar 37,9 točk.

Različnost bralnega gradiva se kaže kot pomemben dejavnik pri pojasnjevanju dosežkov na testu bralne pismenosti v vseh primerjanih državah. Dijaki na Finskem in Norveškem v povprečju berejo već leposlovja in tudi bolj raznovrstno gradivo kot njihovi vrstniki v Sloveniji. Ti dijaki pa v povprečju dosegajo tudi višje rezultate na testu bralne pismenosti od slovenskih dijakov.

\section{Indeks dejavnosti branja na spletu}

Angažiranost pri branju se v sodobnem svetu kaže tudi v različnosti gradiva, ki ga mladostniki berejo na spletu, in v časa, ki ga porabijo za te dejavnosti. V povprečju so dijaki, ki so v večji meri udeleženi pri dejavnostih, kot so branje elektronske pošte, udeležba v spletnih klepetalnicah, branje novic po spletu, uporaba slovarjev in enciklopedij na spletu, udeležba v skupinskih diskusijah na spletu in iskanje informacij po spletu, kompetentnejši bralci kot vrstniki, ki se v tovrstnih aktivnostih le malo ali sploh ne angažirajo.

V raziskavi PISA 2009 so dejavnosti branja na spletu ugotavljali z naslednjim vprašanjem:

517 točk po nadzoru spremenljivk, kot so spol, indeks ekonomskega, socialnega in kulturnega statusa, imigrantski status in jezik, ki ga udeleženci govorijo doma. 
Kako pogosto se ukvarjašz naslednjimi bralnimi aktivnostmi?

a) Branje elektronske pošte

b) Spletne klepetalnice

c) Branje spletnih novic

d) Uporaba spletnega slovarja ali enciklopedije

e) Iskanje spletnih informacij o določenih vsebinah

f) Sodelovanje v skupinskih razpravah ali forumih na spletu

g) Iskanje uporabnih informacij na spletu

Udeleženci so pri posamezni dejavnosti branja po spletu označili enega od možnih odgovorov: $\mathrm{I}=\mathrm{Ne}$ vem, kaj je to, $2=$ Nikoli ali skoraj nikoli, $3=$ Večkrat na mesec, $4=$ Večkrat na teden, $5=$ Večkrat na dan.

Višji indeks dejavnosti branja na spletu pomeni pogostejše ukvarjanje z različnimi dejavnostmi spletnega branja.

Tabela 6: Odstotek dijakov, ki se ukvarjajo z različnimi bralnimi aktivnostmi na spletu »več-

krat na teden« ali »večkrat na dan

\begin{tabular}{|c|c|c|c|c|c|c|c|}
\hline & $\mathrm{a}$ & b & c & d & e & $\mathrm{f}$ & $\mathrm{g}$ \\
\hline \multicolumn{8}{|l|}{ Finska } \\
\hline$\%$ dijakov & 64,0 & 80,8 & 35,0 & 39,4 & 30,0 & 26,1 & 28,4 \\
\hline \multicolumn{8}{|l|}{ Norveška } \\
\hline \% dijakov & 65,8 & 86,4 & 45,0 & 53,8 & 53,4 & $22, \mathrm{I}$ & $34, \mathrm{I}$ \\
\hline \multicolumn{8}{|c|}{ Povprečje OECD } \\
\hline$\%$ dijakov & 63,7 & 73,3 & 45,7 & 39 & 51,3 & 19,6 & 35,5 \\
\hline \multicolumn{8}{|l|}{ Slovenija } \\
\hline \% dijakov & 70,4 & 83,2 & 58,8 & 34,7 & 49,2 & 29,3 & 37,3 \\
\hline
\end{tabular}

Dejavnosti branja na spletu so označene s črkami od a do g, kot so bile označene tudi v vprašanju.

Če primerjamo ukvarjanje slovenskih, norveških in finskih is-letnikov z različnimi bralnimi aktivnostmi na spletu, opazimo, da so odstotki dijakov, ki so na različne načine aktivni na spletu (torej znotraj vseh postavk), med tremi primerjanimi državami v povprečju najnižji na Finskem, na prvem mestu pa je Norveška. V vseh treh državah se is-letniki v največji meri poslužujejo uporabe spletnih klepetalnic (8o,8 \% na Finskem, 86,4 \% na 
Norveškem in 83,2 \% v Sloveniji), najmanj pa se udeležujejo skupinskih razprav na forumih (v največji meri o tem poročajo dijaki v Sloveniji, in sicer v 29,3\%). Znotraj vseh treh primerjanih držav z večjo pogostostjo ukvarjanja z različnimi bralnimi dejavnostmi na spletu narašča tudi bralni dosežek. Vendar dijaki, ki se glede na aktivnosti na spletu uvrščajo v najvišjo četrtino indeksa, ne dosegajo tudi najvišjih dosežkov na lestvici bralne pismenosti, ampak podobnega kot dijaki, ki se nahajajo v tretji četrtini indeksa dejavnosti branja na spletu. V povprečju je razlika na testu bralne pismenosti pri dijakih, ki poročajo o nizki udeležbi v bralnih aktivnostih na spletu, in tistimi, ki so v omenjenih dejavnostih precej aktivni, na ravni držav OECD 37 točk (468 proti 505 točk), v Sloveniji 32 točk (46I proti 493 točk), na Finskem 27 točk ( 517 proti 544 točk) ter na Norveškem I 8 točk (488 proti 508 točk).

V povprečju držav OECD lahko 3 \% variabilnosti v bralnih dosežkih na testu bralne pismenosti pojasnimo z indeksom dejavnosti branja na spletu. V Sloveniji je odstotek pojasnjene variance še nižji, tj. 2 \%, na Finskem I,8 \%, na Norveškem pa le 0,5 \%.

Rezultati kažejo, da se v povprečju v največji meri z bralnimi aktivnostmi na spletu ukvarjajo Is-letniki na Norveškem, najmanj pa na Finskem, ki je v povprečju na testu bralne pismenosti med primerjanimi državami dosegla najvišji rezultat. Torej, dijaki, ki se ukvarjajo z bralnimi aktivnostmi na spletu, v povprečju znotraj vseh treh držav dosegajo tudi višje dosežke na testu bralne pismenosti, vendar ne, če se s temi ukvarjajo v zelo veliki meri (to potrjuje podatek o dosežkih dijakov, ki se uvrščajo v najvišjo četrtino indeksa). Na Finskem se eno enoto višje vrednosti indeksa povezujejo s I 4,5 točkami več na testu bralne pismenosti, v Sloveniji z i I,9 točkami ter na ravni držav OECD z I 4,9 točkami. Najnižji prirast točk (7,5 točk) je zaznati na Norveškem, kar je skladno s podatkom, da prekomerno ukvarjanje z bralnimi aktivnostmi na spletu ne vodi nujno tudi do višjih dosežkov na testu bralne pismenosti.

\section{Metakognitive in ućne strategije}

Učenci v procesu sprejemanja in procesiranja informacij niso pasivni. Kot aktivni udeleženci v učnem procesu konstruirajo pomen s pomočjo preteklega znanja in izkušenj ter značilnosti besedila (Goldman in Rakestraw, 2000). Učenci, ki znajo uravnavati svoje učenje, izbirajo učinkovite učne cilje, uporabljajo svoje znanje in spretnosti, da lažje usmerjajo učenje, in izbirajo učne strategije glede na vrsto in zahtevnost naloge (Zimmerman in Cleary, 2009). Omenjene metakognitivne spretnosti nimajo samo pozitivnega učinka na učno uspešnost, ampak so tudi potrebne za vseživljenjsko učenje (Boekaerts, 2009). Učinkovito procesiranje informacij pri učenju zahteva zmožnost povezovati novo učno snov s pre- 
teklim znanjem ter zavedanje, kako bi pridobljeno znanje učenec lahko uporabil v resničnem svetu. Pomembno je, da ima učenec nabor različnih učnih strategij in da je pri njihovi uporabi fleksibilen glede na vrsto in zahtevnost naloge, glede na svoje predznanje in zmožnosti ter glede na zahteve okolja, v katerem mora izkazati svoje znanje.

\section{Metakognitivne strategije: indeks strategij za razumevanje in pomnjenje besedila}

V raziskavi PISA 2009 so metakognitivne strategije 15 -letnikov ugotavljali z njihovim zavedanjem uporabnosti bralnih strategij pri različnih bralnih nalogah. Dve vprašanji sta vsebovali različni bralni nalogi, sledil pa je seznam pristopov oz. »strategij«. Dijak mora razmisliti o uporabnosti vsake izmed strategij v povezavi s predstavljeno bralno nalogo.

Uporabnost strategij za razumevanje in pomnjenje besedila so $\mathrm{v}$ raziskavi preverjali z vprašanjem, kjer je bila na začetku opisana bralna naloga:

Informacijo $v$ besedilu moraš razumeti in si jo zapomniti.

Sledilo je vprašanje:

Kako ocenjuješ uporabnost naslednjih strategij za razumevanje in pomnjenje besedila?

Možne strategije, ki so jih ocenjevali dijaki, so bile naslednje:

a) Osredotočim se na dele besedila, ki jih z labkoto razumem.

b) Dvakrat hitro preberem besedilo.

c) Po tem ko preberem besedilo, se o njegovi vsebini pogovarjam z drugimi.

d) Podcrtam pomembne dele besedila.

e) S svojimi besedami povzamem besedilo.

f) Besedilo na glas preberem nekomu drugemu.

Udeleženci so na trditve odgovarjali s 6-stopenjsko lestvico, pri čemer I pomeni $\gg$ Sploh ni uporabna $\ll$ in 6 »Zelo je uporabna «.

Strategije c, d in e so v raziskavi PISA 2009 označene kot učinkovitejše strategije za razumevanje in pomnjenje besedila, medtem ko so strategije $a, b$ in foznačene kot manj učinkovite. Indeks strategij za razumevanje in pomnjenje besedila je standardizirana vrednost $s$ povprečjem o in standardnim odklonom $\mathrm{I}$. Višje vrednosti indeksa pomenijo, da dijaki ocenjujejo večjo pomembnost (sploh učinkovitih) strategij za učenje. Vrednosti indeksa so v vseh primerjanih državah dokaj nizke. Najvišjo vrednost indeksa strategij za razumevanje in pomnjenje besedila je zabeležila Finska, in sicer 0,03, kar je malo nad povprečjem držav OECD (০,০o). Pri slovenskih dijakih vrednost indeksa znaša -0,07 in je nekoliko pod povprečjem, na Norveškem pa so vrednosti omenjenega indeksa še bolj pod- 
povprečne, -0,30. V povprečju držav OECD lahko I5,2 \% variabilnosti v bralnih dosežkih na testu PISA 2009 pojasnimo z indeksom strategij za razumevanje in pomnjenje besedila. V Sloveniji je odstotek pojasnjene variance nekoliko višji, tj. I6,9 \%, na Finskem i 7,6 $\%$, na Norveškem pa se omenjena vrednost ponovno giblje pod povprečjem držav OECD, I4,I \%. V povprečju so v državah OECD eno enoto višje vrednosti omenjenega indeksa povezane z za 35, 4 točk (v Sloveniji pa z za 36 točk) višjimi dosežki na lestvici bralnih dosežkov. Podobno je tudi na Finskem ( 35,4 točk) in Norveškem (33, I točk). Če primerjamo bralne dosežke dijakov glede na četrtino indeksa, v katero se uvrščajo, ugotovimo, da se v najvišjo četrtino indeksa v vseh treh državah uvrščajo dijaki z najvišjimi dosežki na testu bralne pismenosti. Razlike v dosežkih med dijaki, ki se nahajajo v prvi in zadnji četrtini indeksa, so v Sloveniji 92 točk (44I proti 533 točk), na Finskem 91 točk (490 proti 58I) in na Norveškem 89 točk ( 460 proti 549 točk). Dijaki na Finskem, ki se z omenjenim indeksom uvrščajo v najnižjo četrtino vrednosti indeksa, so tako v povprečju dosegli višji dosežek na testu bralne pismenosti, od povprečnega skupnega dosežka v Sloveniji (490 proti 483 točk). Dijaki, ki se na Finskem glede na indeks uvrščajo v zgornjo četrtino, pa so na testu v povprečju dosegli kar 58I točk.

Rezultati kažejo, da je pripisovanje največje pomembnosti strategijam razumevanja in pomnjenja besedila zaznati pri dijakih na Finskem, najmanjše pa na Norveškem. Vrednosti indeksov strategij razumevanja in pomnjenja besedila so v vseh treh primerjanih državah $v$ primerjavi s povprečjem držav OECD relativno nizke. Vendar, dijaki, ki ocenjujejo strategije pomnjenja in razumevanja kot pomembne, $v$ vseh treh državah v povprečju dosegajo tudi višje dosežke na testu bralne pismenosti. Na podlagi podatkov o deležih pojasnjene variabilnosti na podlagi omenjenega indeksa pa opazimo tudi, da so strategije razumevanja in pomnjenja besedila pomemben dejavnik pri pojasnjevanju bralnih dosežkov tako $v$ Sloveniji kot v severnih državah.

Metakognitivne strategije: indeks strategijpovzemanja besedila

Zaznavanje uporabnosti strategij povzemanja besedila so v raziskavi PISA 2009 ugotavljali z vprašanjem, kjer je bila na začetku opisana bralna naloga:

Pravkar si prebral/-a dve strani dolgo in precej zahtevno besedilo o spreminjanju vodne gladine jezera $v$ Afriki. Napisati moraš povzetek.

Sledilo je vprašanje:

Kako ocenjuješ uporabnost naslednjih strategij za pisanje povzetka tega dve strani dolgega besedila?

Možne strategije, ki so jih ocenjevali dijaki, so bile naslednje: 
a) Napišem povzetek. Nato preverim, ali je vsak odstavek vključen v povzetek, ker mora biti vključena vsebina vsakega odstavka.

b) Pravilno poskušam prepisati čim več stavkov.

c) Preden napišem povzetek, čim večkrat preberem besedilo.

d) Natančno preverim, ali so v povzetku predstavljena najpomembnejša dejstva.

e) Preberem besedilo in podčrtam najpomembnejše stavke. Nato jih s svojimi besedami napišem kot povzetek.

Udeleženci so na trditve odgovarjali s 6-stopenjsko lestvico, pri čemer I pomeni »Sploh ni uporabna $\ll$ in 6 »Zelo je uporabna «.

Strategiji d in e sta v raziskavi PISA 2009 označeni kot najbolj učinkoviti strategiji, strategiji a in c kot srednje učinkoviti ter strategija b kot najmanj učinkovita strategija povzemanja besedila.

Indeks strategij za razumevanje in pomnjenje besedila je standardizirana vrednost $s$ povprečjem $\circ$ in standardnim odklonom I. Višje vrednosti indeksa pomenijo, da dijaki ocenjujejo večjo pomembnost strategij povzemanja besedila, sploh tistih, ki so učinkovitejše. Med tremi primerjanimi državami ima najvišji indeks strategij povzemanja besedila Norveška; vrednost indeksa je nad povprečjem držav OECD, in sicer o, 13. Sledi ji Finska $(0,08)$, pri slovenskih dijakih pa je povprečni indeks znašal -0,19 in je pod povprečjem držav OECD. Torej, države, ki so na testu bralne pismenosti uspešnejše, imajo tudi dijake, kiv splošnem vedo, kako ucinkovito povzemati informacije in se zavedajo pomembnosti omenjenih strategij $v$ procesu učenja. To potrjujejo tudi podatki o bralnih dosežkih dijakov, ki se uvrščajo v najvišje in najnižje četrtine vrednosti indeksa strategij povzemanja besedila. Razlike med dosežki dijakov v najnižji in najvišji četrtini vrednosti indeksa v Sloveniji znašajo kar 103 točke (432 proti 535 točk), na Finskem Io8 točk (473 proti 58 I točk) ter na Norveškem 98 točk ( 447 proti 545 točk).

Tudi deleži pojasnjene variabilnosti, ki jo lahko v vseh treh državah z omenjenim indeksom pojasnimo, kažejo na pomembnost dejavnika strategij povzemanja besedila pri pojasnjevanju bralnih dosežkov na testu PISA. Največ variabilnosti v bralnih dosežkih lahko z omenjenim indeksom pojasnimo na Finskem (23,6 \%), temu pa sledita Slovenija (2 I,3 \%) in Norveška (19,8 \%). V povprečju držav OECD lahko 2I, I \% variabilnosti v bralnih dosežkih na PISA 2009 pojasnimo z indeksom strategij povzemanja besedila. Eno enoto višje vrednosti omenjenega indeksa so na povprečni ravni držav OECD povezane z za 4I,9 točk (v Sloveniji pa z za 39,7 točk) višjimi dosežki na lestvici bralnih dosežkov, na Finskem 
z za 42,4 in na Norveškem z za 4I,4 točk. Prirast 39 točk na ravni držav OECD pomeni povprečen napredek I 5 -letnika v branju v enem šolskem letu.

\section{Učne strategije: memoriranje, elaboracija, kontrolne strategije}

PISA 2009 meri tako učne strategije pomnjenja kot metakognitivni vidik teh strategij: na eni strani meri, v kolikšni meri dijaki uporabljajo strategije pomnjenja, na drugi strani pa zavedanje dijakov, katere strategije so najpomembnejše za pomnjenje informacij. Oba vidika strategij sta tesno povezana, vendar merita različne načine, na katere dijaki uskladiščijo informacije v spomin. »Metakognitivni« indeks strategij razumevanja in pomnjenja pomeni, v kolikšni meri znajo dijaki uskladiščiti informacije, jih povezati s preteklim znanjem in jih elaborirati do te mere, da znajo pridobljeno znanje uporabiti v novi situaciji. Indeks strategij memoriranja pa meri, kako pogosto dijaki uporabljajo tehnike zapomnitve, pri čemer se nova informacija uskladišči v spomin brez nadaljnje elaboracije. PISA 2009 proučuje tri vrste učnih strategij: memoriranje, elaboracijo in kontrolne strategije. Strategije ocenjuje dijak na 4-stopenjski lestvici ( $\mathrm{I}=$ Skoraj nikoli, $2=$ Včasih, 3 = Pogosto, $4=$ Skoraj vedno). Izhodiščno vprašanje se glasi:

Kako pogosto počneš naslednje, ko se učiš?

Različne strategije se združujejo v tri indekse:

a) Indeks strategij memoriranja ugotavlja, v kolikšni meri si dijaki skušajo zapomniti nove informacije, da bi jih kasneje lahko obnovili na glas, in kako pogosto se učijo tako, da znova in znova berejo učno besedilo.

Trditve, ki sestavljajo ta indeks, so naslednje:

Ko se učim, si poskušam zapomniti vse, kar je napisano v besedilu.

Ko se učim, si poskušam zapomniti čim več podrobnosti.

Ko se ucim, preberem besedilo tolikokrat, da ga znam recitirati.

Ko se ucim, znova in znova preberem besedilo.

b) Indeks strategij elaboracije ugotavlja, ali si dijaki prizadevajo razumeti učno gradivo tako, da ga povežejo s tem, kar že vedo, ali si prizadevajo povezovati novo učno gradivo $\mathrm{z}$ informacijami, ki se jih učijo pri drugih predmetih, in ali skušajo ugotoviti uporabnost informacij v resničnosti.

Trditve, ki sestavljajo ta indeks, so naslednje:

Ko se učim, poskušam povezati nove informacije z znanjem, ki sem ga predhodno pridobil/-a pri drugih predmetih.

Ko se učim, poskušam ugotoviti, kako bi bile informacije labko koristne zunaj šole. 
Ko se učim, ugotavljam, kako se informacije iz besedila ujemajo stem, kar se dogaja $v$ resničnem življenju.

c) Indeks kontrolnih strategij ugotavlja zavedanje dijakov, katerih pojmov kljub prebranemu še vedno ne razumejo; ali se prepričajo, da si res zapomnijo bistvene informacije iz besedila in ali iščejo dodatne informacije, da bi pojasnili tisto, česar ne razumejo dobro.

Trditve, ki sestavljajo ta indeks, so naslednje:

Ko se učim, najprej ugotovim, kaj je tisto, kar se moram naučiti.

Ko se ucim, preverim, ali razumem, kar sem prebral/-a.

Ko se učim, poskušam ugotoviti, katerih pojmov še vedno ne razumem.

Ko se učim, poskrbim, da si zapomnim najpomembnejše točke $v$ besedilu.

Ko se učim in nečesa ne razumem, poišcem dodatne informacije, skaterimi si to razjasnim.

$\mathrm{Na}$ ravni držav OECD, kjer je korelacija med memoriranjem in elaboracijo $r=0,4 \mathrm{I}$, med memoriranjem in kontrolnimi strategijami $r=0,55$ in med elaboracijo in kontrolnimi strategijami $r=0,55$, rezultati raziskave kažejo, da v državah, ki so na lestvici bralne pismenosti dokaj visoko, Is-letniki uporabljajo strategije memoriranja, elaboracije in kontrolne strategije v manjši meri kot njihovi vrstniki v ostalih državah OECD. Podobno je na primer zaslediti tudi na Finskem in Norveškem, kjer kontrolne strategije niso pogosto zastopane med učenci.

Rezultati kažejo, da so strategije memoriranja (dobesedna zapomnitev naučenega, učenje podrobnosti, učenje na pamet) pri dijakih na Norveškem (vrednost indeksa strategij memoriranja znaša -0,44) in Finskem $(-0,25)$ bistveno manj prisotne, kot se je to pokazalo na povprečni ravni držav $\operatorname{OECD}(0,00)$ in tudi v Sloveniji $(0,06)$.

Rezultati tudi kažejo, da uspešnejši učenci v vseh treh državah uporabljajo manj strategij memoriranja naučenega kot njihovi učno manj uspešni vrstniki. Slovenski dijaki, ki so se uvrstili v spodnjo četrtino indeksa strategij memoriranja, so dosegli največ točk ( $5 \circ \mathrm{I}), \mathrm{v}$ zgornji četrtini indeksa pa so dosežki dijakov nižji za 39 točk (462 točk). Podobno stanje je opaziti na Finskem ( 534 proti 536 točk) in tudi Norveškem (499 proti 502 točk).V povprečju držav OECD lahko I,I \% variabilnosti v bralnih dosežkih na PISA 2009 pojasnimo z indeksom strategij memoriranja. V Sloveniji je odstotek pojasnjene variance nekoliko nad povprečjem (2,8 \%), na Finskem in Norveškem pa pod povprečjem (Finska o, I \% in Norveška 0,2 \%). 
Zanimivi so tudi podatki za povprečni indeks strategij elaboracije, še posebej morda za Finsko in Norveško, kjer se vrednosti indeksa gibljeta pod povprečjem držav OECD (-o, I 5 za Finsko in -0,08 za Norveško). Povprečni indeks strategij elaboracije pa je v Sloveniji nadpovprečen $(0,20)$, kar pomeni, da slovenski dijaki v nekoliko višji meri uporabljajo strategije povezovanja novega učnega gradiva z že znanim in drugimi šolskimi predmeti ter strategije iskanja uporabnosti novonaučene snovi kot njihovi vrstniki na Finskem in Norveškem, državah, ki se na testu bralne pismenosti uvrščata nad povprečje držav OECD oziroma v sam vrh.

Tudi drugi podatki kažejo na šibko pozitivno povezanost med uporabo strategij elaboracije in bralnimi dosežki. Razlika med dijaki, ki se po rezultatu indeksa elaboracije uvrščajo v spodnjo četrtino indeksa, ter dijaki, ki se uvrščajo v zgornjo četrtino indeksa, je I 2 točk ( 482 proti 494 točk). Na Finskem dosegajo dijaki v zgornji četrtini indeksa celo slabše bralne dosežke od dijakov, ki se uvrščajo v spodnjo četrtino vrednosti indeksa strategij elaboracije ( 523 proti 5 I 5 točk), na Norveškem pa omenjena razlika znaša 29 točk (485 proti 514 točk).V povprečju držav OECD lahko I, I \% variabilnosti v bralnih dosežkih na testu bralne pismenosti pojasnimo z indeksom strategij elaboracije, v Sloveniji pa o,9 \%. Na Finskem in Norveškem sta odstotka nekoliko višja, in sicer 2, I \% in 3,3\%.

Največje razlike so se znotraj primerjanih držav pokazale na ravni uporabe kontrolnih strategij. V Sloveniji je povprečni indeks kontrolnih strategij nekoliko višji (0,15), kot je ta na ravni povprečja OECD (o,oo), na Finskem in Norveškem pa je omenjeni indeks precej pod povprečjem (Finska-0,34; Norveška -0,42). Iz omenjenih vrednosti indeksa je razbrati, da so $v$ Sloveniji kontrolne strategije bolj prisotne kot v ostalih dveh državah, ki sta se na testu bralne pismenosti bolje odrezali. V vseh treh državah pa se je pokazalo, da dijaki, ki se z rezultatom na indeksu uvrščajo v zgornjo četrtino, v povprečju dosegajo tudi višje bralne dosežke. Slovenski dijaki, ki so se uvrstili v spodnjo četrtino indeksa kontrolnih strategij, so dosegli 449 točk na testu bralne pismenosti, najvišje bralne dosežke ( 5 I 5 točk) pa so dosegli dijaki v zgornji četrtini vrednosti indeksa. Tudi na Finskem in Norveškem je opaziti podobno stanje (Finska - 503 proti 565 točk; Norveška - 469 proti 532 točk).V povprečju držav OECD lahko 8,2 \% variabilnosti v bralnih dosežkih na testu PISA 2009 pojasnimo $\mathrm{z}$ indeksom kontrolnih strategij. V Sloveniji je odstotek pojasnjene variance nižji, tj. 6,4 \%, na Finskem in Norveškem pa 8,1 \% ter 7,5\%.V povprečju so v državah OECD eno enoto višje vrednosti omenjenega indeksa povezane z 26, I točkami višjimi dosežki na lestvici bralnih dosežkov, v Sloveniji, na Finskem in Norveške pa podobno, z 24, 25,6 in 25,7 točkami. 
V okviru učnih strategij je tako opaziti neke vrste preobrat na področju strategij memoriranja, elaboracije in kontrolnih strategij. Rezultati kažejo, da so vse omenjene strategije pri dijakih na Finskem in Norveškem v povprečju manj prisotne kot pri I 5 -letnikih v Sloveniji in na povprečni ravni držav OECD, saj so vrednosti vseh treh indeksov tako za Finsko kot Norveško v nasprotju s Slovenijo podpovprečne. Sicer je opaziti podobne negativne učinke strategij memoriranja na bralne dosežke ter pozitivne učinke strategij elaboracije in kontrolnih strategij znotraj vseh treh držav, vendar je povezanost kot tudi moč pojasnjevanja bralnih dosežkov na podlagi omenjenih strategij v vseh primerjanih državah šibka.

\section{Stališca do sole in pouka}

Stališča do šole in pouka materinščine

Stališča dijakov do šole in pouka so v raziskavi PISA 2009 opredeljena z naslednjimi področji in pripadajočimi indeksi:

- $\quad$ zaznano disciplino pri pouku materinščine (Indeks discipline v razredu pri pouku materinščine),

- $\quad$ zaznano učiteljevo spodbudo dijakov $\mathrm{k}$ aktivni udeležbi pri bralnih aktivnostih (Indeks zaznane učiteljeve spodbude) ter

- zaznanim dijakovim pozitivnim odnosom s strani učiteljev (Indeks zaznanega pozitivnega odnosa učiteljev do dijaka).

Opis rezultatov zajema primerjavo vrednosti posameznega indeksa z bralnimi dosežki dijakov ter variabilnost omenjenega indeksa znotraj šol in med šolami, tako na ravni držav OECD kot v Sloveniji. Ker nas je zanimalo tudi, kakšna je variabilnost v dosežkih na testu bralne pismenosti glede na socialno-ekonomski status ter spol slovenskih dijakov, dodajamo ob koncu razdelka še te opise.

V splošnem rezultati raziskave PISA 2009 na mednarodni ravni kažejo, da dijaki, ki obiskujejo šole, kjer so vzpostavljeni pozitivnejši odnosi med učitelji in dijaki, kjer učitelji bolj spodbujajo dijake $k$ aktivnemu sodelovanju pri pouku materinšcine in kjer je tudi boljša disciplina, dosegajo višje dosežke na testu bralne pismenosti. Omenjene povezave veljajo tudi ob upoštevanju socialno-ekonomskega statusa dijakov (OECD, 20roč). Tudi tukaj je potrebno poudariti, da rezultati nakazujejo le smer in moč povezanosti med omenjenimi dejavniki ter bralnimi dosežki in o vzročno-posledičnih odnosih ne moremo govoriti. Stališča do šole in pouka so le eden izmed dejavnikov, ki lahko učinkujejo na dosežke dijaka na testu bralne pismenosti, saj je ta rezultat več, tudi še nepojasnje- 
nih, dejavnikov, ki se med seboj dopolnjujejo in prepletajo. Pa tudi učinkov stališč do šole in pouka na uspeh pri branju, $s$ pomočjo vprašanj uporabljenih v raziskavi, ne moremo v celoti pojasniti.

Ob tem je pomembno poudariti, da raziskava PISA med drugim ne vključuje vprašalnika za učitelje, s pomočjo katerega bi lahko področje stališč do šole in pouka še podrobneje raziskali. Opozoriti pa je treba tudi, da so ocene učinkov omenjenih dejavnikov podane na podlagi osebne zaznave dijakov in niso izmerjene s pomočjo objektivnega merila ter predstavljajo le subjektivno oceno stanja v določenem trenutku. Tako lahko na odgovore dijaka učinkujejo številni trenutni dejavniki, kot je slabše počutje, kratkotrajen konflikt z določenim profesorjem, odgovarjanje v skladu s tem, kar je med vrstniki in nasploh družbeno sprejemljivo ipd.

\section{Indeks discipline v razredu pri pouku materinšcine}

Disciplina v razredu pomembno učinkuje na učni proces pri določenem predmetu, tako z vidika učitelja kot učenca. Razredi, kjer mora učitelj veliko časa posvetiti vzpostavljanju discipline, so pogosto tudi manj učinkoviti z vidika kakovosti poučevanja, saj učitelj veliko časa porabi že za to, da lahko s poučevanjem sploh prične. Več disciplinskih težav pa ima negativen učinek tudi na dijake v smislu zavzetosti, pozornosti, sledenja in sodelovanja pri pouku. Vse to se posledično odraža na slabših učnih dosežkih dijakov (Gamoran in Nystrand v OECD, 201оč).

V raziskavi PISA 2009 so zaznano disciplino pri pouku preverjali z naslednjim vprašanjem in pripadajočimi trditvami, ki tvorijo indeks discipline v razredu:

Kako pogosto se pri pouku materinšcine zgodi naslednje?

I Dijaki ne posluśajo profesorjal-ice.

2 Vucilnici sta brup in nered.

3 Profesor/-ica mora dolgo čakati, da se dijaki umirijo.

4 Dijaki ne morejo dobro delati.

5 Dijaki še dolgo po tem, ko se je pouk začel, ne začnejo delati.

Dijaki so s pomočjo zgoraj omenjenih postavk ocenjevali pogostnost pojavljanja disciplinskih težav med poukom materinščine. Ocene postavk tvorijo že omenjeni indeks zaznane discipline v razredu, pri katerem vrednost o predstavlja povprečje držav OECD in I standardni odklon od tega povprečja. Višje, pozitivne vrednosti indeksa predstavljajo boljšo disciplino v razredu. Povprečna vrednost indeksa za Slovenijo je -o, I I, kar pomeni, da slovenski dijaki v povprečju zaznavajo slabšo disciplino pri pouku slovenščine kot v pov- 
prečju njihovi vrstniki v državah OECD. Na Finskem in Norveškem je slika še slabša, saj se povprečni vrednosti indeksa gibljeta še nižje pod povprečjem (Finska - -0,29; Norveška - -0,24). Dijaki na Finskem in Norveškem tako pri pouku materinščine zaznavajo slabso disciplino kot dijaki v Sloveniji in drugih državah OECD.

Tabela 7: Odstotek dijakov, ki so na trditve o disciplini pri pouku materinščine odgovorili z

»Nikoli ali zelo redko « in »Pri nekaterih urah «

\begin{tabular}{|c|c|c|c|c|c|}
\hline & I & 2 & 3 & 4 & 5 \\
\hline \multicolumn{6}{|l|}{ Finska } \\
\hline$\%$ dijakov & 60,0 & 52,0 & 63,0 & 80,0 & 68,0 \\
\hline \multicolumn{6}{|l|}{ Norveška } \\
\hline$\%$ dijakov & 67,0 & 61,0 & 66,0 & 77,0 & 67,0 \\
\hline \multicolumn{6}{|c|}{ Povprečje OECD } \\
\hline$\%$ dijakov & 71,0 & 68,0 & 72,0 & $8 \mathrm{I}, \mathrm{O}$ & 75,0 \\
\hline \multicolumn{6}{|l|}{ Slovenija } \\
\hline \% dijakov & 59,0 & 66,0 & 68,0 & 78,0 & 70,0 \\
\hline
\end{tabular}

Številke I-5 označujejo zaporedne številke trditev, ki so prikazane v besedilu pred tabelo.

$\mathrm{Z}$ indeksom zaznane discipline $\mathrm{v}$ razredu lahko $\mathrm{v}$ povprečju držav OECD pojasnimo 2,6 \% variabilnosti v bralnih dosežkih, v Sloveniji pa 5,2 \%, kar je v primerjavi z drugimi državami OECD med višjimi odstotki. Na Finskem in Norveškem lahko z omenjenim indeksom pojasnimo bistveno manjši delež variabilnosti v bralnih dosežkih, in sicer $0,2 \%$ (Finska) in 2,1 \% (Norveška).

Če pogledamo povezanost omenjenega indeksa z bralnimi dosežki, opazimo, da v vseh treh primerjanih državah vrednost indeksa z višjimi bralnimi dosežki narašča. Razlika v bralnih dosežkih slovenskih dijakov, ki se glede na vrednost indeksa uvrščajo v spodnjo četrtino $(-1,28)$ in tistimi, ki se uvrščajo v zgornjo četrtino vrednosti indeksa $(\mathrm{I}, 17)$, je 56 točk (460 proti 516 točk). Na Finskem in Norveškem so te razlike manjše, in sicer I 4 točk na Finskem ( 532 proti 516 točk) in 32 točk na Norveškem. Dijaki iz vseh treh primerjanih držav, ki so na testu branja dosegli boljše rezultate, pri pouku materinšcine zaznavajo manj disciplinskih težav kot njihovi manj uspešni vrstniki, vendar so razlike manjše in glede na delež variabilnosti v dosežkih, ki jo labko pojasnimo z indeksom zaznane discipline, labko rečemo, da je moč pojasnjevanja bralnih dosežkov strani omenjenega dejaunika sibka. 


\section{Indeks zaznane uciteljeve spodbude pri bralnih aktivnostih}

Dijaki, ki se pri pouku maternega jezika aktivno vključujejo v proces učenja in katere snov tudi zanima, se naučijo mnogo več kot tisti, ki le sledijo podanim navodilom in pravilom ter za poučevano snov ne izkazujejo večjega osebnega zanimanja. Tudi interakcija med dijakom in učiteljem bistveno prispeva $\mathrm{k}$ zanimanju dijakov za snov ter $\mathrm{k}$ njihovi aktivni udeležbi pri pouku. Še posebej k temu pripomore učiteljevo spodbujanje dijakov v smislu povezovanja njihovih poprejšnjih odgovorov s podvprašanji, ki na koncu vodi v diskusijo (Nystrand in Gamoran v OECD, 2009č).

$\mathrm{V}$ raziskavi PISA 2009 so dijaki podali svojo oceno učiteljeve spodbude pri bralnih aktivnostih $s$ pomočjo naslednjega vprašanja in pripadajočih postavk:

Kako pogosto se pri pouku materinšcine zgodi naslednje?

I Profesor-ica od dijakov zahteva, da pojasnijo pomen besedila.

2 Profesor-ica postavlja vprašanja, ki dijake spodbujajo k boljšemu razumevanju besedila.

3 Profesor-ica da dijakom dovolj časa, da razmislijo o odgovorih.

4 Profesor-ica priporoči v branje knjigo ali avtorja.

5 Profesor-ica spodbuja dijake, da izrazijo svoje mnenje o besedilu.

6 Profesor/-ica nam pomaga povezati zgodbe, ki jih beremo, z nasim življenjem.

7 Profesor-ica nam pokaže, kako informacije iz besedil nadgrajujejo tisto, kar že vemo.

Tabela 8: Odstotek dijakov, ki so na trditve o spodbudi s strani učitelja odgovorili s »Pri večini ur $\ll$ in Pri vseh urah $\ll$

\begin{tabular}{|c|c|c|c|c|c|c|c|}
\hline & $\mathrm{I}$ & 2 & 3 & 4 & 5 & 6 & 7 \\
\hline \multicolumn{8}{|l|}{ Finska } \\
\hline$\%$ dijakov & 35,0 & 35,0 & 63,0 & 38,0 & 47,0 & 17,0 & 24,0 \\
\hline \multicolumn{8}{|l|}{ Norveška } \\
\hline$\%$ dijakov & 45,0 & 53,0 & 47,0 & 28,0 & 41,0 & 20,0 & 28,0 \\
\hline \multicolumn{8}{|c|}{ Povprečje OECD } \\
\hline$\%$ dijakov & 52,0 & 59,0 & 60,0 & 36,0 & 55,0 & 33,0 & 43,0 \\
\hline \multicolumn{8}{|l|}{ Slovenija } \\
\hline$\%$ dijakov & 63,0 & 68,0 & 62,0 & 41,0 & 65,0 & 46,0 & 48,0 \\
\hline
\end{tabular}

Številke $1-7$ označujejo zaporedne številke trditev, ki so prikazane v besedilu pred tabelo. 
V državah OECD velik odstotek dijakov poroča o tem, da jih učitelji spodbujajo $\mathrm{k}$ njihovi aktivni udeležbi pri branju. Tako jih v povprečju kar $60 \%$ meni, da jim da učitelj dovolj časa za razmislek o odgovorih, in kar $59 \%$ jih poroča, da jih učitelj spodbuja k boljšemu razumevanju besedila. V Sloveniji so ti odstotki še višji, saj v povprečju kar $68 \%$ dijakov poroča o tem, da jih učitelji spodbujajo k boljšemu razumevanju besedila, in tudi odstotek tistih, ki menijo, da jim da učitelj dovolj časa za razmislek o odgovorih, je višji (62 \%). Na Finskem in Norveškem je slika nekoliko drugačna. Tako Finci kot Norvežani se skoraj v vseh postavkah (razen tretje), uvrščajo pod povprečje držav OECD. Tako le 35 \% I5-letnikov na Finskem poroča o tem, da profesorica od njih zahteva, da pojasnijo besedilo in jim zastavlja vprašanja, ki jih spodbujajo $\mathrm{k}$ boljšemu razumevanju besedila. Odstotka dijakov, ki menijo enako, sta na Norveškem nekoliko višja ( $53 \%$ in $45 \%$ ), vendar še vedno pod povprečjem držav OECD ( $59 \%$ in $52 \%)$ in nižja od odstotka omenjenih dijakov v Sloveniji (62 \% in $68 \%$ ). V povprečju kar $65 \%$ slovenskih dijakov poroča tudi o tem, da jih učitelji spodbujajo k izražanju svojega mnenja, kar je ıo \% več, kot je bilo to ugotovljeno na povprečni ravni držav OECD ( $55 \%$ in $24 \%$ ter I 8 \% več kot na Norveškem in Finskem. Naši učenci pa tudi v večji meri (46\% in $48 \%)$ menijo, da jim učitelj pomaga prebrano povezati z njihovim vsakdanjim življenjem ter prejšnjim znanjem, kot o tem poročajo njihovi vrstniki na ravni OECD držav ( $33 \%$ in $43 \%$ ) in tudi na Finskem ( $17 \%$ in $24 \%$ ) ter Norveškem (20\% in $28 \%$ ), kjer sta odstotka I 5 -letnikov, ki o tem poročajo, dokaj nizka. $V$ našem prostoru tako dijaki v povprečju zaznavajo večjo spodbudo ucitelja $k$ zavzetosti in aktivni udeležbi pri branju, kot je bilo to ugotovljeno pri sovrstnikih na Finskem in Norveskem.

$V$ splošnem labko rečemo, da Is-letniki na Finskem in Norveškem v povprečju zaznavajo manj spodbude strani učitelja kot dijaki v Sloveniji in na povprečni ravni OECD držav. Povprečna vrednost indeksa zaznane učiteljeve spodbude pri bralnih aktivnostih Indeksa je na Finskem -0,33 in na Norveškem podobno, -0,37 (Slovenija - 0,22). Dijaki, ki v največji meri poročajo o spodbudi pri bralnih aktivnostih s strani učitelja, v povprečju ne dosegajo bistveno višjih dosežkov od tistih dijakov, ki poročajo o manjši spodbudi. V Sloveniji so razlike v dosežkih med omenjenimi dijaki bistveno večje. Torej, spodbuda pri bralnih aktivnostih s strani učitelja nima tako velikega učinka na bralne dosežke kot pri nas.

$\mathrm{Z}$ indeksom zaznanega učiteljevega spodbujanja učencev pri bralni aktivnosti lahko v Sloveniji pojasnimo I,4 \% variabilnosti v bralnih dosežkih, na ravni držav OECD pa o,7 \%. Tudi na Finskem in Norveškem je delež pojasnjene variabilnosti nižji kot v Sloveniji, in sicer 0,1 \% na Finskem in 0,9 \% na Norveškem. Če v vseh treh državah indeks primerjamo 
z bralnimi dosežki, opazimo, da je indeks pri učencih z višjimi dosežki višji in pri učencih z nižjimi nižji, vendar razlike predvsem na Finskem in Norveškem niso tako velike. Razlika v bralnih dosežkih slovenskih dijakov, ki se glede na vrednost indeksa uvrščajo v spodnjo četrtino $(-0,95)$, in tistimi, ki se uvrščajo v zgornjo četrtino vrednosti indeksa $(1,38)$, je 30 točk (467 proti 497 točk), kar pa je razlika, ki predstavlja učence na različnih ravneh bralne pismenosti. Ta razlika je tudi večja kot na povprečni ravni držav OECD (484 proti 502 točk) in tudi na Finskem ( 6 točk; 536 proti 542 točk) ter na Norveškem ( 18 točk; 496 proti 5 I 4 točk).

Kot lahko razberemo iz podatkov, v povprečju v vseh treh državah dijaki, ki poročajo o večji učiteljevi spodbudi pri bralnih aktivnostih, dosegajo tudi višje dosežke na testu bralne pismenosti, vendar so te razlike na Finskem in Norveškem, ki sta se na lestvici bralne pismenosti uvrstili nad povprečje OECD držav oz. v sam vrh, v primerjavi s Slovenijo relativno majhne.

Dijaki pa so poleg postavk, ki tvorijo indeks zaznanega učiteljevega spodbujanja učencev k zavzetosti in aktivni udeležbi pri bralnih aktivnostih, odgovarjali še na vprašanje, ki podrobneje opisuje pouk materinščine $\mathrm{z}$ vidika jasnosti in transparentnosti učnega procesa in ocenjevanja ter spodbujanja dijakov $\mathrm{k}$ aktivnemu sodelovanju pri pouku.

Dijaki so omenjeno ocenjevali s pomočjo naslednjega vprašanja in pripadajočih postavk:

Kako pogosto se pri pouku materinščine zgodi naslednje?

I Profesor/-ica vnaprej razloži, kaj pričakuje od dijakov.

2 Profesor/-ica preveri, ali so dijaki pri reševanju bralne naloge zbrani.

3 Profesor/-ica se po tem, ko so končali reševanje bralne naloge, z dijaki pogovori o njihovem delu.

4 Profesor/-ica dijakom vnaprej pove, kako bo vrednotil/-a njihovo delo.

5 Profesor/-ica vpraša, ali so vsi dijaki razumeli, kako morajo rešiti bralno nalogo.

6 Profesor-ica oceni dijakovo delo.

7 Profesor/-ica da dijakom možnost, da postavljajo vprašanja o bralni nalogi.

8 Profesor/-ica postavlja vprašanja, ki dijake spodbujajo k aktivnemu sodelovanju.

9 Profesor/-ica dijakom takoj po tem, ko so končali bralno nalogo, pove, kako uspešni so bili.

Omenjene postavke niso bile vključene v izračun indeksa, ki bi bil mednarodno primerljiv, lahko pa nam služijo kot grob opis zaznave dijakov o tem, v kolikšni meri je pouk slovenščine transparenten in v kolikšni meri učitelji dijake spodbujajo k aktivnemu sode- 
Tabela 9: Odstotek dijakov, ki so na trditve o transparentnosti učnega procesa in ocenjevanja odgovorilis » Pri večini ur « in »Pri vseh urah «

\begin{tabular}{|c|c|c|c|c|c|c|c|c|c|}
\hline & I & 2 & 3 & 4 & 5 & 6 & 7 & 8 & 9 \\
\hline \multicolumn{10}{|l|}{ Finska } \\
\hline$\%$ dijakov & 27,5 & 56,2 & 44,5 & 58,6 & 58,4 & 70,8 & 68,4 & 46,2 & 25,5 \\
\hline \multicolumn{10}{|l|}{ Norveška } \\
\hline$\%$ dijakov & 31,0 & $4 \mathrm{I}, \mathrm{I}$ & 48,9 & 44,9 & 41,6 & 50,6 & 58,9 & 46,3 & 37,7 \\
\hline \multicolumn{10}{|c|}{ Povprečje OECD } \\
\hline \% dijakov & 47,0 & 58,5 & 55,4 & 57,2 & 62,4 & 62,0 & 67,8 & 55,0 & 39,6 \\
\hline \multicolumn{10}{|l|}{ Slovenija } \\
\hline$\%$ dijakov & 49,3 & 46,4 & 57,6 & 59,0 & 61,9 & 41,7 & 59,4 & 61,5 & 39,6 \\
\hline
\end{tabular}

Številke I-9 označujejo zaporedne številke trditev, ki so prikazane v besedilu pred tabelo.

lovanju. Tudi v tem primeru je približno dve tretjini slovenskih dijakov poročalo o tem, da jih učitelj pri večini ur spodbuja k aktivnemu sodelovanju pri pouku, kar je $6 \%$ dijakov več kot v povprečju na ravni držav OECD ( $55 \%$ ) in približno is \% več, kot o tem poročajo dijaki na Finskem (46,2 \%) in Norveškem (46,3 \%). Približno enak odstotek $(59,4 \%)$ slovenskih dijakov meni tudi, da jim učitelj pri večini ali pri vseh urah daje možnost postavljanja vprašanj o bralni nalogi, kar pa predstavlja približno $9 \%$ manj, kot se je to izkazalo na povprečni ravni držav OECD $(67,8 \%)$. Tudi Norveška se v tem pogledu podobno kot Slovenija uvršča pod povprečje držav OECD ( $58,9 \%)$, Finska pa se giblje okrog povprečja $(68,4 \%)$. Približno polovica slovenskih dijakov tudi meni, da učitelj vnaprej razloži, kaj od njih pričakuje, in da se tudi po koncu reševanja naloge pogovori o njihovem delu. Oba odstotka sta v teh primerih višja kot v povprečju držav OECD $(49,3$ $\%$ in $57,6 \%$ proti $47,0 \%$ in $55,4 \%$ ), odstotki finskih $(27,5 \%$ in $44,5 \%)$ in norveških ( 3 I $\%$ in $48,9 \%$ ) vrstnikov, ki menijo podobno, pa so tudi pri teh postavkah nižji od povprečja držav OECD.

Omenjeni podatki nakazujejo, da najverjetneje obstajajo razlike vpojmovanju učiteljeve spodbude pri pouku med slovenskimi dijaki in njihovimi vrstniki iz severnih držav. Vendar pa kljub temu, da slednji poročajo o slabši zaznani podpori strani učitelja (kot jo merimo z vključenimi postavkami), v povprečju dosegajo precej boljše rezultate na testu bralne pismenosti kot dijaki $v$ Sloveniji in na povprećni ravni držav OECD. 
Indeks zaznanega pozitivnega odnosa ućiteljev do dijaka

Pozitiven odnos med učiteljem in učencem je bistven za vzpostavljanje učinkovitega učnega okolja. Odnos učenca z učiteljem so številni avtorji že proučili iz najrazličnejših vidikov. Tako je dobro pojasnjena pozitivna povezanost učiteljevega vrednotenja izobraževanja in lastnega vrednotenja izobraževanja pri učencu (Murdock in Anderman, 2000), pa tudi učinek akademske opore in spodbude s strani učitelja na učno motivacijo ter posledično na učne dosežke posameznika (Regner et al., 2009). Tudi v našem prostoru sta M. Puklek Levpušček in M. Zupančič (Puklek Levpušček in Zupančič, 2009) ugotovili, da se sprejemanje $s$ strani učitelja in pohvala po uspešno opravljenem delu pomembno pozitivno povezujeta z zaznano učno samoučinkovitostjo učenca ter posledično z njegovo učno uspešnostjo. Raziskave kažejo tudi, da ima učno okolje, v katerem učenec zaznava, da se učitelj skupaj z njim trudi dosegati boljše rezultate in je med njima vzpostavljen pozitiven odnos, ugoden učinek predvsem na učence, ki dosegajo slabše učne rezultate. $\mathrm{V}$ takem okolju je bilo ugotovljenih manj disciplinskih težav, tovrstni učenci pa so poročali, da se naučijo več (Gamoran, 1993, v OECD, 2010č).

Tudi v raziskavi PISA 2009 so dijaki ocenjevali odnos učiteljev do njih samih. Trditve, $s$ pomočjo katerih so odnos ocenjevali, vključujejo oceno zanimanja učiteljev za njihovo dobrobit, oporo s strani učiteljev, pripravljenost prisluhniti in pravično obravnavanje s strani učiteljev. Odgovori na tovrstna vprašanja tvorijo povprečni indeks zaznanega pozitivnega odnosa učiteljev do dijaka, ki nam omogoča primerljivost z ostalimi državami OECD. Povprečje indeksa na ravni držav OECD ima vrednost o s standardnim odklonom I, vrednosti indeksa za posamezno državo pa predstavljajo odklone od tega povprečja v pozitivno ali negativno smer. Pozitivnejša in višja vrednost povprečnega indeksa nakazuje na pozitivnejši zaznan odnos učiteljev do dijaka.

Vprašanje ter pripadajoče trditve, ki tvorijo indeks zaznanega pozitivnega odnosa učiteljev do učenca, so naslednje:

Koliko se strinjašz naslednjimi trditvami o učiteljih na tvoji šoli?

I Dobro se razumem z vecino učiteljev.

2 Večino učiteljev zanima, ali se dobro počutim.

3 Večina učiteljev pozorno posluša, kaj jim hočem povedati.

4 Če potrebujem dodatno pomoč, mi jo moji učitelji ponudijo.

5 Večina učiteljev me obravnava pravično. 
Tabela ıo: Odstotek dijakov, ki so na trditve o odnosu učiteljev do njih odgovorili s »Strinjam se $\ll$ in $\gg$ Popolnoma se strinjam $\ll$

\begin{tabular}{|c|c|c|c|c|c|}
\hline & $\mathrm{I}$ & 2 & 3 & 4 & 5 \\
\hline \multicolumn{6}{|l|}{ Finska } \\
\hline$\%$ dijakov & 87,0 & 49,0 & 63,0 & 84,0 & 80,0 \\
\hline \multicolumn{6}{|l|}{ Norveška } \\
\hline$\%$ dijakov & 84,0 & 57,0 & 55,0 & 74,0 & 74,0 \\
\hline \multicolumn{6}{|c|}{ Povprečje OECD } \\
\hline$\%$ dijakov & 85,0 & 66,0 & 67,0 & 79,0 & 79,0 \\
\hline \multicolumn{6}{|l|}{ Slovenija } \\
\hline \% dijakov & 80,0 & 30,0 & 56,0 & 74,0 & 74,0 \\
\hline
\end{tabular}

Številke I-5 označujejo zaporedne številke trditev, ki so prikazane v besedilu pred tabelo.

Indeks zaznanega pozitivnega odnosa učiteljev do učenca se je v raziskavi PISA 2009 pokazal kot najvišji v Turčiji, Kanadi, Združenih državah Amerike in na Portugalskem, med državami, kjer je indeks med najnižjimi, pa je poleg Japonske, Koreje in Poljske tudi Slovenija $(-0,42)$. Dijaki na Finskem in Norveškem poročajo o pozitivnejšem zaznanem odnosu učitelja do njih, a v primerjavi s povprečjem držav OECD še vedno pod povprečjem (Finska - -0,16; Norveška - -0,17). Skladno s tem so tudi odstotki po posameznih zgoraj opisanih postavkah na Finskem in Norveškem višji kot v Sloveniji. 30 \% slovenskih dijakov meni, da večino učiteljev zanima, ali se dobro počutijo, kar je $36 \%$ manj, kot se je to izkazalo v povprečju na ravni držav OECD, in $27 \%$ ter $19 \%$ manj, kot so o tem poročali finski in norveški dijaki. Kljub temu pa jih kar $80 \%$ meni, da se dobro razumejo z večino učiteljev, kar pa je še vedno manj od njihovih vrstnikov v mednarodnem povprečju $(85 \%)$ in tudi na Finskem $(87 \%)$ in Norveškem ( 84 \%). 74 \% jih tudi meni, da jim učitelji pomagajo, če potrebujejo dodatno pomoč, in jih obravnavajo pravično. $\mathrm{Na}$ povprečni ravni držav OECD ter na Finskem je bil tak odstotek dijakov višjii(79 \% in 80\%), na Norveškem pa enak kot v Sloveniji. Tudi pri odgovoru na vprašanje, ali večina učiteljev posluša, kaj jim ima dijak za povedati, je bil odstotek slovenskih dijakov, ki se s tem strinja ali popolnoma strinja, i I \% pod povprečjem držav OECD (67\%) ter $7 \%$ pod rezultatom za Finsko in I \% pod rezultatom za Norveško.

$\mathrm{Na}$ ravni držav OECD lahko z indeksom zaznanega pozitivnega odnosa učiteljev do učenca pojasnimo 2,2 \% variabilnosti v bralnih dosežkih. Na Finskem in Norveškem sta odstotka pojasnjene variance višja (Finska 4,I \% in Norveška 7,4 \%), v Sloveniji pa je ome- 
njeni delež precej nižji (o,4 \%) kot v omenjenih državah. V vseh treh državah dijaki, ki poročajo o pozitivnejšem zaznanem učiteljevem odnosu, v povprečju dosegajo višje dosežke na testu bralne pismenosti, vendar prihaja tukaj do določenih razlik med državami. $\mathrm{Na}$ Finskem in Norveškem v povprečju dijaki, ki se uvrščajo v najvišjo četrtino indeksa zaznanega pozitivnega odnosa učitelja, dosegajo tudi najvišje dosežke na testu bralne pismenosti. Bralni dosežki z vrednostmi indeksa naraščajo. To pa ne velja za Slovenijo. Dijake, ki so na testu branja v povprečju dosegali najvišje rezultate (490 in 492 točk), najdemo tudi v drugi in tretji četrtini indeksa (razlike v bralnih dosežkih dijakov so v zgornjih treh četrtinah indeksa minimalne: 489,490 in 492 točk), kjer se njegove vrednosti gibljejo med -0,73 in -0,22. Eno enoto višje vrednosti indeksa v povprečju držav OECD predstavljajo I2,2 točk več na testu bralne pismenosti, v Sloveniji 6,5 točk, na Finskem 20, I točk ter Norveškem kar 23,9 točk.

Slovenski dijaki v povprečju zaznavajo manj pozitiven odnos učiteljev do njih, kot je bilo to ugotovljeno na Finskem in Norveškem, čeprav so bili tudi rezultati za Norveško v nasprotju s Finsko na tem področju podpovprečni. V nasprotju s Finsko in Norveško v Sloveniji vrednost indeksa z višjimi bralnimi dosežki ne narašča. Dijaki, ki so na testu bralne pismenosti v povprečju dosegali višje rezultate, različno ocenjujejo učiteljev odnos do njih; tako pozitivno (vrednosti indeksa $0,7 \mathrm{I}$ ), kot tudi negativno (vrednosti indeksa -0,73). V splošnem lahko rečemo, da se je zaznani pozitiven odnos učitelja do dijakov pokazal kot pomemben dejavnik pri pojasnjevanju dosežkov na testu bralne pismenosti, predvsem na Finskem in Norveškem.

\section{Bralni dosežki glede na indeks socialno-ekonomskega položaja družine}

Odnos med učnimi dosežki in socialnoekonomskim položajem družine, iz katere izhaja učenec, nam pomaga bolje osvetliti pogoje, ki jih različnim učencem zagotavlja nek šolski sistem. Kot eden od indikatorjev stopnje enakosti pogojev v raziskavi PISA nastopa t. i. Indeks ekonomskega, socialnega in kulturnega položaja (ESCS). Omenjeni indeks je sestavljen iz naslednjih dejavnikov: najvišji poklicni položaj staršev, najvišja izobrazbena stopnja staršev (v letih izobraževanja), materialne dobrine doma, kulturne dobrine doma ter izobraževalne dobrine doma. Indeks ekonomskega, socialnega in kulturnega položaja je standardizirana vrednost s povprečjem o in standardnim odklonom I. Tako v Sloveniji kot na Finskem in Norveškem so vrednosti omenjenega indeksa nadpovprečne. Med omenjenimi državami je najvišji indeks ESCS zabeležila Norveška $(0,47)$, sledi ji Finska $(0,37)$, najnižji izmed treh držav pa je zabeležila Slovenija $(0,07)$. 
Na podlagi socialno-ekonomskega položaja družine lahko v Sloveniji pojasnimo I 4,3 \% variabilnosti v bralnih dosežkih, kar je rahlo nad povprečjem držav OECD (I4 \%). Na Finskem in Norveškem sta odstotka nižja, in sicer 7,8 \% (Finska) in 8,6 \% (Norveška). Eno enoto višje vrednosti indeksa se v Sloveniji povezujejo z 39 točkami več na testu bralne pismenosti, kar je nad povprečjem držav OECD ( 38 točk). Na Finskem ta sprememba predstavlja 3 I točk, na Norveškem pa 36 točk. V vseh treh državah pa z vrednostmi indeksa naraščajo tudi bralni dosežki. Tako se v najnižjo četrtino indeksa povsod uvrščajo dijaki z najnižjimi dosežki na testu bralne pismenosti in v najvišjo četrtino tisti z najvišjimi dosežki (444 proti 532 točk v Sloveniji; 504 proti 565 točk na Finskem; 468 proti 536 točk na Norveškem).

Finska in Norveška sta tudi v skupini držav, kjer je bil ugotovljen nadpovprečen socialno-ekonomski status vključenih dijakov, v povprečju pa se državi uvrščata tudi med države z zelo visokimi oz. nadpovprečnimi dosežki. V Sloveniji je slika nekoliko drugačna, in sicer smo v povprečju zabeležili nadpovprečen socialno-ekonomski status sodelujočih dijakov in podpovprečne dosežke na lestvici bralne pismenosti. Morda je zanimiv tudi podatek, da so v državah na Kitajskem (Hong Kong, Singapur), v Južni Koreji in na Japonskem, kjer se na lestvici dosežkov uvrščajo v sam vrh, zabeležili podpovprečen socialno-ekonomski status njihovih dijakov. Nekateri strokovnjaki (Markus v OECD, 20ı ob) menijo, da naj bi večji učinek kot socialno-ekonomsko ozadje dijaka na bralne dosežke imel sam izobraževalni sistem ter način poučevanja.

Slovenija se tudi uvršča med države, ki so v raziskavi PISA 2009 zabeležile nadpovprečen učinek socialno-ekonomskega ozadja dijaka na bralne dosežke, ki se na lestvici uvrščajo pod povprečje. Finska in Norveška pa obratno poročata o podpovprečnem učinku socialno-ekonomskega ozadja na bralne dosežke, ki se na lestvici uvrščajo nad povprečje oz. v primeru Finske v sam vrh (OECD, 2orob).

Torej, tako Slovenija kot Finska in Norveška se uvršcajo med države, kjer je bil v povprečju zabeležen nadpovprečen socialno-ekonomski status sodelujocih dijakov oz. njihovih družin. Prav tako se je ESCS v vseh treh primerjanih državah pokazal kot pomemben dejavnik pri pojasnjevanju dosežkov na testu bralne pismenosti v raziskavi PISA 20og, le da je njegov učinek na dosežke dijakov v Sloveniji, v primerjavi s Finsko in Norveško, večji. Finska in Norveška se v nasprotju s Slovenijo uvrščata med države, kjer so zabeležili podpovprečne učinke socialno-ekonomskega statusa na bralne dosežke, čemur labko botruje tudi sama politika omenjenih držav, kjer je ena izmed najpomembnejših prioritet izobraževalnega sistema ravno zmanjševanje socialnih razlik med učenci. 


\section{Učni dejauniki bralnih dosežkov glede na spol}

$\mathrm{Na}$ ravni vseh držav OECD, vključno s Slovenijo, Finsko in Norveško, so se dekleta na testu bralne pismenosti v povprečju odrezala bolje od fantov. V Sloveniji in na Finskem so dijaki v povprečju dosegli 55 točk manj od deklet (456 proti 5 I I točk v Sloveniji in 508 proti 563 točk na Finskem), na Norveškem pa 47 točk manj (480 proti 527 točk).

Povprečna razlika med spoloma je v državah OECD 39 točk, v EU pa 42 točk (Pedagoški inštitut, 2010). Razlika med spoloma v bralnih dosežkih je tako v vseh treh primerjanih državah večja kot v povprečju držav OECD in EU.

Podobne razlike med spoloma je v vseh treh državah opaziti tudi na področju bralnih navad. V Sloveniji, na Finskem in Norveškem za zabavo bere več dijakinj (75 \% v Sloveniji, 80,6 \% na Finskem in 70 \% na Norveškem) kot dijakov (46 \% v Sloveniji, 53,3 \% na Finskem in 50,4 \% na Norveškem), v branju pa tudi bolj uživajo. Podobne razlike med spoloma se v vseh treh državah pojavljajo tudi pri izbiri vrste bralnega gradiva, in sicer dekleta v vseh treh državah v povprečji večkrat posegajo po leposlovju v kombinaciji z drugim gradivom, medtem ko fantje raje posegajo po časopisih in stripih.

Tudi pri aktivnostih branja na spletu je v vseh treh državah opaziti podobne rezultate. Tako v Sloveniji kot na Finskem in Norveškem so v povprečju na spletu aktivnejši fantje, vendar so razlike minimalne. Prav tako je opaziti, da v vseh treh državah dekleta v večji meri uporabljajo splet kot komunikacijsko sredstvo (branje e-pošte, uporaba klepetalnic), fantje pa uporabljajo splet za iskanje informacij in branje novic. Le na Norveškem so razlike pri uporabi spleta za iskanje informacij in branje novic med fanti in dekleti zelo majhne.

Tudi pri poznavanju in uporabi učinkovitih metakognitivnih in učnih strategij so $\mathrm{v}$ vseh treh državah dekleta v ospredju. Dekleta imajo višje ravni zavedanja uporabnosti strategij za razumevanje in zapomnitev informacij ter poročajo o nekoliko večji meri uporabe učnih strategij, kot sta memoriranje (tukaj je izjema Norveška, kjer dekleta in fantje le-te uporabljajo v enaki meri) in kontrolne strategije. V povprečju držav OECD bi bila razlika v bralnih dosežkih med spoloma za 23 točk nižja, če bi fantje v enaki meri uživali v branju kot dekleta. Is točk več bi fantje dosegali, če bi imeli enako raven zavedanja uporabnosti učinkovitih strategij povzemanja besedila kot dekleta.

Č povzamemo: $v$ Sloveniji, na Finskem in Norveškem so se dekleta na testu bralne pismenosti v povprečju odrezala bolje od fantov. K tovrstnemu rezultatu so v vseh treh državah najverjetneje pripomogli večje zanimanje deklet za branje in uživanje v njem ter poznavanje in zavedanje uporabnosti ućinkovitih metakognitivnih in učnih strategij. 
Rezultati raziskave PISA 2009 pa nam kažejo tudi, da se fantje v vseh državah radi (če ne celo raje) angažirajo pri branju specifičnih bralnih gradiv, prav tako pa veliko berejo tudi na spletu. S tega vidika bi bilo morda dobro v šolah omogočati udejstvovanje dijakov v različnih (ne le tradicionalnih) bralnih aktivnostih. Fante bodo verjetno v večji meri motivirale naloge, ki bodo zahtevale iskanje informacij in podatkov po svetovnem spletu, prav tako pa se bodo bolj angažirali pri branju, kadar za neko področje izkazujejo notranje zanimanje.

\section{Bralni profili slovenskih dijakov}

\section{Bralni dosežki po profilih}

Opis uporabljenih indeksov

Za vsako raven bralne pismenosti smo pregledali, kakšna je povprečna vrednost različnih indeksov, kot so bili izračunani v mednarodnem centru raziskave PISA. Pregledali smo vrednosti naslednjih indeksov:

Socialno-ekonomski status dijaka. Indeks ESCS predstavlja ekonomski, socialni in kulturni položaj dijaka. Sestavljen je iz naslednjih indeksov: najvišji poklicni položaj staršev, najvišja izobrazbena stopnja staršev (v letih izobraževanja), materialne dobrine doma, kulturne dobrine doma ter izobraževalne dobrine doma.

Indeks uživanja v branju (JOYREAD). Indeks je narejen na osnovi odgovorov dijakov na ocenjevalni lestvici, ki vključuje različne trditve o dijakovem branju. Višji indeks pomeni, da dijak bolj uživa v branju in ima pozitivnejši odnos do branja.

Branje za zabavo (ST22 2 Qo $)$. Dijaki so na vprašanje, koliko časa na dan berejo za zabavo, lahko odgovorili s pomočjo naslednje lestvice: $\mathrm{I}=$ ne berem za zabavo, $2=30$ minut ali manj na dan, $3=$ več kot 30 minut in manj kot 60 minut na dan, $4=$ od $\mathrm{I}$ do 2 uri na dan, $5=$ več kot 2 uri na dan. $V$ analizah smo to spremenljivko obravnavali kot intervalno.

Indeks različnosti bralnega gradiva (DIVREAD). Dijak navede, kako pogosto bere različne vrste gradiva (revije, stripe, leposlovje, neleposlovne knjige, časopise) zato, ker to želi (nikoli ali skoraj nikoli, nekajkrat na leto, približno enkrat na mesec, večkrat na mesec, večkrat na teden). Višja vrednost indeksa pomeni branje raznovrstnejšega gradiva.

Indeks dejavnosti branja na spletu (ONLNREAD). Dijak oceni, kako pogosto ( $\mathrm{I}=$ ne poznam, 2 = nikoli, 5 = večkrat na dan) se ukvarja $\mathrm{z}$ aktivnostmi na svetovnem spletu (z branjem elektronske pošte, sodelovanjem v spletni klepetalnici, branjem spletnih novic, uporabo spletnega slovarja ali enciklopedije, iskanjem spletnih informacij o določenih vsebinah, sodelovanjem v skupinski razpravah ali forumih na spletu, iskanjem uporabnih 
informacij na spletu, npr. receptov, urnikov). Višji indeks pomeni večjo stopnjo ukvarjanja s spletnimi dejavnostmi.

Indeks strategij za razumevanje in pomnjenje besedila (UNDREM). Dijak na 6-stopenjski lestvici ( $\mathrm{I}=$ sploh ni uporabna, $6=$ zelo je uporabna) ocenjuje uporabnost različnih strategij branja in razumevanja besedil (A - se osredotoči na dele besedila, ki jih z lahkoto razume; $\mathrm{B}$ - dvakrat hitro prebere besedilo; $\mathrm{C}$ - o vsebini se pogovarja z drugimi; $\mathrm{D}$ - podčrta pomembne dele; $\mathrm{E}$ - povzame besedilo s svojimi besedami; F - besedilo na glas prebere nekomu drugemu). Strategije C, D in E so boljše od strategij A, B in F. Dijaki z višjim indeksom zaznavajo boljše strategije za razumevanje in pomnjenje besedil kot uporabnejše od dijakov z nižjim indeksom.

Indeks strategij povzemanja besedila (METASUM). Dijak na 6-stopenjski lestvici ( $\mathrm{I}=$ sploh ni uporabna, 6 = zelo je uporabna) ocenjuje uporabnost različnih strategij povzemanja besedil (A - napiše povzetek, vanj vključi vse odstavke; B - prepiše stavke dobesedno; $\mathrm{C}$ - preden napiše povzetek, večkrat prebere besedilo, D - preveri, ali so v povzetku predstavljena ključna dejstva; E - prebere besedilo, podčrta pomembnejše stavke, jih napiše s svojimi besedami). Pri računanju indeksa se upošteva, da sta strategiji D in E boljši od strategij $\mathrm{A}$ in $\mathrm{C}$ in ti boljši od strategije $\mathrm{B}$. Dijaki z višjim indeksom zaznavajo boljše strategije za povzemanje besedil kot uporabnejše od dijakov z nižjim indeksom.

Pogostost obiskovanja knjižnice (LIBUSE). Dijak na s-stopenjski lestvici ( $1=$ nikoli, 5 = večkrat na teden) oceni, kako pogosto obišče knjižnico iz različnih razlogov (za izposojo knjig za razvedrilo; za šolsko delo; da tam naredi domačo nalogo; da bere revije ali časopise; da bere knjige za zabavo; da se uči o stvareh, ki niso povezane s poukom; da uporablja internet). Višji indeks pomeni pogostejše obiskovanje knjižnice.

Pogostost uporabe računalnika $v$ šoli (USESCH). Dijak na 4-stopenjski lestvici ( $\mathrm{I}=$ nikoli ali skoraj nikoli, 4 = vsak dan ali skoraj vsak dan) ocenjuje, kako pogosto v šoli uporablja računalnik za različne namene (klepeta prek spleta; uporablja elektronsko pošto; išče informacije za šolsko delo; pobira oz. nalaga gradiva s spletne strani šole ali brska po njej; svoje delo objavlja na spletni strani šole; uporablja računalniške simulacije; vadi in se izpopolnjuje v različnih predmetih; na računalniku samostojno dela domačo nalogo; uporablja ga za skupinsko delo in stike z drugimi dijaki). Višji indeks pomeni več rabe računalnika v šoli.

Pogostost uporabe računalnika doma za šolsko delo (HOMSCH). Dijak na 4-stopenjski lestvici ( $\mathrm{I}=$ nikoli ali skoraj nikoli, $4=$ vsak dan ali skoraj vsak dan) ocenjuje, kako pogosto doma uporablja računalnik v zvezi s šolo (na internetu išče informacije za šolsko delo; 
uporablja elektronsko pošto za dopisovanje z drugimi dijaki o šolskem delu; uporablja elektronsko pošto za stike s profesorji in oddajanje domačih nalog; pobira ali nalaga gradiva s spletne strani šole; na spletni strani pregleda šolska obvestila). Višji indeks pomeni več domače rabe računalnika za šolo.

Indeks interpretacije literarnih tekstov (RFSINTRP) je indeks bralnih dejavnosti, ki jih dijak izvaja v učne namene. Dijak označi, kako pogosto je v zadnjem mesecu bral literarna dela, razlagal vzroke dogodkov v besedilu, način obnašanja oseb v besedilu in namen besedila. Višji indeks pomeni več bralnih dejavnostiv učne namene.

Indeks zaznane uciteljeve spodbude pri bralnih aktivnostib (STIMREAD). Dijak na 4-stopenjski lestvici ( $\mathrm{I}=$ nikoli ali zelo redko, $4=$ pri vseh urah) odgovarja na postavke, ki sprašujejo, kako pogosto učitelj pri pouku slovenščine spodbuja dijake (zahteva, da pojasnijo pomen besedila; $\mathrm{z}$ vprašanji spodbuja $\mathrm{k}$ boljšemu razumevanju besedila; jim da dovolj časa, da razmislijo; priporoči v branje kakšno knjigo; jih spodbuja, da izrazijo svoje mnenje o besedilu; jim pomaga povezati brane zgodbe z njihovim življenjem; pokaže, kako informacije iz besedil nadgrajujejo njihovo predhodno znanje). Višji indeks pomeni večjo spodbudo pri bralnih aktivnostih s strani učitelja.

Vzorec

Skupno obteženo število dijakov (tj. število dijakov v populaciji, ki so jih predstavljali dijaki v vzorcu) je bilo: I.I58 na ravni ib (334 točk ali manj pri verjetni oceni bralnega dosežka PVIREAD), 2.787 na ravni ia (335 do 406 točk), 4.753 na ravni 2 (407 do 479 točk), 5.416 na ravni 3 (480 do 552 točk), 3.63 I na ravni 4 ( 553 do 625 točk), 788 na ravni 5 (626 do 697 točk) in 52 na ravni 6 (več kot 698 točk). Pri posameznih spremenljivkah je bilo nekaj manjkajočih podatkov (na ravni Ib največ 306 , na ravni Ia največ 407, na ravni 2 največ 325 , na ravni 3 največ 238 , na ravni 4 največ 160 , na ravni 5 največ 32 in na ravni 6 največ 8).

Postopek obdelave podatkov

Podatke smo obtežili z utežjo W_FSTUWT (utežjo, ki jo izračunajo za vsakega dijaka v mednarodnem centru raziskave PISA glede na značilnosti vzorčenja dijakov) in vse spremenljivke (WLE indekse) pretvorili v standardizirane vrednosti, da bi bile razlike (in velikost razlik) med posameznimi ravnmi bralne pismenosti primerljive. Izračunali smo povprečno $z$-vrednost različnih spremenljivk za slovenske dijake s posamezno ravnjo dosežkov. Povprečna $z$-vrednost pri posamezni spremenljivki pove, za koliko standardnih deviacij populacije se povprečje, značilno za dijake posamezne ravni dosežkov, razlikuje od povprečne vrednosti spremenljivke v Sloveniji. 


\section{Rezultati}

\begin{tabular}{|c|c|c|c|c|c|c|c|c|c|c|c|c|c|c|c|c|c|}
\hline \multirow{2}{*}{ 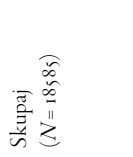 } & $x^{\circ}$ & & \begin{tabular}{c}
$\infty$ \\
$\vdots$ \\
\hdashline
\end{tabular} & 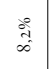 & $\mid \begin{array}{c}\stackrel{8}{1} \\
\infty \\
\infty\end{array}$ & \begin{tabular}{l}
$\infty$ \\
$\infty$ \\
\hdashline
\end{tabular} & 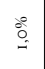 & $\stackrel{8}{*}$ & $x^{\circ}$ & 荑 & 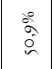 & $\therefore$ & 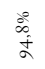 & 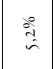 & $\frac{\bar{\sigma}}{2}$ & 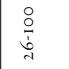 & $i_{i}^{0}$ \\
\hline & $\gamma$ & & $\begin{array}{l}7 \\
0 \\
0 \\
0\end{array}$ & $\stackrel{\infty}{\Xi}$ & $\begin{array}{l}\infty \\
0 \\
0 \\
1 \\
1\end{array}$ & $\overbrace{\substack{4 \\
0}}^{0}$ & $\stackrel{ \pm}{ \pm}$ & $\begin{array}{c}\infty \\
\vdots \\
\sim\end{array}$ & - & $\frac{\jmath}{\alpha}$ & 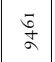 & - & $\tilde{\underline{n}}$ & \& & $=$ & 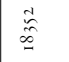 & $\begin{array}{l}\qquad \\
\infty \\
\infty \\
\infty\end{array}$ \\
\hline \multirow{2}{*}{ 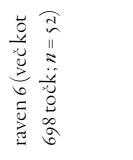 } & $\therefore$ & & $\begin{array}{l}\stackrel{8}{0} \\
0 \\
0 \\
0\end{array}$ & $\vdots_{0}^{\circ}$ & $\begin{array}{l}0 \\
0 \\
0 \\
0\end{array}$ & $\begin{array}{l}\circ \\
0 \\
0\end{array}$ & $\begin{array}{l}0_{0}^{\circ} \\
0\end{array}$ & $\begin{array}{l}\vdots \\
\vdots \\
0 \\
0\end{array}$ & $\therefore$ & 势 & 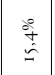 & $2^{\circ}$ & $\begin{array}{l}\stackrel{8}{\circ} \\
0 \\
0 \\
0\end{array}$ & $\begin{array}{l}\vdots \\
\vdots \\
0 \\
0\end{array}$ & $\frac{\bar{\sigma}}{\bar{n}}$ & 㝘品 & : \\
\hline & - & & $\therefore$ & $\circ$ & $\circ$ & $\circ$ & $\circ$ & $\circ$ & -2 & $\neq$ & $\infty$ & - & $\therefore$ & $\circ$ & $=$ & $\approx$ & $\therefore$ \\
\hline \multirow{2}{*}{ 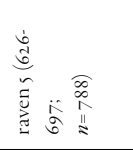 } & $\therefore$ & & \begin{tabular}{l}
$\stackrel{\circ}{7}$ \\
\multirow{2}{\alpha}{}
\end{tabular} & 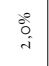 & $\infty$ & :̊ํㅇ & $\begin{array}{l}\vdots \\
\vdots \\
0\end{array}$ & $\begin{array}{l}\vdots \\
\vdots \\
0 \\
0\end{array}$ & $\therefore$ & 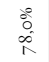 & 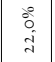 & $\partial^{\circ}$ & 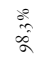 & $\stackrel{\circ}{\stackrel{\circ}{1}}$ & $\frac{\bar{\sigma}}{\Sigma}$ & $\stackrel{2}{\circ} \stackrel{8}{\circ}$ & $\begin{array}{l}0 \\
\vdots \\
0\end{array}$ \\
\hline & - & & 吉 & $\cong$ & $\stackrel{i}{i n}$ & $\circ$ & $\circ$ & $\circ$ & 7 & $\stackrel{5}{6}$ & $E$ & - & $\check{\circ}$ & $=$ & $=$ & $\begin{array}{l}\infty \\
\wedge\end{array}$ & $\stackrel{\substack{\infty \\
\gtrless}}{R}$ \\
\hline \multirow{2}{*}{ 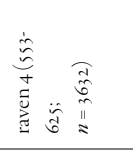 } & $\therefore$ & & 帝 & 然 & $\stackrel{\mathscr{\infty}}{\stackrel{\infty}{=}}$ & 离 & $\stackrel{8}{\circ}$ & $\begin{array}{l}: \\
0 \\
0\end{array}$ & $x^{\circ}$ & 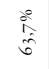 & 角 & $\therefore$ & 资 & $\frac{\stackrel{\circ}{i}}{i}$ & $\frac{\bar{\sigma}}{\bar{v}}$ & $\stackrel{亡}{\partial} \stackrel{8}{\circ}$ & $i$ \\
\hline & $>$ & & 㐫 & $\alpha$ & $\begin{array}{l}\infty \\
7 \\
7\end{array}$ & 6 & $\circ$ & $\circ$ & 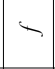 & $\stackrel{ \pm}{\vec{\lambda}}$ & $\triangleq$ & - & 卓 & I & $=$ & 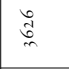 & 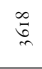 \\
\hline \multirow{2}{*}{ 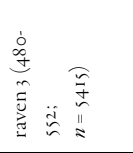 } & $\therefore$ & & 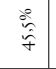 & 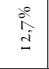 & 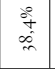 & 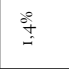 & $\begin{array}{l}\overbrace{0}^{\circ} \\
0 \\
0\end{array}$ & $\stackrel{2}{2}$ & $\therefore$ & 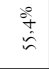 & $\begin{array}{l}\stackrel{8}{8} \\
\dot{+}\end{array}$ & $\dot{x}^{\circ}$ & 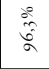 & $\stackrel{8}{i}$ & $\frac{\bar{\sigma}}{2}$ & 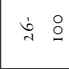 & iv \\
\hline & - & & $\begin{array}{l}0 \\
\vdots \\
\vdots \\
d\end{array}$ & 8 & 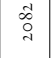 & $\stackrel{\infty}{\wedge}$ & - & $\stackrel{\mathrm{g}}{-}$ & - & $\stackrel{\vec{o}}{\circ}$ & $\underset{q}{q}$ & - & $\stackrel{\infty}{+\infty}$ & $\stackrel{\circ}{\circ}$ & $=$ & $\begin{array}{l}+ \\
\stackrel{+}{n}\end{array}$ & $\tilde{n}$ \\
\hline \multirow{2}{*}{ 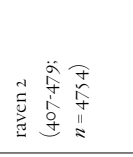 } & $\therefore$ & & $\begin{array}{l}\stackrel{\circ}{\circ} \\
=\end{array}$ & 总 & 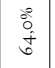 & 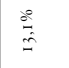 & 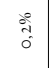 & $\begin{array}{l}\stackrel{8}{8} \\
+ \\
+\end{array}$ & $\therefore$ & 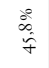 & $\begin{array}{l}\text { ‡े } \\
\pm \\
\pm\end{array}$ & $\therefore$ & $\frac{8}{\alpha^{2}}$ & $\begin{array}{l}8 \\
0 \\
0 \\
0\end{array}$ & $\frac{5}{2}$ & $\dot{\mathrm{d}}$ & iv \\
\hline & $\gamma$ & & $\hat{\imath}$ & $\stackrel{6}{\circ}$ & \begin{tabular}{c}
7 \\
\multirow{2}{0}{} \\
\hdashline
\end{tabular} & สิ & 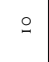 & $\stackrel{\infty}{\stackrel{\infty}{-1}}$ & - & $\frac{\hat{a}}{\mathrm{t}}$ & $\begin{array}{l}0 \\
\vdots \\
a\end{array}$ & - & $\mid \begin{array}{l}q \\
f \\
f\end{array}$ & 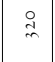 & $=$ & $\frac{\sqrt{2}}{a}$ & 等 \\
\hline \multirow{2}{*}{ 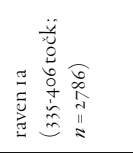 } & $8^{\circ}$ & & $\begin{array}{l}\stackrel{8}{\circ} \\
i\end{array}$ & $\stackrel{\infty}{\infty}$ & 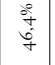 & $\begin{array}{l}\text { s. } \\
\text { so } \\
\text { of }\end{array}$ & 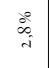 & $\frac{\stackrel{\circ}{\circ}^{\circ}}{\infty}$ & $\therefore$ & 造 & 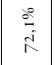 & $\therefore$ & 总 & $\begin{array}{l}\dot{\infty} \\
\dot{\infty} \\
\dot{\infty}\end{array}$ & $\frac{5}{\Sigma}$ & $\stackrel{\tau}{=}$ & $\circ$ \\
\hline & - & & $\therefore$ & $\therefore$ & $\hat{\mathrm{a}}$ & \begin{tabular}{|c} 
od \\
$\stackrel{0}{0}$
\end{tabular} & 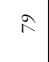 & ส & - & $\vDash$ & $\begin{array}{l}\circ \\
\vdots \\
0\end{array}$ & - & $\mid \begin{array}{l}\infty \\
\vdots \\
d \\
a\end{array}$ & I & $=$ & हे & $\underset{d}{\stackrel{y}{7}}$ \\
\hline \multirow{3}{*}{ 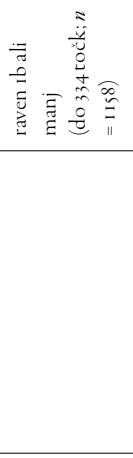 } & $\therefore$ & & 范 & $\stackrel{\circ}{\circ}$ & 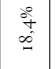 & 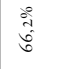 & $\begin{array}{l}0 \\
\vdots \\
\alpha \\
\alpha\end{array}$ & 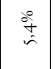 & $\therefore$ & 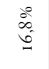 & $\begin{array}{c}\overbrace{}^{\circ} \\
\infty \\
\infty\end{array}$ & $\therefore$ & $\begin{array}{c}x^{8} \\
\text { a. } \\
\infty\end{array}$ & $\stackrel{\stackrel{2}{=}}{=}$ & $\frac{5}{2}$ & $\stackrel{\widetilde{I}}{=}$ & $\circ$ \\
\hline & - & & $\wedge$ & + & $\overrightarrow{\vec{a}}$ & 定 & $\stackrel{+}{\stackrel{+}{-}}$ & $\tilde{6}$ & - & $\cong$ & 旁 & - & $\approx$ & $\triangleq$ & $=$ & $\underset{\underline{\sigma}}{\underline{\underline{\sigma}}}$ & $\stackrel{\circ}{\circ}$ \\
\hline & & & 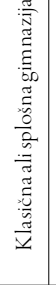 & 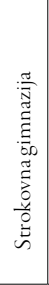 & 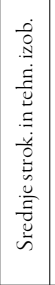 & 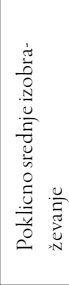 & 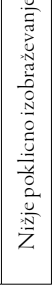 & 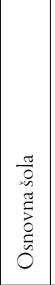 & 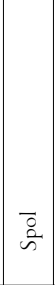 & 吾 & $\begin{array}{l}\frac{\vec{t}}{0} \\
\frac{0}{2}\end{array}$ & 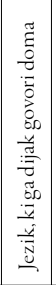 & 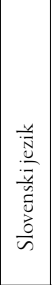 & 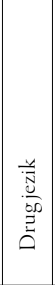 & & 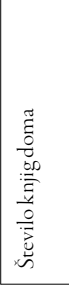 & 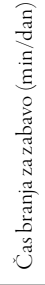 \\
\hline
\end{tabular}

Tabela in: Primerjava pogostosti posameznih kategorij pri dijakih z različnimi ravnmi dosežkov na testu bralne pismenosti pri različnih nominalnih spremenljivkah in median pri ordinalnih spremenljivkah 
Povprečna z-vrednost spremenljivke za posamezno raven dosežkov

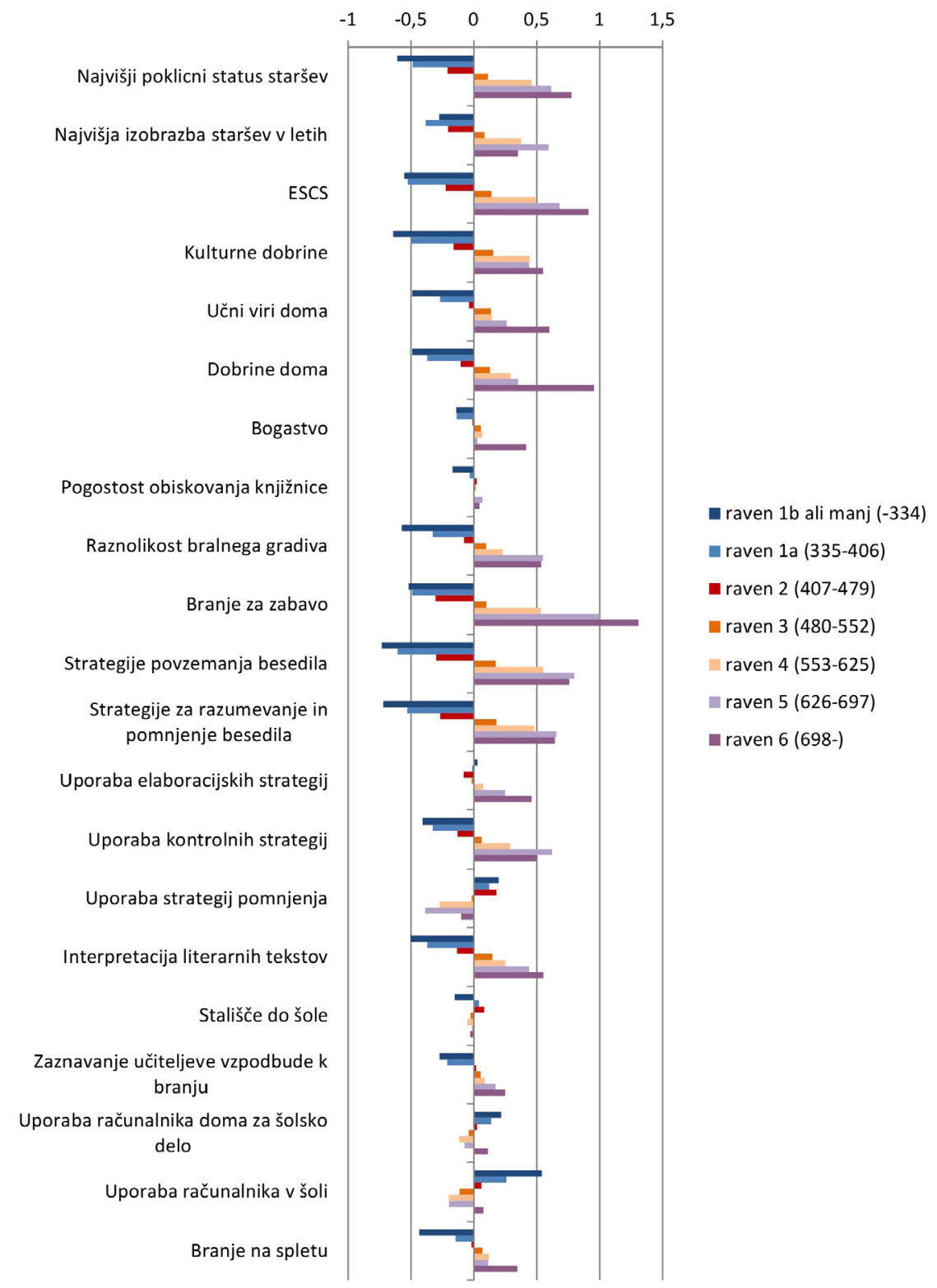

Slika I: Razlike med dijaki z različnimi ravnmi dosežkov po posameznih spremenljivkah. 
V Tabeli I I vidimo, da med dijaki z dosežki na ravni ıb prevladujejo dijaki s poklicnim srednjim izobraževanjem, med dijaki z dosežki na ravni ra dijaki srednjega strokovnega in tehničnega izobraževanja, prav tako med dijaki z dosežki na ravni 2. Pri dijakih z dosežki na ravni 3 ali več pa prevladujejo dijaki klasične ali splošne gimnazije.

VTabeli i je tudi razvidno, da je med dijaki z dosežki na ravni ib visok delež moških. $Z$ višanjem ravni dosežkov se delež moških vse bolj niža, delež žensk pa sorazmerno viša. $\mathrm{Z}$ višanjem ravni dosežkov tudi upada delež dijakov, ki doma ne govorijo slovenskega jezika. Prav tako se z ravnjo dosežkov veča povprečno število knjig, ki jih imajo dijaki doma, in daljša čas branja za zabavo.

Na Sliki i pa lahko ugotovimo, na katerih spremenljivkah se slovenski dijaki z različnimi ravnmi dosežkov najbolj razlikujejo med sabo. Večje razlike so opazne pri spremenljivkah, vezanih na izobrazbo in poklicni status staršev dijaka ter na socialno-ekonomsko-kulturni status družine dijaka. Samo bogastvo nima tolikšnega vpliva na dosežek bralne pismenosti, kot ga ima količina dobrin, kot so kulturne dobrine in učni viri doma.

Dijaki z različnimi ravnmi dosežkov se razlikujejo v raznolikosti bralnega gradiva, branju za zabavo, strategijah povzemanja besedila, strategijah za razumevanje in pomnjenje besedila. Drugod so razlike manjše. Vidne so še pri rabi kontrolnih strategij, negativna je povezava s strategijami pomnjenja. V pogostejši uporabi elaboracijskih strategij izstopajo predvsem dijaki z ravnmi dosežkov $s$ in 6 . Dijaki na višjih ravneh tudi pogosteje interpretirajo literarne tekste. Dijaki z boljšimi dosežki zaznavajo več vzpodbude za branje s strani učitelja.

$\mathrm{V}$ pogostosti obiskovanja knjižnice, uporabi strategij strukturiranja besedila, stališčih do šole, stališčih do računalnikov, dostopnosti računalnikov in njihovi uporabi za šolsko delo ni velikih razlik. Dijaki s slabšimi dosežki pogosteje uporabljajo računalnik v šoli in redkeje berejo na spletu, pogosteje pa internet uporabljajo za zabavo.

\section{Profil slovenskih dijakov na treh ravneh bralne pismenosti z vidika bralnega procesa}

V raziskavi smo želeli tudi ugotoviti, ali se da dijake združiti v skupine po podobnosti glede na to, kakšne lastnosti opredeljujejo njihovo branje, tj. glede na metakognitivne strategije, ki se jih zavedajo in jih uporabljajo, učne strategije, motivacijo za branje, raznolikost bralnega gradiva, branje na spletu in interpretacijo literarnih tekstov. Zanimalo nas je, kakšne skupine dijakov bi nastale, $v$ čem bi se med seboj ločile in kako bi se razlikovale glede na dosežke pri posameznih vidikih bralnega procesa. 
Opis ravni dosežkov z vidika bralnega procesa

V raziskavi PISA 2009 ugotavljajo izraženost bralne pismenosti tudi z vidika treh vrst bralnega procesa:

I. Iskanje in priklic informacij. Gre za prepoznavanje in sposobnost poiskati specifične podatke znotraj besedila.

2. Povzemanje in interpretiranje besedila. Pomeni, da posameznik na podlagi prebranega besedila in pravilnega razumevanja le-tega razvije lastno interpretacijo (razlago) določenega dogajanja v besedilu.

3. Razmišljanje o prebranem in ovrednotenje prebranega. Posameznik se zna opredeliti do določenega problema, ki je v nalogi izpostavljen, izraziti lastno razmišljanje o besedilu ter svoj odgovor povezati in pojasniti s pomočjo interpretacije specifičnih podatkov v besedilu ter primerjanja le-teh.

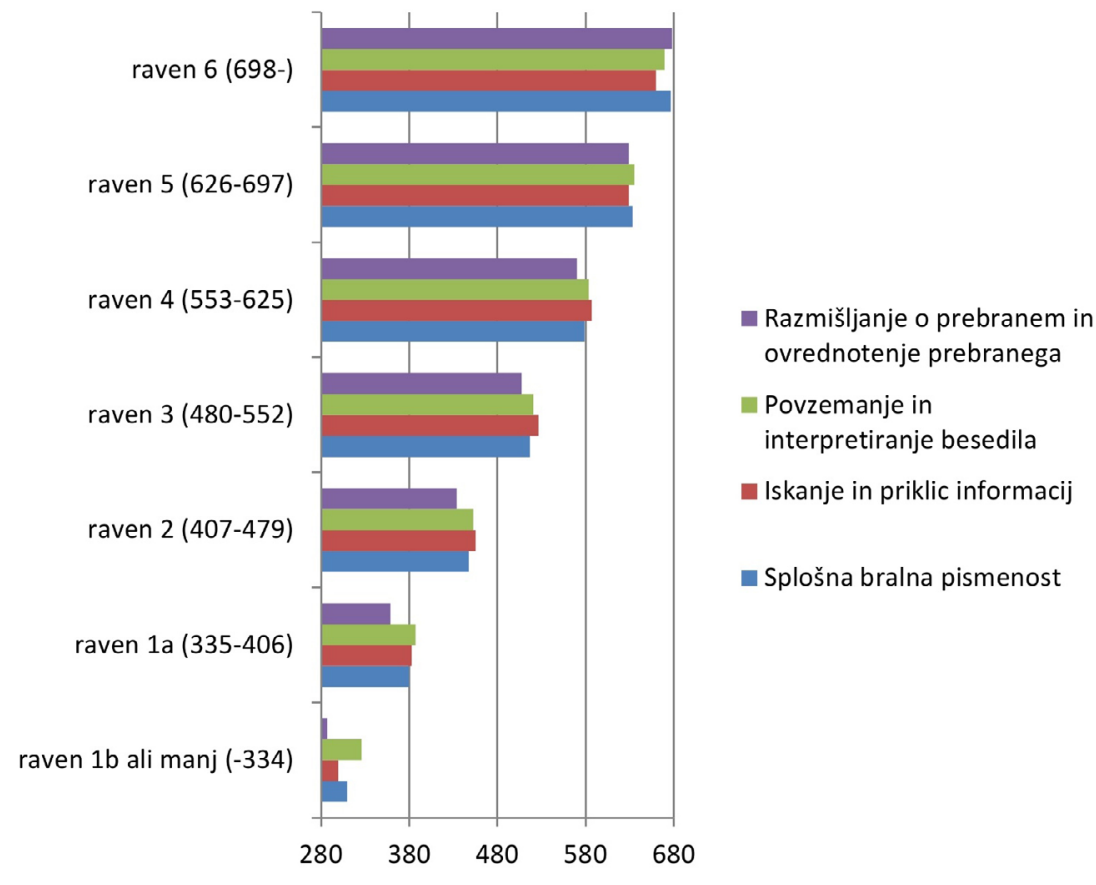

Povprečni dosežek pri posameznem vidiku bralnega procesa

Slika 2: Povprečni splošni dosežek na testu bralne pismenosti in povprečni dosežki pri posameznem vidiku bralnega procesa pri dijakih, uvrščenih na določeno raven bralne pismenosti. 
Dijaki, ki dosegajo posamezne ravni bralne pismenosti (definirane na osnovi skupnega dosežka na testu bralne pismenosti), se seveda razlikujejo tudi po povprečnih dosežkih na posamezni vrsti bralnega procesa. Slika 2 prikazuje, kakšni so bili povprečni dosežki za posamezni vidik bralnega procesa $v$ skupinah dijakov na različnih ravneh bralne pismenosti. Prikazane so povprečne vrednosti verjetnih vrednosti PVIREADI (Iskanje in priklic informacij, prva od petih verjetnih vrednosti), PVIREAD2 (Povzemanje in interpretiranje besedila, prva od petih verjetnih vrednosti) in $\mathrm{PVIREAD}_{3}$ (Razmišljanje o prebranem in ovrednotenje prebranega, prva od petih verjetnih vrednosti). Pri analizi smo združili dijake, ki dosegajo raven $\mathrm{ib}$, z dijaki, ki te ravni ne dosegajo.

Na Sliki 2 vidimo, da je bilo za dijake na vseh ravneh, razen na ravni 6, značilno, da so imeli na področju razmišljanja o prebranem in ovrednotenja prebranega v povprečju nižji dosežek kot na področjih iskanja in priklica informacij ter povzemanja in interpretiranja besedila.

Uporabljeni indeksi

Dijake smo združevali v skupine glede na njihove vrednosti na naslednjih spremenljivkah:

- Metakognitivne strategije: strategije povzemanja besedila, strategije razumevanja in pomnjenja besedila

- Učne strategije: strategije elaboracije, kontrolne strategije, strategije pomnjenja (memoriranja)

- Motivacija (zavzetost) za branje: branje za zabavo, uživanje ob branju

- Raznolikost bralnega gradiva

- Branje na spletu

- Interpretacija literarnih tekstov

Vzorec in obdelava podatkov

Analize smo izvedli na vzorcu 5246 dijakov (obteženi $N=16626$ ), ki so imeli podatke na vseh zgoraj navedenih indeksih. Podatke smo združevali z dvostopenjsko klastrsko analizo, ki je metoda, primerna za obdelavo večjih baz podatkov. Analiza neobtežene podatke preliminarno združi v skupini, izloči izstopajoče podatke in nato ponovno združuje v skupine. Spremenljivke smo v analizo vnesli kot zvezne spremenljivke, ki smo jih predhodno standardizirali. Pregledali smo različne rešitve (od 2 do 6 skupin) in se nazadnje odločili za rešitev s 5 skupinami, ker je bila najbolj interpretabilna. Rešitev je bila na meji sprejemljivosti (mera kohezije in ločenosti skupin je bila cca. O,15). 
Dijake smo tako razdelili v pet skupin. Za vsako skupino smo izračunali povprečne vrednosti (obteženih) standardiziranih indeksov in nato tudi povprečne (obtežene) dosežke pri posameznih vidikih bralnega procesa.

\section{Rezultati}

Z dvostopenjsko klastrsko analizo smo slovenske dijake uvrstili v pet klastrov glede na značilnosti njihove bralne motivacije ter učnih in metakognitivnih strategij pri branju besedil. V prvi skupini je bilo 936 dijakov (obteženi $n=2449$; 14,7 \%), v drugi skupini 891 dijakov (obteženi $n=2432 ;$ I 4,6 \%), v tretji skupini I 504 dijaki (obteženi $n=4764 ; 28,7$ $\%$ ), v četrti skupini 843 dijakov (obteženi $n=33$ I ; 20,0 \%) in v peti skupini I072 dijakov (obteženi $n=3670 ; 22, \mathrm{I} \%$ ).

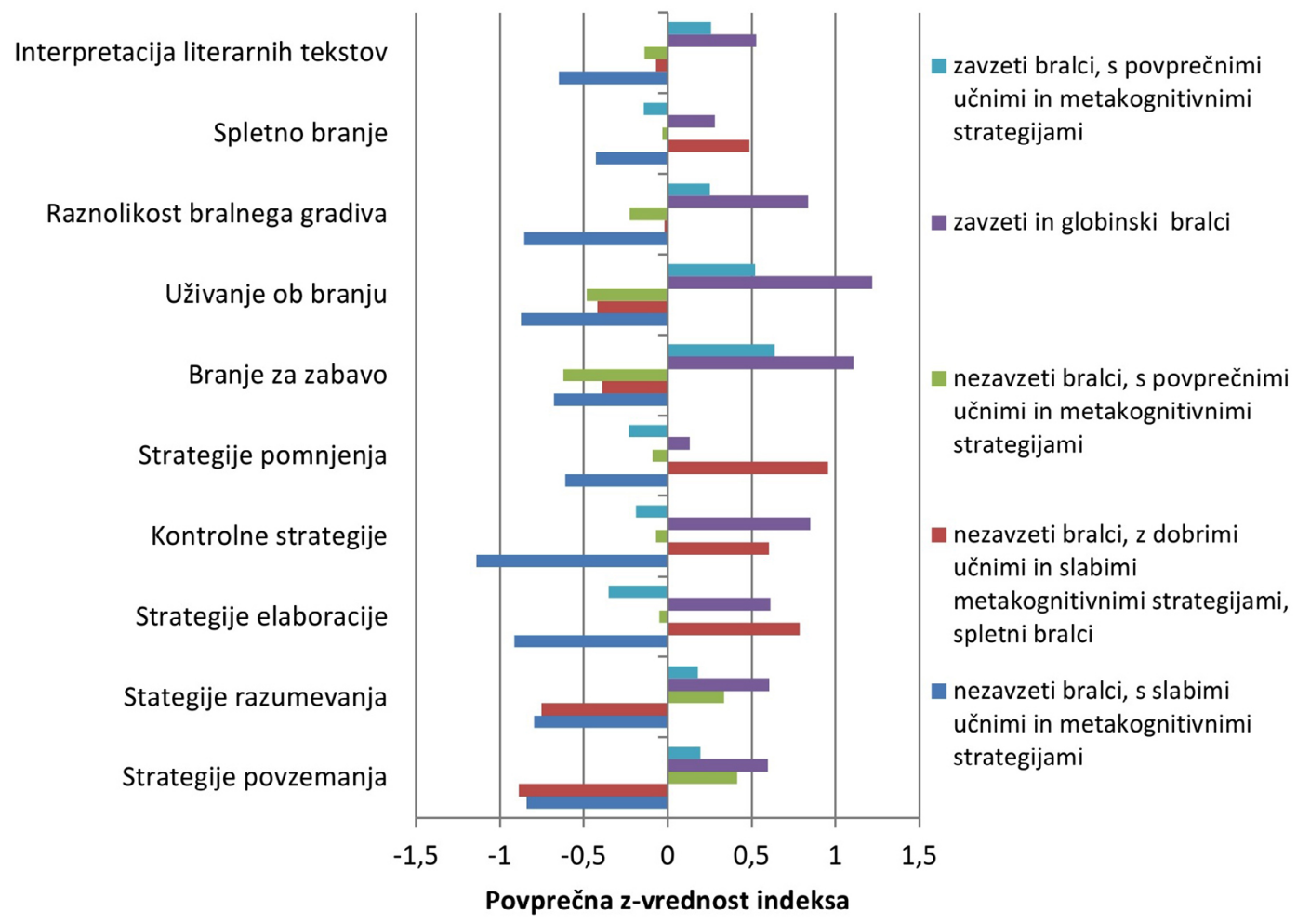

Slika 3: Povprečne standardizirane vrednosti posameznih indeksov v petih skupinah dijakov. 
$\mathrm{Na}$ Sliki 3 so prikazane povprečne vrednosti posameznih indeksov, tj. lastnosti branja, v različnih skupinah dijakov. Slika nam pomaga opisati pet nastalih skupin.

Skupine (klastre) dijakov lahko opišemo na naslednji način:

$\mathrm{V}$ prvem klastru (I4,7 \%) se nahajajo dijaki, ki imajo slabše razvite metakognitivne strategije za razumevanje in pomnjenje besedila ter strategije povzemanja besedila. Prav tako dijaki v tej skupini pri učenju v manjši meri uporabljajo strategije elaboracije in kontrolne strategije. Med učnimi strategijami še najmanj od slovenskega povprečja odstopa prisotnost strategij pomnjenja, vendar je tudi zanje značilna podpovprečna raba. Motivacija (zavzetost) za branje je nizka, v manjši meri je prisotna raznolikost bralnega gradiva ter branje na spletu. Dijaki v omenjeni skupini tudi v manjši meri kot druge skupine berejo literarne tekste in jih poglobljeno obravnavajo. Omenjeno skupino dijakov smo poimenovali Nezavzeti bralci s slabimi učnimi in metakognitivnimi strategijami.

V drugem klastru (I4,6 \%) se nahajajo dijaki, ki imajo (podobno kot dijaki v prvi skupini) slabše od slovenskega povprečja razvite metakognitivne strategije za razumevanje in pomnjenje besedila ter strategije povzemanja besedila. Kljub temu so učne strategije v tej skupini dijakov v primerjavi z drugimi skupinami dobro razvite, med njimi prevladujejo strategije pomnjenja (dijaki si skušajo zapomniti nove informacije, da bi jih kasneje lahko obnovili na glas in se učijo tako, da znova in znova berejo učno besedilo). Vendar je tudi v tej skupini motivacija (zavzetost) za branje nižja od slovenskega povprečja, v povprečju se nahaja ukvarjanje z literarnimi teksti, nekoliko nadpovprečno je prisotno spletno branje. Omenjeno skupino dijakov smo poimenovali Nezavzeti bralci z dobrimi ućnimi in slabimi metakognitivnimi strategijami, spletni bralci.

$\mathrm{V}$ tretjem klastru $(28,7 \%)$ se nahajajo dijaki, ki imajo povprečno razvite metakognitivne in učne strategije (pri metakognitivnih strategijah se nahajajo nekoliko nad slovenskim povprečjem, pri učnih strategijah pa nekoliko pod povprečjem), vendar je motivacija za branje nižja od povprečja, prav tako so dijaki v tej skupini povprečni bralci spletnih strani ter se povprečno ukvarjajo z literarnimi teksti. Omenjeno skupino dijakov smo poimenovali Nezavzeti bralci s povprečnimi učnimi in metakognitivnimi strategijami.

$\mathrm{V}$ četrtem klastru (20,0\%) se nahajajo dijaki, ki imajo v primerjavi z drugimi nadpovprečno razvite metakognitivne strategije povzemanja ter razumevanja in pomnjenja besedila. Pri učenju nadpovprečno uporabljajo tudi elaboracijske in kontrolne strategije, strategije pomnjenja so na povprečni ravni. Nadpovprečno berejo za zabavo in pri branju uživajo, pri tem uporabljajo raznolika bralna gradiva. So povprečni spletni bralci, nekoli- 
ko nad povprečjem se ukvarjajo z interpretacijo literarnih tekstov. To skupino dijakov smo poimenovali Zavzeti in globinski bralci.

$\mathrm{V}$ petem klastru (22,I \%) se nahajajo dijaki, ki imajo povprečno razvite metakognitivne in učne strategije (primerjalno so učne strategije glede na ostale skupine dijakov razvite v manjši meri). To je skupina precej zavzetih bralcev (vendar so primerjalno manj motivirani kot dijaki v četrtem klastru), ki pa so povprečni bralci spletnega gradiva, $\mathrm{v}$ povprečju je tudi njihovo ukvarjanje z interpretacijo literarnih tekstov. To skupino dijakov smo poimenovali Zavzeti bralci, s povprečnimi učnimi in metakognitivnimi strategijami.

Na Sliki 3 lahko ugotovimo, da se skupina zavzetih in globinskih bralcev (skupina 4) od ostalih skupin najbolj razlikuje v zavzetosti za branje ter v raznolikosti gradiva, ki ga berejo (literarni in neliterarni teksti). Skupina, ki ima tudi nadpovprečne vrednosti pri omenjenih spremenljivkah, je skupina zavzetih bralcev, ki imajo povprečno razvite metakognitivne in učne strategije (skupina 5). Skupina zavzetih in globinskih bralcev ima tudi nadpovprečno razvite metakognitivne in učne strategije (čeprav je nadpovprečnost manj izrazita kot pri motivaciji za branje). Med učnimi strategijami prevladujejo kontrolne strategije in strategije elaboracije, ne pa tudi strategije pomnjenja, ki so prisotne na povprečni ravni. Zavzeti in poglobljeni bralci torej pri svojem učenju uporabljajo predvsem učinkovitejše učne strategije, ki jim omogočajo, da prebrano bolje razumejo (in si ne le površinsko zapomnijo), ter jim pomagajo, da si bolje pojasnijo tiste dele besedil, ki jih kljub prebranemu še vedno ne razumejo dobro. Skupina, ki ima podobno visoke vrednosti na indeksih kontrolnih strategij in strategij elaboracije, je skupina nezavzetih (spletnih) bralcev z nadpovprečnimi učnimi in podpovprečnimi metakognitivnimi strategijami (skupina 2). Med skupinami se kot najbolj »ranljiva« kaže skupina nezavzetih bralcev s slabimi učnimi in metakognitivnimi strategijami (skupina I). Označujejo jo podpovprečne vrednosti na vseh vključenih motivacijskih, metakognitivnih in učnih dejavnikih.

Standardizirane vrednosti indeksov nam lahko služijo za primerjavo skupin med seboj in za primerjavo posamezne skupine s slovenskim povprečjem, ki je značilno za posamezen indeks. Surove vrednosti indeksov (tj. vrednosti v nestandardizirani obliki) pa nam pomagajo razumeti, kakšne so povprečne izraženosti posameznih indeksov v primerjavi s povprečjem držav $\operatorname{OECD}(M=0, S D=$ i; razen pri spremenljivki Branje za zabavo, kjer vrednosti na lestvici potekajo od I do 5). Na osnovi vrednosti v Tabeli I 2 lahko zaključimo, da so poimenovanja skupin primerna tudi glede na povprečje držav OECD. Na pri- 
mer, v skupini 5 smo dijake poimenovali kot zavzete bralce, saj so imeli v primerjavi s slovenskim povprečjem nadpovprečna standardizirana indeksa branja za zabavo in uživanja ob branju. Mera uživanja ob branju je, denimo, nadpovprečna (čeprav nekoliko manj izrazito) tudi, če jo v surovi obliki primerjamo s povprečjem držav OECD.

Tabela I2: Povprečne vrednosti indeksov v surovi, nestandardizirani obliki, v različnih skupinah dijakov

\begin{tabular}{|c|c|c|c|c|c|c|c|c|c|c|c|c|}
\hline & \multicolumn{2}{|c|}{ ski } & \multicolumn{2}{|c|}{ sk2 } & \multicolumn{2}{|c|}{$\mathrm{sk}_{3}$} & \multicolumn{2}{|c|}{$\mathrm{sk}_{4}$} & \multicolumn{2}{|c|}{ sks } & \multicolumn{2}{|c|}{ Skup. } \\
\hline Indeks & M & SD & M & SD & M & SD & M & SD & M & SD & M & SD \\
\hline Strategije povzemanja & $-1,06$ & 0,90 & $-1,10$ & $0,8 \mathrm{I}$ & 0,23 & 0,75 & 0,42 & 0,77 & O,OI & 0,90 & $-0,17$ & 1,02 \\
\hline Stategije razumevanja & $-0,87$ & 0,90 & $-0,82$ & 0,90 & 0,27 & 0,77 & 0,54 & 0,80 & 0,11 & 0,88 & $-0,04$ & 1,00 \\
\hline Strategije elaboracije & $-0,68$ & 0,88 & 0,97 & 0,86 & 0,16 & 0,73 & 0,80 & 0,85 & $-0,14$ & 0,74 & $0,2 \mathrm{I}$ & 0,97 \\
\hline Kontrolne strategije & $-0,92$ & 0,85 & 0,72 & 0,86 & 0,09 & 0,64 & 0,95 & 0,75 & $-0,02$ & 0,54 & 0,18 & 0,93 \\
\hline Strategije pomnjenja & $-0,5 \mathrm{I}$ & 0,89 & 0,95 & 0,85 & $-0,02$ & 0,74 & 0,19 & 0,94 & $-0,15$ & 0,70 & 0,06 & 0,92 \\
\hline Branje za zabavo & 1,28 & 0,54 & 1,58 & 0,68 & 1,34 & 0,48 & 3,13 & 0,97 & 2,64 & $0,8 \mathrm{I}$ & $2, \mathrm{OI}$ & $\mathrm{I}, \mathrm{O} 4$ \\
\hline Uživanje ob branju & $-1,04$ & 0,75 & $-0,60$ & 0,67 & $-0,66$ & 0,59 & 0,97 & 0,73 & 0,30 & 0,54 & $-0,17$ & 0,97 \\
\hline Raznolikost bralnega gradiva & $-0,70$ & 0,97 & 0,02 & 0,72 & $-0,16$ & 0,54 & 0,75 & 0,78 & 0,25 & 0,55 & 0,06 & 0,83 \\
\hline Spletno branje & $-0,15$ & $\mathrm{I}, \mathrm{O} 7$ & 0,74 & 1,19 & 0,23 & 0,73 & 0,54 & 0,91 & 0,13 & 0,75 & 0,29 & 0,95 \\
\hline $\begin{array}{l}\text { Interpretacija literarnih te- } \\
\text { kstov }\end{array}$ & $-0,69$ & 0,98 & $-0,14$ & 0,91 & $-0,2 \mathrm{I}$ & 0,76 & 0,42 & 0,86 & 0,17 & 0,90 & $-0,06$ & 0,94 \\
\hline
\end{tabular}

Opombe: SkI pomeni skupino I (obteženi $n=2449)$, sk2 skupino 2 (obteženi $n=2432)$, skz skupino 3 (obteženi $n=4764$ ), sk4 skupino 4 (obteženi $n=331 \mathrm{I})$, sks skupino 5 (obteženi $n=3670$ ), Skup. pa vse skupine skupaj (obteženi $N=16626$ ).

$\mathrm{V}$ naslednji fazi nas je zanimalo, ali se dijaki, ki smo jih razdelili v posamezne skupine glede na podobnost $\mathrm{v}$ motivacijskih, metakognitivnih in učnih značilnostih, razlikujejo tudi v bralnih dosežkih. Pri tem smo uporabili izraženost bralne pismenosti is-letnikov, vključenih v raziskavo PISA 2009, z vidika treh vrst bralnega procesa:

I. Iskanje in priklic informacij.

2. Povzemanje in interpretiranje besedila.

3. Razmišljanje o prebranem in ovrednotenje prebranega. 


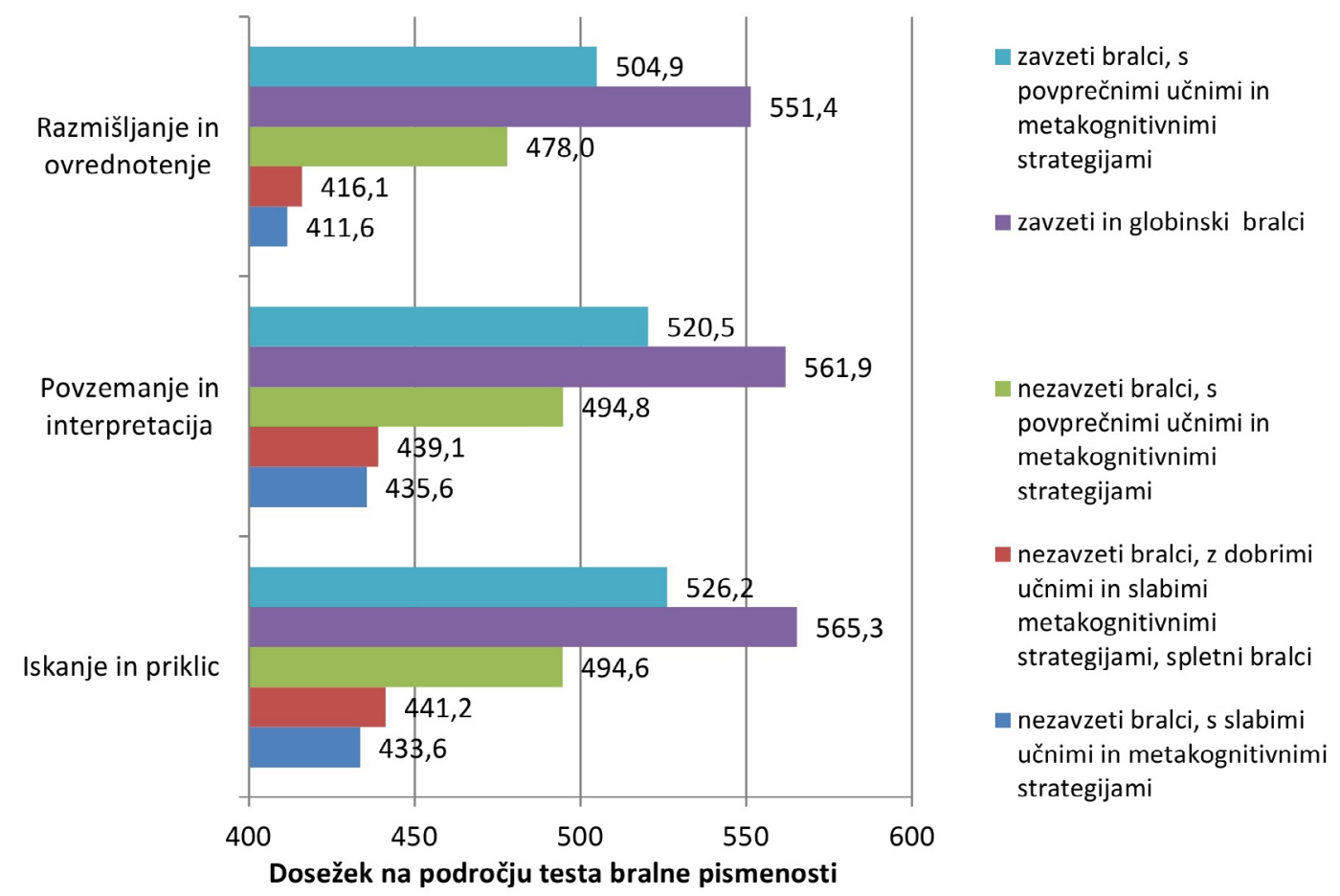

Slika 4: Dosežki na testu bralne pismenosti v petih skupinah dijakov: povprečen skupen dosežek na testu in povprečni dosežki pri posameznih vidikih bralnega procesa.

Na Sliki 4 so prikazane razlike med petimi skupinami dijakov v bralnih dosežkih z vidika bralnega procesa. Pri vseh treh vidikih bralne pismenosti z vidika bralnega procesa je opaziti podoben trend: najbolj kakovostni bralni procesi so prisotni v skupini zavzetih in globinskih bralcev. Na drugem mestu se nahaja skupina zavzetih bralcev, ki imajo povprečno razvite učne in metakognitivne strategije. Pri obeh omenjenih skupinah dosežki na področjih bralne pismenosti presegajo mejo 500 točk (povprečen dosežek slovenskih I5-letnikov v raziskavi PISA 2009 je 483 točk). Naslednja skupina po uspešnosti procesov, uporabljenih pri reševanju bralnih nalog, je skupina nezavzetih bralcev s povprečnimi učnimi in metakognitivnimi strategijami. Skupini, v katerih je prisotna najslabša kakovost bralne pismenosti z vidika bralnega procesa, sta skupini nezavzetih bralcev (s slabimi učni$\mathrm{mi}$ in metakognitivnimi strategijami - skupina $\mathrm{I}$, in z dobrimi učnimi in slabimi metakognitivnimi strategijami, spletni bralci - skupina 2). Pri omenjenih dveh skupinah so bral- 
ni dosežki še najbolj podobni (skupini se torej najmanj razlikujeta v dosežkih v primerjavi z ostalimi skupinami).

V nadaljevanju evalvacijske študije nas je potem zanimalo, kakšni so deleži profilov dijakov glede na značilnosti njihove bralne motivacije ter uporabe učnih in metakognitivnih strategij pri branju v različnih izobraževalnih programih in deleži omenjenih profilov pri fantih in dekletih ter kako se omenjene skupine razlikujejo v bralnih dosežkih.

\section{Motivacija za branje v različnih srednješolskih izobraževalnih programih}

\section{Vzorec}

V vzorec je bilo vključenih 4250 dijakov, in sicer tistih, ki smo jih vključili tudi v analize napovednikov bralnih dosežkov. $V$ tistih analizah zaradi zahtev večnivojskega modeliranja podatkov nismo upoštevali podatkov osnovnošolcev, starih is let, saj je bilo njihovo število zelo majhno $(n=30)$, kar bi lahko vplivalo na veljavnost rezultatov večnivojskih analiz, prav tako so bili iz analize izključeni dijaki 2. letnika $(n=245)$ in dijaki vseh šol, iz katerih je bilov zbiranje podatkov vključenih manj kot 5 dijakov (takih je bilo 22 šol in na njih skupno 33 preučevanih dijakov). Tako so v podatkovni bazi, na kateri smo izvajali analize v pričujočem delu študije, ostali podatki dijakov iz 27I izobraževalnih programov v okviru srednjih šol, in sicer podatki 4250 dijakov. Od tega je bilo v vzorcu 2 I 28 dijakinj (50,I \%). Povprečna starost dijakov in dijakinj je bila I5,7 I leta $(S D=0,27)$. V program srednjega poklicnega izobraževanja jih je bilo vključenih 820 (19,3 \%), v program tehničnega oz. strokovnega srednjega izobraževanja I7 I I (40,3 \%), v program strokovne gimnazije 559 $(13,2 \%)$ in v program klasične oz. splošne gimnazije i $160(27,3 \%)$ dijakov.

Njihove podatke smo ustrezno obtežili, tako da so skupno predstavljali podatke 13307 dijakov I. letnika srednjih šol. Obteženi podatki so pokazali nekoliko drugačno strukturo po izobraževalnih programih, ki je prikazana v tabeli $\mathbf{I} 3$.

Tabela iz: Struktura dijakov glede na izobraževalni program

\begin{tabular}{|l|c|}
\hline Izobraževalni program & Odstotek (od N =13307) \\
\hline I - klasična oz. splošna gimnazija & 40,0 \\
\hline 2 - strokovna gimnazija & 9,1 \\
\hline $3-$ tehnično oz. strokovno srednje izobraževanje & 39,5 \\
\hline 4 - srednje poklicno izobraževanje & 11,4 \\
\hline
\end{tabular}


Obteženi odstotek dijakinj, vključenih v analize, je znašal 52,I \%, obteženi odstotek dijakov pa $47,9 \%$.

\section{Pripomočki}

Pri ugotavljanju pomena motivacijskih, učnih in socialnih dejavnikov v različnih izobraževalnih programih v Sloveniji smo analizirali naslednja področja, ki se nahajajo v Vprašalniku za dijakinje in dijake (SŠ):

- $\quad$ osnovne lastnosti dijaka (starost, spol, izobraževalni program ...)

- družinsko ozadje (poklic in izobrazba staršev, kraj rojstva, posedovanje dolo-

čenih predmetov, npr. knjig ali računalnika)

- bralne aktivnosti zunaj šole (branje za zabavo, uživanje v branju, različnost

bralnega gradiva, spletno branje)

- Šola in učitelji (stališča do šole, odnos učiteljev do učencev)

- $\quad$ pouk slovenščine (disciplina v razredu, zaznana spodbuda učitelja $\mathrm{k}$ branju)

- knjižnice (uporaba)

- $\quad$ strategije branja in razumevanja besedil (metakognitivne strategije)

- učne strategije (kontrolne strategije, elaboriranje, memoriranje)

- uporaba IKT (informacijsko-komunikacijske tehnologije) v šoli in doma

- izobraževanje do sedaj in načrti za v prihodnje

Prav tako smo v analize vključili vprašanja o branju za šolo, ki se nahajajo v delovnih zvezkih I-I3 (interpretacija literarnih besedil, uporaba nezveznih besedil; pogostost branja tradicionalnih (literarnih) besedil, pogostost branja gradiv za funkcionalno branje).

Analizirane odvisne spremenljivke

Kot odvisne spremenljivke smo v analizo vključili WLE indekse, katerih vrednosti so že vključene v bazo PISA 2009 (OECD, 20ı ob).

Spremenljivko Branje za zabavo, izraženo v minutah na dan, smo izračunali iz spremenljivke $S_{2}{ }_{3} Q_{0}$ I, in sicer smo kategorijo I (ne berem za užitek) pretvorili v o min/dan, kategorijo 2 (berem 30 minut ali manj na dan) v $15 \mathrm{~min} /$ dan, kategorijo 3 (berem med 30 in 60 minut) v $45 \mathrm{~min} /$ dan, kategorijo 4 (berem I do 2 uri na dan) $v 90 \mathrm{~min} / \mathrm{dan}$ in kategorijo 5 (berem več kot 2 uri na dan) v 150 min/dan.

Spremenljivko Število knjig doma smo ustvarili na osnovi spremenljivke ST22QoI, in sicer smo namesto kategorij slednje izpisali sredino intervala števila knjig, ki ga predstavlja posamezna kategorija (kategorija $\mathrm{I}=5 \mathrm{knjig}$, kategorija $2=\mathrm{I} 8 \mathrm{knjig}$, kategorija $3=$ $63 \mathrm{knjig}$, kategorija $4=150,5 \mathrm{knjig}$, kategorija $5=350,5 \mathrm{knjig}$, kategorija $6=750 \mathrm{knjig})$. 
Spremenljivka HISEI predstavlja indeks poklicne ravni (Ganzeboom, de Graaf in Treiman, 1992, po OECD, 2009) tistega starša, ki ima poklic višje ravni, oz. poklicno raven dijakovega edinega starša. Višje vrednosti označujejo višjo raven poklicnega statusa.

Bralni dosežki

V analize smo vključili naslednje bralne dosežke na testu PISA 2009:

- dosežek na podlestvici iskanja in priklica informacij,

- dosežek na podlestvici povzemanja in interpretiranja besedila,

- dosežek na podlestvici razmišljanja o besedilu in vrednotenja besedila,

- dosežek na podlestvici vezanega besedila,

- dosežek na podlestvici nevezanega besedila,

- skupni bralni dosežek.

Prve tri podlestvice kažejo uspešnost učencev glede na tri vrste kognitivnih procesov med branjem. Podlestvica iskanja in priklica informacij kaže, kako dobro dijaki iščejo, izberejo in zbirajo informacije. Podlestvica povzemanja in interpretiranja besedila kaže, kako dobro dijaki prebrano besedilo miselno procesirajo, npr. poiščejo odnose med deli besedila z namenom oblikovanja smiselnega besedila. Podlestvica razmišljanja o besedilu in vrednotenja besedila pa kaže, kako dobro dijaki prebrano besedilo povezujejo z znanjem, idejami in vrednotami, ki niso zajeti v danem besedilu.

Dosežek na podlestvici vezanega besedila odraža, kako dobro dijak bere prozno besedilo, sestavljeno iz stavkov, povedi in odstavkov. Dosežek na podlestvici nevezanega besedila pa se nanaša na sposobnost branja tabel, grafov, zemljevidov in diagramov.

\section{Statistična analiza}

Za analizo smo uporabili statistični program AM. Izračunali smo deskriptivne statistike za vsako obravnavano spremenljivko glede na izobraževalni program (spremenljvko STo2 Qor v bazi podatkov PISA 2009) oziroma glede na spol (spremenljivko STo4Qor). Pri tem smo podatke obtežili z utežjo W_FSTUWT. Ta utež pomeni, koliko oseb v populaciji predstavlja posamezni dijak. Standardno napako aritmetične sredine smo ocenili po metodi balansirane ponovljene replikacije (BRR) s Fayevo modifikacijo (glej OECD, 2009: 72). V oceno smo vključili 80 replikatov uteži (W_FSTRI do W_FSTR8o) in uporabili konstanto 0,05 (ob 80 replikatih postane konstanta v enačbi replikacijske metode I/ $\left(\left(\mathrm{G}(\mathrm{I}-\mathrm{k}) \wedge^{\wedge}\right)=\mathrm{I} /\left(\left(8 \mathrm{O}^{*}(\mathrm{I}-0.5)^{\wedge} 2\right)=\mathrm{I} / 20\right)\right.$.

$\mathrm{Za}$ analizo dosežkov smo uporabili analize vrednosti verjetja (angl. plausible values), pri čemer smo upoštevali pet ocen pismenosti dijakov, merjene s skupnim dosežkom ali po po- 
sameznih podlestvicah bralnih dosežkov. Pri analizah vrednosti verjetja program izračuna določeno statistiko za vsako oceno dosežka posebej in nato povpreči dobljene statistike.

$S$ programom AM smo izračunali tudi $t$-teste za parno primerjavo mer pri dijakih in dijakinjah. Ker program AM ne omogoča izračuna analize variance, smo s $t$-testom izvedli tudi parne primerjave izobraževalnih programov, pri čemer smo uporabili Bonferronijev popravek. Zaradi šestih parnih primerjav izobraževalnih programov smo posamezno primerjavo kot statistično pomembno obravnavali takrat, ko je bila verjetnost alfa napake manjša od 0,0085I.

Za primerjavo pogostosti posameznih skupin bralcev pri dijakinjah in dijakih smo uporabili generaliziran Mantel-Haenzelov $\chi^{2}$, ki pokaže statistično pomembnost razlike med spoloma, neodvisno od (oz. povprečeno prek) ravni izobraževalnega programa.

\section{Rezultati}

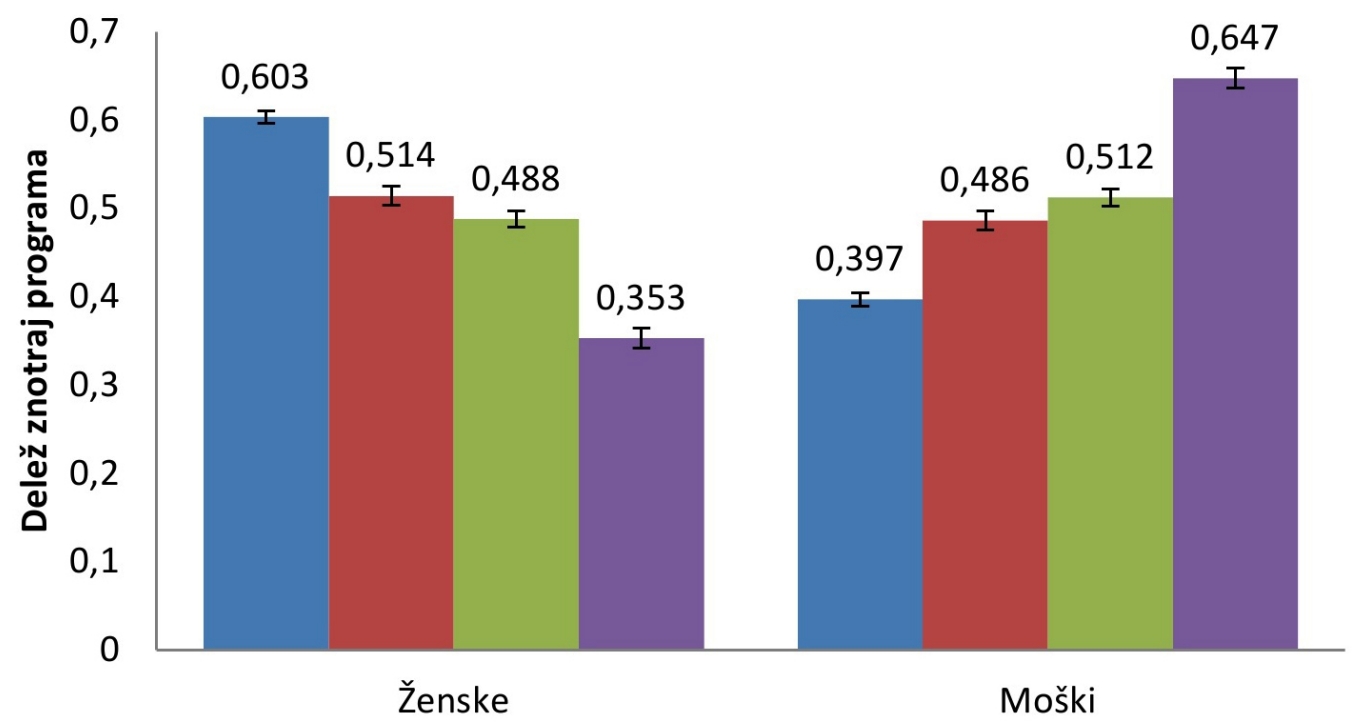

a program $1 \square$ program $2 \square$ program $3 \quad$ program 4

Slika s: Delež žensk in moških v posameznih izobraževalnih programih.

Ročaji predstavljajo 95-odstotni interval zaupanja za oceno deleža. Program I = klasična oz. splošna gimnazija, program 2 = strokovna gimnazija, program $3=$ tehnično oz. strokovno srednje izobraževanje, program 4 = srednje poklicno izobraževanje. 


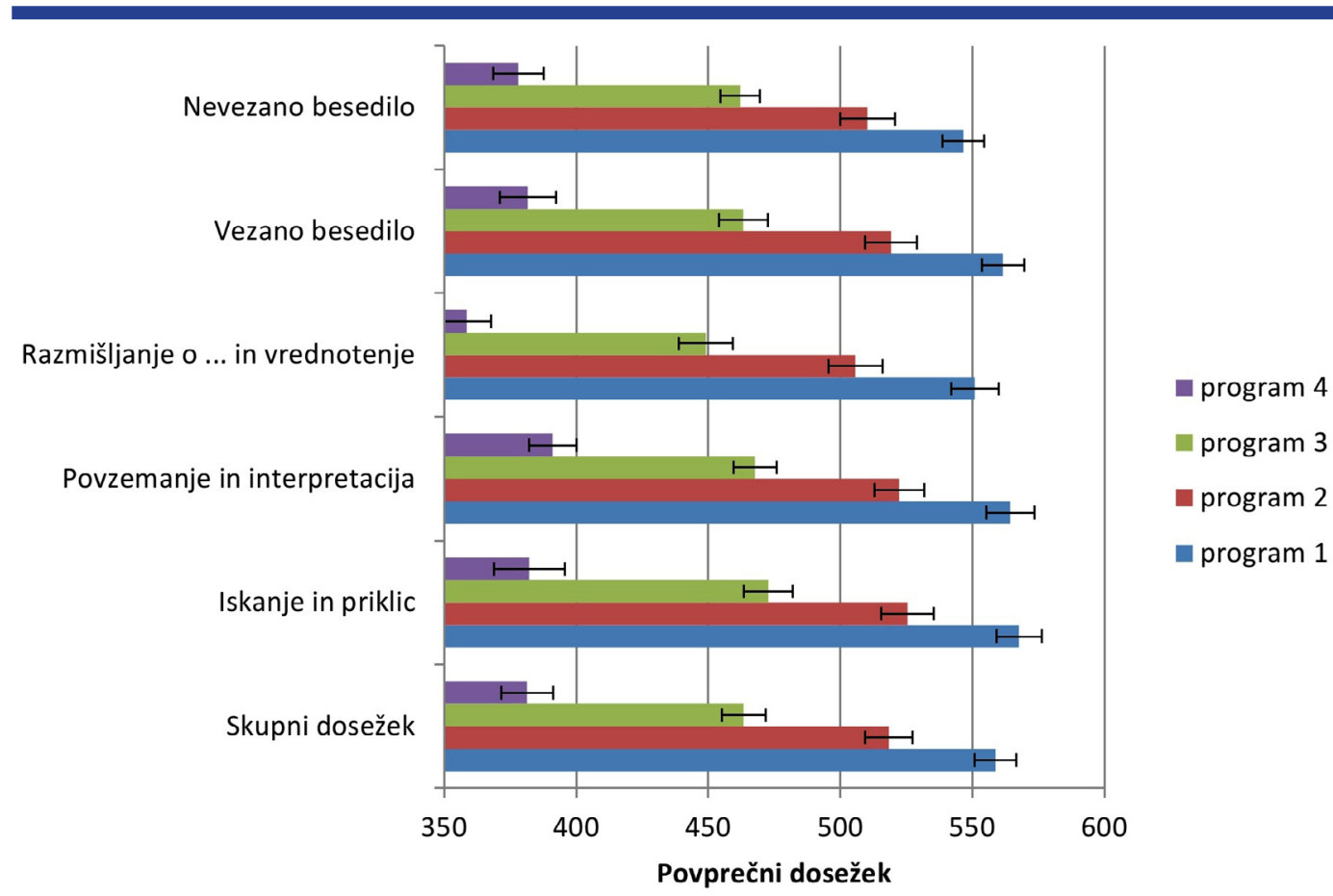

Slika 6: Aritmetična sredina in 95-odstotni interval zaupanja za aritmetično sredino skupnega dosežka in dosežkov na posameznih podlestvicah na testu PISA 2009 pri dijakih v različnih izobraževalnih programih.

Program I = klasična oz. splošna gimnazija, program 2 = strokovna gimnazija, program 3 = tehnično oz. strokovno srednje izobraževanje, program 4 = srednje poklicno izobraževanje.

Primerjava rezultatov bralnih dosežkov med različnimi programi (Slika 6) pokaže, da z nižanjem zahtevnostne ravni programa upadajo dosežki na testu PISA 2009, tako skupni dosežek kot dosežki na posameznih področjih vrst bralnega procesa, ter pri dveh oblikah besedila glede na njegovo zveznost. Intervali zaupanja za aritmetične sredine posameznih dosežkov v različnih izobraževalnih programih se ne prekrivajo, kar pomeni, da so vse parne razlike med izobraževalnimi programi na posameznih lestvicah dosežkov statistično pomembne.

Dijaki splošnih gimnazij v povprečju dosegajo četrto raven dosežkov na lestvici bralne pismenosti. To raven v splošnem dosega $24 \%$ slovenskih učencev in dijakov. V povprečju torej dijaki splošnih gimnazij pravilno razumejo daljše in kompleksno besedilo, znajo 
poiskati povezave med različnimi deli informacij, razumejo dogajanje v neznanih situacijah, uporabljajo splošno znanje, da oblikujejo predpostavke ali kritično ovrednotijo besedilo. Pri uporabi nezveznih besedil (grafi, slike, diagrami, zemljevidi) pa so njihovi dosežki nekoliko slabši in segajo nekoliko pod četrto raven dosežkov. Primerjalno so gimnazijci dosegli boljši rezultat pri reševanju nalog z zveznim kot nezveznim besedilom (prozno besedilo s stavki, odstavki). Dijaki strokovnih gimnazij so v povprečju dosegli tretjo raven dosežkov na lestvici bralne pismenosti. To raven v splošnem dosega $53 \%$ slovenskih učencev in dijakov. $\mathrm{V}$ povprečju dijaki strokovnih gimnazij znajo poiskati in v nekaterih primerih prepoznati odnos med deli informacij. Povezujejo različne dele besedila, da prepoznajo vodilno idejo in da razumejo odnose med deli besedila ali oblikujejo pomen besede ali fraze. Naloge tretje ravni dosežkov vsebujejo tudi več motečih informacij ali npr. ideje, ki nasprotujejo pričakovanjem, iskana informacija v besedilu ni nujno dobro opazna. Dijaki strokovnih gimnazij v povprečju tudi izkazujejo globlje razumevanje besedila v povezavi z vsakdanjim znanjem. Dijaki tehničnega oz. strokovnega srednjega izobraževanja v povprečju dosegajo drugo raven bralne pismenosti, ki predstavlja raven temeljnih kompetenc. To raven v splošnem dosega $79 \%$ slovenskih učencev in dijakov. Temeljne bralne kompetence se nanašajo na zmožnost iskanja ene ali več informacij z upoštevanjem različnih pogojev, prepoznavanje vodilnih idej besedila, razumevanje odnosov znotraj omejenega dela besedila, ko informacija ni očitna, primerjave na podlagi ene značilnosti besedila, povezovanje med informacijami iz besedila in lastnimi izkušnjami in znanjem. Dijaki imajo podobne dosežke pri reševanju nalog z zveznim in nezveznim besedilom. Dijaki srednjega poklicnega izobraževanja v povprečju dosegajo raven bralne pismenosti Ia. V povprečju so torej v tej skupini dijaki z dosežki pod temeljno ravnjo bralne pismenosti. Dijaki zmorejo v besedilu poiskati informacije, ki so v besedilu jasno zapisane, prepoznajo vodilno temo besedila, če je to znano, oblikujejo preprosto povezavo med informacijami iz besedila in vsakdanjim življenjem. Uspešni so lahko pri reševanju bralnih nalog, kjer je motečih informacij malo.

\section{Metakognitivne strategije}

Dijaki izobraževalnih programov se statistično pomembno razlikujejo glede na oceno uporabnosti tako metakognitivnih strategij povzemanja besedila kot tudi strategij razumevanja in pomnjenja besedila. Povprečja WLE indeksov po posameznih izobraževalnih ravneh pokažejo, da se le dijaki splošnih gimnazij nahajajo nad povprečjem OECD v oceni koristnosti uporabe metakognitivnih strategij pri branju besedila $(0,27)$, dijaki strokovnih gimnazij $(-0,07)$ so v svojih ocenah primerljivi s povprečji OECD, medtem ko se 
dijaki ostalih dveh izobraževalnih programov (strokovno srednje izobraževanje, srednje poklicno izobraževanje) na omenjenih področjih nahajajo pod povprečjem OECD (-o,37 in $-0,82$ proti $\circ, 00)$.

Dijaki, ki obiskujejo splošne gimnazije, v primerjavi z dijaki drugih programov,v največji meri ocenjujejo kot uporabne učinkovite strategije za razumevanje in pomnjenje besedila ter strategije povzemanja (0,34 proti -0,02, -0,18 in -0,59). Te strategije so učinkovite, kadar je treba informacijo $\mathrm{v}$ besedilu razumeti in si jo zapomniti ali narediti povzetek prebranega. Bralne metakogntivne strategije so tako v največji meri prisotne pri dijakih splošnih gimnazij, nato pa njihova prisotnost upada z nižanjem zahtevnostne ravni izobraževalnega programa. Najnižje so metakogntivne strategije izražene pri dijakih poklicnega srednjega izobraževanja.

\section{Uine strategije}

Med učnimi strategijami je uporaba kontrolnih strategij tista, ki narašča z zahtevnostjo izobraževalnega programa. Na drugi strani strategije memoriranja upadajo z zahtevnostjo izobraževalnega programa. Strategije elaboriranja razlikujejo med dijaki splošnih gimnazij ter srednjih poklicnih in strokovnih šol, ni pa razlik v uporabi teh strategij med dijaki splošnih in strokovnih gimnazij.

Če primerjamo dijake različnih izobraževalnih programov v uporabi učnih strategij s povprečji OECD, ugotovimo, da je uporaba kontrolnih strategij dobro zastopana v vsaj treh izobraževalnih programih (razen v srednjem poklicnem izobraževanju), saj so povprečja WLE indeksov v teh programih nad povprečjem $\operatorname{OECD~}(0,44,0,22$ in 0,05$)$. To pomeni, da slovenski dijaki v povprečju pri učenju v precejšnji meri uporabljajo strategije, kot so npr. ugotavljanje, kateri pojmi kljub prebranemu še vedno niso razumljivi, ugotavljanje, ali so si res zapomnili bistvene informacije iz besedila, iskanje dodatnih informacij, da bi pojasnili tisto, česar ne razumejo dobro. Kot je bilo že omenjeno, kontrolne strategije v največji meri uporabljajo dijaki splošnih gimnazij, nato pa njihova prisotnost upada $\mathrm{z}$ nižanjem zahtevnostne ravni izobraževalnega programa. Najnižje so kontrolne strategije izražene pri dijakih srednjega poklicnega izobraževanja. Nadalje so strategije elaboriranja v vseh izobraževalnih programih prisotne v večji meri, kot je povprečje OECD, kar pomeni, da si dijaki v različnih izobraževalnih programih prizadevajo razumeti učno gradivo tako, da ga povežejo s tem, kar že vedo, ali si prizadevajo povezovati novo učno gradivo $\mathrm{z}$ informacijami, ki se jih učijo pri drugih predmetih, ter skušajo ugotoviti uporabnost informacij v resničnosti. Strategije memoriranja so nadpovprečno (primerjalno s povprečjem OECD) prisotne v strokovnem srednjem in srednjem poklicnem izobraževanju, kar 
pomeni, da si dijaki teh šol pri učenju v veliki meri skušajo zapomniti nove informacije, da bi jih kasneje lahko obnovili na glas, in se pogosto učijo tako, da znova in znova berejo učno besedilo.

\section{Branje za solo}

V nadaljevanju smo izračunali indekse, ki se nanašajo na branje za šolo. Interpretacija bralnih tekstov pomeni pogostost branja literarnih del, razlage vzrokov dogodkov v besedilu, načina obnašanja oseb v besedilu ter namena besedila. Višji indeks pomeni več bralnih dejavnosti v učne namene. Interpretacija literarnih besedil je podobno prisotna pri dijakih splošnih in strokovnih gimnazij, v programu srednjega strokovnega izobraževanja je manj prisotna, najmanj pa v srednjem poklicnem izobraževanju. Glede na povprečje OECD so interpretacije literarnih besedil nadpovprečno prisotne $\mathrm{v}$ splošnih in strokovnih gimnazijah $(0,16$ in 0,13$)$, podpovrečno pa $\mathrm{v}$ srednjem strokovnem $(-0,15)$ in (predvsem!) poklicnem izobraževanju (-0,52).

Uporaba nezveznih gradiv pomeni pogostost uporabe besedil, ki vključujejo diagrame ali zemljevide, tabele ali grafe, iskanje podatkov z grafa, diagrama ali iz tabele ter opisovanje podatkov v tabeli ali grafu. Višji indeks pomeni več uporabe tekstov z grafičnimi prikazi. Pogostost uporabe nezveznih gradiv je v največji meri prisotna pri dijakih splošnih gimnazij, nato pa njihova uporaba upada z nižanjem zahtevnostne ravni izobraževalnega programa. Najnižje je uporaba nezveznih gradiv izražena pri dijakih srednjega poklicnega izobraževanja (-0,5I). Glede na povprečje OECD je uporaba nezveznih gradiv primerljiva OECD povprečju v splošnih gimnazijah $(0,05)$, v ostalih izobraževalnih programih pa je pod povprečjem $\left(-0, I_{2}\right.$ in -0,37). Pogostost branja tradicionalnih literarnih besedil je v gimnazij primerljiva povprečju OECD (-o,o I proti o,০o), v srednjem strokovnem in poklicnem izobraževanju pa je pod povprečjem. Prav tako dijaki splošnih in strokovnih gimnazij v večji meri berejo tradicionalno literaturo kot dijaki srednjega strokovnega in poklicnega izobraževanja (-o,or in -0,05 proti -0,32 in -0,35). Pogostost uporabe gradiv za funkcionalno branje (navodila, priročniki, oglasno gradivo) upada $z$ ravnjo zahtevnosti izobraževalnega programa. Pogostost uporabe teh gradiv je v srednjem strokovnem $(0,03)$ in poklicnem izobraževanju $(0,13)$ primerljivo ali celo nekoliko nad povprečjem OECD.

\section{Bralna motivacija}

Motivacijski vidiki bralne pismenosti se v raziskavi PISA 2009 izražajo v raznolikosti bralnega gradiva, uživanju v branju in količini časa, ki ga dijaki namenijo za branje na 
dan. Vsi omenjeni motivacijski vidiki so v največji meri prisotni pri dijakih splošnih gimnazij, bralna motivacija pa nato statistično pomembno upada $\mathrm{z}$ nižanjem zahtevnostne ravni izobraževalnega programa. Če primerjamo vidike bralne motivacije med slovenskimi dijaki različnih izobraževalnih programov in povprečji OECD, ugotovimo, da je raznolikost gradiva, ki ga dijaki berejo, nad povprečjem OECD pri dijakih splošnih in strokovnih gimnazij $(0,25$ in 0,14$)$. Pod povprečjem OECD se v raznolikosti bralnega gradiva nahajajo le dijaki srednjega poklicnega izobraževanja (-o,19). Na drugi strani je uživanje v branju nadpovprečno prisotno le pri dijakih splošnih gimnazij $(0,23)$, pod povprečjem OECD pa v branju uživajo dijaki ostalih izobraževalnih programov (izrazito pod povprečjem OECD predvsem dijaki srednjega poklicnega izobraževanja) (-o, I 4, $0,37$ in $-0,60)$.

\section{Pouk slovenšcine}

Pouk slovenščine je bil v raziskavi PISA 2009 raziskan $\mathrm{z}$ vidika učiteljevih spodbud $\mathrm{k}$ branju ter discipline $\mathrm{v}$ razredu.

Zaznana učiteljeva spodbuda pri branju označuje, v kolikšni meri učitelj pri pouku slovenščine spodbuja dijake, tj. zahteva, da pojasnijo pomen besedila; z vprašanji spodbuja k boljšemu razumevanju besedila; jim da dovolj časa, da razmislijo; priporoči v branje kakšno knjigo; jih spodbuja, da izrazijo svoje mnenje o besedilu; jim pomaga povezati brane zgodbe z njihovim življenjem; pokaže, kako informacije iz besedil nadgrajujejo njihovo predhodno znanje. Dijaki v splošnih gimnazijah v največji meri zaznavajo svojega učitelja kot takšnega, ki jih spodbuja k branju, vendar se v svojih ocenah ne razlikujejo od dijakov strokovnih gimnazij (o,32 proti o,27). Dijaki strokovnega srednjega in poklicnega strokovnega izobraževanja $\mathrm{v}$ pomembno manjši meri zaznavajo spodbude učitelja slovenščine $\mathrm{k}$ branju kot njihovi vrstniki v gimnazijah (0,20 in 0,05 proti 0,32). Zanimivo je, da dijaki vseh štirih izobraževalnih programov nadpovprečno (glede na povprečje OECD) ocenjujejo učiteljeve spodbude $\mathrm{k}$ branju.

Disciplino v razredu pri pouku slovenščine najbolj pozitivno ocenjujejo dijaki splošnih in strokovnih gimnazij (ni razlik med skupinama), disciplino v razredu pa najslabše zaznavajo dijaki srednjega poklicnega izobraževanja. Glede na povprečje OECD je disciplina pri pouku podpovprečno prisotna $\mathrm{v}$ izobraževalnih programih srednjega strokovnega in poklicnega izobraževanja (-0,25 in -0,56 proti o,oo), medtem ko je v obeh vrstah gimnazij prisotna nadpovprečno $(0,26$ in 0,25$)$. 
Uporaba IKT

V raziskavi PISA 2009 je bila uporaba IKT pri Is-letnikih preverjana z različnih vidikov: raziskovalci so v vprašalnik vključili vprašanja o dostopnosti IKT v šoli in doma, pogostosti uporabe računalnika za šolsko delo doma in v šoli, uporabi IKT za zabavo, spletnem branju, samoučinkovitosti pri uporabi IKT ter stališčih do računalnika.

Rezultati kažejo bistveno razliko med dostopnostjo računalnikov doma in v šoli. Dijaki vseh štirih izobraževalnih programov $\mathrm{v}$ primerjavi s povprečjem OECD poročajo o podpovprečni dostopnosti IKT v šoli (računalnik, povezava z internetom, tiskalnik), zlasti se pod povprečjem $s$ svojimi ocenami dostopnosti nahajajo dijaki v strokovnih gimnazijah (-o,4I proti o,oo). Na drugi strani je dostopnost IKT doma (računalnik, internet, brezžični telefon, glasbeni predvajalniki, video igre ...) primerljiva s povprečjem OECD. Primerjalno med izobraževalnimi programi dijaki srednjih poklicnih šolv najmanjši meri poročajo o dostopnosti IKT doma.

Uporaba računalnika v šoli označuje, kako pogosto dijak v šoli uporablja računalnik za različne namene (klepet prek spleta; uporaba elektronske pošte; iskanje informacije za šolsko delo; nalaganje gradiv $s$ spletne strani šole ali brskanje po njej; uporaba računalniških simulacij; vaja in izpopolnjevanje pri različnih predmetih; samostojno opravljanje domače naloge; uporaba za skupinsko delo in stike z drugimi dijaki). Izstopajo dijaki splošnih gimnazij, ki v primerjavi s povprečjem OECD uporabljajo računalnik $v$ šoli v manjši meri (-o,I9 proti o,o०), dijaki poklicnih šol pa so v uporabi računalnikov v šoli nad povprečjem OECD (o, I proti o,oo). Primerjalno med izobraževalnimi programi računalnik $\mathrm{v}$ šoli v največji meri uporabljajo dijaki srednjega poklicnega izobraževanja (o,II), najmanj pa dijaki splošnih gimnazij $(-0,19)$. Nadalje je pogostost uporabe računalnika doma za naloge, povezane s šolo, na vseh ravneh izobraževanja nad povprečjem OECD. Računalnik doma za potrebe šolskega učenja v največji meri uporabljajo dijaki strokovnih gimnazij $(0,46)$ (kar je razumljivo, saj so med njimi dijaki tehniške gimnazije).

Spletno branje je v treh izobraževalnih programih (gimnazije, strokovno srednje izobraževanje) nadpovprečno (v primerjavi s povprečjem OECD). Gre za branje elektronske pošte, uporabo spletnih klepetalnic, branje spletnih novic, uporabo slovarjev, iskanje spletnih informacij, sodelovanje v skupinskih razpravah na spletu. Najbolj pogosti spletni bralci so dijaki obeh vrst gimnazij ( 0,39 in 0,45 proti), najmanj pa berejo na spletu (čeprav še vedno v okviru povprečja OECD) dijaki poklicnih šol (-o,oI). Dijaki v različnih izobraževalnih programih tudi nadpovprečno (primerjava s povprečjem OECD) uporabljajo IKT in internet za zabavo $(0,24,0,46,0,55$ in 0,59 proti 0,00$)$. Hkrati se dijaki v vseh izo- 
braževalnih programih (primerjava s povprečjem OECD) ocenjujejo kot visoko učinkoviti oz. zmožni opravljati IKT naloge visoke ravni, kot so preurejanje digitalnih fotografij, uporaba preglednic, priprava predstavitve, priprava multimedijske predstavitve. Pri zaznani samoučinkovitosti na področju IKT najbolj izstopajo dijaki strokovnih gimnazij $(0,30)$ ter srednjega strokovnega izobraževanja $(0,32)$. Stališča do dela z računalnikom so pri dijakih vseh izobraževalnih smeri nadpovprečno pozitivna, še zlasti pri dijakih strokovnih gimnazij ter srednjega strokovnega izobraževanja.

\section{Uporaba knjiznice}

Dijaki različnih izobraževalnih programov se ne razlikujejo v uporabi knjižnice. Uporaba knjižnice je nadpovprečno prisotna pri dijakih vseh programov (glede na povprečje OECD).

\section{Stališča do šole}

Stališče do šole označuje dijakovo splošno mnenje o šoli (ga je dobro pripravila na življenje; je bila izguba časa; mu je pomagala pri pridobivanju samozavesti za sprejemanje odločitev; ga je naučila stvari, ki bi bile lahko koristne pri opravljanju poklica). Zanimivo je, da imajo najbolj ugodno stališče o šoli dijaki srednjega strokovnega izobraževanja, sledijo dijaki srednjega poklicnega izobraževanja, najmanj ugodno stališče o šoli pa imajo dijaki splošnih in strokovnih gimnazij (ni razlik med skupinama). Pri slednjih so stališča do šole pod povprečjem OECD. Še zlasti je to zaskrbljujoče, ker trditve pri omenjenem indeksu opisujejo, v kolikšni meri dijak zaznava šolo kot ustanovo, ki ga je pripravila na odraslo življenje, ga naučila stvari, ki so koristne pri opravljanju poklica, ter mu pomagala pri razvijanju samozavesti.

\section{Družinsko okolje}

Dijaki različnih izobraževalnih programov se razlikujejo v značilnostih družinskega okolja. Z nižanjem zahtevnostne ravni izobraževalnega programa upada izobrazbena raven očeta in matere, poklicni status staršev, socialno-ekonomsko-kulturni status družine povprečnega dijaka na šoli, raven kulturnih dobrin doma, dosegljivost izobraževalnih virov doma ter število knjig doma. Kljub temu pa so, v primerjavi s povprečjem OECD, v vseh izobraževalnih programih nadpovprečno prisotni domači izobraževalni viri (pisalna miza, računalnik, izobraževalni računalniški programi, knjige za šolsko delo, tehnični priročniki, slovarji) $(0,34,0,36,0,2 \mathrm{I}$ in 0,06 proti 0,00$)$. 


\section{Primerjava bralnih dosežkov skupin bralcev v različnih izobraževalnih programih}

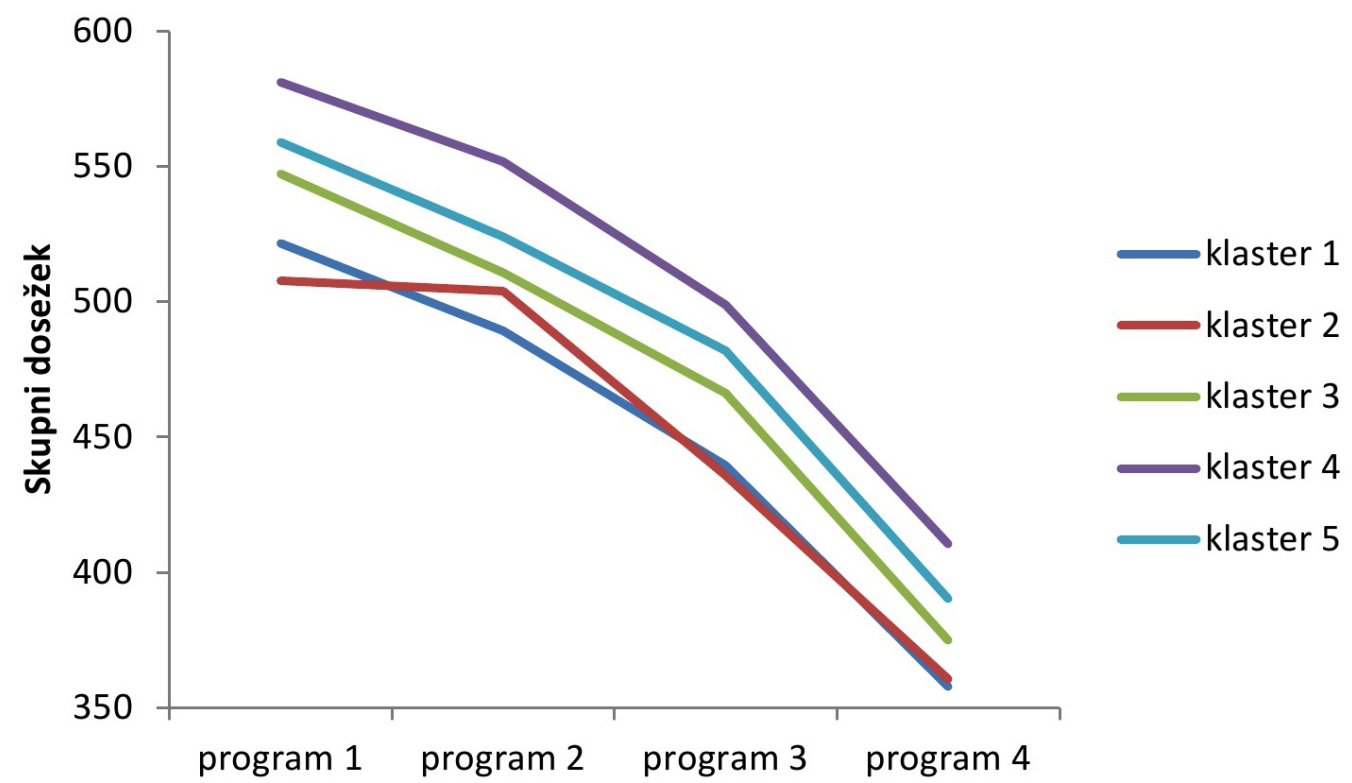

Slika 7: Primerjava skupnega dosežka različnih skupin bralcev iz različnih izobraževalnih programov.

Opombe: klaster $\mathrm{I}=$ nezavzeti bralci s slabimi učnimi in metakognitivnimi strategijami; klaster 2 = nezavzeti bralci z dobrimi učnimi in slabimi metakognitivnimi strategijami; spretni bralci; klaster 3 = nezavzeti bralci s povprečnimi učnimi in metakognitivnimi strategijami; klaster 4 = zavzeti in globinski bralci; klaster 6 = zavzeti bralci s povprečnimi učnimi in metakognitivnimi strategijami. Program I = klasična oz. splošna gimnazija, program 2 = strokovna gimnazija, program 3 = tehnično oz. strokovno srednje izobraževanje, program $4=$ srednje poklicno izobraževanje.

Odnose med skupinami bralcev v različnih izobraževalnih programih prikazuje Slika 7. Vidimo lahko, da so krivulje klastrov I, 3, 4 in 5 bolj kot ne vzporedne, kar pomeni, da se dosežki v vseh štirih klastrih spremenijo za podobno količino, ko se spremeni izobraževalni program. Z drugimi besedami, dosežki zavzetih in globinskih bralcev (dosežki klastra 4) se v izobraževalnem programu i za podobno količino razlikujejo od dosežkov ne- 
zavzetih bralcev s slabimi učnimi in metakognitivnimi strategijami (dosežkov klastra r), kot se razlikujejo tudi v izobraževalnem programu 2, 3 ali 4. Drugače pa je pri klastru 2 oz. nezavzetih bralcih z dobrimi učnimi in slabimi metakognitivnimi strategijami. Ti imajo v izobraževalnem programu I najnižje dosežke na vseh preučevanih področjih, medtem ko imajo, če se izobražujejo v programih 2, 3 in 4, dosežke, ki so podobni ali višji od dosežkov klastra I oz. dosežkov nezavzetih bralcev s slabimi učnimi in metakognitivnimi strategijami (vendar razlike med klastroma niso bile statistično pomembne). Zdi se, kot da bi imeli nezavzeti bralci z dobrimi učnimi strategijami, a slabimi metakognitivnimi strategijami v izobraževalnem programu i nekoliko nižjo bralno pismenost (po dosežkih bolj odstopajo od drugih bralcev, in sicer v negativno smer), kot jih imajo v drugih izobraževalnih programih. Morda v programu I dijaki, ki imajo sicer slabše učne in metakognitivne strategije, več berejo, ker morajo učenju posvečati več pozornosti, zato je tudi njihova bralna pismenost višja od pismenosti bralcev iz klastra 2 , ki imajo od njih boljše učne strategije, in zato hitreje usvajajo znanje ter jim je treba zato manj brati.

\section{Motivacija za branje glede na spol}

Rezultati

Tabela I4: Primerjava dijakinj in dijakov po dosežkih na testu bralne pismenosti

\begin{tabular}{|l|c|c|c|c|}
\hline & \multicolumn{2}{|c|}{ dijakinje (nw 6929$)$} & \multicolumn{2}{c|}{ dijaki (nw 6355$)$} \\
\hline Lestvice dosežkov & $\mathrm{M}$ & $95 \% \mathrm{IZ}$ za M & $\mathrm{M}$ & $95 \%$ IZza M \\
\hline Skupni dosežek & 517,73 & $506,46-529,0 \mathrm{I}$ & 474,94 & $464,08-485,80$ \\
\hline Iskanje in priklic & 525,83 & $515,50-536,16$ & 482,84 & $471,22-494,46$ \\
\hline Povzemanje in interpretacija & 520,90 & $509,9 \mathrm{I}-53 \mathrm{I}, 89$ & 482,77 & $471,95-493,59$ \\
\hline Razmišljanje o.. in vrednotenje & 509,15 & $497,68-520,62$ & 458,03 & $446,23-469,83$ \\
\hline Vezano besedilo & $520,8 \mathrm{I}$ & $509,58-532,04$ & 474,06 & $462,82-485,30$ \\
\hline Nevezano besedilo & 507,04 & $496,36-517,72$ & 473,04 & $462,60-483,48$ \\
\hline
\end{tabular}

Opombe: $I Z$ = interval zaupanja.

Primerjava dijakinj in dijakov po dosežkih na testu bralne pismenosti (Tabela I 4) pokaže, da imajo dijakinje višje dosežke od dijakov tako pri skupnem bralnem dosežku kot pri dosežkih na posameznih področjih vrst bralnega procesa ter pri dveh oblikah besedila glede na njegovo zveznost. V povprečju so dekleta dosegla tretjo raven dosežkov na lestvici bralne pismenosti, fantje pa drugo (temeljno) raven. Zanimivo je, da so dekleta bolje re- 
ševala naloge z zveznim kot nezveznim besedilom, pri fantih pa med reševanjem obeh vrst nalog ni bilo razlik. Dekleta kažejo najboljšo uspešnost pri nalogah, ki so zahtevale iskanje in priklic informacij, fantje pa so podobno uspešno reševali naloge iskanja in priklica informacij ter naloge povzemanja in interpretacije besedila.

Nadaljnje analize so pokazale tudi, da v primerjavi z dijaki dijakinje:

- besedilo bolj povzemajo, ga berejo z razumevanjem in pomnjenjem,

- pri učenju bolj uporabljajo kontrolne strategije ter memoriranje, manj pa besedila, ki se jih učijo, elaborirajo,

- več interpretirajo literarna gradiva ter poročajo o večji pogostosti branja tradicionalne literature, medtem ko dijaki poročajo o prebiranju več gradiv za funkcionalno branje,

- bolj raznoliko berejo,

- bolj uživajo ob branju,

- zaznavajo več spodbude učitelja k branju,

- ocenjujejo, da je disciplina v razredu višja,

- poročajo o nižji dostopnosti IKT v šoli, manj uporabljajo IKT v šoli, manj uporabljajo IKT za naloge, povezane s šolo, manj berejo na spletu, manj uporabljajo IKT in internet za zabavo, imajo manj pozitivna stališča do računalnikov in tudi nižjo samoučinkovitost za zahtevnejše naloge z IKT,

- bolj uporabljajo knjižnico,

- imajo manj negativna stališča do šole,

- poročajo, da so se njihovi očetje oz. matere manj časa šolali,

- poročajo o nižjem socialno-ekonomsko-kulturnem statusu njihove družine,

- poročajo tudi, da izhajajo iz manj premožnih družin kot dijaki, da imajo doma manj splošnih dobrin, slabše naj bi jim bile dostopne tudi IKT doma, vendar pa poročajo tudi o nekaj več kulturnih dobrinah in virih za učenje.

V Tabeli is lahko razberemo, da sta pri dekletih prevladujoči skupini zavzetih bralk (klastra 4 in 5), medtem ko pri dijakih prevladuje skupina Nezavzeti bralci, s povprečnimi učnimi in metakognitivnimi strategijami, močneje kot pri dijakinjah sta izražena tudi klastra $\mathrm{I}$ in 2, tj. skupini nezavzetih bralcev. Razlika med spoloma je statistično pomembna, generaliziran Mantel-Haenzelov $\chi^{2}(3)=136,54, p<0,00 \mathrm{I}$. 
Tabela is: Primerjava odstotkov posameznih skupin bralcev pri dijakinjah in dijakih

\begin{tabular}{|l|c|c|c|c|}
\hline & \multicolumn{2}{|c|}{ dijakinje $(\mathrm{n}=6932)$} & \multicolumn{2}{c|}{ dijaki(n=6373) } \\
\hline & $\%$ & $95 \% \mathrm{IZza} \%$ & $\%$ & $95 \%$ IZ za \% \\
\hline klaster I & 8,5 & $7,8-9,2$ & 18,5 & $17,7-19,3$ \\
\hline klaster 2 & 10,0 & $9,3-10,7$ & 18,8 & $17,8-19,8$ \\
\hline klaster 3 & 22,4 & $21,4-23,4$ & 36,0 & $34,7-37,3$ \\
\hline klaster 4 & 29,9 & $28,7-31,1$ & 11,5 & $10,7-12,3$ \\
\hline klaster 5 & 29,3 & $28,2-30,4$ & 15,2 & $14,2-16,2$ \\
\hline
\end{tabular}

Opombe: klaster I = Nezavzeti bralci, s slabimi učnimi in metakognitivnimi strategijami; klaster 2 = Nezavzeti bralci z dobrimi učnimi in slabimi metakognitivnimi strategijami, spletni bralci; klaster 3 = Nezavzeti bralci, $s$ povprečnimi učnimi in metakognitivnimi strategijami; klaster $4=$ Zavzeti in globinski bralci; klaster $5=$ Zavzeti bralci, s povprečnimi učnimi in metakognitivnimi strategijami.IZ = interval zaupanja.

\section{Primerjava dosežkov dijakinj in dijakov v različnih skupinah bralcev}

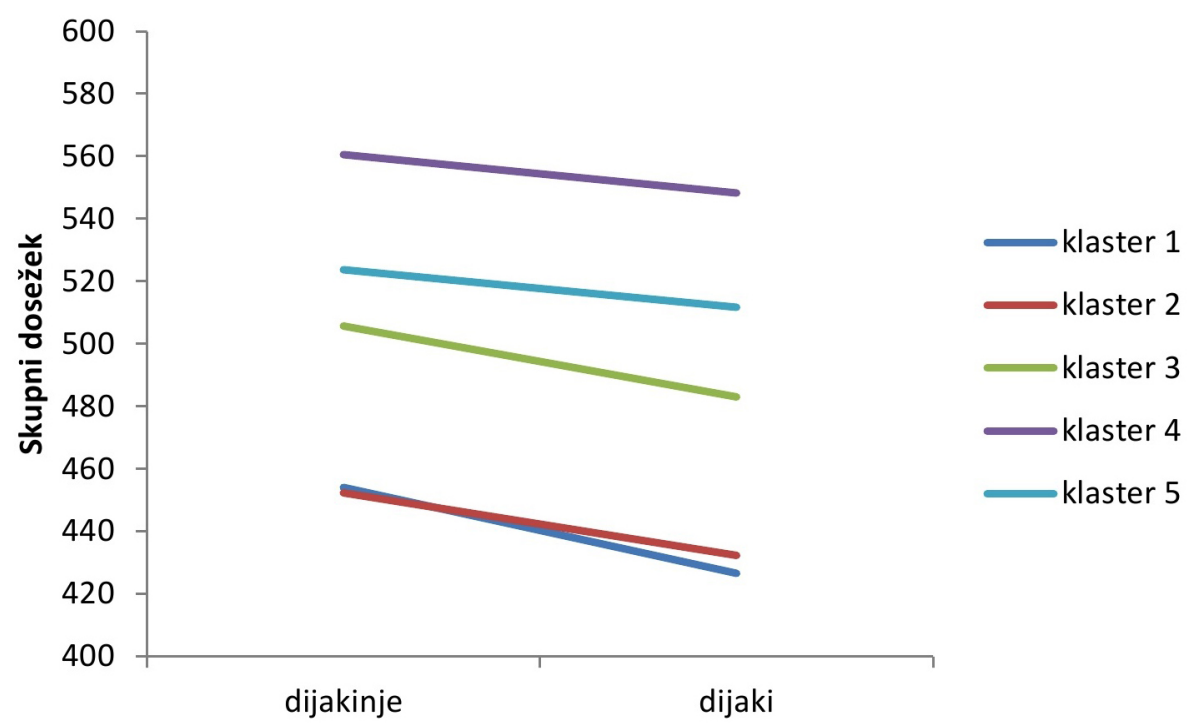

Slika 8: Primerjava skupnega dosežka dijakinj in dijakov iz različnih skupin bralcev.

Opombe: klaster I = nezavzeti bralci s slabimi učnimi in metakognitivnimi strategijami; klaster 2 = nezavzeti bralci z dobrimi učnimi in slabimi metakognitivnimi strategijami; spretni 
bralci; klaster $3=$ nezavzeti bralci s povprečnimi učnimi in metakognitivnimi strategijami; klaster 4 = zavzeti in globinski bralci; klaster 6 = zavzeti bralci s povprečnimi učnimi in metakognitivnimi strategijami.

Na Sliki 8 je prikazano, kakšni so bili na različnih področjih dosežki dijakinj in kakšni dosežki dijakov, ki pripadajo različnim skupinam bralcev. Vidimo lahko, da so imele na splošno v vseh skupinah bralcev (v vseh klastrih) dijakinje višje dosežke od dijakov. Dosežki dijakinj iz klastrov $\mathrm{I}$ in 2 so bili razmeroma izenačeni in enako velja tudi za dosežke dijakov iz teh dveh klastrov.

Iz tega bi morda lahko sklepali, da učne strategije (v katerih se razlikujeta klastra I in 2) na splošno niso pomemben razlikovalni dejavnik dosežkov na testu PISA 2009, vsaj ne pri dijakih, ki imajo obenem slabe metakognitivne strategije.

\section{Diskusija in praktične implikacije}

\section{Primerjava motivacijskih, ucnih in socialnih dejavnikov bralne pismenosti na}

Finskem, Norveškem in v Sloveniji

$\mathrm{V}$ raziskavi smo analizirali razlike $\mathrm{v}$ odnosu 15 -letnikov do branja, tradicionalnih in spletnih bralnih aktivnostih, $\mathrm{v}$ uporabi učnih in metakognitivnih strategij pri branju ter $\mathrm{v}$ značilnostih učnega okolja v treh državah. Slovenske is-letnike smo na omenjenih spremenljivkah primerjali s finskimi in norveškimi, saj se Finska in Norveška uvrščata med najuspešnejše evropske države v mednarodni raziskavi znanja PISA 2009. Medtem ko se Finska z bralnimi dosežki I 5 -letnikov uvršča v sam vrh lestvice (skupaj s Šanghajem, Južno Korejo, Hong Kongom), se je Norveška uvrstila na I 2. mesto, za to državo pa je zlasti pomembno, da je svoj dosežek na področju pismenosti izboljšala med letoma 2006 in 2009 (OECD, 20Iоa). Proučevanje razlik v omenjenih motivacijskih, učnih in socialnih dejavnikih bralne pismenosti med državami ter primerjava učinkov omenjenih dejavnikov na bralno pismenost znotraj primerjanih držav lahko predstavljajo idejno podlago za oblikovanje smernic izboljševanja motivacijskih in učnih vidikov bralne pismenosti med slovenskimi I -letniki. Ugotovljena struktura bralnih aktivnosti mladostnikov v najuspešnejših evropskih »družbah znanja« je tako lahko v pomoč pri vzpostavljanju nacionalnih strategij izboljševanja motivacije za učenje in branje.

Primerjalna analiza bralnih aktivnosti med tremi državami je pokazala, da je količina časa, ki ga dijaki namenjajo branju v prostem času, pomembno povezana z bralnimi dosežki tako v Slovenji kot tudi na Finskem in Norveškem. Hkrati pa analiza opozarja na dejstvo, da bralni dosežki ne naraščajo premosorazmerno s količina časa branja. V vseh pri- 
merjanih državah je bralni dosežek najvišji pri dijakih, ki berejo na dan I do 2 uri, največja pa je razlika v bralnem dosežku med Is-letniki, ki sploh ne berejo za zabavo, ter njihovimi vrstniki, ki berejo približno pol ure na dan. Na osnovi primerjalne analize sklepamo, da jev mladostnikovem vsakdanjem življenju zelo pomembno, da sprejme branje kot eno svojih prostočasnih aktivnosti ter vsakodnevno bere za zabavo, pa čeprav le nekaj minut. Branje za zabavo pomeni, da posameznik poseže po bralnem gradivu brez zunanje ali notranje prisile, torej da v branju uživa. Učenci, ki uživajo v branju, pa imajo tudi boljše bralne kompetence (Schiefele, 2009). V primerjalni analizi treh držav smo ugotovili, da slovenski dijaki v večji meri kot njihovi finski in norveški vrstniki berejo le zato, da dobijo potrebne informacije, in berejo le, če morajo. Slab odnos do branja je na sploh zaslediti tudi v primerjalnih dveh državah in v povprečju OECD, kar verjetno odraža univerzalen upad bralne motivacije v obdobju mladostništva. Rezultati pa tudi kažejo, da je indeks uživanja v branju močan napovednik bralne pismenosti, njegova moč napovedovanja pa je na Finskem in Norveškem še višja kot v Sloveniji. Na Finskem je tudi zaznati, da so finski mladostniki bolj notranje motivirani za branje $\mathrm{v}$ primerjavi s povprečjem OECD in povprečjem slovenskih I5-letnikov pri omenjenih trditvah (branje kot najljubši konjiček, vesel, če za darilo dobi knjigo, izmenjava mnenja o prebranih knjigah). Sklepamo labko, da je pri slovenskib mladostnikih nadpovprečno prisotna zunanja motivacija za branje (berejo takrat, ko morajo), pa tudi odpor do branja (branje kot izguba časa, knjigo prebere s težavo), manj pa je prisotno pristno uživanje $v$ branju. Omenjen rezultat zahteva globljo analizo vzrokov, zakaj je branje za dobršen delež slovenskih mladostnikov prej prisila kot užitek. V slovenskem prostoru je kultura branja zagotovo prisotna (kaže se v družbenem spodbujanju branja otrok že v najzgodnejših obdobjih življenja, kulturi bralne značke od vrtca naprej, domačem branju v šoli, razvejani mreži knjižnic, tako splošnoizobraževalnih kot šolskih, bralnih kotičkih ipd.). Vendar pa spodbujanje zanimanja in uživanja v branju ne bi smelo pomeniti le spodbude $\mathrm{k}$ čim več branja in poseganju po literaturi, ki jo predpišejo avtoritete (učitelji, starsi), ampak je treba pri bralnih spodbudah izhajati predvsem iz otrokovih interesov in prilagajati tip bralnih aktivnosti njegovim zanimanjem. Pomemben je podatek iz primerjalne analize, da slovenski dijaki manj pogosto berejo leposlovje na lastno željo, kot je povprečje OECD. Čeprav sta tudi Finska in Norveška pri omenjenem vprašanju pod povprečjem, je odstotek tistih mladostnikov v teh državah, ki berejo leposlovje na lastno željo, bistveno višji kot v Sloveniji. Zanimivo je, da slovenski I5-letniki visoko prednjačijo v pogostnosti branja drugega bralnega gradiva (revije, časopisi, knjige, ki niso leposlovje) tako glede na primerjane vrstnike na Finskem in Norveškem kot tudi glede na povprečje OECD. Slovenski mladostniki so torej še v večji meri kot njihovi vrstniki v OECD ter specifično v 
skandinavskih državah navdušeni nad bralnim gradivom, ki ni klasična literatura. Pristno zanimanje za branje bi bilo $v$ Sloveniji verjetno dobro razvijati z raznovrstnim (ne le leposlovnim) bralnim gradivom, ki bi v večji meri sledilo zanimanjem mladostnikov. Hkratipa je pomembna ugotovitev raziskave, da imajo dijaki, ki v večji meri berejo raznovrstno gradivo, vključujoč leposlovje, boljše bralne dosežke. Poleg omogočene samostojne izbire bralnih gradiv je zato $v$ Sloveniji pomembno vprašanje, kako navdušiti mlade tudi za bralno zahtevnejse (leposlovno) gradivo. Raznovrstnost bralnega gradiva ne pomeni le branja gradiva $\mathrm{v}$ tiskani obliki, ampak se angažiranost pri branju v sodobnem svetu kaže tudi v branju gradiva, ki ga najdemo na spletu. Primerjalna analiza je pokazala, da za vse tri države velja naslednja ugotovitev: I5-letniki, ki se pogosteje ukvarjajo z bralnimi aktivnostmi na spletu, dosegajo tudi višje bralne dosežke, vendar ne, če se s tem ukvarjajo v zelo veliki meri. Ugotavljamo pa tudi, da v Sloveniji prevladuje branje na spletu, ki sodi v kategorijo prostočasnega branja (branje elektronske pošte, spletne klepetalnice, branje spletnih novic), manj je prisotno spletno branje za namene pridobivanja znanja (uporaba spletnega slovarja, iskanje spletnih informacij).

Primerjalna analiza je pokazala tudi na nekatere razlike v uporabi metakognitivnih strategij med Is-letniki treh primerjanih držav. V splošnem lahko rečemo, da v povprečju dijaki na Norveškem in Finskem zaznavajo večjo pomembnost in uporabnost učinkovitih strategij povzemanja besedila kot dijaki v Sloveniji. V vseh treh primerjanih državah dijaki, ki omenjene strategije in njihovo uporabo pri učenju ocenjujejo kot pomembnejše, v povprečju dosegajo tudi višje dosežke na testu bralne pismenosti. Tako se lahko slovenski dijaki, ki zaznavajo večjo uporabnost učinkovitih strategij povzemanja besedila kot tri četrtine njihovih vrstnikov, v povprečju s svojimi bralnimi dosežki primerjajo s povprečjem najuspešnejših držav na področju bralne pismenosti v raziskavi PISA 2009. Podobno dijaki v vseh treh državah, ki v večji meri ocenjujejo uporabnost učinkovitih strategij razumevanja in pomnjenja besedila, dosegajo tudi višje bralne dosežke. Na podlagi zgoraj navedenih podatkov labko zaključimo, da zavedanje uporabnosti učinkovitih strategij razumevanja, pomnjenja in povzemanja besedila strani dijakov predstavlja pomemben dejavnik pojasnjevanja bralnih dosežkov. Dijaki, ki imajo v večji meri razvito védenje o tem, katere bralne strategije povzemanja besedila je dobro uporabiti, ko se soočajo z zahtevnejšim ali daljšim besedilom, ter katere strategije so ustrezne, ko je neko besedilo treba razumeti in si ga zapomniti, tudi uspešneje razvijajo bralno pismenost. V slovenskem prostoru se trenutno izvajata vsaj dva obsežnejša projekta, v katerih strokovnjaki ZRŠŠ skupaj z učitelji na osnovnih in srednjih šolah razvijajo učinkovite bralne strategije pri učencih. Tudi izsled- 
ki naše raziskave potrjujejo potrebnost opolnomočenja učencev z naborom različnih bralnih strategij, ki jih potem ti uporabljajo glede na značilnosti učnega konteksta ter prvin lastnega učnega sloga.

Za razliko od metakognitivnih strategij so se učne strategije memoriranja, elaboracije in kontrolnih strategij pokazale kot šibek dejavnik pojasnjevanja bralnih dosežkov v vseh treh primerjanih državah. Medtem ko so vrednosti vseh treh indeksov učnih strategij podpovprečne na Finskem in Norveškem, se v Sloveniji omenjeni indeksi nahajajo v povprečju ali nekoliko nad povprečjem. Čeprav imajo strategije elaboracije naučenega in strategije nadzora nad razumevanjem prebranega pozitiven učinek na bralno pismenost, je ta učinek nižji kot učinek metakognitivnih strategij (zaznavanje uporabnosti strategij, ne nujno njihove dejanske uporabe) in učinek motivacijskih vidikov branja (uživanje v branju, raznovrstnost bralnega gradiva). Primerjalna analiza tudi pokaže, da so (vsaj z vidika samozaznave) učne strategije pri slovenskih 15-letnikih dokaj dobro zastopane.

V nadaljevanju smo analizirali socialni kontekst bralne pismenosti - stališča I5-letnikov do šole in pouka materinščine. Rezultati raziskave PISA 2009 na mednarodni ravni kažejo, da so pozitivni odnosi med učitelji in učenci, učiteljeve spodbude k aktivnem sodelovanju pri pouku ter boljša disciplina v razredu povezani z višjimi bralnimi dosežki.

Čeprav je povprečna vrednost indeksa discipline v razredu v Sloveniji nižja, kot je na ravni povprečja OECD, pa je na Finskem in Norveškem disciplina v razredu še slabša (kar odražajo nadpovprečno nizke vrednosti indeksa za omenjeni državi). Zaznana disciplina v razredu je pri slovenskih I5-letnikih močneje povezana z bralnim dosežkom, kot je to ugotovljeno za Finsko in Norveško. Slovenski is-letniki tudi v večji meri zaznavajo več učiteljeve spodbude pri pouku materinščine kot njihovi vrstniki v obeh skandinavskih državah. Tako slovenski I 5 -letniki v večji meri kot njihovi skandinavski vrstniki menijo, da profesor od njih zahteva, da pojasnijo pomen besedila, jim zastavlja vprašanja, ki spodbujajo $\mathrm{k}$ boljšemu razumevanju besedila, spodbuja dijake, da izrazijo svoje mnenje o besedilu, pomaga povezovati zgodbe, ki jih dijaki berejo, z vsakdanjim življenjem ter prikazuje povezanost novega znanja s predznanjem dijakov. Analiza pa tudi pokaže, da učiteljeve spodbude $\mathrm{k}$ bralnim aktivnostim nimajo tako velikega učinka na bralno pismenost $\mathrm{v}$ skandinavskih državah, kot je to ugotovljeno za Slovenijo. Zanimivo je, da skandinavski I 5 -letniki kljub zaznani slabši podpori s strani učitelja (tako v primerjavi s povprečjem OECD kot Slovenijo) dosegajo vrhunske bralne rezultate. Po drugi strani pa slovenski dijaki v povprečju zaznavajo manj pozitiven odnos učiteljev do njih, kot je to ugotovljeno na Finskem in Norveškem (vendar so tudi rezultati za Norveško podpovprečni). Omenjen odnos učite- 
ljev do dijakov tudi ni pomemben napovednik bralnih dosežkov slovenskih dijakov, medtem ko ima pomemben učinek na bralne dosežke v primerjanih skandinavskih državah. Na sploh pa lahko sklepamo, da so didaktični vidiki pouka materinščine v Sloveniji mnogo bolj ugodno zaznani s strani učencev in dijakov, kot to velja za Finsko in Norveško.

\section{Bralni profili slovenskih dijakov}

Slovenske dijake v vzorcu raziskave PISA 2009 smo v nadaljevanju raziskave združili v skupine po podobnosti glede na to, kakšne lastnosti opredeljujejo njihovo branje (uporaba metakognitivnih in učnih strategij, motivacija za branje, raznolikost bralnega gradiva, branje na spletu, interpretacija literarnih tekstov). Z dvostopenjsko klastrsko analizo smo dijake uvrstili v pet klastrov glede na značilnosti njihove bralne motivacije ter učnih in metakognitivnih strategij pri branju besedil:

I. Nezavzeti bralci s slabimi učnimi in metakognitivnimi strategijami (I 4,7 \%)

2. Nezavzeti bralci z dobrimi učnimi in slabimi metakognitivnimi strategijami, spletni bralci (1 4,6 \%)

3. Nezavzeti bralci s povprečnimi učnimi in metakognitivnimi strategijami $(28,7 \%)$

4. Zavzeti in globinski bralci (20\%)

5. Zavzeti bralci s povprečnimi učnimi in metakognitivnimi strategijami (22,I $\%)$.

Profila 4 in 5 sta bralno kompetentna profila. Na reprezentativnem vzorcu slovenskih Is-letnikov torej labko sklepamo, da je v Sloveniji približno $40 \%$ takih dijakov, ki so zavzeti bralci ter imajo dobro razvite učne in metakognitivne strategije. Kar tri skupine mladih bralcev (okoli $60 \%$ ) pa opredeljuje nezavzeto branje, kar še enkrat potrjuje že omenjeno dejstvo, da so slovenski dijaki v povprečju nizko motivirani bralci. Med nizko motiviranimi bralci sta dve skupini dijakov ( $\mathrm{I}$ in 2 ; okoli $30 \%$ ), za kateri so značilne slabo razvite metakognitivne strategije, ki so se izkazale kot pomemben napovednik bralne pismenosti. Iz rezultatov lahko sklepamo, da je zavedanje učinkovitih metakognitivnih strategij tisti dejavnik, ki ločuje slabše in bolj uspešne bralce. Če ima posameznik sicer precej dobro razvite učne strategije (med katerimi pa prevladujejo strategije memoriranja), vendar nima ustrezno razvitega zavedanja uporabnosti bralnih strategij pri različnih bralnih nalogah (metakognitivni vidik), hkrati pa je nezavzet bralec, obstaja precejšnja verjetnost, da je njegova bralna pismenost slaba. 
Ugotavljali smo tudi razlike med petimi skupinami dijakov v bralnih dosežkih z vidika bralnega procesa. Pri vseh treh vidikih bralne pismenosti z vidika bralnega procesa je opaziti podoben trend: najbolj kakovostni bralni procesi so prisotni v skupini zavzetih in globinskih bralcev. Na drugem mestu se nahaja skupina zavzetih bralcev, ki imajo povprečno razvite učne in metakognitivne strategije. Pri obeh omenjenih skupinah dosežki na področjih bralne pismenosti presegajo mejo 500 točk (povprečen dosežek slovenskih I5-letnikov v raziskavi PISA 2009 je 483 točk). Naslednja skupina po uspešnosti bralnih procesov je skupina nezavzetih bralcev s povprečnimi učnimi in metakognitivnimi strategijami. Skupini, v katerih je prisotna najslabša kakovost bralne pismenosti z vidika bralnega procesa, sta skupini nezavzetih bralcev (s slabimi učnimi in metakognitivnimi strategijami - skupina I - in z dobrimi učnimi in slabimi metakognitivnimi strategijami, spletni bralci - skupina 2). To sta tudi skupini, pri katerih so bralni dosežki še najbolj podobni. Za skupini 4 in 5 je značilno tudi pogostejše interpretiranje bralnih tekstov, hkrati pa se v teh skupinah nahajajo povprečni spletni bralci (branje na spletu je nadpovprečno značilno za skupino 2).

\section{Bralni profili, izobraževalni program in spol}

$\mathrm{V}$ zadnjem delu evalvacijske študije smo proučevali motivacijske, socialne in učne spremenljivke v različnih izobraževalnih programih, zanimale so nas tudi razlike v omenjenih spremenljivkah po spolu. Prav tako so nas zanimali deleži vseh dijakov po izobraževalnih programih ter deleži dijakov in dijakinj, ki se s svojimi specifičnimi značilnostmi motivacije za branje in strategijami branja uvrščajo v pet skupin bralcev. Na koncu smo preverili, ali se skupine bralcev po izobraževalnih programih in po spolu razlikujejo v bralnih dosežkih.

V začetnih analizah tega dela evalvacijske študije smo najprej preverili povprečne ravni bralnih dosežkov po izobraževalnih programih in po spolu. Bralni dosežki, tako skupni dosežek kot dosežki glede na vrsto bralne pismenosti ter zveznost besedila, pričakovano upadajo z nižanjem zahtevnostne ravni izobraževalnega programa. V povprečju dijaki splošnih gimnazij dosegajo četrto raven dosežkov, dijaki strokovnih gimnazij tretjo raven, dijaki strokovnega srednjega izobraževanja v povprečju dosegajo raven temeljnih kompetenc (druga raven). Dijaki srednjega poklicnega izobraževanja v povprečju ne dosegajo temeljne ravni bralne pismenosti. Kot ugotavljata že avtorici študije o doseganju temeljnih in najvišjih ravni pismenosti v raziskavi PISA 2009 glede na srednješolski izobraževalni program (Štraus in Markelj, 20II), je najšibkejše področje pismenosti slovenskih dijakov in dijakinj I. letnikov prav področje bralne pismenosti. Na temeljni ravni namreč to vrsto 
pismenosti dosega manj dijakov I. letnikov $(74,6 \%)$ kot pri matematiki $(76,1 \%)$ in naravoslovju (8I,6 \%). Problematično je dejstvo, da kar 74,4 \% dijakov r. letnikov srednjih poklicnih šol ne dosega temeljne ravni bralne pismenosti. Prav tako pa je med vsemi tremi vrstami pismenosti najnižji odstotek dijakov, ki dosegajo najvišje ravni pismenosti (5. in 6. raven), prav na področju bralne pismenosti. Primerjalne analize podatkov PISA 2006 in PISA 2009 so pokazale, da bralna pismenost med slovenskimi is-letniki upada, in sicer bolj kot npr. pri naravoslovju (povprečni dosežek pri bralni pismenosti v obdobju 20062009 je nižji za I I točk, pri naravoslovju za 7 točk) (Pedagoški inštitut, 20IO). Omenjeni rezultati zahtevajo razlago, zakaj je prav bralna pismenost, ki je podlaga za vse druge vrste pismenosti, tista, ki se - primerjalno z drugimi vrstami pismenosti - kaže kot pomanjkljiva v slovenskem izobraževanju. Zaradi deskriptivne narave metodologije v raziskavi PISA ne moremo podati natančnih vzrokov za omenjene rezultate, lahko pa opišemo nekatere individualne značilnosti dijakov in njihovega socialnega okolja, ki verjetno prispevajo k omenjenim rezultatom. Omenjene značilnosti dijakov, ki so bile že predstavljene v prejšnjih delih evalvacijske študije, tokrat predstavljamo $z$ vidika razlik po izobraževalnih programih in po spolu.

Med individualnimi spremenljivkami, ki lahko vplivajo na bralne dosežke, smo najprej ugotavljali, ali se dijaki različnih izobraževalnih programov razlikujejo v uporabi metakognitivnih in učnih strategij. Učne strategije in njihova učinkovita uporaba so pomemben del učnega procesa, ki so skupaj z drugimi kognitivnimi (npr. védenje in prepričanje o učenju, pojmovanja učenja), metakognitivnimi, motivacijskimi in čustvenimi procesi ter interakcijo med njimi pogoj za razvoj t.vi. učne samoregulacije pri posamezniku, kar pa med drugim vodi tudi v doseganje višjih učnih dosežkov na različnih testih znanja. Tudi v prejšnjih delih evalvacijske študije smo z dvonivojskimi linearnimi modeli ugotavljali, da ob nadzoru ostalih individualnih in socialnih spremenljivk in izobraževalnega programa metakognitivne strategije ter kontrolne učne strategije pojasnjujejo pomemben delež variabilnosti v bralnem dosežku. $V$ tem delu evalvacijske študije se je pokazalo, da so bralne metakognitivne strategije najbolj prisotne pri dijakih splošnih gimnazij, prisotnost teh strategij pa potem upada z nižanjem ravni zahtevnosti programov. Podobno ugotavljamo za uporabo kontrolnih učnih strategij. Zaznavanje uporabnosti učinkovitih strategij povzemanja besedila ter razumevanja in pomnjenja besedila ter dejansko ugotavljanje razumevanja bistvenih delov besedila, ko se dijak sooči s konkretnim besedilom, so torej najbolj prisotni v izobraževalnem programu, v katerem dijaki izkazujejo tudi najvišjo stopnjo bralne pismenosti. Ti se nahajajo tudi nad povprečjem OECD v oceni koristnosti uporabe meta- 
kognitivnih strategij. Nadalje slovenski dijaki različnih izobraževalnih programov (razen srednjega poklicnega programa), primerjalno s povprečjem OECD, v kar precejšnji meri uporabljajo tudi kontrolne strategije. Strategije memoriranja kot manj zahtevne učne strategije, ki se pokažejo tudi kot negativno povezane z bralnimi dosežki, pa prevladujejo v srednjem strokovnem in poklicnem izobraževanju. Pri manj uspešnih bralcih je zato pomembno ozavešcati pomembnost različnih učnih in metakognitivnih strategij, ki labko povečajo kakovost učenja: nadzor nad razumevanjem prebranega, ugotavljanje bistvenega $v$ besedilu, privzemanje ucinkovitih strategij ponavljanja (ne le zapomnitev prebranega na pamet!) ipd. Pri tem ni toliko pomembno, kako pogosto posameznik dejansko uporablja neko učno strategijo, ko bere besedilo (uporaba strategij je odvisna od konteksta, zahtevnosti besedila, posameznikovih kognitivnih sposobnosti ter spoznavnega in učnega sloga), ampak je pomembna ozaveščenost, da so določene strategije lahko učinkovite (tj. da se posameznik zaveda, katere so učinkovite strategije povzemanja, razumevanja in pomnjenja besedila) in da jih je posameznik pripravljen dejansko tudi uporabiti takrat, ko je to potrebno, da poveča svojo zmožnost in učinkovitost kompetentnega branja.

$\mathrm{V}$ nadaljevanju nas je zanimalo, v kolikšni meri dijaki različnih izobraževalnih programov opravljajo bralne dejavnosti v učne namene. $\mathrm{V}$ prejšnjih analizah raziskave PISA 2009 se je pokazalo, da je zlasti pogostost interpretacije bralnih besedil tista, ki ob nadzoru drugih dejavnikov pomembno pojasnjuje bralne dosežke slovenskih dijakov. Interpretacija literarnih besedil je podobno prisotna pri dijakih obeh vrst gimnazij (pri obeh skupinah je ta nad povprečjem OECD), najmanj pa je prisotna v srednjem poklicnem izobraževanju. Branje literarnih del, razlage vzrokov v besedilu, namena besedila ipd. so torej pomembni dejavniki bralne pismenosti, ki jih je potrebno dodatno okrepiti v strokovnih in poklicnih šolah.

$\mathrm{V}$ srednjem strokovnem in poklicnem izobraževanju prevladuje uporaba gradiv za funkcionalno branje, kar se zdi smiselno glede na naravo strokovnega in poklicnega izobraževanja in pridobivanja poklicnih kompetenc. Vendar je za splošno raven bralne pismenosti pomembno tudi branje zahtevnejših besedil ter obravnavanje omenjenih (literarnih) besedil pri pouku tudi z vidika njihovih interpretacij, saj te navajajo na smisel prebranega in smiselnost branja nasploh.

Motivacija za branje je v zadnjih dveh desetletjih pogost predmet proučevanja strokovnjakov z različnih področij, še posebej bralne pismenosti. Ob bralni motivaciji pa se v strokovni literaturi pogosto pojavlja tudi pojem bralna zavzetost oz. angažiranost. Tudi v raziskavi PISA 2009 govorimo v okviru bralne motivacije o t. i. bralni zavzetosti. Zavzet 
bralec je znotraj omenjenega koncepta tisti, ki je notranje motiviran, tj. tisti, ki bere, ker ga branje privlači in ga tudi pozitivno vrednoti. Tak bralec nosi v sebi prepričanja, cilje in vrednote, zaradi katerih se udejstvuje v različnih bralnih aktivnostih in uspešno dosega zastavljene izobraževalne, poklicne, osebne ter socialne cilje.

Bralna zavzetost znotraj koncepta raziskave PISA vključuje interes za branje, avtonomijo pri branju in socialno interakcijo ter pogostost in raznovrstnost branja. Zavzetega bralca v tem pogledu opredeljuje dobro izoblikovan interes za branje, raznovrstne teme branja in tipi bralnega gradiva (interes za branje), zavzeti bralci berejo samoiniciativno in nadzorujejo svoj proces branja (avtonomnost), s pomočjo socialnega okolja širijo svoje bralne kompetence in delijo svoje znanje in izkušnje $\mathrm{z}$ drugimi (socialni vidik) ter berejo pogosto in posegajo po raznovrstnih besedilih (bralno vedenje). V prejšnjih delih evalvacijske študije smo ugotovili, da sta uživanje v branju in raznolikost bralnega gradiva tista motivacijska dejavnika, ki pozitivno napovedujeta bralne dosežke (ob nadzoru ostalih individualnih in socialnih napovednikov ter vrste šole). Uživanje v branju je nadpovprečno prisotno pri dijakih splošnih gimnazij (glede na povprečje OECD), raznolikost gradiva, ki ga dijaki berejo, pa je nad povprečjem OECD pri dijakih obeh vrst gimnazij. Motivacijski vidiki bralne pismenosti so v največji meri prisotni pri dijakih splošnih gimnazij, nato pa bralna motivacija upada z nižanjem zahtevnostne ravni izobraževalnih programov. Dijaki različnih izobraževalnih programov se torej razlikujejo v bralni zavzetosti, kar je povezano tudi z razlikami v njihovih bralnih dosežkih.

Mnogo avtorjev opozarja tudi na pomembnost socialnega okolja pri razvoju motivacije za branje, kamor uvrščajo odnose s sovrstniki, starši in učitelji (Guthrie in Wigfield, 2000; McCombs in Barton, 1998; Meltzer in Hamann, 2004). Ta vidik bralne pismenosti je poudarjen tudi znotraj raziskave PISA. Pomembno vlogo pri oblikovanju lastnega odločanja za branje ima tudi šola, učitelji s svojim načinom poučevanja ter šolska in razredna klima. V raziskavi so bili pridobljeni nekateri podatki o pouku slovenščine, kot so zaznane učiteljeve spodbude $\mathrm{k}$ branju in disciplina $\mathrm{v}$ razredu, prav tako so udeleženci podali tudi svoje stališče o šoli. Spodbude k branju s strani učitelja slovenščine so v največji meri zaznavali dijaki splošnih in strokovnih gimnazij. Vendar pa, glede na povprečje OECD, dijaki vseh štirih izobraževalnih programov nadpovprěno ocenjujejo učiteljeve spodbude k branju. $\mathrm{V}$ slovenskih šolah učitelji slovenščine torej v precejšnji meri spodbujajo dijake $\mathrm{k}$ branju, kar je ugodno, saj so spodbude k branju s strani učitelja tudi pomemben napovednik bralne pismenosti. Četudi je kakovost poučevanja s strani dijakov zaznana precej pozitivno, pa je dejstvo, da so razlike v bralnih dosežkih po izobraževalnih programih precejšnje. Po- 
membno je dejstvo, da je disciplina v razredu najslabše zaznana strani dijakov srednjega poklicnega izobraževanja (podpovprečno tudi glede na povprečje OECD), kar labko pomembno negativno interferira $z$ uciteljevimi prizadevanji po kakovostnem pouku. Na drugi strani pa je zaskrbljujoče, da dijaki splošnih in strokovnih gimnazij izražajo dokaj negativna stališča do šole kot ustanove, ki bi jih ustrezno pripravila na odraslo življenje, naučila stvari, ki so koristne pri opravljanju poklica, ter jim pomagala pri razvijanju samozavesti. V srednjih strokovnih in poklicnih šolah bi tako bilo dobro še v večji meri usmeriti pozornost na disciplino v razredu ter učitelje opremiti z možnimi načini uravnavanja vedenja v razredu. $\mathrm{V}$ gimnazijah pa bi bilo treba $\mathrm{v}$ večji meri poudariti koristnost in uporabnost omenjenih izobraževalnih programov za posameznikovo kasnejše akademsko in poklicno življenje.

Dijaki različnih izobraževalnih programov poročajo o podpovprečni dostopnosti IKT v šoli, dostopnost IKT doma pa je primerljiva s povprečjem OECD. Dijaki splošnih gimnazij uporabljajo računalnik v šoli pod povprečjem, dijaki poklicnih šol pa so v uporabi računalnika $v$ šoli nad povprečjem. Za potrebe šolskega učenja uporabljajo računalnik doma v največji meri dijaki strokovnih gimnazij. Zanimivo je, da je spletno branje nadpovprečno prisotno $\mathrm{v}$ vseh izobraževalnih programih razen $\mathrm{v}$ poklicnem izobraževanju. Pri tem so najpogostejši spletni bralci dijaki obeh vrst gimnazij. Spletno branje v veliki meri služi za zabavo, saj so slovenski dijaki (gimnazijci) v nadpovprečju glede uporabe IKT in interneta za zabavo. Dijaki se v vseh izobraževalnih programih ocenjujejo kot visoko učinkoviti pri opravljanju IKT nalog visoke ravni ter imajo nadpovprečno pozitivna stališča do dela $\mathrm{z}$ računalnikom (zlasti dijaki strokovnih gimnazij in srednjega strokovnega izobraževanja). Zaključimo lahko, da se slovenski dijaki I. letnikov v vseh izobraževalnih programih $v$ precejšnji meri ukvarjajo $z$ aktivnostmi, povezanimi $z$ računalnikom in spletom, ter da so za te dejavnosti notranje motivirani ter izražajo precejšnjo mero kompetentnosti pri delu $z I K T$. Vendar je spletno branje v veliki meri povezano z zabavo (spletne igre, klepetalnice, socialna omrežja ipd). Zato je potreben razmislek, kako angažiranost dijakov pri delu $\mathrm{z}$ računalnikom uporabiti tudi v učne namene. Skladno s tem je potrebno zagotoviti tudi večjo dostopnost IKT v šoli.

Glede na značilnosti bralne motivacije ter učnih in metakognitivnih strategij pri branju besedil lahko ugotovimo, da so zavzeti in globinski bralci predvsem dijaki splošne gimnazije. V programih strokovna gimnazija in strokovno srednje izobraževanje prevladujejo nezavzeti bralci s povprećnimi ućnimi in metakognitivnimi strategijami, $v$ srednjem poklicnem izobraževanju pa prevladujejo nezavzeti bralci s slabimi učnimi in metakognitivnimi strategijami. Zdi se, da je pri dijakih, ki ne prihajajo s splošnih gimnazij, problem prav v 
njihovi bralni nezavzetosti. Bralna nezavzetost se v strokovnih gimnazijah ter strokovnem srednjem izobraževanju kaže kot mnogo večji problem kot sama uporaba učnih in metakognitivnih strategij pri branju. Slednje so (skupaj z bralno nezavzetostjo) predvsem problematične v programih poklicnega izobraževanja.

Spol se kaže kot pomemben dejavnik bralne pismenosti, kar smo ugotovili tako v naši evalvacijski študiji, kot so ugotovili tudi drugi raziskovalci v primarnih analizah podatkov PISA 2009 (OECD, $2010 a)$. V Sloveniji so I5-letnice dosegle 55 točk več na testu bralne pismenosti kot njihovi moški vrstniki, kar predstavlja več kot polovico ene ravni branja (Pedagoški inštitut, 20Io). V tem delu evalvacijske študije smo zato preverili, ali obstajajo razlike med fanti in dekleti $v$ dejavnikih bralne pismenosti, kot so bralna motivacija, učne in metakognitivne strategije, pogostost branja za šolo, percepcija pouka slovenščine in stališča do šole, uporaba IKT v šoli in doma, ter v spremenljivkah družinskega okolja, kot so izobrazbena raven staršev ter materialne, kulturne in izobraževalne dobrine doma. Rezultati kažejo, da imajo dekleta višjo motivacijo za branje, v večji meri uporabljajo metakognitivne strategije, kontrolne strategije in memoriranje, ugodneje zaznavajo učiteljeve spodbude $\mathrm{k}$ branju, več obiskujejo knjižnico ter se ukvarjajo $\mathrm{z}$ branjem in interpretiranjem literarnih besedil. Na drugi strani se kažejo kot manj pogoste spletne bralke, manj uporabljajo IKT doma in $\mathrm{v}$ šoli, manj uporabljajo IKT v namene zabave ter se zaznavajo tudi kot manj kompetentne za uporabo IKT v zahtevnejše namene kot fantje. Zanimivo je, da poročajo o nižjem socialno-ekonomskem položaju svojih družin ter o manj kulturnih in materialnih dobrinah svoje družine kot fantje. Tudi računalnik v šoli in doma dekleta $\mathrm{v}$ manjši meri uporabljajo $\mathrm{v}$ učne namene ter imajo manj pozitivna stališča do računalnikov kot fantje. Približno $60 \%$ deklet sodi v skupini zavzetih bralk (klastra 4 in 5), medtem ko se $v$ teh skupinah nahaja petina fantov. Iz rezultatov bi labko sklepali, da so pomembna močna področja deklet, ki prispevajo $k$ njihovi boljsi bralni pismenosti, večja bralna angažiranost, pogostost branja literarnib besedil in besedil v tiskani obliki, pogostost interpretacije bralnih tekstov, prav tako je pomembno, da pozitivno zaznavajo spodbude učitelja k branju. Pri fantih se zdi problematično prav področje bralne motivacije, saj v mnogo manjši meri uživajo v branju kot dekleta (rezultat je podpovprečen tudi v primerjavi z vrednostjo povprečnega rezultata OECD), prav tako podpovprečno zaznavajo uporabnost metakognitivnih strategij pri branju. Po drugi strani pa je labko primerjalna prednost fantov pri spodbujanju bralne pismenosti njihova motiviranost in zaznana kompetentnost pri delu z IKT. V primerjavi $\mathrm{z}$ dekleti več berejo na spletu in več uporabljajo IKT ter internet (vendar predvsem v namene zabave!). Omenjen dejavnik bi zato veljalo pri fantih spodbujati še v večji meri, seve- 
da v smeri povečanja uporabe IKT za namen učenja. Povezovanje učenja z uporabo IKT pri pouku in doma bi tako verjetno ugodno učinkovalo na poskus povečanja motivacije za branje pri fantih.

\section{Literatura}

Baker, L. in Wigfield, A. (1999). Dimensions of children's motivation for reading and their relations to reading activity and reading achievement. Reading Research Quarterly, 34, 452-477.

Boekaerts, M. (2009). Goal-directed behaviors in the classroom. V K.R. Wentzel in A. Wigfield (ur.), Handbook of motivation at school (str. 105-122). New York: Routledge.

Cohen, J. (1988). Statistical power analysis for the behavioral sciences, Second Edition. Hillsdale, NJ: Lawrence Erlbaum Associates.

Cunningham, A. E. in Stanovic, K. E. (1991). Tracking the unique effects of print exposure in children: Associations with vocabulary, general knowledge, and spelling. Journal of Educational Psychology, 83, 264-274.

Čad, S. (2011). Šola v naravi pri nas in na Norveškem. Diplomsko delo. Univerza v Ljubljani: Fakulteta za šport.

Entwistle, N. J. in Ramsden, P. (1983). Understanding student learning. London: Croom Helm.

Eurydice Slovenija (2009). Norveška: Bela knjiga o začetnem izobraževanju osnovnošolskih učiteljev. Dostopno na spletni strani: http://wwhw.regjeringen.no/en/dep/kd/ Documents/Brochures-and-handbooks/2009

Flavell, J. H. (1979). Metacognition and cognitive monitoring. A new area of cognitive-developmental inquiry. American Psychologist, 34, 906-911.

Goldman, S.R. in Rakestraw, J.A. (2000). Structural aspects of constructing meaning from text. V M. L. Kamil, P. B. Mosenthal, P. D. Pearson in R. Barr (ur.), Handbook of reading research (str. 311-336). Mahwah, NJ: Erlbaum.

Guthrie, J. T. in Alao, S. (1997). Engagement in reading for young adolescents. Journal of Adolescent and Adult Literacy, 40, 438-446.

Guthrie, J. T. in Wigfield, A. (2000). Engagement and motivation in reading. V M.

L. Kamil, P. B. Mosenthal, P. D. Pearson in R. Barr (ur.), Handbook of reading research (str. 403-422). Mahwah, NJ: Lawrence Erlbaum.

Irvin, J. L. in Mullins, E. R. (2000). Transition into middle school. Middle School Journal, 31, 57-60. 
Kjaernsli, M. in Roe, A. (2011). On the right track: Norwegian student's proficiency in Reading, Mathematics and Science Literacy in the PISA assessment 2009. Dostopno na spletni strani: http://www.pisa.no/pdf/publikasjoner/Short_version_in_English_ PISA2009_Norway.pdf

Lewis, J. (1996). Academy literacy: Reading and strategies. Lexington, Toronto: D. C. Health and Company.

Lončarič, D. in Peklaj, C. (2008). Proaktivna in defenzivna samoregulacija pri učenju. Psibološka obzorja, 17, 73-88.

Marentič Požarnik, B. (2000). Psihologija učenja in pouka. Ljubljana: DZS.

Marjanovič Umek, L., Sočan, G. in Bajc, K. (2006). Psihološki in družinski dejavniki šolske ocene. Sodobna pedagogika, 57 (2), 108-129.

McCombs, B. L. in Barton, M. L. (1998). Motivating secondary school students to read their tex tbooks. NASSP Bulletin, 82, 24-33.

Meltzer, J. in Hamann, E. T. (2004). Meeting the literacy development needs of adolescent english language learners through content area learning. Part one: Focus on motivation and engagement. Providence: Brown University.

Murdock, T. B. in Anderman, L. H. (2000). Middle-grade predictors of student's motivation and behavior in high school. Journal of Adolescent Research, 15, 327-350.

OECD (2009). PISA 2009 Assessment framework: Key competencies in reading, mathematics and science. Paris: OECD.

OECD (2010a). PISA 2009 Results: What students know and can do - Student performance in reading, mathematics and science (Volume I). Dostopno na spletni strani:http://dx.doi.org/10.1787/9789264091450-en

OECD (2010b). PISA 2009 Results: Overcoming social background - Equity in learning opportunities and outcomes (Volume II). Dostopno na spletni strani: http://dx.doi. org/10.1787/9789264091504-en

OECD (2010c). PISA 2009 Results: Learning to learn - Student engagement, strategies and practices (Volume III). Dostopno na spletni strani: http://dx.doi. org/10.1787/9789264083943-en

OECD (2010̌̌). PISA 2009 Results: What makes a school successful? - Resources, policies and practices (Volume IV). Dostopno na spletni strani: http://dx.doi. org/10.1787/9789264091559-en

OECD (2010d). Finland: Slow and steady reform for consistently high results. Dostopno na spletni strani: http://www.oecd.org/pisa/pisaproducts/46581035.pdf 
Pečjak, S. in Gradišar, A. (2002). Bralne učne strategije. Ljubljana: Zavod Republike Slovenije za šolstvo.

Pečjak, S., Bucik, N., Gradišar, A. in Peklaj, C. (2006). Bralna motivacija v šoli: merjenje in razvijanje. Ljubljana: Zavod Republike Slovenije za šolstvo.

Pečjak, S. (2010). Psihološki vidiki bralne pismenosti. Ljubljana: Znanstvena založba Filozofske fakultete.

Pedagoški inštitut (2010). OECD PISA 2009. Prvi rezultati. Ljubljana: Pedagoški inštitut.

Pintrich, P. R. in De Groot, E. V. (1990). Motivational and self-regulated learning components of classroom academic performance. Journal of Educational Psychology, 82, 33-40.

Pintrich, P.R. in Schrauben, B. (1992). Students' motivational beliefs and their cognitive engagement in classroom academic tasks. V D.H. Schunk in J.L. Meese (ur.), Student perceptions in the classroom (str. 149-184). Hillsdale, NJ: Erlbaum.

Puklek Levpušček, M., Podlesek, A. in Šterman Ivančič, K. (2012). Dejavniki bralne pismenosti v raziskavi PISA 2009 (Digitalna knjižnica, Dissertationes, 21). Ljubljana: Pedagoški inštitut.

Puklek Levpušček, M. in Zupančič, M. (2009). Osebnostni, motivacijski in socialni dejavniki učne uspešnosti. Ljubljana: Znanstvena založba Filozofske fakultete.

Raudenbush, S. W., Bryk, A. S., Cheong, Y. F. in Congdon, R (2005). Hierarchical linear and nonlinear modeling, Version 6.02: Users' Guide and Software Program. Chicago: Scientific Software International.

Regner, I., Loose, F. in Dumas, F. (2009). Students' perceptions of parental and teacher academic involvement: Consequences on achievement goals. European Journal of Psychology of Education, 24, 263-277.

Schiefele, U. (2009). Situational and individual interest. V K.R. Wentzel in A. Wigfield (ur.), Handbook of motivation in school (str. 197-223). New York: Taylor Francis.

Štraus, M. in Markelj, N. (2011). Bralna, matematična in naravoslovna pismenost dijakinj in dijakov 1. letnikov srednjih šol v Sloveniji v raziskavi PISA 2009. Šolsko polje, $22(5-6), 36-68$.

Weinstein, C. E. in Hume, L. M. (1998). Study strategies for lifelong learning. Washington, DC: APA.

Wigfield, A. in Guthrie, J. T. (1997). Relations of children's motivation for reading to the amount and breadth of their reading. Journal of Educational Psychology, 89, $420-432$. 
Zimmerman, B.J. in Cleary, T.J. (2009). Motives to self-regulate learning: A social cognitive account. V K.R. Wentzel in A. Wigfield (ur.), Handbook of motivation in school (str. 1247-1264). New York: Taylor Francis. 


\title{
Povezanost med motivacijo za izobraževanje, tekmovalnostjo in različnimi področji samopodobe pri študentih
}

\author{
Darja Kobal Grum,' Janez Kolenct² in Manca Seničar
}

\section{Notranji in zunanji motivacijski viri}

Motivacija je proces, ki spodbuja in usmerja vedenje posameznika k določenemu cilju (Pintrich in Schunk, 1996). Motivacije ni mogoče opazovati neposredno, temveč lahko o njej sklepamo le prek vedenja posameznika: napora, ki ga vloži v neko dejavnost, nalog, ki jih opravlja, in prek tistega, kar nam o lastni motivaciji pove sam. Pintrich in Schunk (1996) menita, da sta za razumevanje motivacije osrednjega pomena cilj in dejavnost. Cilj je lahko prisoten eksplicitno ali implicitno (McMeniman, 1989). Če je prisoten eksplicitno, se ga posameznik jasno zaveda in ga v skladu z izkušnjami tudi spreminja. Če pa je cilj $\mathrm{v}$ motivacijskem procesu prisoten implicitno, posameznik ne ve prav dobro, kaj hoče s svojim vedenjem doseči. Tudi implicitno prisoten cilj se lahko z izkušnjami spreminja in postane ekspliciten. Obema vrstama cilja pa je skupno zavedanje posameznika, da bi rad nekaj dosegel. Dejavnost, na podlagi katere si posameznik prizadeva doseči zastavljeni cilj, je lahko fizična ali mentalna (Pintrich in Schunk, 1996). Fizična dejavnost vsebuje napor, vztrajnost itd., mentalna dejavnost pa zajema kognitivna dejanja, kot so načrtovanje, predelava in organiziranje informacij, odločanje, reševanje problemov itd.

Motivacija ima v mladostništvu zelo veliko vlogo predvsem v okviru učenja in izobraževanja, saj skrb za šolo in učno uspešnost že v zgodnjem mladostništvu postaja pomemben dejavnik pri načrtovanju mladostnikovega nadaljnjega izobraževanja, ki začrta tudi njegovo kasnejšo poklicno kariero (Anderman in Maehr, 1994). Raziskave kažejo, da se z vstopom v mladostništvo občutno zmanjšajo trije pomembni dejavniki učne uspešnosti: stališča do šole, samopodoba, ki se nanaša na sposobnosti, in motivacija učencev

I Univerza v Ljubljani, Filozofska fakulteta, Oddelek za psihologijo

2 Pedagoški inštitut v Ljubljani 
(Epstein in McPartland, 1976; Harter, 1981; Marsh, Owens, Myers in Smith, 1989). Anderman in Maehr (1994) predpostavljata tri možne individualne vzroke upada motivacije v mladostništvu: (i) razvojne spremembe, (ii) spremembe v samopodobi, ki deluje kot motivator, in (iii) prehodi med notranjo in zunanjo motivacijo; z njimi pa se prepletajo tudi spremembe $\mathrm{v}$ ožjem in širšem socialnem okolju, v katerem živi mladostnik. Vsem trem individualnim dejavnikom je skupna spoznavna osnova. Avtorja namreč menita, da je mogoče s proučevanjem motivacije v kontekstu razvoja spoznavnih procesov natančneje ugotoviti vzroke upada motivacije v mladostništvu. Razvojne spremembe v spoznavnih procesih omogočajo spremenjeno razumevanje pojmov, kot so sposobnosti, kompetentnost in inteligentnost. Avtorja ugotavljata, da na prehodu iz otroštva v mladostništvo otroci začnejo dojemati omenjene značilnosti kot nekaj danega in trajnega. Ob takšnem neustreznem razumevanju sposobnosti in inteligentnosti tudi kasneje niso več tako motivirani za učenje, saj z neuspehom kljub učenju tvegajo upad lastnega samospoštovanja in upad spoštovanja s strani drugih. To pomeni, da samospoštovanje in samopodoba delujeta kot motivator za mladostnikovo ravnanje in obratno. Ustrezna motivacija za učenje omogoča tudi razvoj pozitivne in stabilne samopodobe.

Seveda pa je potrebno upoštevati, da obstaja več vrst motivacije za učenje, ki jih v literaturi običajno zasledimo pod oznakama notranja in zunanja motivacija. Notranja ali intrinzična motivacija je povezana z željo po učenju. McMenniman (1989: 216) jo imenuje »želja po učenju zaradi želje same.« Berlyne (1966, po McMenniman, 1989) je menil, da je notranja motivacija povezana s prirojeno radovednostjo v zvezi z neznanim. Novejše raziskave (Harter, 198I) pa kažejo, da prirojena radovednost z odraščanjem upada, posledično s tem pa tudi notranja motivacija. McMenniman (1989) poudarja, da notranja motivacija spodbuja konceptualno učenje in vodi k ustvarjalnemu mišljenju. Nasprotno je, kot pove že samo ime, zunanja ali ekstrinzična motivacija (McMenniman, 1989) tista, pri kateri se posameznik uči zaradi zunanjega vzroka. To so lahko ocene, pritisk staršev, nagrada ob koncu šolskega leta itd. McMeniman (1989) meni, da je ta vrsta motivacije značilen pojav v mnogih razredih.

Posebna vrsta motivacije je storilnostna motivacija. McMeniman (1989) meni, da imajo visoko storilnostno motivirani posamezniki močno izraženo potrebo po uspehu. Močno si prizadevajo $\mathrm{k}$ uspehu zaradi uspeha samega, pogosto izbirajo situacije, ki zahtevajo visoko mero osebne odgovornosti za uspeh, pogosto so uspešni v tveganih situacijah, zato so tudi nagnjeni k tveganemu vedenju, kjer je možnost za uspeh le petdesetodstotna. Poleg tega najraje izbirajo naloge, ki niso niti prelahke niti pretežke, in večkrat že vnaprej predvidijo, katere bodo uspešno obvladali. 
Intrinzična in ekstrinzična motivacija sta osrednja pojma teorije samodoločenosti (angl. »self-determination theory«; Deci in Ryan, 1985), ki ločuje med različnimi vrstami motivacije glede na vzroke oziroma cilje, ki spodbudijo določeno dejavnost. Intrinzična motivacija se tako nanaša na izvajanje neke dejavnosti, ker le-ta posameznika zanima ali mu prinaša zadovoljstvo, ekstrinzična motivacija pa pomeni izvajanje aktivnosti, ker le-ta vodi do nekega ločenega izida oziroma rezultata. Intrinzična motivacija obstaja tako znotraj posameznika kot $\mathrm{v}$ odnosu med posameznikom in različnimi aktivnostmi (Ryan in Deci, 2000). Ljudje so za nekatere dejavnosti intrinzično motivirani in za druge ne, prav tako pa niso vsi intrinzično motivirani za kakršno koli specifično aktivnost. Medtem ko nekateri avtorji obravnavajo intrinzično motivacijo kot enoten konstrukt, pa drugi raziskovalci menijo, da lahko znotraj intrinzične motivacije ločimo specifičnejše motive (Deci, 1975). Vallerand, Blais, Briere in Pelletier (1989) so na osnovi tega opredelili tri vidike intrinzične motivacije: motiv po védenju, motiv po dosežkih in motiv po občutenju stimulacije. Motiv po védenju se nanaša na to, da posameznik izvaja določeno aktivnost zaradi užitka in zadovoljstva, ki ga doživlja med učenjem, raziskovanjem ali prizadevanjem, da bi razumel nekaj novega. Študentje so tako motivirani za védenje, kadar berejo literaturo iz čistega užitka, ki ga doživljajo med učenjem novih stvari. Motiv po dosežkih pomeni, da se posameznik vključuje v določene aktivnosti zaradi užitka in zadovoljstva, ki ga doživlja, medtem ko poskuša nekaj doseči ali ustvariti. Bolj kot sam rezultat je torej poudarjen proces. V kontekstu študija se ta motiv izraža na primer v tem, da se študent pri neki nalogi poglobi v delo bolj, kot bi bilo potrebno (prebere več literature, kot je bilo zahtevano ipd.), pri čemer mu to, da poskuša preseči samega sebe, daje zadovoljstvo. Motiv po občutenju stimulacije pa se pokaže, ko se posameznik vključi v določeno aktivnost z namenom doživljanja občutij, kot so senzorni užitki, estetska doživetja, zabava, vznemirjenje itd. Pri študentih se ta motiv pokaže na primer takrat, ko se udeležijo predavanja zaradi vznemirjenja, ki ga doživljajo med diskusijami s kolegi.

Podobno sta Deci in Ryan (1991) opredelila tudi več vrst ekstrinzične motivacije. Ekstrinzična motivacija je sprva veljala za osiromašeno vrsto motivacije, nasprotno intrinzični motivaciji. Teorija samodoločenosti pa zagovarja obstoj različnih vrst ekstrinzične motivacije, kjer nekatere sicer resnično predstavljajo osiromašene oblike motivacije, vendar pa obstajajo tudi takšne, ki se nanašajo na aktivna, dejavna stanja in vsebujejo različne ravni avtonomnosti. Tako si od nižje proti višji ravni samodoločenosti (in avtonomnosti) sledijo zunanja regulacija, introjekcija in identifikacija. Pri zunanji regulaciji posameznik izvaja aktivnost, da bi zadostil zunanjim zahtevam ali pridobil določeno nagrado. Vedenje torej uravnavajo dejavniki, kot so nagrade in kazni. Študent se na primer dan pred izpitom 
uči, ker ga k temu prisilijo starši. Ljudje običajno zaznavajo zunanje regulirano vedenje kot kontrolirano in odtujeno. Zunanja regulacija tako predstavlja tisto vrsto ekstrinzične motivacije, ki je nasprotna intrinzični motivaciji. Introjektirana regulacija je vrsta notranje regulacije, ki je še vedno precej kontrolirana, saj posameznik izvaja aktivnost pod pritiskom in z namenom, da bi se izognil krivdi ali tesnobnosti oziroma da bi občutil ponos. Introjekcija pravzaprav predstavlja regulacijo prek pogojenega samospoštovanja. Posameznik začne ponotranjati razloge za svoja dejanja. Kljub temu ta oblika ponotranjanja ni povsem samodoločena, saj je omejena s preteklimi zunanjimi dejavniki in možnostmi. Študent bi tako rekel, da se dan pred izpitom uči, ker naj bi dobri študentje to počeli. Kadar je vedenje ocenjeno kot pomembno za posameznika in zaznano kot posledica lastne izbire, ponotranjanje zunanjih motivov uravnava identifikacija. Študent bi v tem primeru rekel, da se je dan pred izpitom odločil učiti, ker je to pomembno zanj. Najbolj avtonomna oblika ekstrinzične motivacije pa je integrirana regulacija. Integracija se pojavi, ko se identificirana pravila popolnoma asimilirajo v posameznikov jaz. Do tega pride prek samoraziskovanja in usklajevanja novih pravil s posameznikovimi ostalimi vrednotami in potrebami. Bolj kot posameznik ponotranji razloge za neko aktivnost in jih vključi v svoj jaz, bolj samodoločene postajajo njegove ekstrinzično motivirane dejavnosti. Integrirane oblike motivacije so zelo podobne intrinzični motivaciji, vendar pa so še vedno ekstrinzične, saj je dejavnost, motivirana z integrirano regulacijo, izvedena zaradi njene predvidene instrumentalne vrednosti in $z$ upoštevanjem nekega od vedenja ločenega cilja, kljub temu da je posledica lastne volje in visoko vrednotena v okviru jaza. Proces ponotranjanja je razvojno zelo pomemben, saj posameznik ponotranja vrednote in pravila skozi celotno življenje. Vendar pa teorija samodoločenosti ne obravnava procesa ponotranjanja kot razvojnega procesa, saj posamezniku ni potrebno napredovati po posameznih stopnjah ponotranjanja, ampak lahko usvoji novo obliko vedenjske regulacije na kateri koli točki kontinuuma v odvisnosti od preteklih izkušenj in situacijskih dejavnikov. Ryan in Connell (1989) sta ugotovila, da se vse vrste ekstrinzične motivacije močno povezujejo $s$ stališči in prilagajanjem pri študentih. Bolj kot je bilo vedenje študentov zunanje regulirano, manj zanimanja in truda so pokazali pri učenju, po drugi strani pa je bila pri njih bolj izražena tendenca k pripisovanju krivde za neuspeh drugim, na primer učiteljem. Introjektirana regulacija je bila pozitivno povezana $\mathrm{z}$ vloženim trudom, vendar tudi $\mathrm{z}$ anksioznostjo in manj uspešnim spoprijemanjem z neuspehom. Identificirana regulacija je bila povezana $z$ večjim užitkom pri šolskem delu in pozitivnejšimi načini spoprijemanja s stresom, intrinzična motivacija pa z zanimanjem, zadovoljstvom, občutkom kompetentnosti in pozitivnimi načini spoprijemanja. Kasnejše študije so pokazale, da so avtonomnejše oblike ekstrinzične motivacije povezane 
Z večjo zavzetostjo pri učenju (Connell in Wellborn, 1990), boljšo učinkovitostjo (Miserandino, 1996), manjšim osipom študentov (Vallerand in Bissonette, 1992), kakovostnejšimi učnimi strategijami (Grolnick in Ryan, 1987) in večjim psihičnim blagostanjem (Sheldon in Kasser, 1995). Glede na pomembnost ponotranjanja za posameznikovo doživljanje, vedenje in učinkovitost je nujno spodbujanje av tonomne regulacije ekstrinzično motiviranih aktivnosti (Ryan in Deci, 2000). Ker pa ekstrinzično motivirano vedenje samo po sebi ni zanimivo in ga je potrebno spodbuditi od zunaj, je glavni razlog za to, da posameznik izvaja takšne aktivnosti, da so visoko vrednotene s strani pomembnih drugih, s katerimi se posameznik počuti (ali želi počutiti) povezanega, pa naj bo to družina, vrstniška skupina ali družba. Temelj za spodbujanje ponotranjanja je torej zagotavljanje občutka pripadnosti in povezanosti z osebo, skupino ali kulturo - govorimo torej o temeljni psihični potrebi po povezanosti. V šolskem okolju to pomeni, da študentje ne bodo pripravljeni sprejeti pravil in vrednot, vezanih na šolo, če ne bodo imeli občutka spoštovanja in skrbi s strani učiteljev. Povezanost med motivacijo in temeljnimi psihičnimi potrebami so potrdile številne raziskave. Grolnick in Ryan (1989) sta ugotovila višje ravni ponotranjanja in integracije šolskih vrednot pri otrocih, katerih starši so bolj spodbujali avtonomnost in povezanost. Williams in Deci (1996) sta podobno ugotovila večje ponotranjanje pri študentih, pri katerih so učitelji bolj spodbujali avtonomnost in kompetentnost. Ti izsledki potrjujejo, da spodbujanje povezanosti in kompetentnosti pospešuje proces ponotranjanja, spodbujanje avtonomnosti pa še dodatno povečuje integracijo vedenjskih pravil. Posledično se posameznik pri izvajanju ekstrinzično vrednotenih aktivnosti počuti kompetentnega in povezanega s pomembnimi drugimi, obenem pa ima tudi občutek, da je njegovo vedenje samodoločeno (Ryan in Deci, 2000). Tudi Niemiec in Ryan (2009) menita, da so intrinzične ter avtonomne oblike ekstrinzične motivacije povezane z zavzetostjo za delo in optimalno učenje v šolskem kontekstu. Poleg tega sta ugotovila, da učiteljeva opora študentovim temeljnim potrebam po avtonomnosti, kompetentnosti in povezanosti povečuje študentovo avtonomno samoregulacijo za učenje, akademsko uspešnost in blagostanje. Strategije za spodbujanje av tonomnosti pri študentih vključujejo ponujanje možnosti izbire in tehtnih argumentov za učne aktivnosti, sprejemanje in priznavanje odziva študentov na te aktivnosti ter minimiziranje pritiska in kontrole. Kompetentnost lahko spodbujamo prek optimalnih izzivov in konstruktivnih povratnih informacij, vezanih na učinkovito delo (ne na norme). Povezanost pa lahko spodbujamo z izkazovanjem naklonjenosti, topline in spoštovanja študentom (Niemiec in Ryan, 2009).

Deci in Ryan (2000) opredeljujeta temeljne potrebe kot psihične entitete, ki so nujne za psihološko rast in razvoj, integriteto in blagostanje posameznika. Temeljna psihična 
potreba po avtonomnosti se nanaša na občutek, da je posameznik vzrok svojih akcij in da njegovega vedenja ne uravnavajo zunanje sile oziroma pritiski. Potreba po kompetentnosti se nanaša na občutek sposobnosti in učinkovitosti v lastnih dejanjih, potreba po povezanosti pa na občutek, da ima posameznik stalen, intimen odnos s pomembnimi drugimi. Zadovoljitev teh potreb je po teoriji samodoločenosti nujna za psihično zdravje in posledično povezana $\mathrm{z}$ učinkovitim funkcioniranjem posameznika. Zadovoljujemo jih lahko prek množice vedenj, ki se lahko razlikujejo tako med posamezniki kot tudi med kulturami, kljub temu pa je njihova zadovoljitev ključnega pomena za zdrav razvoj in blagostanje vsakega posameznika, ne glede na to, kateri kulturi pripada. Deci (1975) meni, da je intrinzično motivirano vedenje prototip samodoločene aktivnosti: gre za dejavnosti, ki jih posameznik izvaja spontano, kadar ima občutek, da lahko svobodno sledi svojim interesom. Skladno s teorijo samodoločenosti pa bo posameznik intrinzično motiviran za aktivnost, kadar je le-ta posledica njegove lastne izbire ter kadar se pri njej čuti uspešnega in povezanega s pomembnimi drugimi. Pri tem pa naj bi imeli avtonomnost in kompetentnost nekoliko večjo vlogo kot povezanost (Deci in Ryan, 2000). Ljudje se namreč v določene intrinzično motivirane dejavnosti pogosto vključujejo tudi sami (na primer športi, kot so plezanje, pohodništvo, tek itd.), kar kaže na to, da odnosna opora ni osrednji dejavnik pri ohranjanju intrinzične motivacije.

Poleg intrinzične in ekstrinzične motivacije obstaja še tretji motivacijski konstrukt, ki ga je potrebno upoštevati, če želimo dobro razumeti človekovo vedenje, in sicer amotivacija (Deci in Ryan, 1985). Posameznik je amotiviran, kadar ne zazna povezav med lastnimi dejanji in različnimi izidi; torej ni niti intrinzično niti ekstrinzično motiviran. Želja za vključenost $\mathrm{v}$ določeno aktivnost je odsotna zaradi prenizkega vrednotenje aktivnosti ali občutka, da posamezniku primanjkuje sposobnosti, oziroma zaradi prepričanja, da je aktivnost zanj prezahtevna in da niti zelo velik napor ne bo dovolj za uspeh. Medtem ko tudi najbolj (zunanje) kontrolirane oblike ekstrinzične motivacije vključujejo namen oziroma cilj in motiv, pa amotivacija predstavlja nasprotje tako ekstrinzični kot intrinzični motivaciji, saj je kakršen koli motiv odsoten, z njim pa tudi samodoločenost v odnosu do ciljnega vedenja (Deci in Ryan, 2000). Amotivacija izvira iz nezadovoljenosti temeljnih psihičnih potreb in hkrati povzroča njihovo nadaljnje nezadovoljevanje, zaradi česar je povezana tudi s slabšo učinkovitostjo in slabšim psihičnim zdravjem (Ryan et al., 1995).

Teorija samodoločenosti preučuje tudi socialne in okoljske dejavnike, ki spodbujajo in ohranjajo oziroma zmanjšujejo posamezno vrsto motivacije (Ryan in Deci, 2000). Deci in Ryan (1985) menita, da medosebni odnosi in strukture (nagrade, komunikacija, povratne informacije itd.), ki vodijo k občutkom kompetentnosti med izvajanjem aktivnosti, pove- 
čujejo intrinzično motivacijo za to aktivnost, saj zadovoljujejo temeljno psihično potrebo po kompetentnosti. Deci in Ryan (1985) pa dodajata, da občutek kompetentnosti ne povečuje intrinzične motivacije, če ga ne spremlja tudi občutek avtonomnosti. Če želimo povečati ali ohraniti intrinzično motivacijo, je torej nujno, da se posameznik počuti učinkovitega in hkrati doživlja svoje vedenje kot samodoločeno. Z drugimi besedami, za doseganje visoke ravni intrinzične motivacije mora imeti posameznik zadovoljeni temeljni psihični potrebi po kompetentnosti in avtonomnosti. Veliko študij pa se je poleg teh dveh potreb ukvarjalo tudi z odnosom med avtonomnostjo in kontrolo, pri čemer so avtorji izhajali iz predpostavke, da ekstrinzične nagrade zmanjšujejo intrinzično motivacijo. Metaanaliza (Deci et al., 1999) na tem področju je pokazala, da praktično vsaka vrsta pričakovane, stvarne nagrade, vezane na dobro opravljeno nalogo, zmanjšuje intrinzično motivacijo. Enak učinek imajo tudi grožnje, časovni roki, napotki in tekmovalnost, saj jih ljudje zaznavajo kot nadzornike lastnega vedenja. Nasprotno pa možnost izbire in priložnost za samousmerjanje povečujeta intrinzično motivacijo, saj omogočata večji občutek avtonomnosti. Pomembnost avtonomnosti nasproti kontroli v okviru intrinzične motivacije so avtorji zelo obsežno preučevali tudi v šolskem okolju. Študije so tako pokazale, da učitelji, ki pri učencih podpirajo avtonomnost, na ta način spodbujajo tudi intrinzično motivacijo, radovednost in željo po izzivih (Ryan in Grolnick, 1986). Podobno so tudi otroci staršev, ki spodbujajo avtonomnost, bolj nagnjeni k raziskovanju in izboljšanju lastnih sposobnosti (Grolnick et al., 1997). Ryan in Deci (2000) na osnovi tega zaključujeta, da lahko šolsko in družinsko okolje povečujeta ali zmanjšujeta intrinzično motivacijo prek spodbujanja ali onemogočanja zadovoljitve temeljnih potreb po avtonomnosti in kompetentnosti. Pri tem pa avtorja opozarjata, da se intrinzična motivacija pojavi samo pri aktivnostih, za katere pri posamezniku obstaja notranji interes, torej pri aktivnostih, ki mu predstavljajo izziv ali novost oziroma imajo zanj estetsko vrednost. Pri aktivnostih, ki ga ne privlačijo na tak način, pa ima večji pomen ekstrinzična motivacija. Ryan in Deci (2000) pravita, da večina človekovih dejavnosti ni intrinzično motiviranih. To se pokaže zlasti po obdobju otroštva, ko se možnost za intrinzično motivacijo zmanjša zaradi socialnih zahtev in vlog, ki od posameznika zahtevajo prevzemanje odgovornosti za intrinzično nezanimive naloge. Tako $\mathrm{v}$ šoli intrinzična motivacija upada $\mathrm{z}$ vsakim naslednjim razredom, saj večina šolskih aktivnosti ni zastavljena v smeri spodbujanja intrinzične motivacije. Glavno vprašanje pri tem je, kako motivirati študente, da bodo visoko vrednotili in samoregulirali takšne aktivnosti in jih izvajali samostojno, brez zunanjih pritiskov. Teorija samodoločenosti ta problem obravnava $\mathrm{v}$ okviru ponotranjanja in integracije vrednot ter pravil vedenja (Deci in Ryan, 1985). Ponotranjanje predstavlja proces sprejemanja vrednot in pravil, in- 
tegracija pa se nanaša na preoblikovanje teh pravil v lasten sistem, ki izhaja iz posameznikovega jaza. Če obravnavamo ponotranjanje kot kontinuum, lahko posameznikova motivacija za vedenje sega od amotivacije ali nepripravljenosti za aktivnost prek pasivnega pristanka do aktivne osebne zavezanosti. Naraščajoče ponotranjanje pa omogoča tudi večjo vztrajnost, pozitivnejše samozaznave in kvalitetnejše delo.

\section{Motivacija za učenje in izobraževanje}

$\mathrm{V}$ okviru povezanosti med učenjem in motivacijo za učenje rezultati študij kažejo, da motivacija za učenje vpliva na učne strategije učencev (Watkins in Akande, 1994). Faktorske analize so namreč pokazale, da se povezanost med motivacijo za učenje in učnimi strategijami izkazuje v treh oblikah pristopov učencev k učenju: (i) v obliki površinskega pristopa $\mathrm{k}$ učenju, ki se nanaša predvsem na pomnjenje in reprodukcijo znanja, (ii) v obliki globinskega pristopa do učenja, ki se nanaša predvsem na zanimanje za učno snov in razumevanje, ter (iii) v obliki stališča do uspeha, ki se nanaša na motivacijo za najvišje možne dosežke, tako v zvezi z učenjem kot v zvezi z akademsko samopodobo.

$\mathrm{Na}$ splošno je pojasnjevanje virov motivacije razdeljeno na ekstrinzične (vire, ki so izven osebnosti) in intrinzične (osebnostne, notranje vire motivacije). Zunanji viri motivacije vključujejo klasično pogojevanje, izkustveno pogojevanje, posnemanje (imitacijo) in učenje z vživljanjem (igro vlog). Notranji viri motivacije pa se delijo na naslednja področja: telesne (biološke, fizične), umske oziroma duševne, kognitivne (mišljenjske), afektivne oziroma čustvene, konativne oziroma voljne in spiritualne (duhovne, nadosebne vire). Aktivno ali pasivno motivacijo za učenje lahko sprožijo pozitivne ali negativne spodbude, ki izhajajo bodisi iz okolja bodisi iz osebnostne strukture posameznika ali pa iz kombinacije obeh. Vire motivacijskih sil za učenje pri učencih delimo v šest kategorij (Dweck, 1986). Vedenjski ali zunanji viri vključujejo izvabljanje (angl. »elicitation«) s spodbujanjem, doseganje želenih, prijetnih posledic (nagrad) ali izogibanje neželenim, neprijetnim posledicam in posnemanje pozitivnega vedenja. Glavni subjekti pri tem so učitelj, učenec, starši, šola in družbeno okolje. Biološki viri zajemajo povečanje/zmanjšanje stimulacije (vneme, gorečnosti), aktiviranje čutov (okus, dotik, vonj itd.), zmanjšanje lakote, žeje, neudobja itd. in ohranjanje homeostaze oziroma ravnotežja. Glavni subjekti pri teh virih so učenci, učitelji, starši in šola. Afektivni ali čustveni viri se nanašajo na povečanje/zmanjšanje čustvene disonance, povečanje dobrih občutkov, zmanjšanje slabih občutkov, povečanje zaupanja vase in zmanjšanje grožnje temu zaupanju ter ohranjanje stopnje optimizma in navdušenja (navdiha). Glavni subjekti v okviru čustvenih virov so učenci in učitelji. Kognitivni ali mišljenjski viri vključujejo ohranjanje pozornosti do nečesa zanimivega ali 
nevarnega, razvoj smisla ali razumevanja, povečanje ali zmanjšanje kognitivnega neravnotežja in negotovosti, reševanje problemov, sprejemanje odločitev nekaj iznajti, nečesa se domisliti, in odstranitev grožnje ali tveganja. Glavni subjekti pri tem so učenci, učitelji, starši ter šolski sistem. Konativni ali voljni viri zajemajo določitev individualno razvitega in izbranega cilja, sledenje osebnim sanjam, nadzor nad svojim življenjem, odstranitev groženj, da si izberemo cilj ter znižanje nadzora drugih nad svojim življenjem. Konativni viri pravzaprav pomenijo samostojnost življenja in mišljenja oziroma avtonomnost. Glavni subjekti v okviru teh virov so učenci, učitelji, starši in šola. Spiritualni ali duhovni viri pa se nanašajo na razumevanje smisla oziroma namena svojega življenja ter povezovanje sebe s končnostjo neznanega. Glavni subjekti v okviru duhovnih virov so učitelji, starši ter širše družbeno okolje (družbeni, kulturni, ekonomski in politični podsistem). Ker je vsaka pobuda za učenje (vedenjska spodbuda) utirjena v zgoraj opisani pojmovni okvir, domnevamo, da je obstojnost motivacije za učenje bolj povezana z emocijami, konkretno spodbujanje za učenje pa je bolj povezano z notranjimi in zunanjimi motivi, ki jih preskrbijo celoten osebnostni potencial učenca, učitelji, šola kot celota in širše družbeno okolje ter starši.

Motivacijo za izobraževanje v splošnem najbolj pogosto opisujemo z notranjimi ali intrinzičnimi in zunanjimi ali ekstrinzičnimi dejavniki (Deci in Ryan, 1985). Race (1998) meni, da je notranja ali intrinzična motivacija povezana z željo po izobraževanju. Intenziteta želje po izobraževanju je odvisna od mnogih dejavnikov. Avtor navaja naslednje:

a) interes za posamezne študijske teme

b) željo po uspehu na različnih učnih področjih

c) željo posameznika, da pokaže drugim in sebi, da lahko doseže uspeh

d) spoštovanje učiteljev in njihovega dela

e) zadovoljstvo z učnimi materiali

f) spodbude, ki jih posameznik dobiva od predavateljev (učiteljev)

g) spodbude in opora drugih pomembnih oseb v teku izobraževanja

Zunanja ali ekstrinzična motivacija je definirana s potrebo po učenju. Zanjo je značilno, da se posameznik uči zaradi zunanjega vzroka. To so lahko ocene, pritisk staršev, nagrada ob koncu šolskega leta itd. Govorimo o situacijah:

a) kadar snov ali tema ni zanimiva

b) ko gre za snov ali tematiko, ki se je posameznik stežka nauči, a pelje k drugi,

bolj zanimivi in pomembni temi 
c) ko se mora posameznik izkazati sposobnega na nekem področju, preden sam ugotovi, ali ga to področje zanima in ali bi se želel o njem kaj naučiti

d) ko doživlja pritisk drugih, želje po učenju pa nima ali je le-ta na nizki stopnji

e) ko se mora učiti zaradi ocen

Če sta želja in potreba po učenju enako močni in se prepletata, se motivacija za izobraževanje zviša. Nasprotno je, če so zunanje zahteve močnejše od želje po učenju: v takšnih primerih posameznik zunanje spodbude lahko doživlja kot pritisk, kar dolgoročno privede do upada motivacije za izobraževanje.

Hidi (2000) navaja, da motivacija (vključno z motivacijo za učenje) sloni na dveh tipih interesov: situacijskemu in individualnemu. Situacijski interes se razvije, ko posameznikovo pozornost pritegne neko dogajanje iz okolja in sproži njegovo pozitivno ali negativno reakcijo. Začetno fazo situacijskega interesa, v kateri se pozornost zbuja in povečuje, imenuje inicialni ali sprožilni interes (angl. »triggering interest «). Ta je lahko kratkotrajen. Če je pozornost dalj časa usmerjena na določen dogodek ali osebe, se trajanje inicialnega ali sprožilnega interesa podaljša. Tako nastane vzdrževalni interes (angl. »maintained interest «). Situacijski interes $\mathrm{v}$ določenem času, $\mathrm{v}$ katerem posameznik poveča svoja znanja in razvije pozitivne občutke ter vrednote, preraste v individualni interes (Hidi, 2000; Krapp, 1998). Hidi in Harackiewicz (2000) poudarjata, da posameznik lahko razvije intrinzično motivirano vedenje le, če zmore ohranjati inicialni situacijski interes. Raziskovanje individualnih interesov kaže, da so ti pomembna determinanta akademske motivacije in učenja (Ainley, 1994; Krapp, 1998; Renninger, 2000; Schiefele in Krapp, 1996).

Sodobnejši pogledi na motivacijo za izobraževanje poudarjajo pomen ciljne motivacije kot prediktorja uspešnosti v akademskem delu. Cilji so kognitivne reprezentacije posameznikovih stremljenj v različnih situacijah, v katerih si prizadeva doseči uspeh (Yeung in Yeung, 200I). McInerney, Yeung in McInerney (2000) navajajo, da ima lahko različno razumevanje ciljev dramatične posledice za doseganje uspeha v izobraževanju. McInerney, Roche, McInerney in Marsh (1997) so v svojih raziskavah ugotovili, da ima ciljna motivacija multidimenzionalno strukturo. $\mathrm{V}$ osnovi ciljne motivacije je posameznikovo prepričanje, da lahko doseže uspeh v izobraževanju le z osebnimi napori in prizadevanji, pri čemer naj bi bilo učenje intrinzični motivacijski dejavnik (za katerega je značilna želja in interes po znanju). Pri tem so zelo pomembni posameznikov odnos do znanja in vloženega lastnega napora pri doseganju postavljenih ciljev in samozaznava lastnih sposobnosti za akademsko delo (izobraževanje in učenje). Uspešno načrtovanje in doseganje ciljev je povezano z njegovimi osebnostnimi značilnostmi in vrednostnim sistemom. Ta ocena je pod 
nenehnim vplivom povratne informacije iz okolja (t. i. socialni feedback), ki je dejavnik zunanje motivacije. Posameznik, za katerega je značilna osredotočenost na to, kako bo kaj naredil in kako se bo izkazal pred drugimi (ego orientacija - zunanji kriterij), bo svoj dosežek ali uspeh ovrednotil na osnovi odziva okolja ali članov skupine. Takšnemu posamezniku je veliko do tega, da se izkaže pred skupino, zato je njegova lastna ocena uspešnosti odvisna od zunanjih kriterijev, torej reakcij in spodbud okolja ali zanj pomembnih posameznikov. Posameznik, za katerega je značilna osredotočenost na nalogo (angl. »task orientation $\ll)$, pa v večji meri računa na lastna znanja in sposobnosti pri učenju in reševanju nalog, zato je bolj neodvisen od spodbud iz okolja in s tem tudi bolj samostojen.

\section{Tekmovalnost in motivacija}

Tekmovalnost v psihologiji predstavlja neodvisno psihično entiteto, ki jo lahko razumemo na različne načine: kot človekovo vrednoto, njegovo lastnost ali kot motiv. Tekmovalnost je zelo širok pojem, dežniški izraz za različne psihološke značilnosti posameznika, ki izvirajo iz stopnje dominacije določene vrste motiva pri posamezniku. V tem smislu je tekmovalnosti toliko vrst, kolikor je različnih motivov (biti boljši od drugega, prekositi sebe itd.).

Tekmovalnost je v različni izrazitosti zelo pomembna tudi za samopodobo. Če je oseba tekmovalna v odnosu do sebe (stremi k doseganju svojih potencialov), ima običajno pozitivno, dobro razvito samopodobo. Oseba, ki teži k preizkušanju lastnih sposobnosti do izčrpanosti, pa navadno izkazuje nizko ali krhko samopodobo. Enako je pri posameznikih, ki želijo premagati druge: za tem se pogosto skriva nizko samospoštovanje, ki za kratek čas naraste, ko oseba premaga drugega.

Riskind in Wilson (1982) menita, da je osnova tekmovalnosti zadovoljstvo, ki ga posameznik doživlja v tekmovalni situaciji ali v medsebojnem tekmovanju; doživljanje zadovoljstva je motiv, da nekaj naredi boljše kot drugi. Smither in Houston (1992) pa navajata, da je najmočnejši tekmovalni motiv potreba po dosežkih in po uspehu.

Franken in Brown (1995) sta ugotovila, da so v okviru motivacije za tekmovalnost najmočnejši naslednji motivi:

a) želja in prizadevanje posameznika, da zmaga in izloči drugega

b) preizkušanje lastnih sposobnosti: fizičnih sposobnosti (npr. tekaški marato-

ni), ustvarjalnih sposobnosti, kognitivnih sposobnosti

c) narediti nekaj najboljše, kar lahko, in tako napredovati

d) zadovoljstvo zaradi dobro opravljene naloge

e) izbiranje zahtevnih in težkih nalog 
Želja po preizkušanju lastnih sposobnosti v tekmovalni situaciji torej ne izvira vedno iz želje po zmagi. Za tekmovalnost sta značilni dve smeri: (a) igranje, nastopanje, tekmovanje proti drugim in (b) prizadevanje, da bi neko nalogo opravili boljše od drugih. Za prvo dimenzijo je značilna medsebojna tekmovalnost, ki se izkazuje skozi željo tekmovalca, da premaga druge. Drugo pa zaznamuje stremljenje k doseganju zastavljenih ciljev ne le narediti nekaj boljše kot drugi, ampak narediti nekaj najboljše, kar lahko (Griffin-Pierson, 1990). Po Frankenu in Brownu (1995) ima druga dimenzija tekmovalnosti največji pomen v razumevanju le-te: avtorja namreč menita, da je to tista tekmovalnost, skozi katero posameznik stremi k doseganju kriterija odličnosti in je nujno povezana s ciljno in storilnostno motivacijo ter napredovanjem posameznika.

Podobno tudi Ryckman, Hammer, Kaczor in Gold (1996) menijo, da obstajata dve vrsti tekmovalnosti: hipertekmovalnost in tekmovalnost kot osebnostna rast. Za hipertekmovalnost so značilni:

- težnja k doseganju cilja, ne glede na sredstva

- težnja $\mathrm{k}$ tekmovanju in zmagi in k izogibanju neuspeha (zmaga za vsako ceno)

- $\quad$ skrb samo zase (agresivnost, manipulacija, izkoriščanje drugih)

- visoko vrednotenje dosežkov, hedonizem, moč, stimulacija (adrenalin), nagnjenost k egocentričnosti

- težnja po superiornosti

- tekmovanje tudi v situacijah, ki niso tekmovalne narave (npr. med prijatelji)

Za tekmovalnost kot osebnostno rast pa je značilno naslednje:

- glavni poudarek ni na zmagi, temveč si posameznik z izkušnjami, ki jih je pridobil v tekmovalnih situacijah, pomaga k lastnemu osebnostnemu razvoju

- osredotočenost na prvine samorazvoja, odkrivanje samega sebe in svojih potencialov

- $\quad$ stalen kritičen odnos do lastnega razvoja

- merila odličnosti, doseganje postavljenih ciljev z namenom napredovanja, narediti nekaj najboljše, kar lahko.

V okviru povezanosti med motivacijo in tekmovalnostjo raziskave kažejo, da tekmovalne situacije zmanjšujejo intrinzično motivacijo, pri čemer pa je pomembna tudi vloga temeljnih psihičnih potreb. Reeve in Deci (1996) sta preučevala učinek tekmovalnosti na intrinzično motivacijo udeležencev v različnih okoljih. Ugotovila sta, da pritisk na udeležence v smeri doseganja zmage prek spodbujanja tekmovalnosti v nadzorovanem okolju 
vodi do zmanjšanja intrinzične motivacije, medtem ko ima tekmovalnost v nenadzorovanem (nekontroliranem) okolju manjši učinek na spremembe v intrinzični motivaciji, pri čemer je bila pomemben mediator zaznava lastne avtonomnosti pri udeležencih. Podobno je tudi Tripathi (1992) ugotovil, da neposredna tekmovalnost z drugo osebo v kombinaciji z informacijami, vezanimi na kontrolo, vodi do boljše učinkovitosti, medtem ko posredna tekmovalnost in povratne informacije, vezane na kompetentnost, vodijo do večje intrinzične motivacije. Tauer in Harackiewicz (2004) pa sta preučevala učinek tekmovalnosti in sodelovanja na intrinzično motivacijo. Rezultati so pokazali, da tekmovalnost in sodelovanje sama po sebi ne povzročata razlik v zadovoljstvu ali učinkovitosti pri opravljanju naloge. Kombinacija tekmovalnosti in sodelovanja (torej tekmovanje med skupinami) pa je konsistentno povečevala intrinzično motivacijo in v večini primerov tudi učinkovitost. Avtorja zaključujeta, da imata tako tekmovalno kot sodelovalno vedenje pozitivne vidike in da lahko s strukturiranjem dejavnosti v smislu vključevanja obeh povečujemo tako intrinzično motivacijo kot učinkovitost.

\section{Samospostovanje in motivacija}

Samopodobo razumemo kot množico odnosov, ki jih posameznik - zavestno ali nezaved no - vzpostavlja do samega sebe (Kobal, 200o). Samopodoba je organizirana celota lastnosti, potez, občutij, podob, stališčc, sposobnosti in drugih psihičnih vsebin, za katere je značilno, da:

a) jih posameznik - v različnih stopnjah razvoja in v različnih situacijah - pripisuje samemu sebi,

b) tvorijo referenčni okvir (Musek, 1985), s katerim posameznik uravnava in usmerja svoje ravnanje,

c) So $\mathrm{v}$ tesni povezavi $\mathrm{z}$ obstoječim vrednostnim sistemom posameznika ter $\mathrm{z}$ vrednostnim sistemom ožjega in širšega družbenega okolja in

d) so pod nenehnim vplivom delovanja obrambnih mehanizmov.

Jaz in samopodoba orientirata posameznika $v$ stvarnosti, integrirata in nadzirata njegovo delovanje, ga organizirata, spodbujata in usmerjata (Musek, 2005). Težnja po vzdrževanju pozitivne samopodobe in samospoštovanja je eden najmočnejših posameznikovih motivov. Samopodoba deluje selektivno pri izboru in predelavi informacij ter skupaj z jazom predstavlja osnovo posameznikove samodejavnosti in samoregulacije. Navadno delujeta nezavedno, pogosto pa tudi zavestno. 
Samospoštovanje predstavlja pozitivno ali negativno stališče posameznika do sebe (Rosenberg, 1989), torej gre za vrednostni vidik samopodobe. Visoko samospoštovanje pomeni, da se posameznik sprejema takšnega, kot je, da se ceni, da je zadovoljen sam s seboj in da se čuti vrednega spoštovanja. Nizko samospoštovanje pa se kaže v nezadovoljstvu s samim seboj in neodobravanju svojih lastnosti. Posameznikovo samospoštovanje se oblikuje skozi dva medsebojno povezana procesa (McMullin in Cairney, 2004): (i) Posameznik primerja svojo socialno identiteto, mnenja in sposobnosti z drugimi. V kolikor se $\mathrm{v}$ primerjavi z ljudmi, s katerimi je v interakciji, počuti manjvrednega, bo to negativno vplivalo na njegovo samospoštovanje. (ii) Posameznik ocenjuje samega sebe skozi interakcijo $z$ drugimi. Nauči se videti samega sebe na način, kot ga vidijo drugi. Če pomembni drugi posameznika ne cenijo, bo imel tudi sam o sebi negativno mnenje.

Tako kot v okviru samopodobe se tudi pri samospoštovanju mnenja o strukturi tega konstrukta precej razlikujejo. Nekateri menijo, da gre za enodimenzionalen konstrukt (npr. Rosenberg, 1989), drugi, da gre za večdimenzionalen pojav (Shavelson et al., 1976). Najbolj uveljavljeno pa je prepričanje, da samospoštovanje sestavljata dve dimenziji, in sicer kompetentnost (splošen občutek učinkovitosti) in samougajanje (splošen občutek socialne vrednosti) (Tafarodi in Swann, 200I). Samougajanje je del samospoštovanja, ki je odvisen od družbe in se oblikuje prek zrcaljenja. Občutek kompetentnosti pa izhaja iz splošnega občutka posameznika kot sposobne, efektivne osebe, ki se ima pod nadzorom, iz uspešne manipulacije posameznikovega okolja in realizacij njegovih ciljev.

Rosenberg (1989) je pojmoval samospoštovanje kot osebnostno lastnost, ki je stabilna tako v času kot v različnih situacijah. Nekateri raziskovalci (npr. Markus in Kunda, 1986) pa zagovarjajo procesni pristop k samospoštovanju. Samospoštovanje naj bi bilo torej »variabilno stališče o sebi, ki večinoma odraža temeljno oziroma standardno evalvacijo sebe, vendar upošteva manjše odklone od te osnove kot funkcijo spreminjanja vlog, pričakovanj, akcij in drugih karakteristik« (Kobal Grum in Avsec, 2007: 94). Tudi raziskave potrjujejo, da situacijski faktorji lahko vplivajo na trenutne spremembe v ocenjevanju sebe in lastne vrednosti (npr. Baumgardner et al., 1989). V nasprotju s samopodobo, kjer variabilnost ne predstavlja optimalnega psihičnega funkcioniranja, v okviru samospoštovanja novejše raziskave kažejo, da je določena mera nestabilnosti še vedno optimalna (Kernis in Goldman, 2005). Variabilnost samospoštovanja se kaže v nihanju od pozitivnega k negativnemu vrednotenju sebe in obratno. To nihanje naj bi odražalo krhka in ranljiva občutja lastne vrednosti, na katere vplivajo za samopodobo potencialno relevantni dogodki, ki so lahko sproženi od zunaj (npr. kompliment) ali od znotraj (Kernis in Paradise, 2002). Kot 
vzroke nestabilnega samospoštovanja avtorji navajajo predvsem osiromašeno samopodobo, pa tudi pretirano zanašanje na ocene, ljubezen in odobravanje s strani drugih ter pretirane potrebe po odvisnosti. V primerjavi z ljudmi s stabilnim samospoštovanjem se pri posameznikih z nestabilnim samospoštovanjem pri soočanju z vsakdanjimi ovirami ali stresnimi življenjskimi dogodki v večji meri pojavljajo simptomi depresivnosti (Kernis et al., I998). Raziskave kažejo tudi, da so pri ljudeh z nestabilnim samospoštovanjem občutja o sebi bolj pod vplivom vsakodnevnih pozitivnih in negativnih dogodkov (Greenier et al., 1999), prav tako pa imajo tudi bolj osiromašeno samopodobo (Kernis et al., 2000). Pri učenju zavzemajo položaje, ki ščitijo samospoštovanje, so manj odločni pri prizadevanjih za dosego svojih ciljev ter se bolj osredotočajo na tiste vidike medosebnih dogodkov, ki ogrožajo samospoštovanje (Waschull in Kernis, 1996).

Raziskave kažejo, da je samospoštovanje povezano tudi z zadovoljenostjo temeljnih psihičnih potreb. Zadovoljenost potreb po avtonomnosti, kompetentnosti in povezanosti je neposredno povezana s samoaktualizacijo, samospoštovanjem, razvojem jaza in drugimi indikatorji psihičnega blagostanja (Deci in Ryan, 1985). Teorija samodoločenosti predpostavlja, da nihanja v zadovoljenosti temeljnih potreb napovedujejo tudi nihanja v psihičnem blagostanju. Rezultati študij kažejo, da je zadovoljenost potreb po avtonomnosti, kompetentnosti in povezanosti pri zaposlenih pozitivno povezana s samospoštovanjem in splošnim zdravjem udeležencev (Ilardi et al., 1993) ter negativno povezana $\mathrm{z}$ anksioznostjo in somatizacijo (Baard et al., 2004). Baumeister in Tice (1985) sta preučevala samospoštovanje in intrinzično motivacijo kot odziv na uspeh oziroma neuspeh. Predpostavila sta, da je cilj ljudi z visokim spoštovanjem razvoj lastnih sposobnosti z namenom doseganja odličnosti, cilj ljudi z nizkim samospoštovanjem pa izboljšanje lastnih pomanjkljivosti z namenom doseganja ustreznosti. V eksperimentu so udeleženci po opravljeni aktivnosti prejeli takojšnje povratne informacije o uspehu, neuspehu zaradi notranjih dejavnikov ali neuspehu zaradi zunanjih dejavnikov. Avtorja sta pri udeležencih merila intrinzično motivacijo za vključevanje $\mathrm{v}$ aktivnost $\mathrm{v}$ prostem času. Udeleženci z visokim samospoštovanjem so imeli najvišjo raven intrinzične motivacije po uspehu, udeleženci z nizkim samospoštovanjem pa po neuspehu zaradi notranjih dejavnikov. Waschull in Kernis (1996) sta pri preučevanju samospoštovanja, intrinzične motivacije in jeze pri učencih ugotovila, da so imeli učenci $z$ nižjim samospoštovanjem nižje rezultate $v$ okviru radovednosti, interesa in želje po izzivih. Rezultati so pokazali tudi, da samoocene kompetentnosti za šolsko delo vplivajo tako na stabilnost kot raven samospoštovanja ter da so dnevna nihanja v teh samoocenah tako prepletena s stabilnostjo samospoštovanja, da z nobenim od teh kon- 
struktov ne moremo samostojno napovedati učenčevega interesa in želje po novih izzivih. Nestabilnost samospoštovanja pa je bila pozitivno povezana tudi z doživljanjem jeze kot posledice dogodkov v medosebnih odnosih, ki ogrožajo samospoštovanje.

\section{Cilji raziskave}

V raziskavi smo želeli ugotoviti povezanost med motivacijo za izobraževanje, tekmovalnostnimi naravnanostmi in različnimi področji samopodobe oziroma samospoštovanja. V okviru tega smo preučili tudi motivacijo za tekmovalnost ter odnos med omenjenimi konstrukti in psihološkimi dimenzijami, kot so čustva in temeljne psihične potrebe. Zanimale pa so nas tudi razlike glede na spol študentov in njihovo smer študija.

Opis raziskave

Udeleženci. V raziskavi je sodelovalo 409 študentov različnih letnikov (večinoma prvega in drugega, manjši del pa tudi višjih letnikov) s sedmih fakultet Univerze v Ljubljani (Filozofska fakulteta, Biotehniška fakulteta, Fakulteta za matematiko in fiziko, Fakulteta za gradbeništvo, Medicinska fakulteta, Fakulteta za strojništvo, Fakulteta za kemijo in kemijsko tehnologijo), treh fakultet Univerze v Mariboru (Ekonomsko-poslovna fakulteta, Fakulteta za varnostne vede, Fakulteta za kmetijstvo in biosistemske vede) ter Evropske pravne fakultete v Novi Gorici. Med udeleženci je bilo 122 moških (30 \%) in 287 žensk (70 \%). Starostni razpon udeležencev je bil od i 8 do 55 let $s$ povprečno starostjo 21, Is let $(S D=4,6)$. Povprečna ocena udeležencev je bila $8,325(S D=\mathrm{I}, 0 \mathrm{I})$.

Pripomočki. Za izvedbo raziskave smo uporabili devet uveljavljenih psiholoških vprašalnikov in lestvic. Lestvica motivacije za izobraževanje AMS-HS (Vallerand, Pelletier, Blais, Briere, Senecal in Vallieres, 1992) meri naslednje vidike motivacije za izobraževanje: (i) intrinzična motivacija - védenje, (ii) intrinzična motivacija - dosežki, (iii) intrinzična motivacija - občutenje stimulacije, (iv) ekstrinzična motivacija - identificirana regulacija, (v) ekstrinzična motivacija - introjektirana regulacija, (vi) ekstrinzična motivacija - eksternalna regulacija in (vii) amotivacija. Zanesljivost vprašalnika za različne podlestvice znaša od o,70 (ekstrinzična motivacija - identificirana regulacija) do o,86 (amotivacija), v naši raziskavi od 0,50 do o,87. Stopnjo zadovoljenosti temeljnih psiholoških potreb na splošno v življenju smo merili z Vprašalnikom zadovoljitve temeljnih potreb GNSS (Gagne, 2003), ki vključuje tri lestvice: avtonomnost, povezanost in kompetentnost. Zanesljivost vprašalnika znaša $0,69 \mathrm{za}$ avtonomnost, 0,86 za povezanost in $0,7 \mathrm{I}$ za kompetentnost (Gagne, 2003),v naši raziskavi pa so se koeficienti gibali med o,6r in 0,79. Tekmovalnost smo preučevali s pomočjo dveh lestvic: Lestvico hipertekmovalnosti (Ryckman, Hammer, 
Kaczor in Gold, 1990) in Lestvico osebne tekmovalnosti (Ryckman, Hammer, Kaczor in Gold, 1996). Za lestvico hipertekmovalnost Ryckman in sodelavci (1990) navajajo visoko zanesljivost (Cronbachov alfa = 0,9I), avtorji slovenskega prevoda (Kobal Grum et al., 2005) pa nekoliko nižjo (Cronbachov alfa $=0,7 \mathrm{I}$ ). V naši raziskavi je bila zanesljivost enaka 0,77 . Podobne koeficiente avtorji navajajo tudi za lestvico osebne tekmovalnosti: 0,90 (Ryckman in sodelavci, 1996), 0,69 (Kobal Grum et al., 2005), v naši raziskavi pa je zanesljivost znašala 0,87 . Študija Ryckmana in sodelavcev (1996) je potrdila tudi ortogonalni odnos med osebno tekmovalnostjo in hipertekmovalnostjo, kot jo meri omenjena lestvica hipertekmovalnosti (Ryckman et al., 1990). Motivacijo za sodelovanje v tekmovalni situaciji smo merili z Vprašalnikom motivacije za tekmovalnost CMQ (Franken in Brown, 1995). Vprašalnik meri pet vidikov motivacije za tekmovalnost: (i) zadovoljstvo ob izboljšanju lastnih sposobnosti, (ii) željo po zmagi, (iii) motivacijo za vztrajanje in trud, da se oseba izkaže najboljše, kolikor se lahko, (iv) zadovoljstvo zaradi dobro opravljene naloge in (v) nagnjenje $\mathrm{k}$ izbiri zahtevnih nalog. Avtorji navajajo zanesljivosti posameznih podlestvic med 0,68 in 0,83 (Franken in Brown, 1995), v naši raziskavi pa smo ugotovili zanesljivosti med 0,53 in 0,75 . V okviru samospoštovanja nas je zanimala tako struktura samospoštovanja kot nekateri drugi vidiki, in sicer pogojenost in nestabilnost samospoštovanja. Uporabili smo Vprašalnik samospoštovanja SLSC-R (Tafarodi in Swann, 20or), ki meri dve dimenziji splošnega samospoštovanja: samougajanje in občutek kompetentnosti. Lestvica kompetentnosti meri del samospoštovanja, ki izhaja iz splošnega občutka posameznika kot sposobne, učinkovite osebe, lestvica samougajanja pa meri del samospoštovanja, ki je odvisen od družbe. Zanesljivost vprašalnika znaša o,90 za podlestvico smougajanja in o,82 za podlestvico kompetentnosti (Tafarodi in Swann, 200I), v naši raziskavi o,87 in 0,77. Lestvica pogojenega samospoštovanja CSES (Paradise in Kernis, 1999) meri stopnjo, do katere je posameznikovo samospoštovanje odvisno od doseganja standardov, uspeha in pozitivnih ocen s strani drugih ljudi. Zanesljivost lestvice (test-retest) po navedbah avtorjev znaša o,77 (Kernis in Goldman, 2006), v naši raziskavi pa o,78. Lestvica nestabilnosti samospostovanja ISES (Chabrol, Rousseau in Callahan, 2006) temelji na Rosenbergovi lestvici samospoštovanja in vsebuje postavke, ki se nanašajo na nasprotujoče si misli ali občutja do lastne vrednosti. Tako notranja kot test-retestna zanesljivost lestvice znaša o,89 (Chabrol et al., 2006), v tej raziskavi pa smo ugotovili zanesljivost o,88. Emocionalno stanje udeležencev smo merili z Vprašalnikom pozitivne in negativne emocionalnosti PANAS (Watson et al., I988), ki ga sestavljata dve lestvici: (i) pozitivna emocionalnost - stanje, v katerem se posameznik počuti dobro razpoloženega, navdušenega, aktivnega in pripravlje- 
nega za akcijo, ter (ii) negativna emocionalnost - stanje, v katerem je posameznik naravnan depresivno in tesnobno, je zaskrbljen in nervozen. Udeležence lahko sprašujemo po čustvenem stanju (i) v določenem trenutku, (ii) v zadnjih nekaj dnevih, (iii) v zadnjih nekaj tednih, (iv) v zadnjem letu ali (v) na splošno; v pričujoči raziskavi smo udeležence spraševali po splošnem doživljanju pozitivnih in negativnih čustvenih stanj. Avtorji za lestvico pozitivnega afekta ugotavljajo zanesljivost od o,47 do o,68, za lestvico negativnega afekta pa od 0,39 do 0,7I, odvisno od navodil. Najvišjo zanesljivost avtorji ugotavljajo pri opisu čustvenih stanj na splošno. $V$ tej raziskavi je bila zanesljivost enaka o,79 za pozitivno emocionalnost in 0,85 za negativno emocionalnost.

Sklopu opisanih vprašalnikov so bila dodana še vprašanja o spolu, datumu rojstva, starosti, smeri študija, letniku in povprečni oceni predmetov oziroma izpitov v preteklem šolskem letu.

Postopek. Glavni kriterij za izbor udeležencev je bil status študenta, pri čemer smo zajeli tako redne kot izredne študente različnih letnikov dodiplomskega in podiplomskega študija. Pri tem smo bili pozorni tudi na to, da smo k sodelovanju povabili študente različnih smeri (naravoslovja, tehnike, družboslovja, humanistike) z vseh slovenskih univerz. Udeleženci so izpolnjevali vprašalnike $\mathrm{v}$ tiskani in elektronski obliki. Udeležence, ki so vprašalnike izpolnjevali ročno, smo v vzorec izbrali priložnostno, in sicer študente, prisotne pri posameznih urah predavanj (v izvedbi avtoric raziskave in nekaterih drugih izvajalcev, ki so privolili v sodelovanje). Izpolnjevanje je potekalo tako, da smo udeležencem najprej posredovali informacije o namenu raziskave in anonimnosti odgovorov, nato pa še navodila za izpolnjevanje posameznih vprašalnikov. Izpolnjevanje je trajalo približno 20 minut. V tej skupini udeležencev so se za sodelovanje odločili vsi nagovorjeni študentje, pri čemer je bilo nepravilno oz. nepopolno izpolnjenih vprašalnikov en odstotek.

Udeležence, ki so vprašalnike izpolnjevali v elektronski obliki, smo vzorčili po metodi snežne kepe, in sicer je izpolnjevanje potekalo tako, da smo povezavo do spletnega vprašalnika posredovali različnim študentskim društvom, predstavnikom študentov oz. letnikov ali na poštne sezname posameznih letnikov. Študentje, ki so se odločili za sodelovanje, so vprašalnike nato izpolnili samostojno preko interneta. V tej skupini udeležencev je bil osip precej večji, saj je bilo 23 odstotkov vprašalnikov neustrezno izpolnjenih in s tem neprimernih za obdelavo. 


\section{Rezultati in razprava}

Motivacija, tekmovalnost in samospostovanje pri študentib različnega spola

V okviru primerjave med spoloma so rezultati pokazali, da med študenti in študentkami obstajajo statistično pomembne razlike na vseh področjih intrinzične motivacije: motivacije po védenju $\left(d f=\right.$ I, $F=$ I7.124, $\left.p=0.000, E t a^{2}=0.068\right)$, motivacije po dosežkih $(d f$ $\left.=\mathrm{I}, F=\mathrm{I} 3.370, p=0.000, E t a^{2}=0.054\right)$ in motivacije po občutenje stimulacije $(d f=\mathrm{I}, F$ $=8.087, p=0.005, E t a^{2}=0.034$ ). Pomembne razlike med spoloma smo ugotovili tudi na dveh področjih ekstrinzične motivacije: pri identificirani regulaciji $(d f=\mathrm{I}, F=20.117, p=$ $\left.0.000, E t a^{2}=0.079\right)$ ter introjektirani regulaciji $\left(d f=\mathrm{I}, F=8.910, p=0.003, E t a^{2}=0.037\right)$. $\mathrm{Na}$ vseh naštetih področjih so rezultati žensk pomembno višji od rezultatov moških. Razlike smo pa ugotovili tudi v okviru amotivacije $\left(d f=\mathrm{I}, F=\mathrm{r} 4.68 \mathrm{I}, p=0.000, E t a^{2}=0.059\right)$, kjer so dosežki moških pomembno višji od dosežkov žensk (Slika 9).

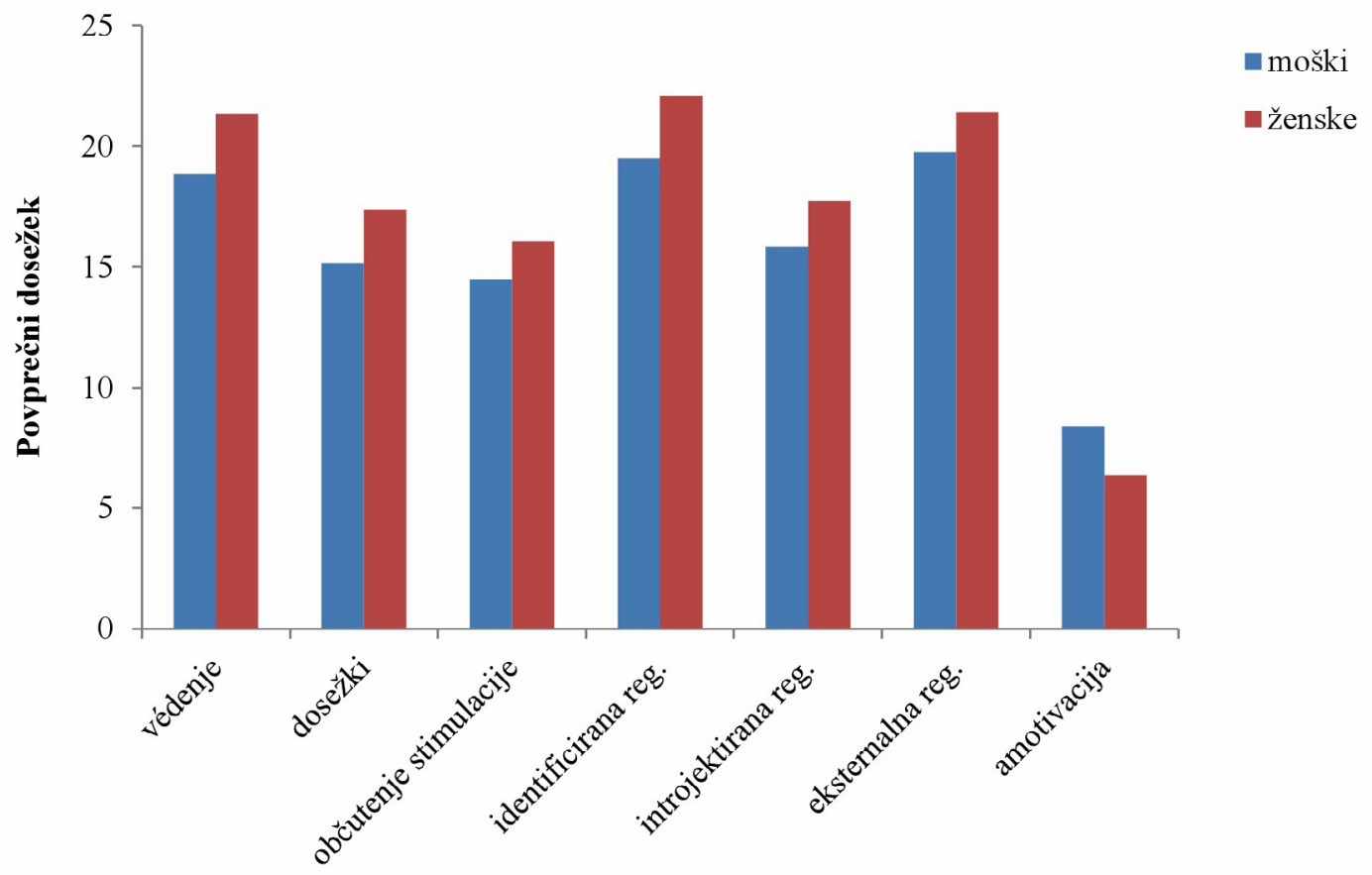

Motivacija za izobraževanje

Slika 9: Razlike med spoloma na različnih področjih motivacije za izobraževanje. 
Ti rezultati kažejo, da so študentke v večji meri notranje motivirane za študij kot študentje. Izbira študija oziroma poklica je pri študentkah skladnejša z njihovimi zanimanji in željami kot pri študentih. Po drugi strani pa študentke na področju izobraževanja tudi $\mathrm{v}$ večji meri sledijo nekim zunanjim kriterijem (za izbiro študijske smeri, za vrednotenje akademske uspešnosti itd.), s katerimi pa se v večji meri identificirajo oziroma so jih v procesu razvoja in odraščanja ponotranjile. Višji rezultati študentov v okviru amotivacije pa kažejo, da imajo moški manj definirane cilje na področju izobraževanja. Med njimi je torej več takih, ki v resnici ne vedo, zakaj se učijo oziroma zakaj so se odločili za neko študijsko smer ali poklic. Razlog pa je lahko tudi v tem, da jim študij ne predstavlja pomembne vrednote ali da dvomijo v lastne sposobnosti za dokončanje študija.

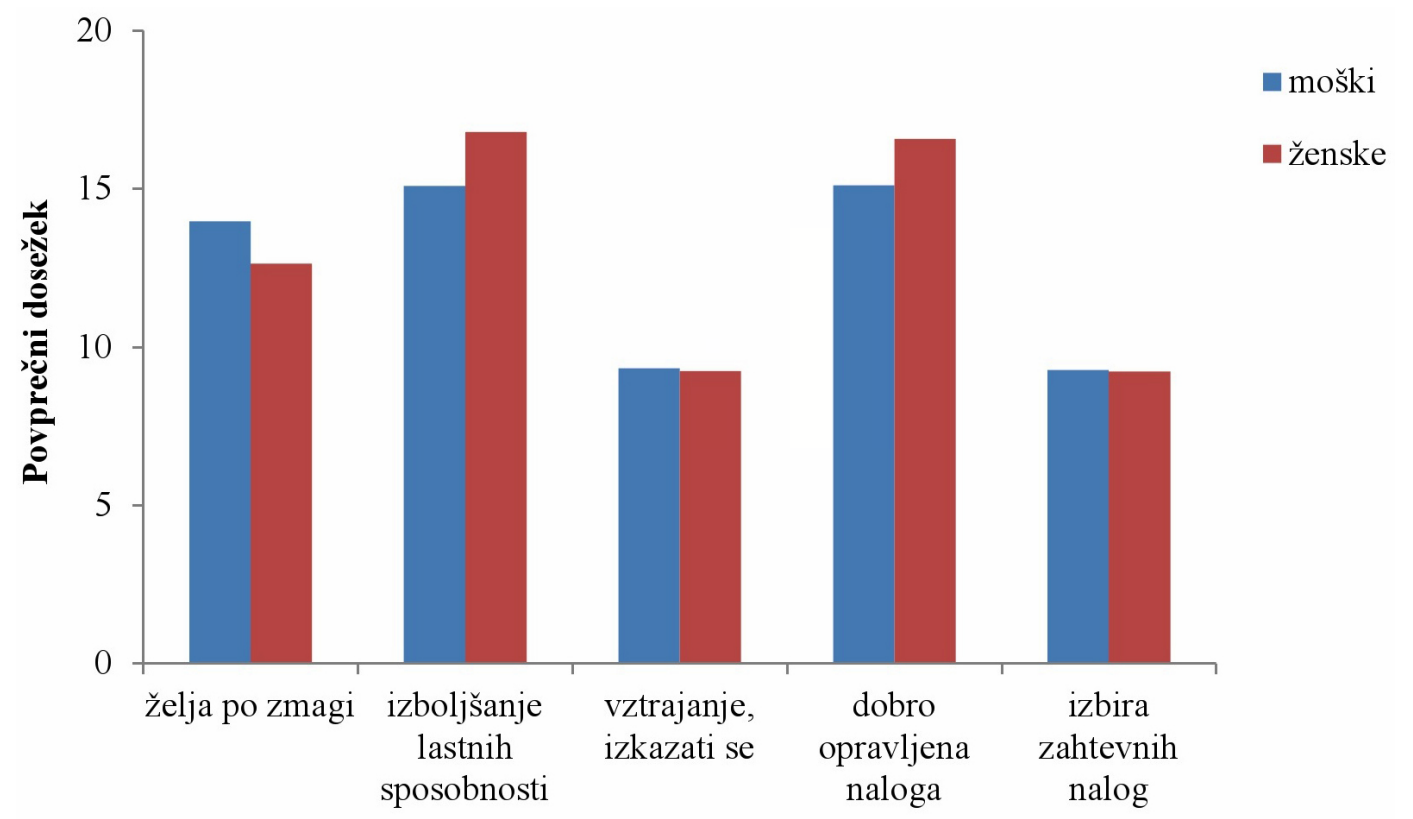

Motivacija za tekmovalnost

Slika ı: Razlike med spoloma v motivaciji za tekmovalnost.

Razlike med spoloma smo ugotovili tudi na področju motivacije za tekmovalnost (Slika Io). Medtem ko imajo moški pomembno višje izraženo željo po zmagi $(d f=\mathrm{I}, F=$ 5.987, $\left.p=0.015, E t a^{2}=0.025\right)$, pa ženske doživljajo višje zadovoljstvo ob izboljšanju lastnih 
sposobnosti $\left(d f=\right.$ I, $\left.F=29.595, p=0.000, E t a^{2}=0.113\right)$ ter dobro opravljenih nalogah $\left(d f=\right.$ I, $\left.F=27.457, p=0.000, E t a^{2}=0.105\right)$. Pri preizkušanju lastnih sposobnosti v okviru tekmovalnosti gre moškim torej bolj za to, da premagajo druge in se na tak način izkažejo, medtem ko ženske bolj stremijo k lastnemu napredovanju oziroma osebnostni rasti.

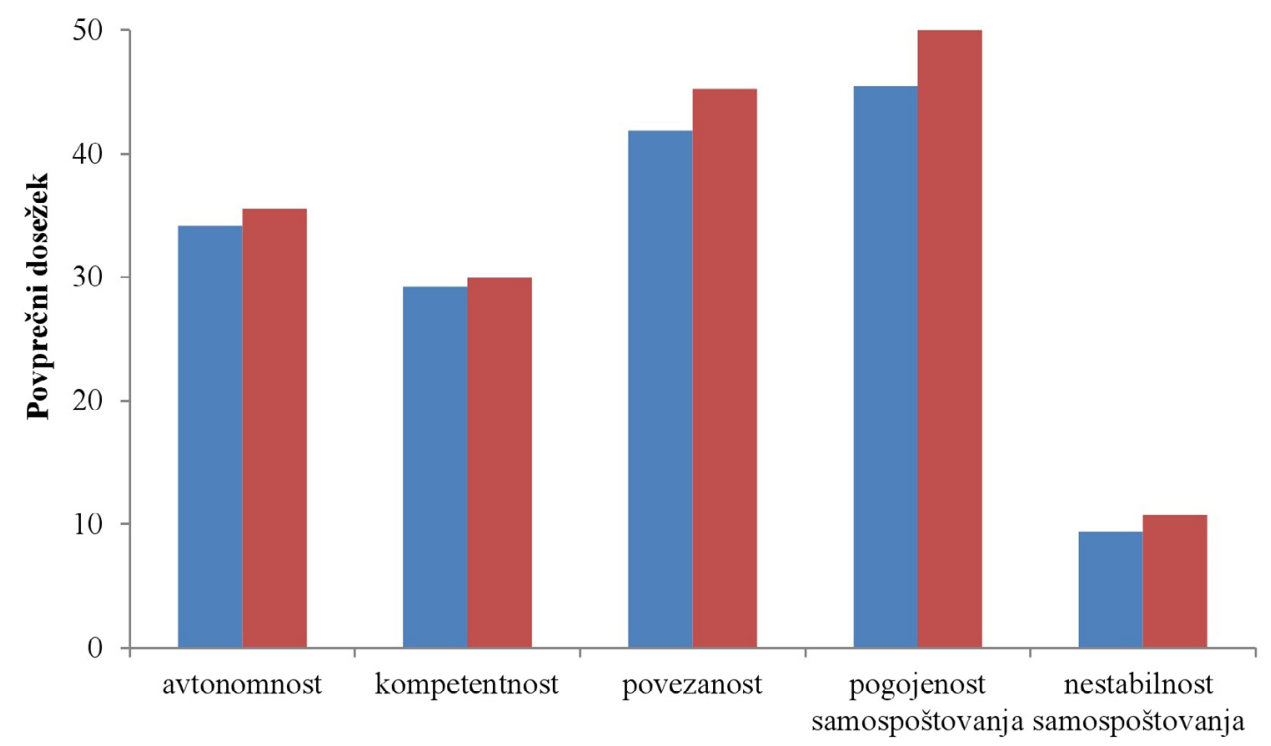

Temeljne psihične potrebe in samospoštovanje

Slika Ir: Razlike med spoloma v zadovoljenosti temeljnih psihičnih potreb ter pogojenosti in nestabilnosti samospoštovanja.

Prav tako so med spoloma opazne razlike v zadovoljenosti temeljnih psihičnih potreb (Slika I I), in sicer pri povezanosti, kjer imajo študentke višje rezultate od študentov $(d f=$ I, $F=13.738, p=0.000, E t a^{2}=0.056$ ). To pomeni, da imajo ženske večji občutek povezanosti s pomembnimi drugimi osebami kot moški. Razlike na tem področju verjetno izvirajo iz razlik v medosebnih odnosih na splošno: raziskave namreč kažejo, da v obdobju mladostništva moški in ženske oblikujejo različna prijateljstva in tudi v intimne odnose vstopajo na različne načine (Zupančič in Svetina, 2004). S prehodom v odraslost in kasnejšem odraslem obdobju pa se spremenijo tudi socialne vloge, ki z oblikovanjem družine in poklicne poti prav tako sooblikujejo odnose z drugimi in posledično občutek povezanosti z njimi (Zupančič, Kavčič in Fekonja, 2004). 
Rezultati prav tako kažejo, da se študenti in študentke pomembno razlikujejo tudi v pogojenosti $\left(d f=\right.$ I, $\left.F=18.967, p=0.000, E t a^{2}=0.075\right)$ in nestabilnosti samospoštovanja $\left(d f=\mathrm{I}, F=8.552, p=0.004, E t a^{2}=0.035\right)$, in sicer je samospoštovanje pri ženskah bolj pogojeno in manj stabilno (Slika I I). To pomeni, da samospoštovanje pri njih bolj niha v odvisnosti od življenjskih dogodkov (uspehov in neuspehov itd.) ter da ženske bolj pogojujejo lastno vrednost z doseganjem nekih kriterijev, ki si jih postavijo same ali pa jim jih določijo drugi. Samospoštovanje je pri študentkah torej bolj krhko kot pri študentih.

$\mathrm{Na}$ področju hipertekmovalnosti, osebne tekmovalnosti, dimenzij samospoštovanja ter pozitivne in negativne emocionalnosti med spoloma ni bilo razlik, kar pomeni, da imajo moški in ženske podobno visoko samospoštovanje, da doživljajo pozitivna in negativna čustva v podobni meri ter da noben spol ni bolj tekmovalen od drugega. V okviru primerjav med spoloma rezultati v splošnem potrjujejo izsledke prejšnjih raziskav, tj. da so ženske bolj motivirane za pridobivanje novega znanja, odkrivanje novih, zanimivih tem ter za razvijanje lastnih sposobnosti, medtem ko so moški bolj usmerjeni k dosežkom in uveljavitvi v smislu premagovanja drugih.

\section{Motivacija, tekmovalnost in samospostovanje pri študentih različnih študijskih}

\section{smeri}

Da bi preučili razlike med udeleženci glede na področje izobraževanja, smo jih razdelili v dve skupini, in sicer (a) družboslovje in humanistika $(N=3 \mathrm{I} 2)$ in (b) naravoslovje in tehnika $(N=93)$; za štiri udeležence nismo imeli podatka o smeri študija. V prvo skupino smo vključili študente andragogike, bibliotekarstva, ekonomije, prava in managementa nepremičnin, pedagogike (tudi v povezavi z drugimi področji v okviru dvopredmetnih študijev), psihologije, sociologije, slovenistike, turizma in varstvoslovja. V drugo skupino pa smo razvrstili študente biokemije, biotehnologije, fizike, geodezije, gradbeništva, kmetijstva, komunalnega inženirstva, medicine in strojništva.

Rezultati so pokazali, da se študentje družboslovja oz. humanistike ter naravoslovja oz. tehnike precej razlikujejo v motivaciji za izobraževanje (Slika I2), in sicer predvsem v intrinzični motivaciji, kjer so imeli študentje družboslovja in humanistike pomembno višje rezultate od študentov naravoslovja in tehnike. Študentje družboslovja in humanistike so bolj motivirani za védenje, torej večkrat izvajajo aktivnosti, povezane s študijem, zaradi užitkov in zadovoljstva pri učenju $\left(d f=\right.$ I, $\left.F=44.079, p=0.000, E t a^{2}=0.198\right)$. Ta skupina študentov je prav tako bolj motivirana za dosežke, kar pomeni, da doživljajo zadovoljstvo ob tem, ko poskušajo vsakič znova preseči sebe in svoje znanje $(d f=\mathrm{I}, F=\mathrm{1} 3.004, p=$ $\left.0.000, E t a^{2}=0.068\right)$. Poleg tega so bolj motivirani za stimulacijo in se v različne študijske 
aktivnosti vključujejo zaradi zabave, druženja, estetskih doživetij itd. ( $d f=$ I, $F=$ I I.322, $\left.p=0.001, E t a^{2}=0.059\right)$.

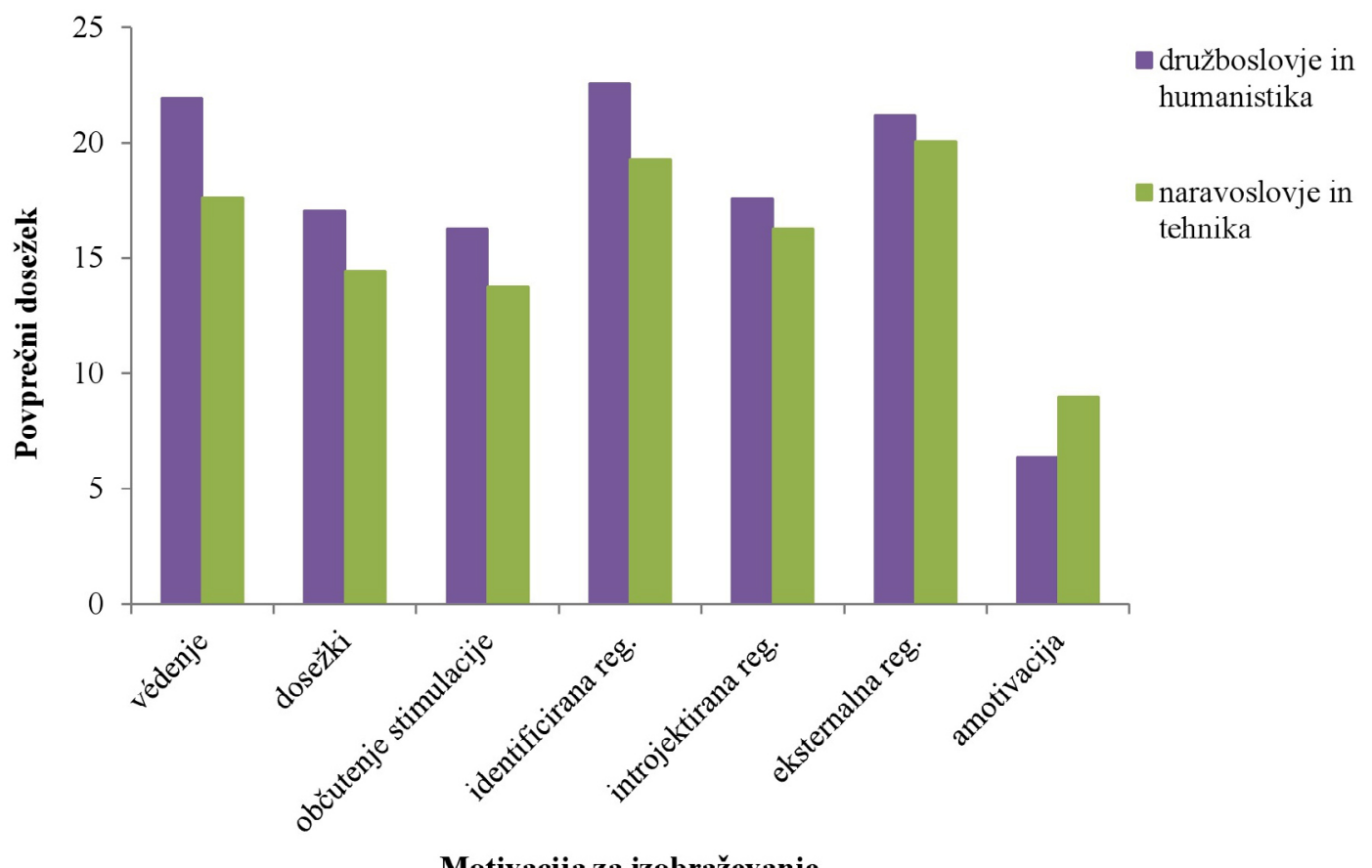

Slika I2: Razlike med študenti družboslovja in humanistike ter naravoslovja in tehnike na različnih področjih motivacije za izobraževanje.

Pomembne razlike so se pojavile tudi na področju identificirane regulacije v okviru ekstrinzične motivacije, kjer so bili rezultati študentov družboslovja in humanistike prav tako višji $\left(d f=\right.$ I $\left., F=29.793, p=0.000, E t a^{2}=0.143\right)$. Študentje družboslovja in humanistike se v večji meri posvečajo študiju na podlagi lastne izbire oziroma ker se jim to zdi pomembno. Nasprotne rezultate pa smo dobili v okviru amotivacije, kjer so imeli študentje naravoslovja in tehnike precej višje rezultate od študentov družboslovja in humanističnih smeri $\left(d f=\right.$ I, $\left.F=20.658, p=0.000, E t a^{2}=0.103\right)$. Pri tej skupini se torej večkrat pojavi stanje odsotnosti kakršne koli vrste motivacije.

Ti rezultati kažejo, da imajo študentje družboslovja in humanistike večjo (notranjo) željo po izobraževanju od študentov naravoslovja in tehnike. Med študenti družboslovja 
in humanistike je več takih, ki jih študij zanima in jim prinaša zadovoljstvo. Po drugi strani pa je med študenti naravoslovja in tehnike več takih, ki nimajo izoblikovanih ciljev na področju izobraževanja in pravzaprav ne vedo, zakaj so se odločili za določen študij oziroma se v njem ne najdejo.

Rezultati so pokazali tudi, da imajo študentje družboslovja in humanistike pomembno bolj zadovoljene vse tri temeljne psihične potrebe: avtonomnost $(d f=\mathrm{I}, F=2 \mathrm{1} .037, p=$ $\left.0.000, E t a^{2}=0.105\right)$, kompetentnost $\left(d f=\mathrm{I}, F=\mathrm{I} 6.444, p=0.000, E t a^{2}=0.084\right)$ in povezanost $\left(d f=\right.$ I, $\left.F=16.666, p=0.000, E t a^{2}=0.085\right)$. Ti študentje imajo večji občutek nadzora nad lastnimi dejanji, pri delu se čutijo uspešnejše in so tudi bolj povezani z drugimi ljudmi. Predvsem k povezanosti lahko do določene mere pripomore tudi sama narava študija, saj so družboslovne in humanistične smeri večinoma naravnane k skupinskemu delu oziroma delu z ljudmi, medtem ko so dejavnosti v naravoslovnih vedah pogosto individualne (delo v laboratorijih ipd.). (Ne)zadovoljenost temeljnih psihičnih potreb pri študentih naravoslovja in tehnike je lahko povezana tudi $\mathrm{z}$ amotivacijo pri tej skupini študentov, saj teorija samodoločenosti predpostavlja, da je nezadovoljenost temeljnih potreb hkrati vzrok in posledica amotivacijskih stanj (Ryan et al., 1995). Študentje, ki pri študijskih aktivnostih nimajo občutka svobodnega izbiranja, učinkovitosti in povezanosti, tako nimajo interesa, da bi v omenjenih aktivnostih sodelovali, hkrati pa njihova neudeležba v teh dejavnostih ne omogoča, da bi se v zvezi z njimi počutili kompetentne.

V okviru tekmovalnosti smo ugotovili, da so študentje naravoslovja in tehnike pomembno bolj hipertekmovalni $\left(d f=\mathrm{I}, F=\mathrm{I} 7.357, p=0.000, E t a^{2}=0.088\right)$. Njihova motivacija za tekmovalnost v večji meri kot pri drugi skupini študentov izvira iz želje po zmagi $\left(d f=\mathrm{I}, F=5.095, p=0.025, E t a^{2}=0.028\right)$, medtem ko so študentje družboslovja in humanistike bolj tekmovalni v smislu izboljšanja lastnih sposobnosti $(d f=\mathrm{I}, F=24.035, p=$

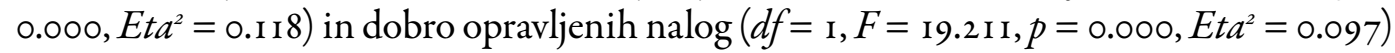
(Slika 5). Pri teh študentih torej prevladuje osebna tekmovalnost - odkrivanje lastnih potencialov, osebnostni razvoj in napredovanje, medtem ko tekmovalno vedenje študentov naravoslovja in tehnike izvira iz motiva po premagovanju drugih, ki pa se zaradi osredotočenosti na zmago lahko dolgoročno kaže tudi v slabših rezultatih oziroma nižji učinkovitosti.

Na področju samospoštovanja rezultati kažejo, da imajo študentje družboslovja in humanistike pomembno višje rezultate na obeh dimenzijah samospoštovanja, tako v okviru samougajanja $\left(d f=\mathrm{I}, F=7.890, p=0.006, E t a^{2}=0.042\right)$ kot kompetentnosti $(d f=\mathrm{I}, F$ $=$ II.31 $\left.4, p=0.001, E t a^{2}=0.059\right)$. Študentje družboslovja in humanistike imajo torej ve- 
čji občutek socialne vrednosti in se počutijo učinkovitejše. Po drugi strani pa je samospoštovanje pri tej skupini študentov tudi v večji meri pogojeno $(d f=\mathrm{I}, F=4.272, p=0.040$, $E t a^{2}=0.023$ ), torej pod vplivom doseganja različnih (zunanjih ali notranjih) kriterijev. Študentje, katerih študijska smer je bolj povezana z njihovimi interesi, se morda s študijem in svojim bodočim poklicem bolj identificirajo, zato imajo uspehi ali neuspehi na tem področju večji učinek na njihovo samospoštovanje - bolj torej pogojujejo lastno vrednost z uspehom pri študiju (Slika I3).

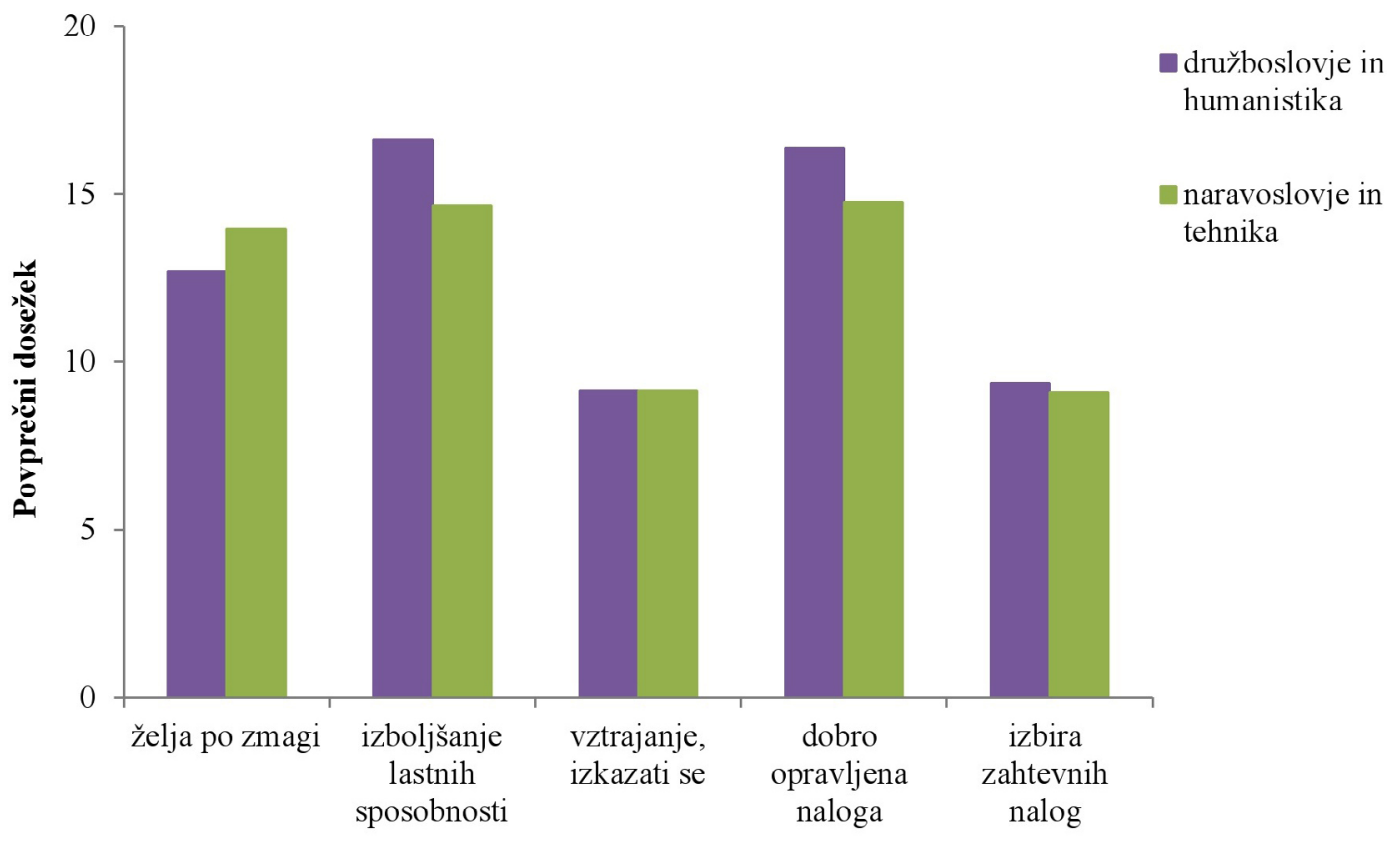

\section{Motivacija za tekmovalnost}

Slika I3: Razlike med študenti družboslovja in humanistike ter naravoslovja in tehnike v okviru motivacije za tekmovalnost.

Manjše, a pomembne razlike so se pojavile tudi pri pozitivni emocionalnosti $(d f=\mathrm{I}$, $\left.F=4.359, p=0.038, E t a^{2}=0.024\right)$, ki je višja pri študentih družboslovja in humanistike, kar pomeni, da ti študentje doživljajo nekoliko več pozitivnih čustev in razpoloženj (Slika I3). Na ostalih področjih pa statistično pomembnih razlik med obema skupinama študentov ni bilo. 


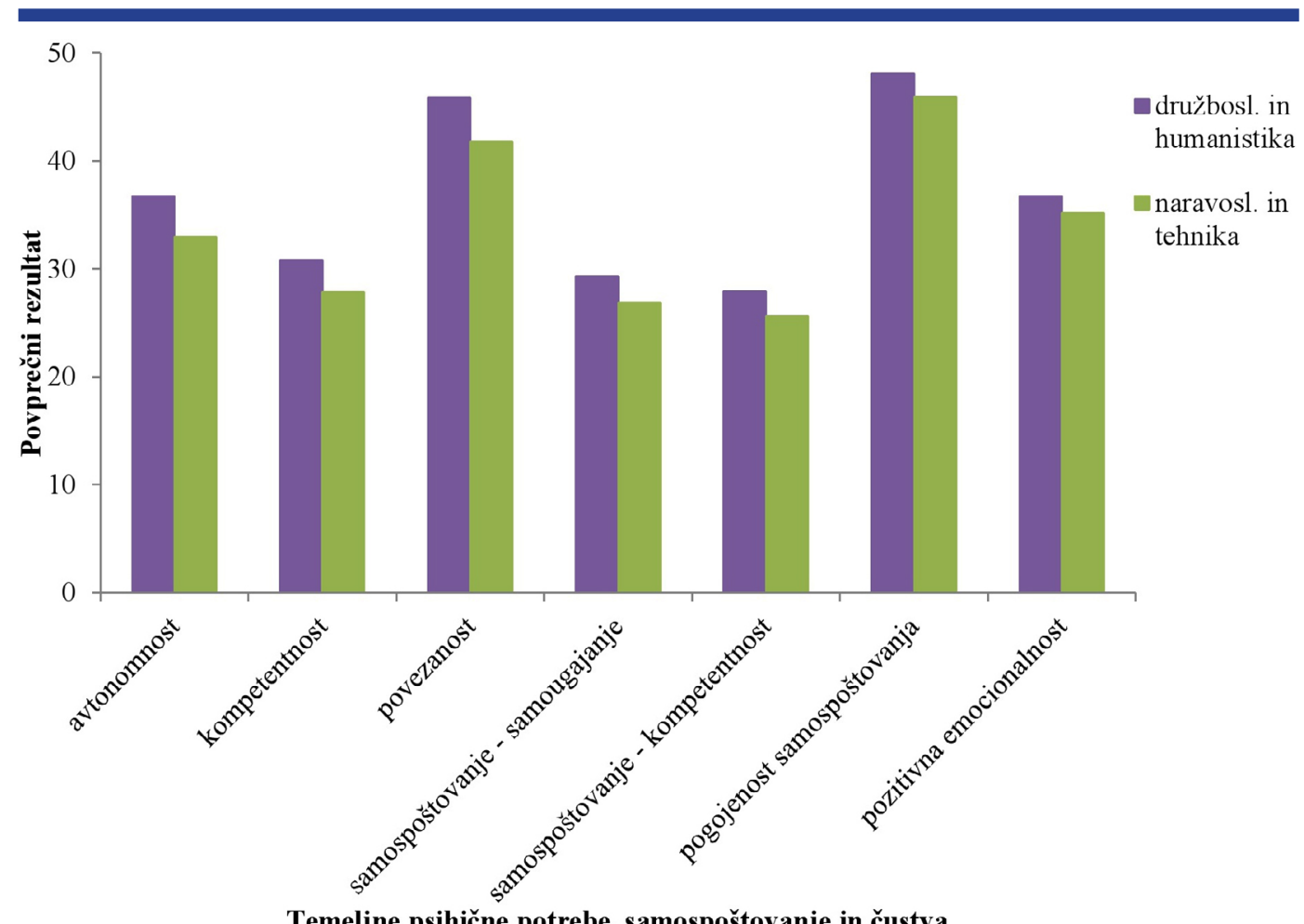

Slika I4: Razlike med študenti družboslovja in humanistike ter naravoslovja in tehnike v zadovoljenosti temeljnih psihičnih potreb, dimenzijah in pogojenosti samospoštovanja ter pozitivni emocionalnosti.

Medtem ko so rezultati, dobljeni v okviru primerjav med spoloma, večinoma skladni z izsledki predhodnih raziskav, pa primerjave študentov različnih smeri kažejo na specifično problematiko študentov naravoslovnih in tehničnih ved, in sicer zlasti na področju motivacije in tekmovalnosti. Predvidevamo, da je bilo v tej skupini več takih študentov, ki so si izbrali študij oziroma poklic bolj na osnovi zunanjih kot notranjih kriterijev. V družbi namreč velja prepričanje, da je v naravoslovnih in tehničnih vedah lažje najti zaposlitev, ker je diplomantov s teh področij manj, poleg tega pa so na družboslovnih ali humanističnih smereh pogosto tudi višje omejitve za sprejem na fakulteto. Ta dva dejavnika, ki imata pri vpisu na fakulteto $v$ mnogih primerih veliko vlogo, lahko vplivata na to, da si posameznik na koncu izbere študij, ki ga ne veseli tako zelo oziroma ki ni skladen z njegovimi dejanskimi zanimanji. Posledično je tudi motivacija za izobraževanje v takšni smeri drugač- 
na: namesto intrinzične motivacije (interesa za podano snov, zadovoljstva s študijem itd.) posameznika vodi ekstrinzična motivacija (pritisk s strani bližnjih, pričakovana zaposlitev ipd.). V tem primeru so zahteve močnejše od želje po učenju, kar pa po Race (1998) dolgoročno privede do upada motivacije za izobraževanje. Ta razlaga bi pojasnila tudi rezultate v okviru amotivacije, kjer so imeli študentje naravoslovja in tehnike precej višje rezultate od študentov družboslovja in humanističnih smeri. Amotivacija se namreč nanaša na odsotnost cilja oziroma motiva. Posameznik ne ve, zakaj se uči ali zakaj obiskuje določeno fakulteto, kar kaže na to, da se z izbranim področjem oziroma poklicem ne more identificirati in se ne vidi v njem. $Z$ neprostovoljno ali manj prostovoljno izbiro študijske smeri je lahko povezana tudi zadovoljenost temeljnih psihičnih potreb. Če študentu izbiro narekujejo zunanji pogoji, je pravzaprav pričakovano, da bo imel ob tem manjši občutek avtonomnosti, prav tako pa je zelo verjetno, da ne bo prepričan v lastne sposobnosti v tolikšni meri, kot če bi izbral študij, ki bi ga veselil in zanimal. Nezadovoljenost temeljnih psihičnih potreb pa se glede na ugotovitve Decija in Ryana (2000) kaže tudi v bolj negativnem doživljanju, manjši intrinzični motivaciji in slabši učinkovitosti posameznika. Le-ta je namreč bolj intrinzično motiviran za določeno aktivnost, kadar jo lahko svobodno izbere, jo obvlada in čuti, da je ob tem (ali pa kljub temu) povezan s pomembnimi drugimi.

V okviru naravoslovnih in tehničnih študijev bi tako veljalo prestrukturirati študijske aktivnosti in obveznosti v takšni smeri, da bi bolj spodbujale intrinzično motivacijo študentov, torej njihove lastne interese, radovednost in željo po novih izzivih v okviru študijskega dela. Na ta način bi bilo med temi študenti tudi manj hipertekmovalnosti, saj bi v primeru izvajanja aktivnosti zaradi lastnega interesa tudi bolj stremeli k lastnemu napred$\mathrm{ku}$, posledično pa bi bili bolj kot na premagovanje drugih osredotočeni na izboljšanje lastnih sposobnosti. Po drugi strani pa bi lahko študente družboslovja bolj spodbujali pri samouveljavljanju in samopromociji, predvsem v okviru iskanja službe in družbene umestitve. Poleg osebnostnega napredka je namreč - predvsem na trgu dela, kjer na nekaterih družboslovnih področjih prihaja do presežka kadra - pomembno tudi, da zna posameznik svoje sposobnosti pokazati in upravičiti, saj lahko drugi le na ta način v celoti spoznajo njegovo vrednost.

\section{Povezanost motivacije in ostalih psiholoških dimenzij zucnim uspehom}

Rezultati kažejo, da je povprečna ocena študentov nizko, a pomembno pozitivno povezana $\mathrm{z}$ motivacijo za izobraževanje, in sicer v večji meri z intrinzično kot ekstrinzično motivacijo. Višje ocene tako dosegajo študentje, ki imajo željo po izobraževanju in ki jih študij zanima ter jim prinaša zadovoljstvo. V okviru tega sta $\mathrm{z}$ učnim uspehom najbolj po- 
vezana motiv po védenju, torej izvajanje s študijem povezanih aktivnosti zaradi užitka in zadovoljstva, ki ga posamezniku dajeta učenje in raziskovanje ( $r=0.25 \mathrm{I}, p=0.000)$, ter identifikacija, ki se nanaša na pojmovanje učenja in študija kot za posameznika pomembnih dejavnosti, ki jih je sam izbral $(r=0.259, p=0.000)$. Z učnim uspehom sta prav tako povezana motiva po dosežkih $(r=0.192, p=0.000)$ in občutenju stimulacije $(r=0.150, p$ $=0.004$ ), torej vključevanje $\mathrm{v}$ študijske aktivnosti zaradi zadovoljstva ob doseganju uspeha ter doživljanja senzornih užitkov, estetskih doživetij, zabave in vznemirjenja. Povprečna ocena pa je negativno povezana $\mathrm{z}$ amotivacijo $(r=-0.143, p=0.007)$, kar pomeni, da ob odsotnosti motivacije za izobraževanje oziroma ciljev, povezanih s tem področjem, študent akademsko verjetno ne bo najbolj uspešen.

Povprečna ocena je prav tako pozitivno povezana tudi z nekaterimi področji motivacije za tekmovalnost, in sicer $\mathrm{z}$ izboljšanjem lastnih sposobnosti $(r=0.182, p=0.00 \mathrm{I})$ ter dobro opravljeno nalogo $(r=0.23 \mathrm{I}, p=0.000)$. Študentje, ki pri študiju dosegajo višje ocene, so torej bolj nagnjeni k tekmovalnosti z namenom, da bi izboljšali lastne sposobnosti in tako napredovali, pri čemer jim je pomembno tudi, da je naloga dobro opravljena.

Ugotovili smo tudi pozitivno povezanost med povprečno oceno in zadovoljenostjo vseh treh temeljnih psihičnih potreb. Študentje, ki so akademsko bolj uspešni, imajo močnejši občutek, da sami izbirajo svoje aktivnosti $(r=0.186, p=0.000)$ in so odgovorni zanje, da so pri delu učinkoviti $(r=0.202, p=0.000)$ in tudi da so bolj povezani z drugimi ljudmi $(r=0.138, p=0.009)$. Akademska uspešnost verjetno pripomore $\mathrm{k}$ boljšim odnosom $s$ profesorji, ostalimi študenti in tudi bližnjimi, saj ne povzroča frustracij, zaradi katerih bi se pri posamezniku sicer lahko pojavila negativna čustva in razpoloženja ter posledično konflikti v odnosih.

Povprečna ocena je bila pozitivno povezana tudi z dimenzijo kompetentnosti v okviru samospoštovanja $(r=0.165, p=0.002), s$ pogojenostjo samospoštovanja $(r=0.230, p$ $=0.000)$ in pozitivno emocionalnostjo $(r=0.121, p=0.023)$. To pomeni, da uspešnejši študenti doživljajo sebe kot učinkovite, sposobne ljudi, po drugi strani pa njihove ocene predstavljajo pomemben vir samospoštovanja: kadar dobijo dobro oceno, svoje sposobnosti vrednotijo višje kot v primeru, če se pri opravljanju izpitnih obveznosti slabo odrežejo.

Rezultati korelacijskih analiz torej kažejo, da so pri študiju uspešnejši študentje, ki jih študij zanima, učenje in raziskovanje pa jim nudita zadovoljstvo. K študijski uspešnosti prav tako pripomore tendenca $k$ izboljšanju lastnih sposobnosti in osebni rasti, pa tudi možnost izbire, občutek učinkovitosti in dobri odnosi z drugimi ljudmi v okviru študija. Ti rezultati so v nekaterih vidikih skladni z ugotovitvami drugih raziskovalcev. Mahyud- 
din, Elias in Noordin (2009) so ugotovili, da pri študentih obstaja pozitivna povezanost med storilnostno motivacijo in akademskim uspehom. Borges del Rosal, Hernandez-Jorge in Gonzalez Sierra (2012) prav tako navajajo, da je motivacija za izobraževanje poleg inteligentosti in učnih navad eden najmočnejših prediktorjev učnega uspeha pri učencih. Areepattamannil, Freeman in Klinger (20I I) so ugotovili, da so pri mladostnikih za učenje naravoslovja ključnega pomena motivacija za učenje oz. izobraževanje, samopodoba in metode poučevanja teh predmetov. V okviru motivacije so avtorji izpostavili zlasti intrinzično motivacijo, torej interes za določeno področje, medtem ko ekstrinzična motivacija ni imela večjega vpliva na učne dosežke. Kot pomembna prediktorja sta se izkazali tudi samopodoba in samoučinkovitost, in sicer predvsem v smislu zaznane sposobnosti za učenje in zaupanja vase, kar lahko povežemo z dimenzijo kompetentnosti tako v okviru samospoštovanja kot tudi na področju temeljnih psihičnih potreb.

\section{Povezanost med motivacijo, tekmovalnostjo in samospostovanjem}

Poleg korelacije med različnimi spremenljivkami in povprečno oceno smo preučili tudi povezanost med posameznimi konstrukti.

V okviru povezanosti med posameznimi področji oz. lestvicami rezultati kažejo, da obstaja dokaj močna povezanost med hipertekmovalnostjo in željo po zmagi $(r=0.644, p$ $=0.000$ ), kar je bilo pričakovano, saj izrazita želja po zmagi pravzaprav opredeljuje hipertekmovalnost. Hipertekmovalnost je pozitivno povezana tudi z motivacijo za vztrajanje in trudom, da bi se posameznik kar najbolje izkazal $(r=0.445, p=0.000)$. Motivacija za vztrajanje je pozitivno povezana tudi z osebno tekmovalnostjo, torej z željo po napredovanju in osebnostnem razvoju ter $\mathrm{z}$ odkrivanjem in preseganjem samega sebe $(r=0.572, p=$ 0.000). Po drugi strani hipertekmovalnost negativno korelira z doživljanjem zadovoljstva ob izboljšanju lastnih sposobnosti $(r=-0.386, p=0.000)$, saj hipertekmovalne osebe doživljajo največ ugodja ob zmagi oz. ko premagajo koga drugega, medtem ko jim lastni napredek ni tako pomemben. Hipertekmovalnost pa je povezana tudi z nestabilnostjo samospoštovanja $(r=0.425, p=0.000)$, saj pogosto odraža nizko ali krhko samospoštovanje, $\mathrm{ki}$ ob zmagi za kratek čas naraste.

V okviru samospoštovanja se samougajanje pozitivno povezuje z zadovoljenostjo vseh treh temeljnih potreb: po avtonomnosti $(r=0.521, p=0.000)$, kompetentnosti $(r=0.556$, $p=0.000)$ in povezanosti $(r=0.392, p=0.000)$. Podobno je tudi pri dimenziji kompetentnosti v okviru samospoštovanja, kjer korelacija $\mathrm{z}$ avtonomnostjo znaša $0.447(p=0.000)$, $s$ kompetentnostjo kot psihično potrebo $0.599(p=0.000)$ in $s$ povezanostjo $0.304(p=$ ○.०००). Študentje, ki imajo občutek, da sami izbirajo svoje aktivnosti, da so pri njih učin- 
koviti in povezani z ljudmi, ki so jim pomembni, imajo večji občutek socialne vrednosti in doživljajo sami sebe kot sposobno, učinkovito osebo, ki lahko vpliva na okolje in dosega svoje cilje. Tako samougajanje kot kompetentnost pa se negativno povezujeta $\mathrm{z}$ nestabilnostjo in pogojenostjo samospoštovanja ter z negativno emocionalnostjo. Študentje, pri katerih situacijski faktorji bolj vplivajo na trenutne spremembe v ocenjevanju sebe in pri katerih je samovrednotenje pogojeno $z$ doseganjem različnih (notranjih ali zunanjih) kriterijev, imajo nižji občutek socialne vrednosti in se počutijo manj učinkovite pri komunikaciji in manipuliranju z okoljem ter tudi pri doseganju lastnih ciljev. V povezavi s tem doživljajo tudi več negativnih čustev, npr. žalost, razočaranje, strah, jezo itd.

Pozitivna emocionalnost je pozitivno povezana $z$ vsemi področji intrinzične motivacije za izobraževanje, z zadovoljenostjo temeljnih psihičnih potreb, osebno tekmovalnostjo $(r=0.407, p=0.000)$, doživljanjem zadovoljstva zaradi dobro opravljene naloge $(r=$ $0.455, p=0.000)$ ter dimenzijo kompetentnosti v okviru samospoštovanja $(r=0.448, p=$ ○.000). Študentje, ki so si študij izbrali v skladu z lastnimi željami, so pri njem uspešni in imajo dobre odnose s kolegi ter profesorji, so bolj motivirani za opravljanje dejavnosti, povezanih s študijem. Študij jim prinaša zadovoljstvo in obenem omogoča, da napredujejo tudi na osebnem področju, kar se kaže v doživljanju pozitivnih čustev in razpoloženj - veselja, pričakovanja, ljubezni itd.

Negativna emocionalnost je pozitivno povezana z nestabilnostjo $(r=0.395, p=0.000)$ in pogojenostjo samospoštovanja $(r=0.477, p=0.000)$, po drugi strani pa negativno korelira z zadovoljenostjo temeljnih potreb. Ti rezultati so skladni z ugotovitvami Decija in Ryana (2000), ki navajata, da zadovoljenost temeljnih potreb ohranja in povečuje intrinzično motivacijo ter spodbuja ponotranjenje in integracijo ekstrinzične motivacije, vse to pa je povezano s pozitivnim doživljanjem, večjo učinkovitostjo posameznika in boljšim psihičnim zdravjem. Povezanost med nestabilnostjo samospoštovanja in negativno emocionalnostjo pa lahko razložimo z ugotovitvami Kernisa in njegovih sodelavcev (1998), ki so ugotovili, da se pri ljudeh z nestabilnim samospoštovanjem pri soočanju z vsakdanjimi ovirami ali stresnimi življenjskimi dogodki v večji meri pojavljajo simptomi depresivnosti.

Rezultati korelacijskih analiz so torej v splošnem skladni s teoretičnimi izhodišči, ki predpostavljajo, da zadovoljenost temeljnih psihičnih potreb po avtonomnosti, kompetentnosti in povezanosti povečuje in ohranja intrinzično motivacijo ter da se nezadovoljenost teh potreb kaže v amotivaciji ter slabšem psihičnem funkcioniranju, slabši učinkovitosti in nižji ravni psihičnega blagostanja pri posamezniku. Primerjave v prejšnjih poglavjih kažejo, da so študentje družboslovnih in humanističnih smeri bolj motivirani 
za študij, tako z vidika notranjih kot zunanjih motivacijskih sil, medtem ko se pri študentih naravoslovnih in tehničnih ved pogosteje pojavljajo amotivacijska stanja. Pri tej skupini študentov bi bilo torej potrebno delati v smeri povečevanja motivacije, in sicer predvsem intrinzične, saj so te oblike motivacije tesno prepletene tudi z drugimi vidiki optimalnega psihičnega delovanja - samospoštovanjem, doživljanjem pozitivnih čustev in razpoloženj itd. Da bi spodbudili študente k vpisu na naravoslovne in tehnične študije, pa bi bilo potrebno razvijati interes za ta področja že pri dijakih: poleg vsebine naravoslovnih predmetov bi bilo potrebno poudarjati tudi psihološke vidike učenja, raziskovanja in radovednosti ter v okviru poučevanja ustvariti okolje, ki bi dijakom omogočalo izbiro in vsaj določeno mero svobodnega odločanja, v katerem bi dijaki prejemali konstruktivne povratne informacije, vezane na kompetentnost (ne na zunanje določene norme), ter v katerem bi se dijaki počutili sprejete in cenjene. Poučevanje z ozirom na temeljne potrebe dijakov bi tako ustvarilo boljše pogoje za povišanje intrinzične motivacije že v okviru srednješolskega izobraževanja, posledično pa tudi kasneje, v času študija in opravljanja poklica.

\section{Zaključki}

Namen raziskave je bil ugotoviti povezanost med motivacijo za izobraževanje, tekmovalnostnimi naravnanostmi in različnimi področji samopodobe. Rezultati so pokazali, da na teh področjih med študenti obstajajo nekatere pomembne razlike glede na spol študentov in smer študija. V okviru povezanosti med spremenljivkami smo ugotovili pomembne korelacije med povprečno oceno in nekaterimi področji motivacije za izobraževanje in tekmovanje ter zadovoljenostjo temeljnih psihičnih potreb. Pokazale so se tudi pomembne povezave med posameznimi področji, na primer med motivacijo za tekmovanje in hipertekmovalnostjo oziroma osebno tekmovalnostjo, med samospoštovanjem in zadovoljenostjo temeljnih psihičnih potreb itd.

$\mathrm{Na}$ osnovi dobljenih rezultatov lahko zaključimo, da ima v okviru motivacije za izobraževanje pomembno vlogo predvsem intrinzična motivacija, ki je povezana s pozitivnim doživljanjem (zadovoljenostjo temeljnih psihičnih potreb, pozitivno emocionalnostjo in samospoštovanjem) ter tudi akademsko uspešnostjo študentov. Glede tekmovalnosti rezultati študije kažejo, da se intrinzična motivacija bolj povezuje z osebno tekmovalnostjo, ekstrinzična pa bolj s hipertekmovalnostjo. Študentje so bili v povprečju sicer najbolj motivirani za izboljšanje lastnih sposobnosti in dobro opravljeno nalogo, manj pa jih žene želja po zmagi.

Ugotovitve naše raziskave so uporabne predvsem kot načela za oblikovanje študijskega procesa, ki naj bo naravnan $\mathrm{v}$ smeri spodbujanja intrinzične motivacije in tekmoval- 
nosti v smislu osebnega razvoja posameznika. Tak način študija namreč omogoča večjo uspešnost in zadovoljstvo študentov pri izobraževanju, s tem pa tudi optimalen začetek poklicne poti.

\section{Literatura}

Ainley, M. D. (1994). Motivation and learning: Psychology and you. Victoria: Hawker Brownlow Education.

Anderman, E. M. in Maehr, M. L. (1994). Motivation and schooling in the middle grades. Review of Educational Research, 64 (2), 287-309.

Areepattamannil, S., Freeman, J. G. in Klinger, D. A. (2011). Influence of motivation, self-beliefs, and instructional practices on science achievement of adolescents in Canada. Social Psychology of Education, 14 (2), 233-259.

Baard, P. P., Deci, E. L. in Ryan, R. M. (2004). Intrinsic need satisfaction: A motivational basis of performance and well-being in two work settings. Journal of Applied Social Psychology, 34 (10), 2045-2068.

Baumeister, R. F. in Tice, D. M. (1985). Self-esteem and responses to success and failure: Subsequent performance and intrinsic motivation. Journal of Personality, 53 (3), $450-467$.

Baumgardner, A. H., Kaufman, C. M. in Levy, P. E. (1989). Regulating affect interpersonaly: When low self-esteem leads to greater enhancement. Journal of Personality and Social Psychology, 56, 907-921.

Borges del Rosal, A., Hernandez-Jorge, C. M. in Gonzalez Sierra, M. A. (2012). Achievement predictors in a secondary students' sample. Quality \& Quantity, 46, 16871697.

Chabrol, H., Rousseau, A. in Callahan, S. (2006). Preliminary results of a scale assessing instability of self-esteem. Canadian Journal of Behavioral Science, 38 (2), 136-141.

Connell, J. P. in Wellborn, J. G. (1990). Competence, autonomy and relatedness: A motivational analysis of self-system processes. V M. R. Gunnar in L. A. Sroufe (ur.), The Minnesota symposium on child psychology (str. 43-77). Hillsdale, NJ: Erlbaum.

Deci, E. L. (1975). Intrinsic motivation. New York: Plenum Press.

Deci, E. L., Koestner, R. in Ryan, R. M. (1999). A meta-analytic review of experiments examining the effects of extrinsic rewards on intrinsic motivation. Psychological Bulletin, 125 (6), 627-668.

Deci, E. L. in Ryan, R. M. (1985). Instrinic motivation and self-determination in human behavior. New York: Plenum Press. 
Deci, E. L. in Ryan, R. M. (1991). A motivational approach to self: Integration in personality. V R. Dienstbier (ur.), Nebraska symposium on motivation: Vol. 38. Perspectives on motivation (str. 237-288). Lincoln, NE: University of Nebraska Press.

Deci, E. L. in Ryan, R. M. (2000). The »what « and »why« of goal pursuits: Human needs and the self-determination of behavior. Psychological Inquiry, 11, 227-268.

Dweck, C. S. (1986). Motivational processes affecting learning. American Psychologist, 41 (10), 1040-1048.

Epstein, J. L. in McPartland, J. M. (1976). The concept and measurement of the quality of school life. American Educational Research Journal,13 (1), 15-30.

Franken, R. E. in Brown, D. J. (1995). Why do people like competition? The motivation for winning, putting forth effort, improving one's performance, performing well, being instrumental and expressing forcefull/aggressive behavior. Journal of Personality and Individual Differences, 19 (2), 175-184.

Gagné, M. (2003). The role of autonomy support and autonomy orientation in prosocial behavior engagement. Motivation and Emotion, 27, 199-223.

Greenier, K. D., Kernis, M. H., Whisenhunt, C. R., Waschull, S. B., Berry, A. J., Herlocker, C. E. in Abend, T. (1999). Individual differences in reactivity to daily events: Examining the roles of stability and level of self-esteem. Journal of Personality, 67, $185-208$.

Griffin-Pierson, S. (1990). The Competitiveness Questionnaire: A Measure of two components of competitiveness. Measurement and Evaluation in Counseling and Development, 23, 108-115.

Grolnick, W. S., Deci, E. L. in Ryan, R. M. (1997). Internalization within the family: The selfdetermination perspective. V J. E. Grusec in L. Kuczynski (ur.), Parenting and children's internalization of values: A handbook of contemporary theory (str. 135161). New York: Wiley.

Grolnick, W. S. in Ryan, R. M. (1987). Autonomy in children's learning: An experimental and individual difference investigation. Journal of Personality and Social Psychology, 52, 890-898.

Harter, S. (1981). The new self-report scale of intrinsic versus extrinsic orientation in the classroom: Motivational and informational components. Developmental Psychology, $17,300-312$.

Hidi, S. (2000). An interest researcher's perspective: The effects of extrinsic and intrinsic factors on motivation. New York: Academic Press. 
Hidi, S. in Harackiewicz, J. M. (2000). Motivating the academically unmotivated: A critical issue for 21st century. Review of Educational Research, 70 (2), 151-179.

Ilardi, B. C., Leone, D., Kasser, T. in Ryan, R. M. (1993). Employee and supervisor ratings of motivation: Main effects and discrepancies associated with job satisfaction and adjustment in a factory setting. Journal of Applied Social Psychology, 23, 1789-1805.

Kernis, M. H. in Goldman, B. M. (2005). Stability and variability in self-concept and self-esteem. V M. R. Leary in J. P. Tangney (ur.), Handbook of Self and Identity (str. 106-127). New York: The Guilford Press.

Kernis, M. H. in Paradise, A. W. (2002). Differentiating between fragile and secure forms of high self-esteem. V E. L. Deci in R. M. Ryan (ur.), Handbook of self-determination research (str. 339-360). Rochester, NY: University of Rochester Press.

Kernis, M. H., Whisenhunt, C. R., Waschull, S. B., Greenier, K. D., Berry, A. J., Herlocker, C. E. in Anderson, C. A. (1998). Multiple facets of self-esteem and their relations to depressive symptoms. Personality and Social Psychology Bulletin, 24, 657-668.

Kernis, M. H., Paradise, A. W., Whitaker, D., Wheatman, S. in Goldman, B. (2000). Master of one's psychological domain? Not likely if one's self-esteem is unstable. Personality and Social Psychology Bulletin, 26, 1297-1305.

Kobal, D. (2000). Temeljni vidiki samopodobe. Ljubljana: Pedagoški inštitut.

Kobal Grum, D. in Avsec, A. (2007). Samospoštovanje. V A. Avsec (ur.), Psihodiagnostika osebnosti (str. 93-120). Ljubljana: Filozofska fakulteta, Oddelek za psihologijo.

Kobal Grum, D., Kolenc, J., Žalec, B. in Lebarič, N. (2005). Sodobni pristopi k motivaciji in tekmovalnosti $v$ modelih samopodobe: medkulturna študija: zaključno poročilo o rezultatih raziskovalnega projekta. Ljubljana: Pedagoški inštitut.

Krapp, A. (1998). Interest, motivation and learning: An educational-psychological perspective. European Journal of Psychology of Education, 14, 23-40.

Mahyuddin, R., Elias, H. in Noordin, N. (2009). Emotional intelligence, achievement motivation and academic achievement among students of the public and private higher institutions. The International Journal of Diversity in Organisations, Communities and Nations, 9 (4), 135-144.

Markus, H. R. in Kunda, Z. (1986). Stability and malleability of the self-concept. Journal of Personality and Social Psychology, 51, 858-866.

Marsh, H. W., Owens, L., Myers, M. R. in Smith, I. D. (1989). The transition from singe-sex to co-educational high schools: Teacher perceptions, academic achievement, and self-concept. British Journal of Educational Psychology, 59, 155-173. 
McInerney, D. M., Roche, L., McInerney, V. in Marsh, H. W. (1997). Cultural perspectives on school motivation: The relevance and application of goal theory. American Educational Research Journal, 34, 207-236.

McInerney, D. M., Yeung, A. S. in McInerney, V. (2000). The meaning of school motivation: Multidimenzional and hierarchical perspectives. 81st annual meeting of the American educational research association. New Orleans.

McMenniman, M. (1989). Motivation to learn. V P. Langford (ur.), Educational psychology: An Australian perspective (str. 215-237). Melbourne: Longman Cheshire.

McMullin, J. A. in Cairney, J. (2004). Self-esteem and the intersection of age, class, and gender. Journal of Aging Studies, 18, 75-90.

Miserandino, M. (1996). Children who do well in school: Individual differences in perceived competence and autonomy in above-average children. Journal of Educational Psychology, 88, 203-214.

Musek, J. (1985). Model referenčnega jaza. Ljubljana: Društvo psihologov Slovenije.

Musek, J. (2005). Psihološke in kognitivne študije osebnosti. Ljubljana: Znanstveni inštitut Filozofske fakultete.

Niemiec, C. P. in Ryan, R. M. (2009). Autonomy, competence, and relatedness in the classroom: Applying self-determination theory to educational practice. Theory and Research in Education, 7, 133-144.

Paradise, A. W. in Kernis, M. H. (1999). Development of the Contingent Self-Esteem Scale. Unpublished scale, University of Georgia.

Pintrich, P. R. in Schunk, D. H. (1996). Motivation in education: Theory, research, and applications. Englewood Cliffs: Prentice Hall.

Race, P. (1998). Teaching: Creating a thirst for learning? V S. Brown (ur.), Motivating students (str. 47-58). London: Kogan Page.

Reeve, J. in Deci, E. L. (1996). Elements within the competitive situation that affect intrinsic motivation. Personality and Social Psychology Bulletin, 22, 24-33.

Renninger, K. A. (1998). Individual interest and its implications for understanding intrinsic motivation. V C. Sansone in J. M. Harackiewicz (ur.), Intrinsic motivation: Controversies and new directions. New York: Academic Press.

Riskind, J. H. in Wilson, D. W. (1982). Interpersonal attraction for the competitive person: Unscrambling the competition paradox. Journal of Applied Social Psychology, 12 (6), 444-452.

Rosenberg, M. (1989). Society and the adolescent self-image (Revised edition). Middletown, CT, England: Wesleyan University Press. 
Ryan, R. M. in Connell, J. P. (1989). Perceived locus of causality and internalization: Examining reasons for acting in two domains. Journal of Personality and Social Psychology, 57, 749-761.

Ryan, R. M. in Deci, E. L. (2000). Intrinsic and extrinsic motivations: classic definitions and new directions. Contemporary Educational Psychology, 25, 54-67.

Ryan, R. M., Deci, E. L. in Grolnick, W. S. (1995). Autonomy, relatedness, and tle self: Their relation to development and psychopathology. V D. Cicchetti in D. J. Cohen (ur.), Developmental psychopathology Vol. 1 (str. 618-655). New York: Wiley.

Ryan, R. M. in Grolnick, W. S. (1986). Origins and pawns in the classroom: Self-report and projective assessments of individual differences in children's perceptions. Journal of Personality and Social Psychology, 50, 550-558.

Ryckman, R. M., Hammer, M., Kaczor, L. M. in Gold, J. A. (1990). Construction of a hypercompetitive attitude scale. Journal of Personality Assessment, 55, 630-639.

Ryckman, R. M., Hammer, M., Kaczor, L. M. in Gold, J. A. (1996). Construction of a personal development competitive attitude scale. Journal of Personality Assessment, 66 (2), 374-385.

Schiefele, U. in Krapp, A. (1996). Topic interest and free recall of expository text. Learning and Individual Defferences, 8, 141-160.

Shavelson, R. J., Hubner, J. J. in Stanton, G. C. (1976). Validation of construct interpretations. Review of Educational Research, 46, 407-411.

Sheldon, K. M. in Kasser, T. (1995). Coherence and congruence: Two aspects of personality integration. Journal of Personality and Social Psychology, 68, 531-543.

Smither, R. in Houston, J. M. (1992) The nature of competitiveness: The development and validation of the competitiveness index. Educational and Psychological Measurement, 52, 407-418.

Tafarodi, R. W. in Swann, W. B., Jr. (2001). Two-dimensional self-esteem: Theory and measurement. Personality and Individual Differences, 31, 653-673.

Tauer, J. M. in Harackiewicz, J. M. (2004). The effects of cooperation and competition on intrinsic motivation and performance. Journal of Personality and Social Psychology, $86(6), 849-861$.

Tripathi, K. N. (1992). Competition and intrinsic motivation. The Journal of Social Psychology, 132 (6), 709-715.

Vallerand, R. J. in Bissonnette, R. (1992). Intrinsic, extrinsic, and amotivational styles as predictors of behavior: A prospective study. Journal of Personality, 60, 599-620. 
Vallerand, R. J., Blais, M. R., Brière, N. M. in Pelletier, L. G. (1989). Construction et validation de l'Echelle de motivation en education (EME). Canadian Journal of Behavioral Sciences, 21, 323-349.

Vallerand, R. J., Pelletier, L. G., Blais, M. R., Brière, N. M., Senécal, C. B. in Vallières, E. F. (1992). The academic motivation scale: A measure of intrinsic, extrinsic, and amotivation in education. Educational and Psychological Measurement, 52, 1003-1017.

Waschull, S. B. in Kernis, M. H. (1996). Level and stability of self-esteem as predictors of children's intrinsic motivation and reasons for anger. Personality and Social Psychology Bulletin, 22, 4-13.

Watkins, D. in Akande, A. (1994). Approaches to learning of Nigerian secondary school children: Emic and etic perspectives. International Journal of Psychology, 29 (2), 165182.

Watson, D., Clark, L. A. in Tellegen, A. (1988). Development and validation of brief measures of positive and negative affect: The PANAS scales. Journal of Personality and Social Psychology, 54, 1063-1070.

Williams, G. C. in Deci, E. L. (1996). Internalization of biopsychosocial values by medical students: A test of self-determination theory. Journal of Personality and Social Psychology, 70, 767-779.

Yeung, N. T. Y. in Yeung, A. S. (2001). Does school motivation change over secondary school years? AARE 2001. Fremantle, Australia: The University of Notre Dame.

Zupančič, M., Kavčič, T. in Fekonja, U. (2004). Razvojne naloge v odraslosti. V L. Marjanovič Umek in M. Zupančič (ur.), Razvojna psihologija (str. 634-654). Ljubljana: Znanstvenoraziskovalni inštitut Filozofske fakultete.

Zupančič, M. in Svetina, M. (2004). Socialni razvoj v mladostništvu. V L. Marjanovič Umek in M. Zupančič (ur.), Razvojna psihologija (str. 589-611). Ljubljana: Znanstvenoraziskovalni inštitut Filozofske fakultete. 



\section{Motivacija v izobraževanju odraslih}

\section{Marko Radovan, Sabina Jelenc Krašovec in Sonja Kump'}

Raziskovanje motivacije ima $\mathrm{v}$ andragogiki pomembno vlogo in dolgo tradicijo, saj je za izobraževalce poznavanje razlogov, zaradi katerih se odrasli udeležujejo izobraževanja, pomemben kazalnik, ki ga upoštevajo pri oblikovanju in izpeljavi izobraževalnih programov. V andragogiki se je uveljavilo kar nekaj motivacijskih teorij, ki so poskušale opisati razloge, zaradi katerih se odrasli odločijo za izobraževanje. Prve pomembne raziskave na tem področju je že v šestdesetih letih dvajsetega stoletja opravil Houle (196I), ki je pri odraslih ugotovil tri učne usmeritve: usmeritev $\mathrm{k}$ ciljem, usmeritev $\mathrm{k}$ dejavnosti in usmeritev k učenju. Tough (1979) pa je menil, da se odrasli izobraževanja udeležujejo iz zelo različnih vzrokov (višji dohodek, spoznavanje drugih itn.), kar kaže na to, da motivacija za udeležbo ni enovit pojav, ampak je sestavljen iz različnih življenjskih ali poklicnih vzgibov in položajev, ki vplivajo na odločitev za udeležbo v izobraževanju odraslih. Pomemben vidik motivacije odraslih je tudi motivacija med učenjem. V tem primeru si predvsem pomagamo z razumevanjem notranjih oz. psiholoških in tudi zunanjih oz. socioloških dejavnikov.

V nadaljevanju bomo predstavili glavne motivacijske dejavnike, ki odrasle spodbujajo $\mathrm{k}$ učenju in povečujejo njihovo motivacijo med učenjem. Poleg predstavitev nekaterih psiholoških teorij, ki obravnavajo to tematiko, bomo predstavili še »osebni izobraževalni načrt«, njegova teoretična izhodišča, in sicer kot orodje, s katerim lahko v izobraževalnih ustanovah spodbujajo angažiranost in vztrajnost udeležencev.

1 Vsi: Univerza v Ljubljani, Filozofska fakulteta, Oddelek za pedagogiko in andragogiko. 
Notranji in zunanji vidiki motivacije

$\mathrm{V}$ preteklosti so poskušali opisati pomen posameznega dejavnika predvsem pod vplivom kognitivne in humanistične psihologije, pri čemer so v razumevanje in razlago pripravljenosti posameznika za izobraževanje vključevali sociološke dejavnike. S tem razmislekom je svoje motivacijske modele razvijalo precej avtorjev (Miller, 1967; Rubenson, 1987; Cross, 1981). Miller (1967) je skušal združiti teorijo Maslowa in Lewina, da bi razložil povezanost posameznikovih potreb, aspiracij in vrednot s socialno-ekonomskimi razmerami, v katerih živi posameznik. Poudaril je pozitivne in negativne »sile«, ki izvirajo iz teh razmer, in njihov relativni pomen za posameznikovo pripravljenost za izobraževanje. Lewinov vpliv najdemo tudi v Rubensonovi (1987) teoriji, v kateri razlaga motivacijo odraslih za izobraževanje s pomočjo teorije pričakovanj. Poglavitni dejavniki v tej teoriji so posameznikova pričakovanja in vrednote, ki jih je dopolnil še z dejavniki okolja, kot so socializacija, stališča referenčnih skupin in socialno-ekonomske možnosti (Rubenson, 1987). Naslednja bolj znana motivacijska teorija motivacije odraslih za učenje in izobraževanje je »teorija skladnosti« (angl. »Congruence theory«) Rogerja Boshierja (1973). Po tej teoriji bo posameznik sodeloval v izobraževanju, kadar bo dosežena neka kongruenca ali skladnost med posameznikovim samozaznavanjem (svojih potreb, ciljev, sebe kot učenca ipd.) in značilnostmi izobraževalnega okolja.

Med novejše poglede na motivacijo odraslih za učenje prištevamo model, ki ga oblikuje Wlodkowski (2008) in ki poudarja pomen občutka vključenosti potreb, pozitivnih stališč, pozitivnega vrednotenja učne snovi ter občutka kompetentnosti. Vsem tem potrebam mora biti zadoščeno, da bi se razvila ustrezna raven motivacije, ki bi vodila k udeležbi v izobraževalni program ali krepila vztrajanje v njem.

Med tistimi psihološkimi dejavniki, ki še posebej spodbujajo motivacijo za učenje in so neposredno povezani tudi s cilji oblikovanja osebnega izobraževalnega načrta, moramo omeniti predvsem cilje - njihove značilnosti in vpliv na motivacijo. Cilji vplivajo na motivacijo z osredotočanjem posameznikove pozornosti na neskladje med njihovo zdajšnjo ravnjo dosežkov in idealno ravnjo dosežkov. Austin in Vancouver (1996) ponujata dokaj široko definicijo ciljev, po kateri so cilji neke notranje predstave želenih stanj. Te »notranje predstave« variirajo glede specifičnosti od manj do bolj kompleksnih ciljev.

Locke in Latham (1990) opišeta cilje kot predmet, dejavnost ali pojav, h kateremu je usmerjena naša dejavnost in s katerim zadovoljimo potrebo. Avtorja naštevata štiri najpomembnejše razloge, zakaj postavljanje ciljev povečuje uspešnost: (I) cilji usmerjajo našo pozornost in prizadevanje $\mathrm{k}$ dejavnostim, ki so pomembne za doseganje cilja; (2) cilji da- 
jejo vedenju energijo, saj se prizadevanje povečuje toliko časa, dokler se cilj ne doseže; (3) cilji vplivajo na vztrajnost; (4) cilji pospešujejo razvoj novih strategij, kadar stare niso več primerne. Jasno je, da oseba, ki ima cilje, navadno dosega boljše uspehe kakor oseba brez njih, vendar pa je pomembno tudi, kakšne cilje si postavi. Najpomembnejše so naslednje dimenzije ciljev: specifičnost, zahtevnost, povratna informacija o napredovanju, časovna oddaljenost ciljev in avtonomnost pri postavljanju ciljev.

\section{Razumevanje izobraževalnih ovir}

Omenili smo že, da je za ustrezno razumevanje dejavnikov, ki vplivajo na udeležbo v izobraževanju, potrebno tudi poznavanje ovir, ki odraslim to udeležbo preprečujejo. Jasno je, da mora biti oseba, če se sploh udeleži izobraževanja, pripravljena in na neki način motivirana, da se bo udeležila izobraževalnega programa, ponudba programov mora biti ustrezna in udeležba ne sme biti omejena z pogoji, ki jo otežujejo, če že ne onemogočajo (npr. denar, neprimeren čas, prevelika oddaljenost od doma). Če tem pogojem ni zadoščeno, se verjetnost udeležbe seveda zelo zmanjša. Poleg tega smo že omenili, da bolj ko je oseba motivirana za udeležbo, več verjetnosti je, da bo premagala ovire na poti k udeležbi v programu. Oglejmo si torej nekaj ugotovitev glede raziskovanja udeležbe v izobraževanju.

Med najpomembnejše prispevke k razumevanju ovir sodi delo P. K. Cross (198I), ki je povzela spoznanja Johnstona in Rivere ter Carpa in sodelavcev ter oblikovala svojo klasifikacijo ovir. Ovire je razvrstila v tri skupine: situacijske, institucijske in dispozicijske. Tako kot pri Johnstonu in Riveri je za situacijske ovire značilno, da izhajajo iz posameznikovega trenutnega položaja in se izražajo $\mathrm{v}$ pomanjkanju časa, denarja, oddaljenosti kraja izobraževanja itn.; dispozicijske ovire pa se povezujejo s posameznikovimi psihosocialnimi značilnostmi, kot so stališča, samopodoba, prepričanja o sposobnosti itn. Cross (198I) je dodala še novo kategorijo ovir, in sicer institucionalne ovire. Ta skupina ovir je sestavljena iz vseh praks in postopkov, ki odvračajo odrasle od udeležbe v izobraževalnih dejavnostih. Nova skupina ovir je pomembna, saj včasih tudi institucije same z neustrezno izobraževalno ponudbo, nerealističnimi zahtevami programa ali neprilagojeno organizacijo izobraževanja onemogočajo udeležbo odraslih v programih izobraževanja in s tem prispevajo $\mathrm{k}$ problemu neudeležbe.

Po mnenju P. K. Cross je najpomembnejša skupina ovir situacijska in v njej pomanjkanje denarja in časa. To potrjujejo tudi vse starejše in novejše raziskave, ki so jih opravili na tem področju. Obenem pa je tudi opozorila, da je lahko pomembnost teh ovir povečana zaradi socializacije odgovorov, ki izraža metodološko pomanjkljivost anketnih raziskav. Pri večini anketnih raziskav so ovire navadno ugotavljali z anketnimi vprašanji ali struk- 
turiranimi intervjuji, v katerih so anketirance vprašali, zakaj se niso udeležili izobraževanja. Ker se izobraževanje večinoma opisuje kot pozitivna in zaželena dejavnost - če že ne kar odgovornost -, anketiranci pogosto odgovorijo s socialno zaželenimi razlogi, ki naj bi pojasnili njihovo neudeležbo v izobraževanju, namesto da bi odkrili svoje prave razloge.

Iz opisa motivacijskega delovanja ciljev in izobraževalnih ovir lahko zelo hitro potegnemo vzporednice s procesom oblikovanja osebnega izobraževalnega načrta. Vpeljava osebnega izobraževalnega načrta v izobraževanje odraslih ima po eni strani izvore v psiholoških teorijah motivacije, po drugi pa tudi v samih andragoških načelih, ki v ospredje postavljajo av tonomnost, sodelovanje in aktivno vlogo odraslega pri svojem izobraževanju.

Razumevanje motivacijske vloge osebnega izobraževalnega načrta ne bi bilo popolno, če ne bi omenili dveh psiholoških motivacijskih teorij, ki naše delovanje razumeta predvsem na podlagi avtonomije in nadzora: teorijo samoodločanja (Deci in Ryan, 20I2) in teorijo samoregulacijskega učenja (Zimmerman, 2002).

\section{Teorija samoodločanja}

Teorijo samoodločanja (angl. self-determination theory) je razvil Edward L. Deci s sodelavci (Deci in Ryan, 1985, 2012). Po njihovem prepričanju izvira notranja motivacija iz dveh primarnih potreb posameznika: potrebe po kompetentnosti in potrebe po nadzoru nad svojim okoljem (Deci in Ryan, 1985). Pri tem poudarjata predvsem vpliv avtonomnega nasproti kontrolnemu kontekstu na posameznikovo notranjo motivacijo, ki jo zato definirata kot »človekovo potrebo po zaznavanju kompetentnosti in avtonomnosti lastnih dejanj v odnosu do okolja« (ibid.: 27). Avtorja poudarjata, da avtonomija ne pomeni popolne neodvisnosti od zunanjega sveta, temveč je definirana z občutkom lastne volje, ki spremlja katero koli posameznikovo dejanje ne glede na to, ali je avtonomno ali pa vir zahtev v socialnem okolju. Posameznik je notranje motiviran takrat, ko deluje v skladu s svojimi odločitvami in izbirami. To pomeni, da bo posameznik notranje motiviran, ko bo imel občutek kontrole nad izbiro lastnega delovanja in možnost fleksibilne uravnavanja dejavnosti. Primer: posameznik ima lahko prirojeno potrebo po učenju, manifestira pa jo $\mathrm{z}$ branjem knjig. Notranji motivaciji bo zadovoljeno, ko se posameznik odloči, katero knjigo bo prebral in kdaj bo to storil. Notranja motiviranost posameznika je zelo povezana tudi z občutkom kompetentnosti pri izpolnjevanju nalog, aktivnosti ipd. Izzivi naj bi bili posamezniku dosegljivi. Če so prelahki, bo poiskal zahtevnejše; če so prezahtevni, pa se utegne njegov trud zmanjšati. Notranja motivacija se zmanjša, če posameznik nima možnosti uresničevati samoodločanja. Posameznik si želi izkusiti odgovornost za svoja dejanja in svobodo pri izbiranju. 
Deci in sodelavci (1985) so opozorili na pomembno dimenzijo spodbujanja našega vedenja/motivacije, ki se lahko razteza od prisile do avtonomije posameznika. Oblike ojačenja, ki dopuščajo več avtonomije, so še posebej primerne za izobraževalne smotre. Deci je prepričan, da bi morali v izobraževanju zmanjševati nadzor in spodbujati avtonomnost učečih se ter podpirati njihovo samostojnost pri odločanju. Povezava med notranjo motivacijo in vlogo osebnega izobraževalnega načrta pri tem je iz tega primera več kot očitna.

\section{Teorija samoregulacijskega učenja}

Tudi notranje motivirani udeleženci imajo lahko težave pri upravljanju svojega učenja. $S$ tega vidika je pomembna še druga dimenzija razumevanja motivacije: sposobnost, da razvijejo učinkovite samoregulacijske strategije za uspešno učenje. V najširšem pomenu besede samoregulacijo pri učenju opišemo kot stopnjo metakognitivne, motivacijske in vedenjske dejavnosti v lastnem učnem procesu (Zimmerman, 2002). Za učeče se, ki dejavno uravnavajo svoje učenje, je značilno, da uporabljajo različne kognitivne in metakognitivne strategije, sistematično usmerjene k doseganju učnih ciljev. Uporabljajo tudi strategije, s katerimi uravnavajo druge vire učenja, kot so prilagoditev nekaterih vidikov fizičnega okolja in organiziranosti časa za učenje, tako da bi le-to postalo kar se da učinkovito. Pomembna sestavina samoregulacijskega učenja so še strategije, ki se nanašajo na uravnavanje učenja in učnega okolja. V to skupino strategij sodijo npr. organizacija časa, uravnavanje truda in ureditev prostora za učenje (Pintrich in Garcia, I99I).

Ugotovili so, da učeči se, ki zavestno ne uravnavajo svojega učenja, uporabljajo manj kognitivnih in metakognitivnih strategij, imajo negativna mnenja o lastni učinkovitosti in so bolj zunanje motivirani za učenje, pri doseganju ciljev pa so manj vztrajni (Zimmerman, 2002; Pintrich in Garcia, 1991). Raziskave, opravljene v zadnjih dvajsetih letih, so pokazale pomembno povezanost med učnim uspehom in samouravnavanjem učenja pri osnovno-, srednje-, višje- in visokošolcih in tudi pri odraslih udeležencih (Corno in Mandinach, 1983 ; Pintrich, 1989; Pintrich in De Groot, 1990; Zimmerman in Martinez-Pons, 1990).

Model samoregulacijskega učenja, ki ga razvija Barry Zimmerman, temelji na Bandurovi socialnokognitivni teoriji (Zimmerman, 2002), v kateri je samouravnavanje opredeljeno kot zmožnost nadzora nad lastnim vedenjem, ki je podlaga posameznikove osebnosti, in predvideva tri korake:

- $\quad$ samoopazovanje - opazujemo sebe in svoje vedenje;

- $\quad$ vrednotenje - kar vidimo, primerjamo z določenim standardom ali merilom; 
- $\quad$ samoodzivanje - če smo se po primerjavi z nekim standardom, dobro izkaza-

li, se nagradimo, kadar smo slabi, se grajamo (Bandura, 1997).

Po Zimmermanu (2002) je samoregulacijski proces po svoji naravi cikličen in izvira iz misli, občutkov in načrtovanega vedenja, ki so usmerjeni v doseganje postavljenih ciljev. Povedano drugače: informacije, ki jih dobimo pri učnih izkušnjah, so uporabne za prilagajanje ciljem, izbiranje strategij in prizadevanje. Ta definicija se razlikuje tudi od definicij, ki opišejo samouravnavanje učenja z metakognitivnega zornega kota ter poudarjajo znanje in deduktivno mišljenje pri izbiri učne strategije. Čeprav ima metakognicija pomembno vlogo, je samouravnavanje odvisno predvsem od prepričanj o sebi in posameznikovih čustvenih odzivov. Krožni model samoregulativnega učenja je sestavljen iz treh faz, v katerih oseba načrtuje, izvaja in vrednosti svoje učenje (Slika I5).

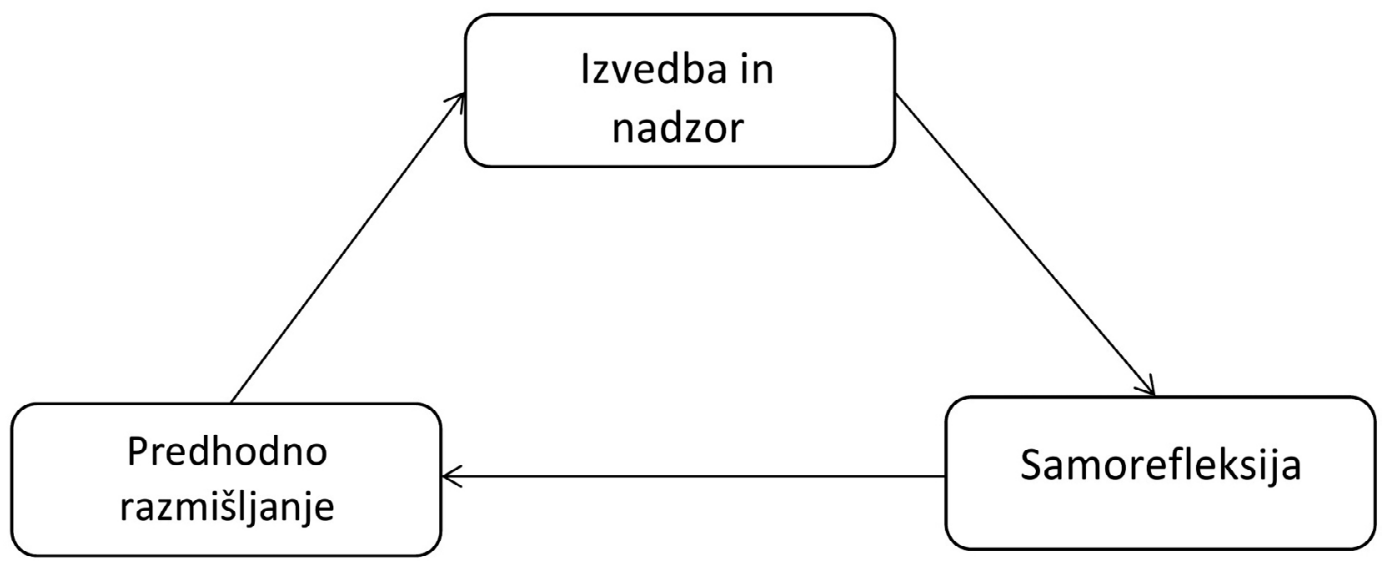

Slika I5: Socialno-kognitivni model samoregulacijskega učenja (Zimmerman, 2002: 67)

Faza predhodnega razmišljanja zadeva procese in prepričanja, ki so časovno pred učenjem in so nekakšna priprava na učenje. Identificirani sta dve vrsti procesov: prva so procesi, ki se nanašajo na analizo naloge. Druga faza, faza izpeljave in nadzora, vsebuje procese, ki potekajo med učenjem in pripomorejo učencem $\mathrm{k}$ boljši osredotočenosti na nalogo in optimalno izvedbo le-te, npr: strategije pri nalogi pomagajo pri učenju z zoženjem naloge na njene bistvene sestavine in pri smiselnejši organizaciji. Zadnja faza, t. i. faza samorefleksije, vsebuje procese po učenju, kot so samovrednotenje in ocenjevanje dosežkov Zimmerman, 2002). 
Teorija samoregulacijskega učenja poudarja, da mora biti posameznik ne samo motiviran, da bo uspešno zaključil svoje učenje, ampak mora tudi poznati načine in strategie, kako bo svoje cilje dosegel.

\section{Osebni izobraževalni načrt in andragoška teorija}

Vključevanje osebnega izobraževalnega načrta (OIN) kot pripomočka pri učenju v našem šolskem sistemu ni novost. Na tak ali drugačen način se ga je že v preteklosti uporabljalo v rednem (»mladinskem «) izobraževanju kot tudi izobraževanju odraslih, kjer so se razvijala podobna orodja $\mathrm{z}$ različnimi imeni (npr. »učna pogodba v izobraževanju odraslih«, »zbirna mapa«, »osebni list« in podobno). Kar je novo, je formalno ozadje tega orodja, ki se je z različnimi zakoni in podzakonskimi akti formaliziralo in postavilo kot obveznost za izobraževalce.

S. Klemenčič (2004) opredeljuje OIN v širšem in ožjem smislu. V širšem pomenu besede gre za dejavno odkrivanje poti načinov in možnosti za izobraževane, pri čemer mislimo na posameznikovo spoznavanje izobraževalnih možnosti in različnih metod in oblik, s katerimi lahko doseže svoje izobraževalne cilje. V ožjem smislu pa je OIN načrt izobraževanja ali učenja, ki je tako vsebinsko in ciljno-organizacijsko kot časovno prilagojen posamezniku (Klemenčič, 2004: I2).

Skladno z navedeno ožjo definicijo so OIN opredelili tudi Justinek idr. (2010: 9), in sicer kot orodje, s katerim posameznik:

- načrtuje svojo pot izobraževanja do poklica ob pomoči mentorja,

- izbere vsebine, raven zahtevnosti in načrtuje čas doseganja vmesnih ciljev in končnega cilja,

- evalvira vmesne dosežke in ugotavlja, kje na poti k cilju trenutno je,

- po potrebi spreminja oziroma prilagaja svoj načrt glede na zastavljen cilj,

- razvija odgovornost za svojo poklicno in osebnostno rast.

Osebni izobraževalni načrt je torej pripomoček, ki udeležencu izobraževanja omogoča prepoznavanje, načrtovanje in uresničevanje izobraževalnih ciljev, ki so v skladu z njegovimi potrebami, interesi in zmožnostmi.

Razvijanje podobnih orodij za pomoč oz. usmerjenje posameznika med učenjem ima v andragogiki sploh dolgo tradicijo, njihove izvore pa lahko poiščemo pri več avtorjih, najbolj neposredno pa izhaja iz koncepta »učnih pogodb « (angl. learning contracts), ki ga je v osemdesetih razvijal Malcolm S. Knowles (1975, I99I); pri tem je izhajal iz potrebe odraslih po samostojnosti pri učenju, upoštevanju izkušenj in drugih psiholoških potreb. 


\section{Samostojno učenje odraslih}

Področje, ki se je v okviru izobraževanja odraslih v zadnjih treh desetletjih najbolj razvijalo, je bilo področje samostojnega učenja (v Sloveniji poznanega tudi po imenom »usmerjeno samostojno učenje « in »samoizobraževanje «) - se pravi učenja, kjer odrasli sam vodi in usmerja svoje učenje. Čeprav se je v izobraževanju odraslih kot velika tema pojavilo šele v 1970- in 1980-tih, je ideja samostojnega učenja (tj. da odrasli sam nadzira potek svojega učenja) že zelo stara. Kulich (v Brockett in Hiemstra, I99I), na primer, v svojem zgodovinskem pregledu samostojnega učenja navaja primere zgodovinskih osebnosti, kot so Socrates, Aleksander Veliki, Cezar in Descartes. V andragogiki pa se je teorija samostojnega učenja utemeljila predvsem v delu Allena Tougha in raziskavah o učnih projektih odraslih (Tough, 1979). Tough se je pri svojem delu zelo opiral na raziskavo o motivacijskih usmeritvah odraslih, ki jo je opravil Houle (196I/I993). Houle je intervjuval 22 odraslih in ugotovil tri temeljne učne usmeritve: usmeritev $\mathrm{k}$ ciljem, usmeritev $\mathrm{k}$ dejavnosti in usmeritev $\mathrm{k}$ učenju (Houle, 1993: 14-15).

Tougha so navdahnili predvsem tisti odrasli, ki so se uvrstili v skupino »na učenje usmerjenih « udeležencev; to so bili torej tisti odrasli, pri katerih je učenje potekalo neprenehoma - ko so končali z enim učenjem, so nadaljevali z drugim. V svojem delu »Učni projekti odraslih« (Tough, 1979) je avtor raziskal pogostost in naravo tega »samo-načrtovanega « učenja na vzorcu 66 odraslih. Učni projekt je opredelil kot vrsto med seboj povezanih učnih epizod, ki trajajo skupaj najmanj sedem ur in so usmerjene k pridobivanju ali ohranjanju nekega znanja ali spretnosti (Tough, 1979: 7). Glavna ugotovitev raziskave je bila, da skoraj vsak človek v obdobju enega leta opravi vsaj en učni projekt in da so odrasli v vzorcu več kot dve tretjini vseh učnih dejavnosti načrtovali, izvajali in ocenjevali večinoma sami, pri ostalih pa jim je pri tem pomagal usposobljen strokovnjak. Številne ponovitve raziskave $\mathrm{z}$ različnimi vzorci odraslih so v veliki meri potrdile Toughove ugotovitve (gl. Brockett in Hiemstra, 1991).Veliko je bilo diskusij o tem, kaj pravzaprav sestavlja samostojno učenje. Avtorji, kot sta Tough (1979) in Knowles (1975), so večinoma poudarjali pomen samostojnega učenja $\mathrm{v}$ okviru sistematičnega procesa oblikovanja takšne dejavnosti. Knowles (1975) je npr. predlagal, da bi se izraz nanašal na proces, v katerem posameznik prevzame vodilno vlogo pri »prepoznavanju učnih potreb, oblikovanju učnih ciljev, prepoznavanju človeških in materialnih virov za učenje, izbiranju in izvajanju ustreznih strategij učenja in ocenjevanju rezultatov« (str. I8). Sčasoma so avtorji začeli presegati te, bolj deskriptivne, opise samostojnega učenja in začeli razpravljati o tem, kaj naj bi sploh bili cilji takega učenja (Brockett in Hiemstra, I99I), ter raziskovati osebnost- 
ne značilnosti odraslih, ki so pri samostojnem učenju uspešni (Candy, 1991), ali družbeni kontekst, v katerem tako učenje poteka (Brookfield, 1985).

Brockett in Hiemstra (199I) sta razvila "Model usmerjenosti k osebni odgovornosti” (angl. Personal Responsibility Orientation model; PRO model), v katerem se »samostojno učenje« uporablja kot krovni pojem, ki je sestavljen iz dveh povezanih razsežnosti: samostojnega učenja, ki poudarja elemente procesa učenja - večinoma tako, kot ga je opredelil Knowles -, in samostojnega učenja, ki se osredotoča na notranje značilnosti posameznika, kot »nagnjenost $\mathrm{k}$ prevzemanju odgovornosti za učenje (Brockett in Hiemstra,1991: 28-29). PRO model priznava tudi pomen družbenega konteksta, v katerem učenje poteka. Drugi poskus, s katerim bi se povečalo naše razumevanje samostojnega učenja, je mogoče najti v delu Candyja (I99I), ki je pristopil k razumevanju samostojnega učenja s konstruktivističnega vidika. Candy razlikuje med samostojnostjo pri učenju kot »procesom ali metodo izobraževanja « in kot »ciljem ali izidom«(Candy, I99I: 19). Samostojnost pri učenju je razdelil na dve področji: nadzor učečega se, v katerem ta ohranja primarno odgovornost za učenje, in »avto-didaktičnost «, v katerem ni prisotnega učitelja in kjer lahko učenje poteka tudi priložnostno.

\section{Osebni izobraževalni načrt kot učna metoda ali ǚni pripomoček}

Uporaba osebnega izobraževalnega načrta in podobnih orodij je v izobraževanju odraslih različno definirana. Nekateri avtorji ta pripomoček definirajo kot učno metodo (O’Donnell in Cafferella, I991: 133) in se pri tem osredotočajo predvsem na njegovo uporabo v formalnem izobraževanju odraslih. Učna pogodba je v tem smislu razumljena predvsem kot sredstvo individualizacije procesa izobraževanja. Uporaba termina »pogodba« daje dogovoru med udeležencem izobraževanja in učiteljem bolj obvezujoč prizvok - ta zaveza velja za oba, tako za udeleženca kot učitelja.

Knowles (1975) je učne pogodbe razvijal kot pripomoček za spodbujanje in razvoj samostojnega učenja in pri tem predvidel pet korakov:

a. določanje učnih potreb,

b. določanje učnih virov in strategij,

c. ugotavljanje doseženega učenja,

d. evalvacija rezultatov učenja (Knowles, 1975: 26).

Pomembna značilnost priprave učne pogodbe je v tem, da je v celotnem procesu udeleženec aktivno vključen. Ta vključenost je bolj samoumevna v neformalnem izobraževanju, možna pa je tudi v formalnem - kljub vnaprejšnji določenosti izobraževalnih ciljev. 
To pomeni, da so sama vsebina in cilji največkrat nespremenljivi, prilagoditve pa se lahko zgodijo pri tem kako bo posameznik te cilje dosegel.

Podobno razmišlja tudi T. Možina (2004) v zvezi z odločitvijo glede uporabe OIN. Po njenem mnenju bi se morali pred odločitvijo za ustrezno obliko OIN vprašati, kakšne so vrsta izobraževanja (ali je bolj ali manj strukturirano, daljše ali krajše itd.) in značilnosti udeležencev izobraževanja (Možina, 2004: 56).

O’Donnell in Cafferella (199I) naštejeta štiri glavne prednosti učenja s pomočjo učnih pogodb:

a. Fleksibilnost pristopa omogoča mnogotere učne izkušnje

b. Učeči se nadzira proces učenja

c. Učenje s pogodbo omogoča posameznikov razvoj spretnosti načrtovanja lastnega učenja

d. Udeležencem je tako učenje bolj všeč (O’Donnell in Cafferella, I991: 139)

Anderson, Boud in Sampson (1996) pa med prednosti oz. razloge, zakaj je uporaba učnih pogodb smiselna, uvrščajo relavantnost učenja (tako učenje je bolj prilagojeno potrebam učečega se in njegovim ciljem), avtonomnost (učne pogodbe pred učečega postavljajo odgovornost za doseganje postavljenih ciljev in dogovorjenega učenja), strukturo (učna pogodba predstavlja formalni okvir učenja, ki mu daje jasne cilje in usmeritve) in enakost (prilagajanje poteka učenja specifičnim potrebam/značilnostim učečega povečuje zavedanja individualnih ali kulturnih razlik med udeleženci izobraževanja in daje orodje institucijam, da te razlike prepoznajo).

\section{Zakonske podlage za Osebni izobraževalni načrt}

Strokovna in zakonska podlaga za OIN so Navodila o prilagajanju izrednega poklicnega in strokovnega izobraževanja, ki opredeljujejo vsebino in način priprave OIN-a, izdana pa so bila na podlagi 64. člena Zakona o poklicnem in strokovnem izobraževanju (Uradni list RS, št.79/06). OIN je v osnovi namenjen načrtovanju posameznikove izobraževalni poti. OIN naj se pripravi na pobudo posameznika ob pomoči svetovalca oz. organizatorja izobraževanja odraslih. Začne se z uvodnim razgovorom, kjer se na podlagi posameznikovega predhodno pridobljenega znanja pripravi ustrezno dokumentacijo ter vsebinski in izvedbeni načrt nadaljnjega izobraževanja. Izvajalec izobraževanja udeležencu predstavi namen in vsebino izobraževanja, posameznik pa ima možnost OIN dopolniti z lastnimi predlogi. Skupaj torej pripravita načrt izobraževanja (cilje, vsebine, časovni načrt idr.), kjer se upoštevajo želje, potrebe, sposobnosti in zmožnosti posameznika. Iz- 
vajalec izobraževanja in udeleženec se zavežeta in podpišeta pogodbo (Uradni list RS, št. 79/06, I3. Člen).

$\mathrm{V}$ navodilih o prilagajanju izrednega poklicnega in strokovnega izobraževanja, ki opredeljujejo vsebino in način priprave OIN-a (Uradni list RS, št. 79/o6, I 4. člen), je določeno, da naj se za preverjanje uresničevanja OIN uporablja evalvacijski pogovor med udeležencem in izvajalci izobraževanja, in sicer vsaj enkrat letno. Po potrebi se OIN lahko spremeni.

Za OIN je določena vsebina za skupinski (Uradni list RS, št. 79/06, I2.-I 4. člen) in individualni organizacijski model (Uradni list RS, št. 79/06, I5.-18. člen), ki narekuje, katere podatke (I6. člen) in katere postopke za prilagoditev (Uradni list RS, št. 79/06, I5. člen) naj OIN vsebuje. Prepoznavnost pomena OIN je razvidna tudi iz Navodil o prilagajanju izrednega poklicnega in strokovnega izobraževanja (Uradni list RS, št. 8/2008). V I3. členu teh navodil je zapisano, da je OIN dokument, v katerem izobraževalna organizacija poleg »prilagoditev iz izvedbenega načrta za učno skupino opredeli še morebitne posebnosti pri načrtovanju izobraževalne poti za posameznika, ki se razlikujejo od sprejetega izvedbenega načrta za učno skupino«. Te prilagoditve zajemajo določitev vsebin, časovni potek izobraževanja, priznavanje predhodno pridobljenega znanja in načine preverjanja znanja. Osebni izobraževalni načrt stopi v veljavo, ko ga podpišeta udeleženec in izvajalec izobraževanja.

\section{Raziskovalni cilji}

Cilj raziskave je ugotoviti, kakšna je vloga priprave osebnih izobraževalnih načrtov pri spodbujanju motivacije odraslih za izobraževanje, in sicer z vidika večje vztrajnosti, poglabljanja znanja in postavljanja višjih taksonomskih ciljev znanja. To lahko pomembno prispeva $k$ večji motiviranosti odraslih udeležencev za učenje, zmanjševanju osipa v izobraževanju odraslih, uspešnejšemu in kakovostnejšemu pridobivanju znanja in spretnosti, boljšemu izhodišču za razvoj poklicne kariere - učinkovitejši izrabi znanj in spretnosti na posameznem poklicnem področju, za katerega se oseba izobražuje, in spodbujanju vseživljenjskega učenja tudi po zaključku formalnega izobraževanja za pridobitev poklica (Houle, 1961; Tough, 1979; Boeren, Nicaise in Baert, 2010).

\section{Opis raziskave}

Podatki so bili zbrani v okviru evalvacijske raziskave, katere namen je bil ugotoviti, v kolikšni meri se pri izvajanju strokovnega in poklicnega izobraževanja odraslih upoštevajo navodila o prilagajanju izrednega poklicnega in strokovnega izobraževanja, opredelje- 
na v Zakonu o poklicnem in strokovnem izobraževanju (Uradni list RS, št. 79/o6), ter kakšna je vloga osebnega izobraževalnega načrta pri motiviranju odraslih za izobraževanje in zagotavljanju njihovega uspešnejšega dokončanja študija. Pri tem smo proučevali tako mnenja organizatorjev/vodij izobraževanja na različnih ustanovah za izobraževanje odraslih kot tudi mnenja udeležencev izobraževanja. Pri raziskovanju smo iskali odgovore na sledeča raziskovalna vprašanja:

I. V kolikšni meri izvajalci/organizatorji izobraževanja odraslih upoštevajo navodila o prilagajanju izrednega poklicnega in strokovnega izobraževanja, ki opredeljujejo vsebino in način priprave osebnega izobraževalnega načrta?

2. Ali in kako se program izobraževanja prilagaja posamezniku glede na njegov osebni izobraževalni načrt?

3. V kolikšni meri se spremlja uresničevanje sprejetega osebnega izobraževalnega načrta?

4. Koliko so učitelji informirani o osebnih izobraževalnih načrtih udeležencev in v kakšni meri sodelujejo pri uresničevanju osebnih izobraževalnih načrtov?

5. Ali organizatorji izobraževanja in udeleženci izrednega izobraževanja osebni izobraževalni načrt vidijo kot motivacijsko sredstvo? V kakšnem smislu?

6. Do kakšnih težav prihaja pri uresničevanju osebnega izobraževalnega načrta? $S$ katerimi ovirami se soočajo organizatorji in s katerimi udeleženci izobraževanja?

7. Koliko strokovna usposobljenost za pripravo in izvedbo osebnega izobraževalnega načrta vpliva na doseganje ciljev udeleženca kot izvajalca?

8. Kakšne spremembe bi bile potrebne, da bi OIN lahko postal ustrezno motivacijsko sredstvo za udeležence?

Raziskava je potekala kot kombinacija kvantitativnega in kvalitativnega pristopa. S kvantitativnim raziskovanjem smo želeli ugotoviti mnenja strokovnjakov na izobraževalnih ustanovah o osebnem izobraževalnem načrtu in težave, $s$ katerimi se srečujejo pri njegovem uresničevanju. V vzorec evalvacijske raziskave smo vključili vodje oz. organizatorje izobraževanja na izbranih ljudskih visokih šolah in oddelkih za odrasle na srednjih poklicnih in strokovnih šolah in s spletno anketo ugotavljali stališča organizatorjev in vodij izobraževanja odraslih do omenjenih vprašanj. Vprašanja v anketnem vprašalniku so razdeljena $\mathrm{v}$ pet sklopov in sicer:

- Podatki o instituciji, respondentu

- Priprava in izvajanje osebnega izobraževalnega načrta 
- Uporabnost osebnega izobraževalnega načrta

- Učinki osebnega izobraževalnega načrta na motivacijo odraslih udeležencev izobraževanja

- Druga mnenja in predlogi

Anketni vprašalnik je bil poslan na 22 izobraževalnih ustanov (9 ljudskih univerz in I3 enot za izobraževanje odraslih na srednji šoli) po vnaprejšnjem dogovoru. Anketiranje je potekalo maja in junija $201 \mathrm{I}$. Vrnjenih je bilo 17 vprašalnikov, 9 iz ljudskih univerz in 7 iz enot za izobraževanje odraslih na srednjih šolah (ena institucija ni odgovorila na vprašanje o vrsti institucije in je ostala neopredeljena). Podatke smo statistično obdelali in za prikaz podatkov uporabili frekvenčne tabele (Priloga 2). Podatke, pridobljene z odprtimi vprašanji, smo kodirali in jih na podlagi krovnih pojmov tudi interpretirali.

Vlogo osebnega izobraževalnega načrta in motivacijski pomen oblikovanja osebnega izobraževalnega načrta smo želeli raziskati tudi z vidika udeležencev in $v$ ta namen izvedli kvalitativno raziskavo. Oblikovali smo polstrukturirani intervju, s katerim smo na vsaki od izbranih institucij intervjuvali po 2-3 udeležence strokovnega ali poklicnega izobraževanja odraslih. Vprašanja za poglobljene intervjuje z odraslimi udeleženci smo oblikovali s ciljem, da ugotovimo njihove motive in ovire pri izobraževanju, priznavanje prejšnjih znanj in izkušenj, seznanjenost in sodelovanje pri oblikovanju osebnega izobraževalnega načrta, vrednotenje, spremljanje in uresničevanje osebnega izobraževalnega načrta, vrednotenje dela učiteljev itd. Tako smo v intervju vključili vprašanja, kot so: kakšna je vloga odraslih udeležencev izrednega poklicnega in strokovnega izobraževanja pri pripravi osebnega izobraževalnega načrta, kako poteka načrtovanje osebnega izobraževalnega načrta, $s$ katerimi težavami se srečujejo pri izobraževanju in kakšna je vloga osebnega izobraževalnega načrta pri njihovem zmanjševanju, kako se način dela prilagaja načrtom, zapisanim v osebnem izobraževalnem načrtu itd.

Za namene kvalitativnega raziskovanja smo izvedli 62 intervjujev z odraslimi udeleženci programov strokovnega ali poklicnega izobraževanja na ljudskih univerzah in srednjih šolah. Med intervjuvanci je bilo 30 moških in 32 žensk, od tega jih je 49 (80 \%) sodelovalo v organiziranem izobraževanju, I 4 (20\%) pa v individualiziranem organizacijskem modelu (samostojno, opravljajo le izpite). Izvedba poglobljenih intervjujev je potekala $\mathrm{v}$ aprilu in maju 20I2. Intervjuvanje so izvajali študenti 4. letnika andragogike, ki smo jih za to posebej usposobili. Zanimalo nas je sovplivanje dejavnikov, $s$ katerimi bi osvetlili razumevanje pomena OIN in njegove motivacijske funkcije s strani udeležencev izobraževanja. Pri tem smo se zavedali specifičnosti tovrstnega kvalitativnega raziskovanja, ki 
omogoča sklepanje na podlagi analize primerov, podprte z ustreznimi teoretskimi predpostavkami. To raziskovanje omogoča postavitev »sorazmerno verjetne teorije « (Mesec, I998: 48), nikakor pa ne sklepov, ki bi temeljili na preverljivih dejstvih in zakonitostih. Poskušali smo z analitično indukcijo sklepati, kakšna je po njihovem mnenju vloga OIN v spletu celotnih ukrepov za motiviranje in pomoč pri učenju. Naše raziskovanje je sledilo izhodiščem, ki sta jih zagovarjala Strauss in Corbin (1990), prej pa tudi Glaser in Strauss (1967) v svojem pojasnjevanju utemeljene teorije ${ }^{2}$ (angl. Grounded Theory). Gre za induktivno sklepanje iz niza podatkov, ki pa ne omogoča dedukcije. Kot pomemben del raziskave smo upoštevali tudi sam proces raziskovanja in analitično opazovali vse spremembe dejavnosti, ki so se pojavljale v času.

\section{Rezultati in razprava}

Vse institucije, ki so odgovarjale na vprašalnik, izvajajo programe srednjega strokovnega izobraževanja odraslih, 8I \% pa jih izvaja tudi programe srednjega poklicnega izobraževanja odraslih. Ugotovitve kažejo, da poteka v anketiranih organizacijah za izobraževanje odraslih več kot polovica ( $55 \%$ ) vsega srednjega poklicnega in strokovnega izobraževanja odraslih v obliki individualiziranega organizacijskega modela (udeleženci se v okviru tega modela samostojno izobražujejo, imajo pa možnost konzultacij in individualne pomoči pred izpiti), 44 \% izbranih organizacij pa izobraževanje za odrasle izvaja organizirano (predavanja, konzultacije in izpit).

\section{Načrtovanje osebnih izobraževalnih načrtov}

Upostevanje določbe zakona o strokovnem in poklicnem izobraževanju

$\mathrm{V}$ anketi nas je zlasti zanimalo, v kolikšni meri izbrane organizacije upoštevajo določbe zakona o strokovnem in poklicnem izobraževanju glede priprave in implementacije osebnega izobraževalnega načrta (OIN) v programih za odrasle.

Vse anketirane organizacije za izobraževanje odraslih odgovarjajo, da so seznanjene z določbami Zakona o strokovnem in poklicnem izobraževanju, ki opredeljuje vsebino izdelave OIN. Na vprašanje, ali pri svojem delu upoštevajo določila tega zakona, je $87,5 \%$ vprašanih organizatorjev izobraževanja odraslih odgovorilo, da določila upoštevajo, I2,5 \% jih določila upošteva delno, takih, ki določil ne bi upoštevali, pa ni. Tisti, ki določila upoštevajo delno, kot razloge navajajo zlasti pomanjkanje kadra. Pomanjkanje kadra organizatorji izobraževanja odraslih tudi sicer pogosto navajajo kot razlog težav pri izvedbi iz-

2 Izbrali smo prevod »utemeljena teorija «, ki ga uporablja Blaž Mesec; drugi avtorji so termin Grounded Theory prevajali še kot »pritlehna teorija $\ll$ (V. Flaker), »bazična teorija $\ll(B$. Dekleva $)$ ipd. 
obraževanja odraslih nasploh, še zlasti pa pri pripravi OIN, ki zahteva veliko časa in individualno delo z odraslimi.

Vse anketirane organizacije za izobraževanje odraslih so na vprašanje, ali pripravljajo OIN za udeležence izrednega izobraževanja, odgovorile pozitivno. Odgovori intervjuvanih udeležencev na enako vprašanje se razlikujejo; od 62 udeležencev je 42 potrdilo, da imajo svoj OIN, I 8 jih je odgovorilo, da ga nimajo, 2 pa sta izjavila, da imajo na njihovi izobraževalni instituciji vsi skupinski OIN, ki je zelo splošen, brez ciljev in prilagoditev posameznikom. Kot kažejo odgovori udeležencev, na šestih izobraževalnih organizacijah, ki so bile vključene v raziskavo, ne pripravljajo OIN za odrasle udeležence, kar pa ni zanesljiv podatek, saj so tudi znotraj posameznih institucij odgovori udeležencev različni - eni trdijo, da imajo OIN, drugi, ki se izobražujejo v isti instituciji pa izjavljajo, da za OIN prvič slišijo.

Zanimalo nas je, kako organizacije pripravljajo OIN. Zakon določa OIN kot pisni dokument, ki vsebuje najmanj podatke o formalnih in neformalnih delovnih izkušnjah, zaključenem predhodnem formalnem izobraževanju, podatke o znanju, pridobljenem z neformalnim izobraževanjem, podatke o predvidenem načinu in poteku izobraževanja in načine ter časovne roke za spremljanje uresničevanja osebnega izobraževalnega načrta. Vse to se običajno pripravi v času uvodnega razgovora, kjer se natančneje opredelijo posameznikove želje in pričakovanja ter se presodi, katera znanja, ki jih je udeleženec pridobil v preteklosti, bi lahko priznali oz. upoštevali.

Navedbe organizatorjev/vodij izobraževanja odraslih v izbranih organizacijah kažejo, da v OIN najpogosteje opredelijo dosežke posameznika, ki izhajajo iz predhodnega formalnega izobraževanja. Znanje in izobrazba, ki ju posameznik že ima, sta namreč ključna pri načrtovanju nadaljnjega izobraževanja, kar je del OIN. Večina organizatorjev/vodij izobraževanja odraslih v OIN vključi podatke o formalnih in neformalnih delovnih in drugih izkušnjah (kvalifikacijah) kandidata (88 \% jih to naredi vedno ali pogosto), podatke o zaključenem predhodnem formalnem izobraževanju, vključno z morebitnimi posebnostmi ( $94 \%$ pogosto ali vedno), podatke o predvidenem vsebinskem in časovnem poteku izobraževanja (več kot $90 \%$ anketirancev to naredi pogosto ali vedno), podatke o načinih in rokih preverjanja znanja (skoraj $90 \%$ ), nekoliko manj pogosto pa tudi podatke o znanju, pridobljenem v neformalnem izobraževanju, podatke o poteku in časovnih rokih za spremljanje uresničevanja osebnega izobraževalnega načrta ter predloge za potek konzultacij in opredelitev, kako se bo udeležencu pomagalo pri dostopu do ustreznih učnih virov. Le približno četrtina anketiranih organizatorjev/vodij izobraževanja odraslih nava- 
ja, da v OIN opredelijo tudi želje in interese udeležencev izobraževanja, približno petina, da se pogovarjajo tudi o neformalno pridobljenem znanju udeležencev, le približno desetina pa udeleženca seznani tudi z možnostjo, da mu lahko neformalno pridobljeno znanje priznajo.

\section{Uvodni razgovor z udeleženci izobraževanja odraslih}

Prvi korak, da se pripravi OIN, je uvodni razgovor. V večini (94 \%) anketiranih organizacij navajajo, da z udeleženci opravijo tak uvodni razgovor; na vprašanje, kako poteka uvodni razgovor in o čem se dogovorijo, pa organizatorji/vodje izobraževanja odraslih navajajo med drugim tele odgovore:

»Na podlagi vnaprej pripravljenih vprašanj se ob vpisu pogovorimo z udeležencem.«

»Preverimo dokumentacijo - spričevala, potrdila. ¿̌e je mogoče, testiramo, kateri izpiti bodo priznani. Glede na to izpolnimo OIN, v katerem predvidimo, koliko let bo trajalo izobraževanje, obveznosti za eno šolsko leto, plačila šolnine. Nato podamo informacije glede urnika, predavanj, dodatne informacije ...«

$\gg V$ prvi fazi kandidata vprašamo, za kateri program se zanima. Zakaj se je za ta program odločil? Vprašamo ga po njegovih pričakovanjih, izkušnjah ...V drugi fazi pogovora kandidata seznanimo s potekom izobraževanja, z možnostmi priznavanja formalnega in neformalnega izobraževanja, s solskimi pravili, predstavimo mu našo organizacijo in naše delo in še druge podrobnosti.«

»Udeleženec se predstavi - pove, od kod prihaja, zakaj se je odločil za našo šolo, na kakšen način se želi izobraževati (predavanja ali konzultacije), koliko časa namerava študirati (hitro ali počasi). Pove tudi svojo predhodno izobrazbo. Pove tudi svoje posebnosti (zaposlen, mati, ...). Nato skupaj narediva osebni izobraževalni načrt.« »Kandidate seznanimo z izobraževalnim programom, obliko in načini izvajanja izobraževalnega procesa, preverjanja znanja, merili in postopki za priznavanje, šolskim redom, mapo učnih dosežkov, osebnim izobraževalnim načrtom, pogodbo, ceno, načinom plačevanja, kako jim lahko med izobraževanjem pomagamo ( $k a-$ kšne so vrste in načini podpore), e-učilnico in drugimi posebnostmi izobraževanja na naši $L U . \ll$

Vidimo, da organizatorji/vodje izobraževanja odraslih uvodne razgovore opravljajo na različne načine in pri tem sledijo različnim ciljem; ponekod so uvodni pogovori bolj osebni, drugod pa bolj informativne narave. 
O poteku uvodnega razgovora smo spraševali tudi odrasle udeležence srednjega strokovnega in poklicnega izobraževanja. Skoraj vsi odrasli udeleženci so, podobno kot organizatorji/vodje izobraževanja odraslih na izbranih institucijah, navedli, da so bili ob začetku izobraževanja povabljeni na uvodni razgovor, kjer so se - večinoma z organizatorjem izobraževanja - pogovarjali glede vpisnih zahtev, poteka izobraževanja in individualnih možnosti. Po njihovih besedah je bil uvodni razgovor večinoma namenjen seznanjanju s potekom izobraževanja in finančnimi zadevami ter pripravi učnega načrta. Odrasli udeleženci izobraževanja takole opisujejo potek uvodnega pogovora:

$\gg \mathrm{V}$ bistvu sva z vodjo izobraževanja nardila učni načrt, kako bo kaj potekal. Sva use skupaj splanirala ...«

»Pogovorile smo se o tem, katere predmete bom naredila in kako bo potekal celoten postopek priznavanja predmetov, prekvalifikacije ...«

>Prvi dan, ko sem prišla se pozanimat, so mi vse od A do Ž lepu razložil, vsa vprašanja ki sem jih mela so mi razvuzlal. Šla sem v svetovalno središče, sm uprašala po razpisih, kaj majo, kaj nudjo. Pa so mi še povedal za financiranje. Največji izziv je bil , da dobim povrnjene stroške. Katere predmete bom imela, kuk je za plačat, na kuk obrokov, kero smer si labko izberem. Vse. Uvodni razgovor je bil tak, da nas je moralno malo - sej boš, sej ni težko, dobila sem to mapo (OIN). Tudi pogodbo smo skupaj nrdile. Tud zdej, kadarkoli mam kakšno vprašanje, se obrnem na njo.« »...tko ... bolj sproščeno, vprašala me je, kako si js to predstavljam, na kratko sem ji pač povedala, da mam to željo, da bi to zaključla, da ne bi rada pač to dolgovezla ... sm vztrajala pri svojem in pol smo tudi realizirali ne in je tudi odobrila, tko da ... Vidla je ta zagon in ... (majhna tišina) je vidla no, da bo tako, da bo šlo ne.«

Redki odrasli udeleženci izobraževanja so se na uvodnem razgovoru z organizatorji izobraževanja odraslih pogovarjali tudi o preteklem izobraževanju in znanjih, ki so si jih pridobili. Taka je izjava ene od intervjuvank:

»Ja ... o šoli. Kje sem končala OŠ, sem hodila še na kakšna predavanja potem, Kakšne tečaje ... «

Glede poteka uvodnega razgovora večina odraslih udeležencev izobraževanja navaja, da je ta potekal individualno; le nekateri intervjuvanci navajajo, da so uvodni pogovori potekali v skupini: 
»Bili smo vsi udeleženci in vodja izobraževanja. Obrazložil nam je, koliko časa traja izobraževanje, znesek plačila, tema je bila samo okrog tega.«

Tisti udeleženci izobraževanja, ki pravijo, da uvodnega razgovora ob vpisu niso imeli, pa to obrazložijo takole:

» Nč, v bistvu informativni dnevi, $\mathrm{k}$ so bili.«

\section{Priznavanje predhodno pridobljenih znanj}

Odrasli udeleženci strokovnega in poklicnega izobraževanja odraslih vsebino uvodnih razgovorov povezujejo zlasti $z$ načrtovanjem lastnega izobraževanja; pri tem poudarjajo, da je bila pripravljenost šole za priznavanje njihovega predhodno pridobljenega znanja velika. Intervjuvanci navajajo, da so jim na instituciji predhodno pridobljena znanja priznali, če je to le bilo mogoče. To potrjujejo tudi nekatere izjave intervjuvancev:

»Ja, neki so mi priznal, k sm že enkrat prej hodu, sam nism dokončau pruga letnika do konca.«

»Ja ja, imela sem kr neki, ampak glede na to, da je to višja stopnja izobrazbe, kot je sam natakar oz. trgovec ... aaa ... zelo malo. Tudi slovenšcina za drugi letnik mi je bla priznana na primer, ker je nižja stopnja. Tako da sem morala veliko izpitov opravit, mislim, da jih je blo okrog 47 vseh skupaj.«

Kar nekaj odraslih udeležencev izobraževanja po drugi strani navaja, da so jim že opravljene predmete ali del vsebin želeli priznati, vendar se sami niso odločili za to. To pojasnjujejo takole:

»Lahko bi mi priznal. Sm naredu dve let turistične šole, sam sm se odloču, da bom delu vse od začetka. Nima v bistvu povezave z računalništvom, zato sem se odloču, da grem od začetka.«

»... Ne, in tudi če bi mi priznali, jaz bi morala vse to znati ... veste, je čisto drugače, js ka sem hodila so bili cisto drugačni programi kot zdaj. Je res velika razlika ... in tudi ne vem, č bi kaj odnesla, ker $v$ naslednjih letnikih bi to znanje rabla, ker znanje se nadgrajuje... zaj pa, če ne bi imela osnov, ne vem, kako bi slo ... ker jaz imam tudi otroka $v$ OŠ in se je ful spremenilo.«

Oblikovanje in izvedba osebnih izobraževalnih načrtov Priprava osebnega izobraževalnega načrta vizobraževalnih programih srednjega poklicnega in strokovnega izobraževanja za odrasle 
Organizatorji/vodje izobraževanja odraslih navajajo, da pri sestavi OIN največkrat sodeluje organizator izobraževanja (tako je odgovorilo $94 \%$ vprašanih), nekateri pa k pripravi vključijo tudi svetovalca ( $25 \%$ ). Sicer pa je večina anketirancev poudarila, da je vloga organizatorja izobraževanja odraslih pri pripravi OIN ključna oz. zelo pomembna, saj opravi uvodni razgovor ter nudi svetovanje in pomoč.

$\mathrm{V}$ raziskavi nas je zanimalo, kako se na izobraževalnih institucijah lotijo priprave OIN-a. Večina organizatorjev/vodij izobraževanja odraslih (88 \%) navaja, da OIN pripravijo za vsakega odraslega udeleženca izobraževanja posebej, kar v i3. členu tudi določa Zakon o poklicnem in strokovnem izobraževanju. Dve tretjini anketirancev navajata, da pripravijo OIN individualno, z vsakim posameznikom posebej, tretjina pa jih OIN pripravi kombinirano, torej delno individualno, delno pa skupinsko.

$\gg$ Razgovori potekajo individualno; $v$ času vpisa, septembra, ko je gneča, organiziramo $2-x$ na dan skupinske razgovore.«

Vse vključene institucije pripravljajo OIN za celotno šolsko leto in ne za vsak predmet posebej.

V Zakonu o poklicnem in strokovnem izobraževanju je v iz. členu zapisano, da predlog osebnega izobraževalnega načrta »izvajalec izrednega izobraževanja predstavi in obrazloži udeležencu, ki lahko predlaga spremembe ali dopolnitve osebnega izobraževalnega načrta. Osebni izobraževalni načrt je določen, ko ga podpišeta udeleženec in izvajalec izobraževanja.« Zato nas je zanimalo, ali priprava OIN v izbranih izobraževalnih organizacijah poteka v skladu s temi določili; kakšna je pri pripravi OIN vloga udeleženca izobraževanja oz. ali se pri pripravi načrta v kar največji meri upoštevajo tudi potrebe in želje udeležencev ter značilnosti njihovega dozdajšnjega izobraževanja. Večji del organizatorjev/vodij izobraževanja odraslih je odgovoril, da OIN pripravljajo skupaj z udeležencem:

$\gg$ Kandidat pove podatke $\mathbf{v}$ uvodnem razgovoru, pred in med pripravo načrta /OIN, op. avtorji/ pa še druge pomembne podatke za potek in planiran zaključek izobraževanja: ali bo labko obiskoval vsa predavanja, kdaj želi opravljati maturo oz. zakljucni izpit, katere programske enote se mu priznajo iz drugih izobraževanj ...«; >Podlaga za pripravo OIN je odločba o priznavanju predhodno pridobljenega znanja v programu, $v$ katerega je posameznik vpisan, in organizacijskih načrtov šole (konzultacije, organizirano izobraževalno delo, izpitni roki ...). Načrt pripravimo skupaj z udeležencem, pri čemer upoštevamo njegove izkušnje, možnosti in zmožnosti.« 
»Poskušamo ga pripraviti skupaj z udeležencem, saj ga le-ta mora podpisati.«

Nekateri organizatorji/vodje izobraževanja odraslih navajajo, da predloge pripravijo predhodno, nato pa jih ob sodelovanju udeleženca po potrebi popravijo in dopolnijo. Nekateri navajajo, da se trudijo čim bolj upoštevati odraslega udeleženca izobraževanja, kajti udeleženec na koncu dogovor tudi podpiše in s tem potrdi, da se z njim strinja. Anketirani organizatorji izobraževanja odraslih to pojasnijo takole:

>Predlogo pripravi organizator. $Z$ vsakim udeležencem glede na pripravljen OIN predebatiramo in vnesemo popravke in želje udeležencev.«

»Večino načrta pripravljam sam. Udeleženec sodeluje s predložitvijo dokumentacije za formalno in neformalno priznavanje vsebin (čeprav neformalno pridobljenega znanja zaradi nedorečenosti v zvezi z ocenjevanjem praktično ne moremo priznati, če ni ocene), s svojo vizijo izobraževanja, s podatki in mnenji, koliko je lahko obremenjen itd.«

Po navedbah organizatorjev/vodij izobraževanja odraslih OIN občasno pripravljajo tudi kombinirano, torej skupinsko in individualno, pač glede na potrebe udeležencev. Le eden od anketiranih organizatorjev/vodij izobraževanja odraslih je eksplicitno navedel, da udeleženca izobraževanja pozovejo, da pove kaj več o sebi, svojem socialnem okolju, o možnostih za učenje in izobraževanje, o svoji finančni situaciji in pričakovanjih, o ovirah, ki jih doživlja. Prav ta vprašanja pa so pomembna, če naj bi OIN predstavljal orodje za pomoč udeležencu izobraževanja. Ugotovimo lahko, da OIN tako izgublja nekatere od pomembnih motivacijskih funkcij, ki bi se s tem vzpostavile.

Tudi odrasle udeležence poklicnega in strokovnega izobraževanja smo vprašali, koliko in kako so sodelovali pri pripravi OIN in kakšna je bila konkretno njihova vloga v tem procesu. Zanimalo nas je, kako so doživljali proces priprave OIN - torej ali kot nekaj za njih koristnega in uporabnega ali bolj kot obveznost, ki jo vsiljuje izobraževalna institucija.

Približno tretjina odraslih udeležencev (20) navaja, da so dejavno sodelovali pri pripravi OIN, kar pomeni, da so imeli vpliv na cilje, zastavljene v OIN, in da so se pri pripravi OIN upoštevale njihove želje in pričakovanja. Prav toliko (2I) intervjuvancev navaja, da OIN sicer imajo, vendar pa so ga organizatorji pripravili že vnaprej, brez njihovega sodelovanja, nadaljnja tretjina intervjuvancev pa pravi, da OIN nimajo oz. ga ne poznajo. Iz tega lahko sklepamo, da mnogi odrasli udeleženci izobraževanja (skoraj dve tretjini) pri pripravi OIN niso dejavno sodelovali, zato OIN tudi niso razumeli kot možnost za 
uspešnejše načrtovanje učnega procesa, motivacijski dejavnik in orodje za vrednotenje lastnega napredka pri učenju. Sicer pa je, kot smo že navedli, tudi v Zakonu o poklicnem in strokovnem izobraževanju zapisano, da izvajalec izobraževanja OIN lahko sam pripravi v naprej in ga udeležencu le predstavi, kasneje pa ga skupaj dopolnita ali spremenita, če je to potrebno (predno ga udeleženec tudi podpiše). Zaradi mnogih dejavnikov (ki jih bomo predstavili v nadaljevanju), pa do sprememb in dopolnitev vnaprej pripravljenih OIN pogosto ne pride.

Poglejmo, kako odrasli udeleženci pojasnjujejo svoje sodelovanje pri pripravi OIN. Odrasli udeleženci izobraževanja, ki so dejavno sodelovali pri pripravi OIN, so OIN razumeli kot priložnost za uveljavitev lastnih potreb in uresničitev želja ter kot pomemben mehanizem za samopomoč. Ena od intervjuvank, ki je dejavno sodelovala pri pripravi OIN, to pojasnjuje takole:

$\gg \mathrm{V}$ bistvu to je blo tako nekako sproščeno. ... v referatu mi je rekla, da se dogovorims $X X X X$ za termin, da pridem do nje, da se malo pogovorimo, kaj in kako, in da sestavimo magari ta OIN. Ni se mi zdelo to ena stvar, ki je potrebna vsakemu učencu. Kasneje sem nekako dognala, da čisto vsi so delali ta OIN. Tako da nekako js sm zagrabla to priložnost, se mi je zdela prou priložnost.

Šla sem do XXXX, dogovorili sva se za termin, malo smo se pogovarjale, kakšne so moje želje, kakšni so moji cilji, prepustila mi je pač besedo, tako da je tudi sama vidla, kaj si js želim ... nekako moja pričakovanja ...«

Nekateri odrasli udeleženci izobraževanja, ki so OIN dobili pripravljen v naprej, menijo, da so organizatorji izobraževanja skušali upoštevati njihove potrebe, a so (verjetno po uvodnem razgovoru) OIN pripravili sami in ga udeležencu ponudili v podpis.

$\gg \mathrm{Ne}$, so mi ga pripravili oni in mi ga samo predali. Sem se strinjal. Dobil sem urnik, na katerem je bilo prav za mene označeno, kam moram še hoditi in kaj imam že opravljeno oz. priznano. Dobilsem tudi seznam predmetov in označeno, kaj imam priznano in skakšno oceno. Tudi potrdilo, da se mi upošteva praktični pouk, glede na to, da toliko let opravljam delo.«

Drugi udeleženci izobraževanja odraslih navajajo, da OIN ni bil pripravljen individualno, temveč so jim ga organizatorji izobraževanja zgolj predstavili, večinoma v skupini. To seveda pomeni, da individualne potrebe v tem načrtu niso upoštevane, da se izobraževanje $\mathrm{v}$ tem primeru ne prilagaja potrebam, zapisanim v OIN, ter da gre v glavnem za na- 
črt opravljanja izpitov, izpitnih rokov in drugih dejstev, ki jih udeleženec ob vpisu v nek izobraževalni program prejme. To ponazarja izjava ene od intervjuvank:

»To je že blo pripravleno, ne, jaz mislim, da smo to dobili nekako vsi enako.«

Odrasli udeleženci izobraževanja, ki trdijo, da OIN nimajo oz. da ga ne poznajo, pa na vprašanje, ali so na instituciji pripravili OIN in ali vedo, čemu je namenjen, odgovarjajo:

$\gg$ Ne niso. Kakšnikrat je bolš nič ne vedet.«

»Sploh pojma nimam. Prvič slišim za to.«

Če se pri pripravi OIN posameznikovih potreb in posebnosti ne upošteva, tak dokument ne opravlja motivacijske funkcije, ki naj bi jo imel. Na podlagi opravljenih intervjujev lahko ugotovimo, da velik delež ( $v$ našem primeru skoraj dve tretjini intervjuvanih) odraslih udeležencev poklicnega ali strokovnega izobraževanja odraslih OIN bodisi nima pripravljenega tako, kot zahtevajo Navodila o prilagajanju izrednega poklicnega in strokovnega izobraževanja, bodisi niso bili posebej opozorjeni, da pripravljajo OIN, sami pa temu tudi niso posvečali prave pozornosti. Vsekakor naj bi bil OIN pripravljen s sodelovanjem udeleženca in zanj, za njegove potrebe in za uspešno napredovanje v procesu izobraževanja.

Vpliv udeležencev poklicnega in strokovnega izobraževanja odraslih na vsebino osebnega izobraževalnega načrta

Odraslim udeležencem izobraževanja smo postavili vprašanja o tem, na kakšen način so prispevali k vsebinski zasnovi svojega OIN. Zanimalo nas je, koliko so vplivali na vsebino OIN in na kakšen način. Glede vsebine OIN tisti intervjuvanci, ki svoj OIN poznajo in so pri njegovi sestavi sodelovali, pravijo, da gre večinoma za opis že dosežene izobrazbe in znanj, opredelitev predmetov in predmetnika, datume opravljanja izpitov ter ključne cilje izobraževanja. To dokazujejo izjave:

»Nekaj ja, poznam. Piše notri, katera dela si opravljal. Ja ja, to piše notr.« $\gg$ Ja od prejšne šle mam napisan not, kva sm naredu, tist so mi priznal. Tm sm dva letnika dokončov, kle mam pa še za tret letnk use za narest.«

Velik delež odraslih udeležencev, ki OIN imajo, hkrati tudi meni, da v OIN niso vključene prilagoditve, ki upoštevajo njihove potrebe in želje. To orišejo navedbe:

»V njem ni ciljev mojga izobraževanja, so pa načini, kako bom prišla do zaključka. Kajmi bo priznano.« 
$\gg$ Ne da bi vedel. Edino to, da se mi prizna praksa.«

»Želje ja, izkušnje pa ne, ker sem iz drugega poklica in ni kejprimerjat.«

Nekateri odrasli udeleženci izobraževanja pa niti ne vedo, kaj je zapisano v njihovem OIN, kar dokazuje, da ga ne uporabljajo za vrednotenje lastnega napredka v izobraževalnem procesu in verjetno tudi ne kot motivacijsko sredstvo. Izjave treh intervjuvank v zvezi s tem so nazorne:

»Ej, se niti ne spomem, kaj točn use že notr piše ... pač ti podatki, pa kere izpite že mam, kere še rabm, kdaj morm kej nardit.«

$\gg$ Ne vem, sam verjetn ja, ne vem, po mojepa že.«

»Pogledala sem si ga /OIN, op. avt./, ampak ne vem točn. Jz sem si vse pomembne stvari dala v svojo mapo al pa jih mela v glavi. Vse cilje sem si zadala $v$ glavi, nism jih pisala. Tud če bi pisala, kaj tu pomaga, tu je samu eno čičkanje.«

Informiranost učiteljev o osebnih izobraževalnih načrtih udeležencev in njihovo sodelovanje pri uresničevanju osebnega izobraževalnega načrta posameznika

Učitelji so lahko pomembni členi pri pripravi OIN, zlasti pa pri izvajanju izobraževanja v skladu z načrtovanimi cilji, zapisanimi v OIN. Na vprašanje, ali menijo, da so učitelji na izobraževalnih ustanovah ustrezno informirani o vlogi in pomenu OIN, je največji delež (44\%) vprašanih organizatorjev/vodij izobraževanja odraslih odgovorilo, da učitelji poznajo vlogo OIN precej slabo ali zelo slabo, drugi anketirani organizatorji/vodje izobraževanja odraslih pa menijo, da so učitelji srednje ali dobro seznanjeni z vlogo in pomenom OIN. Nihče ni odgovoril, da so učitelji z vlogo in pomenom OIN zelo dobro seznanjeni. Podatki namreč tudi kažejo, da pri uvodnem razgovoru z udeleženci izobraževanja odraslih sodelujejo večinoma organizatorji izobraževanja odraslih $(78,9 \%)$, v petini primerov sodelujejo tudi svetovalci, nihče pa ni navedel, da pri razgovoru sodeluje tudi učitelj ali kdo drug. To kaže, da so učitelji v pripravo in spremljanje OIN vključeni bolj izjemoma, iz česar lahko vnovič sklepamo, da se OIN prepogosto razume kot dodatno administrativno zahtevo, s katero imajo veliko dela zlasti organizatorji izobraževanja. V tabeli 28 so predstavljeni odgovori organizatorjev/vodij izobraževanja odraslih na vprašanje, ali so po njihovem mnenju učitelji na izobraževalnih ustanovah informirani o vlogi in pomenu osebnega izobraževalnega načrta. 
Tabela I6: Informiranost učiteljev o vlogi in pomenu osebnega izobraževalnega načrta

\begin{tabular}{|l|c|c|}
\hline Odgovori & Frekvenca & Odstotek \\
\hline I (Zelo slabo) & I & $6,3 \%$ \\
\hline 2 (Precej slabo) & 7 & $43,8 \%$ \\
\hline 3 (Srednje) & 6 & $37,5 \%$ \\
\hline 4 (Kar dobro) & 2 & $12,5 \%$ \\
\hline 5 (Zelo dobro) & 0 & $0,0 \%$ \\
\hline Skupaj & 16 & $100,0 \%$ \\
\hline
\end{tabular}

Odgovori niti niso presenetljivi, če jih presojamo po navedbah anketirancev, da učitelji v nobeni od institucij ne sodelujejo pri pripravi OIN; če pa jih presojamo z vidika smiselnosti priprave OIN, pa so seveda ti podatki neugodni. Učitelji naj bi namreč dejavno sodelovali pri zagotavljanju uspešne izobraževalne poti udeležencev izobraževanja, kar bi zahtevalo dobro poznavanje želja, pričakovanj in pripravljenosti odraslih za obvladovanje izzivov v izobraževalnem procesu. Če so učitelji v celoti izločeni iz tega procesa, se lahko pojavijo le v vlogi posredovalca znanj in v končni fazi tudi tistega, ki znanje vrednoti, manjša pa je verjetnost, da bodo v vlogi spodbujevalca in svetovalca pri učenju. Prav te učiteljeve vloge naj bi bile pri izobraževanju odraslih bolj prisotne, saj zagotavljajo dejavno in bolj problemsko naravnano učenje ter potrebam odraslih bolj prilagojeno poučevanje.

$\mathrm{Na}$ vprašanje, ali se organizatorji/vodje izobraževanja odraslih z učitelji posvetujejo o ustreznosti OIN za posameznega udeleženca, polovica anketirancev odgovarja pritrdilno, polovica pa negativno. Tisti, ki se z njimi posvetujejo, v približno enakem deležu odgovarjajo, da evalvacijski razgovor z učitelji opravijo enkrat, dvakrat ali večkrat letno. Ti odgovori so v nasprotju s prej zapisanimi navedbami, da učitelji večinoma niso vključeni v pripravo OIN, pa tudi z navedbami, da so s pomenom in vlogo OIN slabo seznanjeni.

Ali se z učitelji posvetujejo v zvezi z OIN, smo spraševali tudi odrasle udeležence poklicnega in strokovnega izobraževanja. Noben od intervjuvancev ne navaja, da bi se z učitelji kakorkoli pogovarjal o OIN; po mnenju mnogih intervjuvancev je večina učiteljev v učnem procesu sicer pripravljena pomagati, če se pojavijo težave, vendar pa ta pomoč ni povezana $z$ doseganjem ciljev in uresničevanjem zahtev, zapisanih v OIN, temveč je vezana na pomoč pri učnih urah in tekom izobraževalnega procesa. Nekaj intervjuvancev to pomoč opisuje takole: 
»Več al mn so pa učitelji kar v redu. Ni problema, so pripravljeni pomagat in razložit «.

$\gg$ Učitelji so vedno dobre volje in ure hitro minejo. Nikoli ni dolgočasno, ni samo piflanje, se tudi nasmejimo ... če rabimo pomoč, jih labko prosimo zanjo, ni jim problem pomagati.«

»Vprašajo nas, če razumemo snov, pa če ne razumemo, ponavljajo isto stvar tako dolgo, da je vsem jasno, trudijo se nas motivirat, pa spodbujajo v smislu <saj bo šlo, saj boste zmogli $>$...

»Ja, upoštevajo naše potrebe, še posebej moje, ker mam težave s sluhom, saj sem naglušna. Že od začetka vedo za moje težave, zato mi, če jih prosim, dajo zapiske.«

Nekateri odrasli udeleženci izobraževanja pa spodbude s strani učiteljev ocenjujejo kot neustrezne oz. nezadostne; nekaj udeležencev je navedlo, da učitelji niso ustrezno usposobljeni za delo z odraslimi, pa tudi, da jih nekateri obravnavajo kot otroke:

$\gg$ Se moramo sami spodbujati, oni nas ne.«

»Če si motiviran sam, bošnaredu, motivacije s strani profesorjev ni. Vsajmen se tko $z d i \ll$.

»Ja, hotel bi več pomoči od učiteljev.«

Zelo spodbudno je, da smo od odraslih udeležencev izobraževanja na vprašanje, ali so učitelji taki, kot so pričakovali, kar pogosto dobili takle odgovor:

$\gg$ Ja, še boljši.«

»Ja, se prilagodijo ... tako da je že kar grozno včasih. Tukaj smo le ... ljudje z različnimi izkušnjami, splošno razgledanostjo, z različnimi izobrazbami, takšnimi al drugaćnimi in ... neko osnovno, enotno znanje je zelo različno ... ZELO, zelo različno. In potem se seveda prilagajajo. Večina se prilagodi najnižjemu nivoju znanja, ne.«

Smiselno bi torej bilo, da bi pri uvodnem razgovoru sodelovati tudi učitelji, ki bi dejansko lahko sooblikovali posameznikov OIN, saj bi lahko bili pri njegovem uresničevanju zaradi svoje motivacijske vloge ključni akterji.

Vpliv osebnega izobraževalnega načrta na izvajanje izobraževalnega programa Prilagajanje programa izobraževanja posamezniku glede na njegov osebni izobraževalninačrt 
Večina organizatorjev/vodij izobraževanja odraslih na izbranih institucijah (7 I \%) odgovarja, da enkrat letno z udeleženci izobraževanja odraslih opravijo evalvacijski razgovor, kjer vrednotijo ustreznost izvedbe izobraževanja glede na načrte, zapisane v OIN. Nekateri organizatorji/vodje evalvacijski razgovor $\mathrm{z}$ udeleženci opravijo dvakrat letno (23,5\%), kar $6 \%$ pa nikoli.

Tabela 17: Pogostost razgovorov z udeleženci izobraževanja odraslih glede osebnih izobraževalnih načrtov

\begin{tabular}{|l|c|c|}
\hline Odgovori & Frekvenca & Odstotek \\
\hline I (nikoli) & $\mathrm{I}$ & $5.9 \%$ \\
\hline 2 (enkrat na leto) & $\mathrm{I} 2$ & $70.6 \%$ \\
\hline 3 (dvakrat na leto) & 4 & $23.5 \%$ \\
\hline 4 (več kot dvakrat na leto) & 0 & $0.0 \%$ \\
\hline Skupaj & $\mathrm{I}$ & $100.0 \%$ \\
\hline
\end{tabular}

Organizatorje/vodje izobraževanja odraslih smo vprašali, ali se potek in izvajanje izobraževanja prilagaja potrebam posameznika, ki so opredeljene v OIN. Največji delež anketirancev ( $56 \%$ ) meni, da se izobraževanje v veliki meri prilagaja potrebam posameznika, še vedno pa jih tretjina meni, da se to zgodi le v manjši meri. Vsi organizatorji/vodje izobraževanja odraslih pa navajajo, da v primeru težav pri uresničevanju OIN med letom pripravijo ustrezne spremembe OIN.

\section{Vloga in pomen osebnega izobraževalnega načrta za kakovost izobraževalnega procesa}

Zanimalo nas je, kako organizatorji/vodje izobraževanja odraslih ocenjujejo vlogo OIN. Dobre tri četrtine vprašanih $(76,5 \%)$ meni, da priprava OIN prispeva k večji kakovosti izobraževalnega procesa, medtem ko jih kar slaba četrtina $(23,5 \%)$ meni, da priprava OIN ne izboljša kakovosti izobraževalnega procesa. Zanimivi so razlogi vprašanih, ki so pogosto povsem nasprotujoči in kažejo na zelo različno razumevanje vloge organizatorjev izobraževanja, zlasti pa vloge OIN pri motiviranju udeležencev za uspešno izobraževanje.

Organizatorji/vodje izobraževanja odraslih, ki menijo, da OIN prispeva h kakovosti izobraževalnega procesa, to utemeljujejo z dejstvom, da OIN tako izvajalcem kot udeležencem izobraževanja omogoča večji nadzor nad procesom, spremljanje napredka in ugo- 
tavljanje močnih in šibkih področij odraslega udeleženca izobraževanja. Anketirance smo nadalje vprašali, v kakšne namene uporabljajo OIN. Glede na njihove odgovore vidimo, da ga vidijo zlasti kot sredstvo za lažje načrtovanje izobraževalne poti udeležencev oz. kot sredstvo za organizacijo učnega procesa udeležencev ter sredstvo za uspešnejše načrtovanje in večjo kakovost procesa poučevanja, manj pa kot motivacijsko sredstvo, sredstvo za vrednotenje formalnih in neformalnih izkušenj ali pa možnost za izboljšanje kakovosti učnega procesa.

Organizatorji/vodje izobraževanja odraslih v odprtih vprašanjih poudarjajo tudi vlogo OIN kot pomoč posameznikom pri organiziranju in načrtovanju izobraževanja, kot dejavnik motiviranja, pojavi pa se tudi mnenje, da že opažajo »manjši osip in večjo uspešnost udeležencev pri izpeljavi načrtovanega izobraževanja

To ponazarjajo sledeči odgovori:

»Kandidatu pomaga pri njegovem študiju, nam pa pri organizaciji dela.« »Udeležencem je to nek kažipot skozi celo šolsko leto, katere izpite morajo opraviti.« »OIN prispeva k večji preglednosti za udeležence in zaposlene. Na hiter način omogoča vpogled v potek izobraževanja udeleženca.«

»Opažamo manjši osip in večjo uspešnost udeležencev pri izpeljavi načrtovanega izobraževanja.«

Po drugi strani pa organizatorji/vodje izobraževanja odraslih, ki menijo, da OIN ne prispeva $\mathrm{k}$ izboljšanju kakovosti izobraževalnega procesa, za to navajajo zlasti naslednje razloge: preveč dela za organizatorje in majhen (ali celo negativen) učinek na udeležence; negativen odnos udeležencev do OIN zaradi dodatnih obveznosti in občutek, da so s podpisom OIN obvezani k izpolnjevanju obveznosti in nadzirani s strani izobraževalne organizacije. Sorazmerno velik delež organizatorjev izobraževanja OIN razume le kot birokratsko zahtevo, ki je sama sebi namen.

To dokazujejo izjave več anketiranih organizatorjev/vodij izobraževanja odraslih:

»Na kakovost izobraževalnega procesa to ne vpliva. Ta je odvisna od drugih dejavnikov (učitelji, prostor, informiranost, razpoložljivo gradivo ...). Osebni načrt pa je labko v pomoć posamezniku za redno spremljanje izvedbenega predmetnika in pravoćasno opravljanje obveznosti. Nekateri udeleženci ga žal sprejmejo kot nebodigatreba papir, ki služi šoli in ne njemu.«

»Že dosedaj smo počeli vse to ... ubija nas papirologija, OIN ima najmanj 3 strani, tu so š vloga za priznavanje, zapis uvodnega pogovora, zapisniki komisije za pri- 
znavanje, sklep o priznavanju ... ogromno papirologije. Mislim, da smo zašli. V redni šli izdelajo OIN samo za problematične učence, pri nas pa za vse; ali so vsi naši udeleženci problematični?«

$\gg$ Zbrane podatke smo v preteklosti zajeli že v sklepih o izobraževanju, izvedbenem predmetniku in $v$ letnem delovnem načrtu, o čemer smo kandidate po vpisih v programe tudi seznanjali. $Z$ izdelavo osebnega izobraževalnega načrta je organizatorjem izobraževanja naloženo dodatno administrativno delo, ki ga največkrat ne uspemo opraviti pravočasno.«

»Samo veliko dela, ki nima učinka oz. vrednosti. Ukvarjamo se s papirologijo in ne več s tem, kako kvalitetno izobraževati. Pomembno je, da dokumentacija ustre$z a$, nobenega pa ne zanima in se tudi ne preverja, če učitelj kvalitetno predava.«

Nekateri organizatorji/vodje izobraževanja odraslih so do priprave OIN ambivalentni - vidijo ga kot smiseln instrument, vendar le za nekatere udeležence. To dokazuje izjava:

»Nekateri udeleženci se ne želijo udeležiti priprave individualnega izobraževalnega načrta - sami si dovolj dobro organizirajo izobraževanje in ocenjujejo, da tega ne potrebujejo. Približno polovica kandidatov pa ocenjuje, da potrebujejo pomoč pri načrtovanju opravljanja svojih obveznosti, se udeležijo razgovora za pripravo individualnega izobraževalnega načrta in tudi pripravo ocenijo kot koristno, kot nekaj, kar jim bo pomagalo pri izobraževanju.«

Osebni izobraževalni načrt kot motivacijsko sredstvo Razumevanje osebnega izobraževalnega načrta kot motivacijkega sredstva za udeležence in izvajalce izobraževanja odraslih

$\mathrm{Na}$ vprašanje, ali menijo, da je osebni izobraževalni načrt pomemben kot motivacijsko sredstvo pri udeležencih izobraževanj, več kot polovica anketiranih organizatorjev/vodij izobraževanja odraslih $(62,5 \%)$ odgovarja, da je OIN pomembno motivacijsko sredstvo za odrasle udeležence izobraževanja. To mislijo zlasti anketiranci, ki OIN tudi sicer pozitivno ocenjujejo; kar precej anketirancev pa je do vloge OIN kritičnih.

Tisti, ki so mnenja, da je OIN motivacijsko sredstvo, pravijo, da le ta udeležencem izobraževanja predstavlja zemljevid izobraževanja, s katerim lahko sproti preverjajo, koliko so naredili in koliko so še oddaljeni od želenega cilja. V procesu natančno začrtane poti izobraževanja OIN predstavlja oporno točko za spretno vrednotenje lastnega uspeha. To ponazarja npr. tale izjava: 
»OIN predstavlja posamezniku zemljevid izobraževanja. Težo pridobi tudi s tem, ker ga sestavi skupaj z organizatorjem z največjo mero lastnega sodelovanja in upoštevanja individualnih potreb. V pripravi OIN dobi posameznik zanj potrebno osebno pozornost, hkrati pa tudi zaveznika, nekoga, ki bo bdel nad njim, kar mu daje dodaten občutek varnosti. OIN predstavlja tudi možnost sprotnega vrednotenja ob doseganju zastavljenih ciljev.«

Ali pa:

»Skupaj z udeležencem načrtujem število opravljenih izpitov. Prav tako udeleženec oceni svojo motivacijo za izobraževanje - koliko je pripravljen narediti za to, da bo uspešen (obiskovati priprave na izpite, govorilne ure ...), koliko se mu zdi pomembno, da dokonča izobraževanje.«

Tisti organizatorji/vodje izobraževanja odraslih, ki OIN ne vidijo kot motivacijsko sredstvo, pa navajajo odgovore:

»Udeleženci ga večinoma jemljejo kot še en papir, ki je namenjen šoli in ne njim.« $\gg$ Nisem opazila, da bi bil OIN motivacijsko sredstvo. Motivacija v večini primerov izhaja iz udeležencev samih, pripomorejo pa še: plačilo delodajalca, skupinska dinamika, uspeh pri izpitih ...«

»Udeležencem se ne zdi smiseln.«

»Udeleženec je motiviran ali ne, to nima nobene povezave z OIN oz. če nekatere ugotovitve vanj zapišemo.«

Kot vidimo, nekateri organizatorji/vodje izobraževanja odraslih menijo, da je težko soditi, koliko je OIN motivacijsko sredstvo, saj je to odvisno od vsakega posameznega udeleženca izobraževanja, spet drugi pa, da je to le »kos papirja več«, ki je namenjen šoli in ne posamezniku; ob tem nekateri dodajajo, da OIN nima nikakršnega vpliva na motivacijo in da udeleženci v njem ne vidijo nobenega smisla. Če nekoliko bolj celostno ovrednotimo odgovore anketiranih organizatorjev in vodij izobraževanja odraslih na srednjih poklicnih in strokovnih šolah, ugotovimo, da si na izobraževalnih institucijah sicer prizadevajo, da bi izobraževanje odraslim čim bolj prilagodili in upoštevali njihove potrebe, vendar pa jim to vedno ne uspeva, kar je posledica mnogih dejavnikov. Tako odgovori potrjujejo, da več kot polovici anketiranih organizatorjev izobraževanja odraslih priprava OIN predstavlja težavo, kar gotovo vpliva na kakovost dela in posledično na uspešnost ter zadovoljstvo udeležencev pri izobraževanju. 
Zanimalo pa nas je seveda tudi, kako vlogo OIN vidijo udeleženci izobraževanja odraslih, katerim naj bi OIN predstavljal motivacijsko sredstvo in pomoč pri organiziranju njihovega izobraževanja. Ugotovimo lahko, da večina odraslih udeležencev izobraževanja OIN ne namenja posebnega pomena. Na vprašanje, ali so zaradi priprave OIN za izobraževanje kaj bolj motivirani, odgovarjajo:

»Hmm ... ne vem, najbrž to bolj malo vpliva na moje učenje.«

Le približno petina intervjuvanih odraslih udeležencev izobraževanja (trinajst od dvainšestdesetih) je namreč izjavila, da jih OIN motivira, jim pomaga pri načrtovanju lastnega izobraževanja in ugotavljanju lastnega napredka. Ena od udeleženk je v tem smislu povedala, da ji je bil OIN dobra motivacija ter da ga je pogosto pregledovala. Pravi:

$\gg .$. ker vsakič ko sm jst to mojo razpredelnico mela pred sabo in po vsakem izpitu ... sem pršla domov za pisalno mizo in sem lepo mela moj plan izobraževanja in to mojo razpredelnico po predmetih. In vsak predmet, ki se je dopolnjeval, je nekako sestavljal te puzle, celotno sliko in ... vedla sm, kaj so moji cilji, ne ...«.

$\gg$ Po moje /je vloga OIN, op. Avtorji/predvsm orientacijska. Mogoč je na nek način motivacija.«

Nekaterim udeležencem izobraževanja OIN preprosto pomaga pri organizaciji dela:

»Ja, da si lažje opredelim učenje posameznih predmetov.«

Nekateri udeleženci izobraževanja samo pripravo OIN vidijo kot pomembno in smiselno dejavnost, ki jim pomaga strukturirati delo in vpliva na njihovo učenje. To utemeljujejo takole:

» Tako lažje delajo organizatorji izobraževanja, jaz lažje vem, kako uspešen sem, sledim izobraževanju

$\gg$ Mogoče. Vendar, če mi ga ne bi naredili na šoli, bi si ga verjetno naredil sam. Ker imam rad, da je vse urejeno in da vidim, kje sem. Drugače se izgubim in nimam več volje.«

»Ja, učim se to, kaj je napisano v osebnem izobraževalnem načrtu. Pa da vse sproti opravljam.«

Ugotavljamo, da so odgovori, ki pozitivno vrednotijo pripravo OIN in njegov učinek, povezani tudi z načinom priprave OIN; če je posameznik vpet v pripravo OIN, če sam dejavno sodeluje in sproti osmišlja cilje, zapisane v OIN, potem to tudi lahko uporabi kot vo- 
dič in motivacijsko sredstvo za lasten napredek v izobraževalnem procesu. Tam, kjer pa je OIN pripravljen bolj zato, da se zadosti predpisanim zahtevam, pa ima OIN malo vpliva na potek izobraževanja in uspešnost udeležencev.

\section{Vpliv osebnega izobraževalnega načrta na uspešnost odraslih pri učenju}

Odrasle udeležence izobraževanja smo tudi vprašali, ali OIN vpliva na uspešnost njihovega izobraževanja oz. ali vpliva na njihovo učenje. Večina intervjuvancev na to vprašanje odgovarja, da OIN ne vpliva na njihovo učenje oz. da ga v obliki, kakršna je, ne morejo uporabljati kot pomoč pri načrtovanju lastnega učenja. Na to vprašanje dve intervjuvanki odgovarjata:

$\gg$ Ne. Ne bi rekla.«

$\gg \mathrm{Ne}$, nima nobenega vpliva $\ll$.

$\gg \mathrm{Ne}$, učenje si po svoje prilagodim.«

Udeleženci izobraževanja navajajo, da OIN pogosto nimajo doma, temveč ga hranijo v izobraževalni instituciji, zaradi česar ga sproti ne morejo pregledovati in dopolnjevati. Nekateri navajajo, da OIN ni bil zasnovan ustrezno; vseboval je le seznam izpitov, ki jih je potrebno opraviti, in predviden rok za dokončanje, ne pa tudi načinov, kako doseči zastavljene cilje (npr. opraviti izpit), o čemer se tudi niso pogovarjali s svetovalko. Zaradi te vloge OIN so nekateri udeleženci celo rekli, da so pozabili, da OIN sploh imajo.

»Sploh pojma nimam. Prvič slišim za to.«

»Načrt majo oni, mi ga niso dal.«

Nekateri odrasli udeleženci izobraževanja navajajo, da si namesto OIN sami naredijo načrt, tudi cilje si zastavljajo sami, kar jih motivira. OIN ocenjujejo kot presplošen, v mnogih primerih ne dovolj prilagojen posamezniku, kar zmanjšuje njegovo uporabnost in ga postavlja v vlogo nepotrebnega dokumenta, ki je sam sebi v namen. Eden od udeležencev zapiše:

»Men osebno ne pomaga, verjamem pa, da kšnmu prov pride, ker se ne zna izobraževat «.

»Za nekatere mogoč kot vodilo, zame ne. Mislm, da OIN ni slab, ampak jz sem drgačna. Sm imela na listkih v pušcici napisane vse pomembne stvari, kaj bom nrdila, kdaj so izpitni roki in vse to. Načrt o svojem izobraževanju sm vodila, ampak ga nism napisala $v$ OIN.« 
Nekateri odrasli udeleženci izobraževanja, ki OIN-a sicer niso imeli, pa so menili, da bi bili pri učenju bolj uspešni, če bi imeli jasno in natančno opredeljeno, začrtano svojo izobraževalno pot in da bi jim OIN pri delu verjetno koristil. To ponazarja tale izjava:

»Ja bi, ker imaš neko motivacijo oz. preglednost nad svojim učenjem.«

Ugotovimo lahko, da je uspešnost načrtovanja izobraževanja s pomočjo OIN zelo odvisna od možnosti, ki obstajajo na institucijah za izobraževanje odraslih (število zaposlenih, organizacija dela, število študentov itd.), po drugi strani pa tudi od seznanjenosti odraslih udeležencev z vlogo OIN in pripravljenosti, da ga uporabijo za dejavno načrtovanje svoje izobraževalne poti.

O vplivu OIN na uspešnost odraslih pri izobraževanju smo v anketi vprašali tudi organizatorje/vodje izobraževanja odraslih. Več kot dve tretjini (70 \%) anketirancev meni, da OIN zmerno vpliva na udeleženčev uspešen zaključek izobraževanja, skoraj četrtina pa jih meni, da na njihovo uspešnost sploh ne vpliva. To pomeni, da OIN ocenjujejo kot dokument brez posebne vrednosti.

To vprašanje je smiselno tudi zaradi tega, ker organizatorji/vodje izobraževanja pri odraslih udeležencih izobraževanja zaznavajo kar precej težav, povezanih z uresničevanjem OIN, pa tudi mnogo drugih težav (situacijskih, institucijskih in dispozicijskih ovir), ki bi jih morda z ustreznim sprotnim zaznavanjem ter sprotnim reševanjem lažje obvladovali. Organizatorji izobraževanja odraslih pri udeležencih zaznavajo med drugim naslednje težave:

»Zaradi časovne stiske ne opravijo ali niso uspešni pri opravljanju kakšnega izpita, predvidenega vizobraževanem načrtu.«

$\gg$ Ne uspejo slediti obveznostim v izobraževalnem programu. To je posledica njihovih obveznosti iz delovnega razmerja, kaže pa se kot neredna udeležba na predavanjih in posledicno neopravljeni izpiti.«

»Največ je osebnih težav (družina, služba, denarne težave), zaradi česar udeleženci izpuščajo svoje obveznosti.«

\section{Ovire, skaterimi se soočajo udeleženci izobraževanja odraslih}

Zanimalo nas je, ali se udeleženci izobraževanja odraslih soočajo s kakšnimi težavami, problemi, zaradi katerih bi potrebovali dodatno pomoč s strani učiteljev, organizatorjev ali svetovalcev na izobraževalni instituciji. Da bi to ugotovili, smo jih v intervjujih povprašali, s katerimi ovirami se srečujejo in kako jih rešujejo. Večina udeležencev nava- 
ja, da se v procesu izobraževanja sooča z različnimi ovirami, kar ponazarja nekaj izjav intervjuvancev:

>Pomanjkanje prostega časa, preveliki stroški za izobraževanje. Moram plačat vsak izpit. Ne znam si organizirat časa za učenje, imam tudi kdaj težave s koncentracijo.«

》Učitelji niso takšni, kot sem pričakoval. Na pamet se moraš učit. Imam težave pri učenju s koncentracijo in zapomnitvijo. Ne da se mi, to je.«

» Ja, predvsem zaradi starosti. Že nekaj časa je minilo, odkar sem hodila $v$ šolo. Težko je preklopit nazaj. Težko je bilo začeti.«

»Se z družino ne vidimo skoraj nič, razen za vikend. Jaz delam ponoči zaradi šolanja, da lahko pridem sem. Delovni čas se mi zaradi tega ne prilagaja. Je malo naporno, ja. Na začetku sem imel težave s koncentracijo, ko si toliko ven iz tega. Prvi mesec, dva, zdaj pa ne, ni problema več.«

Nekateri udeleženci so trdili, da se ne soočajo z ovirami oz. da kakšen manjši problem uspešno premagajo, a v nadaljnjem pogovoru se je včasih izkazalo, da temu ni povsem tako.

$\gg$ Ne soočam se z nobeno od ovir. Problem so kakšni učitelji, ker so res nesramni. Tud use v razredu tretirajo enak. Tretirajo ns kot Is-letnike.«

»Program ni prezahteven, star nisem, organizirati se znam. Prostega časa mi manjka, ampak se znam organizirati. Družinske obveznosti tudi včasih znajo biti problem. Učitelji so prva liga, drugih problemov ne vidim.«

»Nimam ovir; da sem ponovno šla v šolo, je bila moja želja in bi tudi rada napredovala. Drugače pa mi je pomagal starejši sin pri matematiki.«

Redki udeleženci izobraževanja pa ovir ne občutijo in to jasno povedo:

»Nism imela nič od navedenih težav in ovir. Je teklo vse gladko.«

» Imam čas, družine nimam, rada se učim.«

»Ne, na ovire pa nisem naletel. Družine še nimam, zveza s punco zaradi šole ne trpi, ona študira v Ljubljani, tak da se med tednom tak ne vidima kaj dosti, kraj izobraževanja je itak mesto, v katerem živim, stroške tega šolanja pa mi (na srečo, hehe) pokrijejo starši.«

Ko smo odrasle udeležence izobraževanja vprašali, kako se soočajo z ovirami, kako jih premagujejo oz. ali jim pri tem kdo pomaga ter kako, jih večina pravi, da težave večinoma 
rešujejo sami ali s pomočjo družine, in sicer na zelo različne načine. V obrazložitev navajajo:

»Naredim si urnik, ki se ga držim. Učim se, ko sin spi ali je v vrtcu. Moji starši so čez dan v službi, tako da sam poskrbim za naju s sinom. Najpomembneje je, da se znam organizirati. Torej, pomembna je disciplina.«

»Pomagam si sam, pa tud žena, tko da je ona mal več z otrokom, da se jst lahk učim.«

$\gg$ Moj mož in otroci mi stojijo ob strani in mi tudi pomagajo.«

$\gg$ Meni zelo pomagajo starši od žene predvsem pri varstvu. Oba z ženo imava tako službo, da morajo starši veliko paziti otroke.«

»Družina se je stem sprijaznila in mi nudi podporo, tudi zato, ker upajo na boljše delovno mesto in delo $v$ eni izmeni in proste vikende, kar bi vsem bolj odgovarjalo in se zavedajo, da bi po zaključenem šolanju imel tudi za njib več prostega časa in prosti čas čez vikende; pa tudi v službi se da zmenit, da ko so izpiti in predavanja, po potrebi zamenjam smeno. Res so razumevajocii.«

Vidimo, da se odrasli udeleženci izobraževanja soočajo z mnogimi ovirami v procesu izobraževanja, kar kaže na veliko potrebo po stalni in učinkoviti podpori in pomoči s strani izvajalcev izobraževanja odraslih. Poleg podpornih dejavnosti, kot so npr. možnosti informiranja ali svetovanja v svetovalnih središčih, bi bilo nujno potrebno vzpostaviti tudi učinkovitejši sistem spremljanja napredka in pomoči posamezniku na njegovi izobraževalni poti. Ena od motivacijskih možnosti, ki zdaj ni ustrezno izkoriščena, bi lahko bil tudi OIN.

\section{Ovrednotenje uresničevanja osebnih izobraževalnih načrtov}

Težave in ovire organizatorjev izobraževanja pri uresničevanju osebnega izobraževalnega načrta

Več kot polovica ( $56 \%$ ) organizatorjev/vodij izobraževanja odraslih na izbranih izobraževalnih institucijah odgovarja, da jim priprava OIN predstavlja določene težave in pri uvajanju OIN zaznavajo različne ovire. Najpogosteje kot težavo navajajo pomanjkanje časa, nekateri pa tudi veliko število udeležencev izobraževanja glede na majhno število zaposlenih andragoških delavcev, kar otežuje ustrezno pripravo OIN in sprotno vrednotenje poteka izobraževanja odraslih udeležencev. Nekateri anketiranci navajajo, da prevzamejo vse vloge sami in da so zaradi tega zelo obremenjeni. To dokazujeta npr. izjavi: 
»Pripravim ga /OIN, op. avtorjev/ sama na osnovi uvodnega razgovora z udeležencem; $v$ času vpisa je to veliko breme, saj je treba pravoćasno uskladiti urnik (s profesorji, drugimi skupinami na isti soli, časounim planom, izvedbenim predmetnikom,

letnim delovnim načrtom ......«

»Jaz pripravim predloge OIN-a in opravim tudi razgovor z udeleženci.«

Predvidevamo, da je preobremenjenost zaposlenih zlasti posledica stalnega pomanjkanja kadrov na področju izobraževanja odraslih, posledica pa je neustrezna organizacija dela. Organizatorji/vodje izobraževanja odraslih navajajo tudi, da udeleženci izobraževanja OIN ne jemljejo resno; organizatorji izobraževanja zato procesu priprave OIN posvetijo premalo energije in pozornosti, ga ne uporabljajo kot inštrument za samopreverjanje uspešnosti udeležencev skozi šolsko leto in OIN razumejo zlasti kot zakonsko zahtevo.

Eden od anketiranih organizatorjev izobraževanja odraslih je izpostavil, da lahko kvaliteten OIN z udeležencem pripravi le oseba, ki dobro pozna udeleženca in sistem, ocenjuje pa, da je takih - vsaj v njihovi organizaciji za izobraževanje odraslih -, premalo. Anketiranci sicer navajajo, da pri sestavi OIN največkrat sodeluje organizator izobraževanja (tako je odgovorilo $94 \%$ vprašanih), nekateri pa k pripravi vključijo tudi svetovalca (25\%). Ta podatek govori o tem, da so drugi zaposleni, ki na izvajalski organizaciji udeležencem lahko pomagajo pri uresničevanju zastavljenih ciljev (npr. učitelji), malo vpeti v pripravo OIN.

Organizatorje/vodje izobraževanja odraslih smo tudi vprašali, ali menijo, da so dovolj dobro strokovno podkovani za pripravo, izvedbo in spremljanje osebnega izobraževalnega načrta udeležencev. Več kot polovica (59\%) jih meni, da so ustrezno usposobljeni, skoraj četrtina pa jih ne ve, kako bi se odločili.

$\mathrm{V}$ nadaljevanju smo organizatorje/vodje izobraževanja odraslih tudi vprašali, ali je v pogojih, v katerih delajo, po njihovem mnenju priprava OIN smiselna. Več kot polovica ( $53 \%$ ) anketirancev meni, da je priprava OIN smiselna, odgovori pa kažejo, da predvsem zaradi spremljanja izobraževalne poti in za načrtovanje izobraževanja ter zaradi izboljšanja kakovosti izobraževanja, kar še zlasti velja za izobraževanje po individualnem modelu. Pomanjkanje časa in preobsežna administrativna dela pa lahko zasenčijo smiselnost priprave OIN-a. V ilustracijo navajamo nekaj razlogov, ki jih izpostavljajo anketirani organizatorji izobraževanja:

»Smiselna je zaradi neuspešnih udeležencev, ki več let poskušajo z izobraževanjem - velik problem je vpis zaradi pridobitve statusa za studentsko delo. Ko se po letu ali dveh vrnejo, pride osebni načrt prav za lažje načrtovanje nadaljnjega izobraževanja.« 
»Smiselna je priprava OIN za resne udeležence izobraževanja.«

»Izobraževanje izvajamo po individualnem modelu, brez predavanj, z organiziranimi konzultacijami in govorilnimi urami. Ustrezna organizacija opravljanja izpitov je zato za posameznika ključnega pomena. Nekateri so tukaj zelo uspešni, drugi se ne znajdejo - za te je priprava OIN še posebej pomembna in smiselna.«

»Čeprav je zaradi mnogih administrativnih obveznosti vedno problem s časom, je izdelava OIN do neke mere smiselna in obvezuje tako organizatorja kot udeleženca izobraževanja odraslib k izpolnjevanju in korigiranju načrtovanega«.

Da pa pri pripravi OIN ni vse tako, kot bi moralo biti, pa nakazujejo tudi odgovori skoraj tretjine $(29 \%)$ anketiranih organizatorjev/vodij izobraževanja odraslih, ki menijo, da priprava OIN v danih pogojih ni smiselna. Taka stališča potrjujejo nekatere izjave:

»Delovni pogoji za pripravo OIN niso ustrezni, z vidika udeleženca in same kvalitete izobraževanja pa je priprava OIN smiselna in potrebna.«

$\gg$ ».. v praksi se ga skoraj ne upošteva. Kdo se pa labko ukvarja z vsemi željami udeležencev? Podobno je pri odprtem kurikulu in izbirnih predmetih. Ta ni odprt in tudi predmeti niso izbirni. Je postalo enako, kot je bilo nekoč - fiksni predmetnik. To delamo zato, da smo enotni in da imamo vsaj manj težav s priznavanjem ocen drugih izobraževalnih ustanov.«

Eden izmed OIN nenaklonjenih anketirancev torej meni, da se OIN v praksi ne uporablja, saj je nemogoče upoštevati želje vseh udeležencev; dodaja, da je predmetnik dokaj nespremenljiv, kar institucijam onemogoča, da udeležencem priznavajo na drugih institucijah že opravljene obveznosti.

Predlogi organizatorjev izobraževanja glede osebnih izobraževalnih načrtov

Organizatorje/vodje izobraževanja odraslih, ki so odgovarjali na anketni vprašalnik, smo ob koncu anketiranja prosili, da predstavijo tudi svoje poglede na uresničevanje OIN, o katerih jih nismo vprašali. Do priprave OIN so bili kar kritični; opozarjali so na zahtevne pogoje dela ob zmanjševanju financiranja in pomanjkanju kadra, zlasti pa na zahteve, ki izhajajo iz zakonodaje, pa v praksi v danih razmerah niso uresničljive tako, da bi to prispevalo h kakovostnemu delu. Dali so naslednje izjave:

»Pri pripravljanju pravilnikov za področje izobraževanja odraslih je potrebno upoštevati razmere na tem področju - predvsem kadrovsko zasedbo in stopnjo izo- 
brazbe. S postavljanjem nemogočih zabtev se samo spravlja zaposlene v stisko, doseže sepa nič!!! Da se naloži 300 ur dodatnega dela na leto (priprava načrta za vsakega udeleženca in spremljanje - vpisanih imamo 300 udeležencev) brez analize, kdo bo to delal in kako?? Treba je omogociti pogoje, da se bo to labko izvajalo! Omogočiti je potrebno sistemizacijo novih delovnih mest, zagotoviti sredstva in usposobiti kadre.« »Preveč tega je za povedati. Na kratko: zakonodaja ne upošteva specifik izobraževanja odraslih, vse se poskuša vkalupiti v šolski sistem, ogromno birokracije, imenovanj svetovalcev, vodij področij itd. ... vse pa tako ali tako opravlja isti človek.«

»Če že mora obstajati OIN, bi bilo v redu, da obstaja fiksni obrazec za posamezni program in da ga potem, če že moramo, izpolnimo. Sedaj si pač vsaka ustanova po svoje nekaj sestavi, da ga vsaj ima. Tako kot so prišle ocene nazaj, pravila ocenjevanja, napredovanje v višji letnik ... bo mogoče kdo spravil OIN na največ 3 strani in bo vsem zadovoljeno. $\ll$

»Strokovne inštitucije, ki se ukvarjajo z navodili o izobraževanju odraslih, niso povezane med seboj. Tako se določene aktivnosti ponavljajo...«

»OIN je koristen in potreben le za udeležence, ki ga potrebujejo in jim bo koristil pri njihovemu izobraževanju.«

V ponazoritev navajamo še nekaj odgovorov organizatorjev/vodij izobraževanja odraslih, ki vsebujejo tudi že konkretne predloge za izboljšanje stanja:

»Veliko preobširna dokumentacija, ki naj bi jo bilo potrebno izpolniti ob pripravi OIN - to ocenjujem kot nekoristno in nesmiselno ob pomanjkanju kadra. V vsakem primeru je na področju izobraževanja odraslib veliko preveč birokracije - če bi želeli imeti urejeno dokumentacijo, bi se labko ukvarjali samo še stem. Kajpa delo z ljudmi?? Popolnoma neživljenjsko. Predlagam poenostavitev postopkov in dokumentacije in enotno dokumentacijo za celo Slovenijo (enostavno) - en model za skupinsko izobraževanje in en model za individualne vključitve! «

»Mislim, da je potrebno pripraviti osebni izobraževalni načrt le za udeležence, ki se resnično nameravajo izobraževati in ne za vse vpisane udeležence. Tu mislim predvsem na tiste, ki se vpisujejo le zaradi statusa. Težava je v tem, da je zelo težko priti v ponovni stik s kandidati, ki jih zanima le status. Druga težava pa je v realizaciji tega. Po mojih izkušnjah gre za pripravo enega osebnega izobraževalnega načrta od 45 do 60 minut, če je udeležencev 300 , je to ogromno časa, ki ga je v praksi 
težko najti. Dober osebni izobraževalni načrt lahko z udeležencem pripravi le oseba, ki udeleženca dobro pozna, to pa je na šoli ponavadi le ena oseba, ki pa ji zmanjka časa za pripravo vseh osebnih izobraževalnih načrtov.«

»Premajhno število zaposlenih v organizacijah za izobraževanje odraslih, velik naval v parih dneh pred pričetkom, saj niti ne vemo, kakšno skupino imamo, dokler se udeleženci ne vpišejo, vpisati se nočejo, dokler ne vedo, kaj imajo priznano, mi pa jim tega ne moremo povedati, dokler o njihovih vlogah ne odloči komisija ... grozno je vse zbirokratizirano. Zakon in pravilnik ne poznata zakonitosti izobraževanja odraslih. Mi februarja ali marca ne vemo, kdo se bo k nam vpisal, saj se vecina odraslih pri nas oglaša konec avgusta in začetek septembra, $v$ času POM in priprav na začetek leta.« »Največ težav je z realizacijo načrtovanega, saj se odraslim zelo spreminjajo življenjski pogoji - večina jih nima stalne zaposlitve, ustvarjajo si družine in urejajo stanovanjska vprašanja. Zato je OIN potrebno stalno spreminjat, dopolnjevat ...« $\gg$ Največja težava je pomanjkanje časa, kajti priprava OIN za vsakega udeleženca ti vzame res veliko časa in tiskanje ter kopiranje vseh dokumentov res ni ekološko naravnano. Pri nas smo OIN na nek način že izvajali, se pogovorili z vsakim udeležencem o poteku izobraževanja, le zapisali nismo tega.«

\section{Sklepne ugotovitve in predlogi}

Velika večina anketiranih organizatorjev izobraževanja je seznanjena z določbami zakona o poklicnem in strokovnem izobraževanju. Navodila o prilagajanju izrednega poklicnega in strokovnega izobraževanja, ki opredeljujejo vsebino in način priprave osebnega izobraževalnega načrta, organizatorji izobraževanja odraslih v večjem deležu upoštevajo. Tisti, ki navodila upoštevajo le delno, navajajo težave s pomanjkanjem časa in kadra.

Analiza odgovorov organizatorjev izobraževanja je pokazala, da osebni izobraževalni načrt za celotno šolsko leto pripravijo v vseh ustanovah, vključenih v raziskavo. Odgovori intervjuvanih udeležencev na enako vprašanje se razlikujejo; tretjina jih je izjavila, da nimajo osebnega izobraževalnega načrta, nekateri med njimi so med intervjujem zanj prvič slišali. Osebni izobraževalni načrt na anketiranih izobraževalnih institucijah večinoma pripravljajo skupaj z udeležencem, vendar obstajajo razlike glede na način in obseg sodelovanja. Nekateri osebni izobraževalni načrt pripravljajo individualno, z vsakim udeležencem posebej, drugi pa kombinirajo skupinsko in individualno pripravo. V manjši meri organizatorji izobraževanja odraslih sami pripravijo osebni izobraževalni načrt za udeleženca in ga z njim le seznanijo. Po potrebi pa ga med šolskim letom ustrezno prilagajajo. 
Iz odgovorov anketiranih organizatorjev izobraževanja lahko vidimo, da v osebni izobraževalni načrt najpogosteje vključijo podatke o zaključenem predhodnem formalnem izobraževanju vključno z morebitnimi posebnostmi, podatke o predvidenem vsebinskem in časovnem poteku izobraževanja, podatke o načinih in rokih preverjanja znanja, podatke o formalnih in neformalnih delovnih in drugih izkušnjah (kvalifikacijah) kandidata ter podatke o poteku in časovnih rokih za spremljanje uresničevanja osebnega izobraževalnega načrta, ostali podatki pa se v povprečju uporabljajo v manjši meri. Nekateri organizatorji v osebni izobraževalni načrt vključijo še celotni načrt obveznosti in posebej letni načrt obveznosti, delovni status, delovne izkušnje, pričakovanja o izobraževanju, ovire, spodbude in priložnosti za izobraževanje, cilje, motivacijo, opombe organizatorja. O zagotavljanju obveznih individualnih ali skupinskih konzultacij ( 5 ur) se večina ni opredelila, kot tudi ne o pomoči pri dostopanju do ustreznih učnih virov. Večina intervjuvanih udeležencev, ki imajo svoj osebni izobraževalni načrt, meni, da njegovo vsebino pozna, toda na konkretnejša vprašanja o vsebini so njihovi odgovori dokaj nejasni.

$\mathrm{Na}$ splošno izvajalci izobraževanja odraslih navodila v večji meri upoštevajo pri individualizirani obliki izobraževalnega modela, manj pa pri skupinskih oblikah, kjer je veliko število udeležencev. Iz odgovorov organizatorjev izobraževanja pa lahko razberemo, da mnogi osebni izobraževalni načrt pripravljajo predvsem zato, da zadostijo Zakonu o poklicnem in strokovnem izobraževanju, torej kot formalnost, ki jo je potrebno izpolniti in ki zahteva dodatno administrativno delo, sicer pa se nekateri med njimi sploh zavedajo pravega smisla in namena osebnega izobraževalnega načrta.

Večina anketiranih organizatorjev izobraževanja pridobiva mnenje udeležencev o ustreznosti izvedbe izobraževanja glede na njihove osebne izobraževalne načrte vsaj enkrat, nekateri tudi dvakrat letno, so pa tudi takšni, ki tega ne počnejo. Navodila o prilagajanju izrednega poklicnega in strokovnega izobraževanja namreč določajo, da se evalvacijski razgovor opravi vsaj enkrat letno, kar pomeni, da organizatorji izobraževanja v tem pogledu v veliki meri upoštevajo zakonska določila.

Po izjavah nekaj več kot polovice organizatorjev izobraževanja v njihovih organizacijah program izobraževanja prilagajajo potrebam posameznika, vendar je še vedno velik odstotek tistih, ki to upoštevajo v manjši meri ali pa sploh ne. Večina udeležencev pa po drugi strani trdi, da teh prilagoditev ni oziroma da ne vedo, ali jih na izobraževalni instituciji izvajajo.

Organizatorji izobraževanja opozarjajo na problem prilagajanja pri udeležencih izobraževanja, ki so se vpisali že pred časom. Ker se v vmesnem času spreminja izobraževalni 
program, je za takšne udeležence potrebno pripraviti nov osebni izobraževalni načrt. Sicer pa imajo udeleženci izobraževanja možnost prilagojenega opravljanja obveznosti, kar pomeni, da nekateri hitreje opravijo izpite, kot je predvideno v njihovem osebnem izobraževalnem načrtu, tistim, ki jim je tempo prehiter, pa dovoljujejo opravljanje obveznosti počasnejše, kot je bilo prvotno načrtovano.

Analiza odgovorov organizatorjev izobraževanja je pokazala, da se uresničevanje sprejetega izvedbenega načrta za učno skupino in uresničevanje osebnih izobraževalnih načrtov $\mathrm{v}$ večji meri spremlja preko evalvacijskih pogovorov $\mathrm{z}$ udeleženci in učitelji. Če se pri evalvacijskem pogovoru pokažejo težave pri uresničevanju načrta, se ustrezne spremembe osebnih izobraževalnih načrtov pripravijo med letom. Koliko oz. ali se izvedbeni načrt za učno skupino prilagaja med letom (npr. dodatne aktivnosti v smislu pomoči), iz analize vprašalnikov ni razvidno. Primerjava odgovorov udeležencev pokaže, da večina ne ve veliko o prilagajanju, medtem ko vsi, ki imajo svoj osebni izobraževalni načrt, izjavlja, da se ta načrt med njihovim izobraževanjem ni spreminjal.

Rezultati analize anketnega vprašalnika so pokazali, da pri uvodnem razgovoru nikoli ne sodelujejo učitelji. Informiranost učiteljev o vlogi in pomenu osebnega izobraževalnega načrta je večinoma skromna. To pa pomeni, da učitelj težko pripomore k uresničevanju osebnega izobraževalnega načrta, če ga sploh ne pozna in ni seznanjen s posebnostmi in potrebami udeležencev. Približno polovica organizatorjev se v okviru evalvacijskega pogovora enkrat ali dvakrat na leto posvetuje z učitelji o ustreznosti osebnega izobraževalnega načrta za posameznega udeleženca izobraževanja. To pomeni, da le polovica učiteljev upošteva navodila o prilagajanju izrednega poklicnega in strokovnega izobraževanja, ki opredeljujejo vsebino in način priprave osebnega izobraževalnega načrta. Ta podatek ni spodbuden, saj so učitelji nosilci izobraževalnih vsebin po predmetih in so v neposrednem kontaktu z udeleženci. Ali je vzrok v pomanjkanju kadra ali pa so problemi drugje, je težko odgovoriti. Vsekakor bi bilo potrebno na tem področju storiti več, saj strokovnjaki opozarjajo na pomembno vlogo učitelja, ki naj bi pomagal pripraviti osebni izobraževalni načrt (za predmet, katerega nosilec je), pomagal odraslemu pri spremljanju njegovega izobraževanja glede na oblikovani osebni izobraževalni načrt in pri končnem vrednotenju, kaj je pri posameznem predmetu dosegel. In ne nazadnje je osebni izobraževalni načrt za učitelja lahko tudi pripomoček za lažje načrtovanje dela v skupinah ter vrednotenje lastnega dela. Na vprašanje, ali se z učitelji posvetujejo in pogovarjajo o uresničevanju svojega osebnega izobraževalnega načrta, so vsi odrasli udeleženci poklicnega in strokovnega izobraževanja odgovorili negativno. Po mnenju mnogih intervjuvancev je večina učiteljev 
v učnem procesu sicer pripravljena pomagati, če se pojavijo težave, vendar pa ta pomoč nikoli ni povezana $z$ doseganjem ciljev in uresničevanjem zahtev, zapisanih v osebnem izobraževalnem načrtu, temveč je vezana na pomoč pri učnih urah in tekom izobraževalnega procesa.

Organizatorji izobraževanja osebni izobraževalni načrt v veliki meri vidijo kot motivacijsko sredstvo za udeležence izobraževanja. Kvalitetno pripravljen osebni izobraževalni načrt lahko udeležencu služi kot oporna točka, saj lahko vidi cilj in to, kako se mu približuje. Pomembno pa je tudi, da osebni izobraževalni načrt udeleženec sestavi skupaj z organizatorjem, saj se le tako lahko upoštevajo njegove individualne potrebe. Rezultati analize so pokazali, da osebni izobraževalni načrt kot motivacijsko sredstvo za udeležence predstavlja začrtano pot izobraževanja in omogoča sprotno evalvacijo. To motivira tudi določen odstotek izvajalcev, saj se s tem potrjuje njihova ustrezna priprava osebnega izobraževalnega načrta. Ti izvajalci oz. organizatorji izobraževanja hkrati ocenjujejo, da priprava in izvajanje osebnega izobraževalnega načrta prispeva $\mathrm{k}$ večji kakovosti izobraževalnega procesa, kar lahko predstavlja pomembno motivacijsko sredstvo.

Po mnenju nekaterih organizatorjev del udeležencev izobraževanja osebni izobraževalni načrt dojema kot le še en papir, ki je namenjen šoli in ne njim, in v teh primerih ga gotovo ne doživljajo kot motivacijo pri svojem izobraževanju. V določeni meri je to lahko posledica nerazumevanja ali negativnega pristopa organizatorja $\mathrm{k}$ razumevanju osebnega izobraževalnega načrta.

Podatki ankete so pokazali, da kar za polovico organizatorjev izobraževanja priprava in izvajanje osebnega izobraževalnega načrta ne predstavljata motivacijskega sredstva, ampak prej težavo. Analiza intervjujev pokaže, da večine odraslih udeležencev izobraževanja osebni izobraževalni načrt posebno ne motivira. Ugotavljamo, da so odgovori udeležencev, ki pozitivno vrednotijo svoj osebni izobraževalni načrt in njegov učinek, povezani z načinom priprave načrta; če je posameznik vpet v pripravo osebnega izobraževalnega načrta, če sam dejavno sodeluje in sproti osmišlja cilje, zapisane v osebnem izobraževalnem načrtu, potem to običajno uporabi kot vodnik in motivacijsko sredstvo za lasten napredek v izobraževalnem procesu. Tam, kjer je osebni izobraževalni načrt pripravljen bolj zato, da se zadosti predpisanim zahtevam, osebni izobraževalni načrt ne motivira in ne vpliva na potek izobraževanja in uspešnost udeležencev.

Kot navajajo strokovnjaki, se udeleženci izobraževanja pri uresničevanju osebnega izobraževalnega načrta soočajo z različnimi ovirami, ki jih lahko razdelimo v situacijske, sistemske in dispozicijske ovire; $\mathrm{z}$ njimi se glede na interakcijo v izobraževalnem procesu 
sooča tudi organizator izobraževanja. Analiza intervjujev kaže, da se odrasli udeleženci izobraževanja v procesu izobraževanja soočajo z mnogimi ovirami. Največkrat naštevajo situacijske ovire (pomanjkanje časa, družinske obveznosti, previsoki stroški izobraževanja in oddaljenost kraja izobraževanja), nekoliko manj dispozicijske (težave s koncentracijo, lenoba, starost), nekaj pa jih omenja tudi institucionalne ovire (neustrezen čas izobraževanja, izobraževanje ni organizirano v skladu z osebnim izobraževalnim načrtom, pomanjkljivo sestavljen osebni izobraževalni načrt). Večino teh težav skušajo reševati sami ali s pomočjo družine.

Po mnenju organizatorjev izobraževanja se težave pri uresničevanju osebnega izobraževalnega načrta kažejo v pomanjkljivi motivaciji udeležencev, ki je posledica številnih osebnih ovir, kot so družinske obveznosti, pomanjkanje časa, služba, bolezen, materinstvo, oddaljenost ipd., kar jih odvrača od doslednega sledenja svojemu izobraževalnemu načrtu.

Med sedemnajstimi anketiranimi izobraževalnimi organizacijami se na devetih soočajo $s$ težavami pri pripravi in izvedbi osebnega izobraževalnega načrta. Največ anketiranih ima težave zaradi pomanjkanja časa in prevelikega števila kandidatov za izredno poklicno in strokovno izobraževanje. Priprava osebnega izobraževalnega načrta običajno poteka skupaj z vpisom, kar pomeni, da se naenkrat na instituciji pojavi ogromno število novih kandidatov, in v takšnih razmerah sami organizatorji (praviloma v eni osebi) ne utegnejo nameniti dovolj pozornosti vsakemu posamezniku, zmanjka jim časa za kakovostno individualno obravnavo. Zaradi velikega števila vpisanih organizatorji ne morejo sami poskrbeti, da bodo imeli vsi udeleženci kakovostno narejen osebni izobraževalni načrt.

Kot pogoste težave pri uresničevanju osebnega izobraževalnega načrta organizatorji izobraževanja navajajo še pomanjkanje strokovne usposobljenosti ostalega zaposlenega osebja, premalo praktičnih izkušenj na tem področju, premalo ustreznega kadra, preveliko zapletenost izpeljave celotnega postopka, preveč administrativnega oz. birokratskega dela, številčnost in raznovrstnost programov itd.

Veliko anketiranih je bilo mnenja, da je težava v administraciji oziroma birokraciji, saj se osebni izobraževalni načrt pripravlja zgolj zato, ker ga je potrebno imeti, če ne drugače, pa zaradi inšpekcije. So tudi mnenja, da je osebni izobraževalni načrt težko oblikovati, ker se nekateri udeleženci vpišejo samo zaradi statusa. Prepričani so, da je udeleženca potrebno res zelo dobro poznati, da bi zanj lahko pripravil kvaliteten izobraževalni načrt. Prav tako je po mnenju organizatorjev izobraževanja na njihovih institucijah zaposlenih premalo ljudi, ki bi dobro poznali vsebino navodil o prilagajanju izrednega poklicnega in strokovnega izobraževanja. 
Kot opozarjajo strokovnjaki, je le ustrezno usposobljen strokovni delavec oz. svetovalec, ki pozna temeljne značilnosti učenja odraslih in njihove posebnosti pri učenju, ki obvlada spretnosti svetovalnega dela in postopke za izdelavo različnih osebnih izobraževalnih načrtov, njihovo spremljanje in evalvacijo, možnosti za izpeljavo izobraževanja v različnih organizacijskih oblikah itn., lahko v vsestransko pomoč udeležencu pri pripravi in izvedbi njegovega osebnega izobraževalnega načrta. Strokovna usposobljenost organizatorja izobraževanja je zelo pomembna, saj je ta nekakšen svetovalec udeležencu. Pomaga mu pri načrtovanju ciljev, prav tako pa mu mora biti tudi za oporo in pomoč med samim doseganjem ciljev. Strokovna usposobljenost se vidi predvsem takrat, kadar udeležencu ne gre vse po načrtih in mu je potrebno pomagati in spremeniti cilje.

Dobra polovica organizatorjev izobraževanja v naši anketi je mnenja, da so ustrezno strokovno podkovani za pripravo, izvedbo in spremljanje osebnega izobraževalnega načrta udeležencev. Glede na relativno velik delež tistih, ki se do tega vprašanja niso opredelili, predpostavljamo, da imajo pomanjkljiva znanja in informacije o pomenu in uporabnosti osebnega izobraževalnega načrta in bi potrebovali dodatno izobraževanje in usposabljanje na tem področju.

Osebni izobraževalni načrt bi bil veliko bolj motivacijsko sestavljen, če bi organizatorji izobraževanja imeli dovolj časa, da bi se lahko posvetili samo enemu udeležencu in z njim naredili kvaliteten načrt. Tako bi z udeležencem lahko naredila načrt, kako do cilja s čim več motivacije. Udeleženec bi bil veliko bolj motiviran za izobraževanje, če bi videl dejansko uporabnost svojega izobraževalnega načrta.

Po mnenju organizatorjev izobraževanja bi osebni izobraževalni načrt lahko postal motivacijsko sredstvo, če bi na njihovih izobraževalnih institucijah povečali število zaposlenega osebja ter ga ustrezno strokovno usposobili za pripravo in spremljanje osebnih izobraževalnih načrtov vseh udeležencev izobraževanja. Prav tako pa bi bilo potrebno udeležence izobraževanja podrobno seznaniti z namenom in uporabnostjo osebnega izobraževalnega načrta. Morda bi tako zmanjšali delež tistih udeležencev, ki v osebnem izobraževalnem načrtu ne vidijo posebnega smisla. Rednejše spremljanje osebnega izobraževalnega načrta bi lahko bila dodatna spodbuda za udeležence. Vendar je pri tem potrebno upoštevati, da samo dobra priprava osebnega izobraževalnega načrta ni zadosten pogoj za uspešno motivacijo. Posamezni komentarji v vprašalniku nakazujejo, da bi večja povezanost strokovnih institucij s področja izobraževanja odraslih, nova sistemizacija delovnih mest, usposabljanje kadrov, zagotavljanje več sredstev in zmanjšanje administrativnih del verjetno prav tako pripomogli, da bi osebni izobraževalni načrt postal ustrezno motivacijsko sredstvo. 
Pri udeležencih in tudi izvajalcih izobraževanja bi moralo priti do miselnega premika o tem, da je namen osebnega izobraževalnega načrta pomoč udeležencu, ne pa formalistična papirologija. Pripravljen mora biti na podlagi udeleženčevih interesov, potreb in zmožnosti. Strokovno podkovan in ustrezno usposobljen strokovni delavec, ki dobro pozna udeleženca, je lahko pri tem v veliko pomoč in motivacijo. Po mnenju anketiranih bo osebni izobraževalni načrt postal ustrezno motivacijsko sredstvo, če ga bo udeleženec izobraževanja sprejel za svojega. Šele takrat bosta strokovni delavec in udeleženec skupaj spremljala uresničevanje dogovorov ter skupaj evalvirala rezultate.

Poleg naštetega pa bi bilo potrebno spremeniti tudi organizacijo in izvedbo izobraževalnega procesa (manjše število udeležencev, večje število učiteljev in organizatorjev izobraževanja odraslih idr.), kar bi vključevalo tudi spremenjeno vlogo učiteljev v učnem procesu, uporabo drugačnih metod poučevanja, drugačen način spremljanja učnih dosežkov, uvajati bi bilo potrebno različne podporne dejavnosti (andragoško svetovalno delo, skupinska in individualna učna pomoč ipd.), skratka na različne načine poskrbeti za to, da osebni izobraževalni načrt ne bi bil le dodatno breme za organizatorje izobraževanja in »nekakšen papir« za udeležence.

Da bi osebni izobraževalni načrt dejansko postal motivacijsko sredstvo, bi bilo potrebno upoštevati naslednje predloge, ki jo jih podali organizatorji izobraževanja odraslih in odrasli udeleženci izrednega poklicnega in strokovnega izobraževanja, med katerimi izpostavljamo najbolj pogoste:

- boljša seznanjenost vseh sodelujočih o vlogi in pomenu osebnega izobraževalnega načrta

- večja povezanost strokovnih institucij s področja izobraževanja odraslih

- enoten obrazec za pripravo osebnega izobraževalnega načrta

- standardizirati postopka priprave osebnega izobraževalnega načrta

- nova sistemizacija delovnih mest

- usposobitev dodatne kadre

- vključitev učiteljev v pripravo, izvedbo in doseganje ciljev osebnega izobraževalnega načrta

- zagotovitev več sredstev

- zmanjšanje birokracijo

- uvedba opcijo, da se osebni izobraževalni načrt pripravi samo za udeležence, ki ga dejansko potrebujejo

- v večji meri upoštevanje želja, potreb, pričakovanj in zmožnosti udeležencev 
- prilagoditev osebnega izobraževalnega načrta posamezniku

- obvezno sodelovanje udeležencev pri pripravi njihovega osebnega izobraževalnega načrta

- redno spremljanje, evalvacija uresničevanja osebnega izobraževalnega načrta

- pri priznavanju predhodnih znanj upoštevanje tudi neformalno pridobljena znanja

- zagotovitev, da vsak udeleženec izobraževanja dobi kopijo svojega osebnega izobraževalnega načrta

- oblikovanje osebnega izobraževalnega načrta, ki naj vključuje priznavanje predhodno pridobljenega znanja, cilje, vsebine in časovni potek izobraževanja ter načine preverjanja znanja

Za zaključek lahko ugotovimo, da ima zasnova osebnega izobraževalnega načrta v izobraževanje odraslih po eni strani izvore v psiholoških teorijah motivacije, po drugi pa tudi v samih andragoških načelih, ki v ospredje postavljajo avtonomnost, sodelovanje in aktivno vlogo odraslega pri svojem izobraževanju. Prav tako ugotavljamo, da je osebni izobraževalni načrt lahko uporabno motivacijsko sredstvo tako za udeležence kot za organizatorje izobraževanja in učitelje pri načrtovanju izobraževalnih aktivnosti in doseganju zastavljenih ciljev, vendar pa v sedanji izobraževalni praksi to motivacijsko sredstvo še ni dovolj izkoriščeno. Opažamo namreč, da se osebni izobraževalni načrt v premajhnem deležu uporablja kot motivacijsko sredstvo in da tu obstajajo še neizkoriščene rezerve tako za udeležence kot organizatorje izobraževanja. Priprava osebnega izobraževalnega načrta je ena od oblik pomoči, s katero izobraževalci na različne načine spodbudijo in podprejo učenje posameznikov, npr. pri posredovanju ustreznih informacij in njihovem presojanju, pri zbujanju ali ohranjanju motivacije za učenje, pri vrednotenju napredovanja posameznika v skladu z njegovim izobraževalnim načrtom. Toda glede na rezultate naše raziskave je na tem področju potrebno še veliko seznanjanja in angažiranosti tako izvajalcev kot odraslih udeležencev izobraževanja.

\section{Literatura}

Anderson, G., Boud, D. in Sampson, J. (1996). Learning contracts: A practical guide.

London: Kogan Page.

Atherton, J. S. (2011). Teaching and learning; Learning contracts. Dostopno na spletni strani: http://www.learningandteaching.info/teaching/learningcontracts.htm Austin, J. T. in Vancouver, J. B. (1996). Goal constructs in psychology: Structure, process and content. Psychological Bulletin, 120 (3), 338-375. 
Bandura, A. (1997). Self-efficacy: The exercise of control. New York: Freeman.

Bandura, A. in Schunk, D. H. (1981). Cultivating competence, self-efficacy, and intrinsic interest through proximal self-motivation. Journal of Personality and Social Psychology, 41, 586-598.

Boeren, E., Nicaise, I. in Baert, H. (2010). Theoretical models of participation in adult education: The need for an integrated model. International Journal of Lifelong Education, 29 (1), 45-61.

Bonnell, J. M. in Caffarella, R. S. (1991). Learning contracts. V M. W. Galbraith (ur.), Adult learning methods: A guide for effective instruction. (str. 133-160). Malabar, FL: Krieger Publishing Company.

Boshier, R. (1973). Educational participation and dropout: A theoretical model. Adult Education, 23 (4), 255-282.

Brockett, R. G. in Hiemstra, R. (1991). Self-direction in adult learning: Perspectives on theory, research, and practice. New York: Routledge.

Brookfield, S. (1985). Self-directed learning: A critical review of research. New Directions for Adult and Continuing Education, 25, 5-16.

Candy, P. C. (1991). Self-direction for lifelong learning: A comprehensive guide to theory and practice. San Francisco: Jossey-Bass.

Cross, K. P. (1981). Adults as learners: Increasing participation and facilitating learning. San Francisco: Jossey-Bass.

Deci, E. L. in Ryan, R. M. (1985). Intrinsic motivation and self-determination in human behavior. New York: Plenum Press.

Deci, E. L. in Ryan, R. M. (2012). Self-determination theory. V P. A. M. Van Lange, A. W. Kruglanski in E. T. Higgins (ur.), Handbook of theories of social psychology: Vol. 1 (str. 416-437). Thousand Oaks, CA: Sage.

Glaser, B. G. in Strauss, A. (1967). The discovery of grounded theory: Strategies for qualitative research. Chicago, IL: Aldine Publishing Co.

Houle, C. O. (1993). The inquiring mind (3. izd.). Norman: Oklahoma Research Center for Continuing Professional and Higher Education. (Prva izdaja leta 1961).

Justinek, A., Kokalj, B. Levec, A., Lukan, D., Markovič, S., Pal, P. in Praznik, I. (2010). Osebni izobraževalni načrt. Ljubljana: Center za poklicno izobraževanje.

Klemenčič, S. (2004). Zakaj načrtovati izobraževanje in učenje? V M. Velikonja (ur.), Osebni izobraževalni načrt (str. 9-25). Ljubljana: Andragoški center Slovenije.

Knowles, M. S. (1975). Self-directed learning. A guide for learners and teachers. Englewood Cliffs: Cambridge Adult Education. 
Knowles, M. S. (1991). Using learning contracts. San Francisco: Jossey-Bass.

Locke, E. A. in Latham, G. P. (1990). A theory of goal setting and task performance. Englewood Cliffs, NJ: Prentice-Hall.

Mesec, B. (1998). Uvod v kvalitativno raziskovanje v socialnem delu. Ljubljana: Visoka šola za socialno delo.

Miller, H. L. (1967). Participation of adults in education, A force-field analysis. MA, Brookline: Center for the Study of Liberal Education for Adults.

Možina, T. (2004). Vrste osebnih izobraževalnih načrtov. V Velikonja M. (ur.), Osebni izobraževalni načrt (str. 55-65). Ljubljana: Andragoški center Slovenije.

Navodila o prilagajanju izrednega poklicnega in strokovnega izobraževanja. (2008). Uradni list RS, št. 8/2008. Dostopno na spletni strani: http://zakonodaja.gov.si/rpsi/ r04/predpis_NAVO914.html

Navodila o prilagajanju izrednega poklicnega in strokovnega izobraževanja. (2008). Uradni list RS, št. 8/2008. Dostopno na spletni strani: http://zakonodaja.gov.si/rpsi/ r04/predpis_NAVO914.html

O'Donnell, J. M. in Caffarella, R. S. (1991). Learning contracts. V M. W. Galbraith (ur.), Adult learning methods: A guide for effective instruction (str. 133-160). Malabar, FL: Krieger Publishing Company.

Pintrich, P. R. (1989). The dynamic interplay of student motivation and cognition in the college classroom. V M. L. Maehr in P. R. Pintrich (ur.), Advances in motivation and achievement, Vol. 6 (str. 117-160). Greenwich CT: JAI press.

Pintrich, P. R. in Garcia, T. (1991). Student goal orientation and self-regulation in the college classroom. V M. L. Maehr in P. R. Pintrich (ur.), Advances in motivation and achievement: A research annual, Vol. 7 (str. 371-402). Greenwich, CT: JAI Press.

Quigley, B. A. (1997). Rethinking literacy education: The critical need for practice-based change. San Francisco: Jossey-Bass.

Rubenson, K. (1987). Participation in recurrent education: A research review. V H. G. Schütze in D. Istance (ur.), Recurrent education revisited: Modes of participation and financing (str. 39-67). Stockholm: Almqvist \& Wiksell International.

Schunk, D. H. (1991). Self-efficacy and academic motivation. Educational Psychologist, 26, 207-231.

Strauss, A. in Corbin, J. (1990). Basic of qualitative research: Grounded theory procedures and techniques. Newbury Park: Sage Publications.

Tough, A. (1979). The adult's learning projects (2. izd.). Toronto: Ontario Institute for Studies in Education. 
Wlodkowski, R. J. (2008). Enhancing adult motivation to learn: A comprehensive guide for teaching all adults (3rd. ed.). San Francisco: Jossey-Bass.

Zakon o poklicnem in strokovnem izobraževanju ZPSI-1 (2006). Ur.l. RS, št. 79/2006. Dostopno na spletni strani: http://www.uradni-list.si/1/objava. jsp?urlid=200679\&stevilka=3449 (20.2. 2011)

Zimmerman, B. J. (2002). Becoming a self-regulated learner: An overview. Theory Into Practice, 41 (2), 64-70.

Zimmerman, B. J. in Martinez-Pons, M. (1990). Student differences in self-regulated learning: Relating grade, sex, and giftedness to self-efficacy and strategy use. Journal of Educational Psychology, 82 (1), 51-59.

Žalec, N. (2004). Oblikovanje osebnega izobraževalnega načrta. V M. Velikonja (ur.), Osebni izobraževalni načrt (str. 120-129). Ljubljana: Andragoški center Slovenije.

Žalec, N. (2004). Spremljanje in vrednotenje osebnega izobraževalnega načrta. V M. Velikonja (ur.), Osebni izobraževalni načrt (str. 66-104). Ljubljana: Andragoški center Slovenije. 


\section{Povzetek}

V monografiji Motivacija v izobraževanju mladine in odraslih predstavljamo tri neodvisne študije, ki so bile izvedene v okviru evalvacijske študije »Motivacijski dejavniki v izobraževanju mladine in odraslih« (2010-2012).

V prvem poglavju z naslovom Motivacijski dejavniki bralnih dosežkov v raziskavi PISA 2009 avtorice Melita Puklek Levpušček, Anja Podlesek in Klaudija Šterman Ivančič predstavljajo sekundarne analize motivacijskih, socialnih in učnih dejavnikov bralne pismenosti. V prvi fazi raziskave so avtorice izvedle primerjalno analizo bralnih aktivnosti, motivacije za branje, učnih strategij ter značilnosti učnega okolja. V raziskavi PISA 2009 so rezultate slovenskih Is-letnikov pri omenjenih dejavnikih bralne pismenosti primerjale z rezultati njihovih vrstnikov v dveh visoko uspešnih evropskih državah, tj. Finski in Norveški. V drugi fazi raziskave so avtorice ugotavljale tipične profile slovenskih dijakov glede na značilnosti njihove bralne motivacije ter učnih in metakognitivnih strategij pri branju besedil $v$ raziskavi PISA 2009 . V zadnji fazi raziskave so avtorice ugotavljale pomen motivacijskih dejavnikov v različnih izobraževalnih programih in po spolu. Primerjalna analiza je pokazala naslednje bistvene izsledke: a) pri slovenskih mladostnikih je nadpovprečno prisotna zunanja motivacija za branje, pa tudi odpor do branja, manj je prisotno uživanje $\mathrm{v}$ branju; b) učne strategije elaboracije naučenega in strategije nadzora nad razumevanjem prebranega so pri slovenskih I5-letnikih dokaj dobro zastopane, dijaki na Norveškem in Finskem pa zaznavajo večjo pomembnost in uporabnost učinkovitih strategij povzemanja besedila kot dijaki v Sloveniji; c) čeprav je povprečna vrednost indeksa discipline v razredu v Sloveniji nižja, kot je ta na ravni povprečja OECD, pa je na Finskem in Norveškem disciplina v razredu še slabša; č) slovenski I 5 -letniki zaznavajo več učiteljeve spodbude pri pouku materinščine kot njihovi vrstniki v obeh skandinavskih državah; d) slovenski dijaki v 
povprečju zaznavajo manj pozitiven odnos učiteljev do njih, kot je to ugotovljeno na Finskem in Norveškem. V nadaljevanju so avtorice $\mathrm{z}$ dvostopenjsko klastrsko analizo dijake uvrstile v pet klastrov glede na značilnosti njihove bralne motivacije ter učnih in metakognitivnih strategij pri branju besedil. Na reprezentativnem vzorcu slovenskih is-letnikov lahko sklepamo, da je v Sloveniji približno $40 \%$ takih dijakov, ki so zavzeti bralci ter imajo dobro razvite učne in metakognitivne strategije. Kar tri skupine mladih bralcev (okoli $60 \%)$ pa opredeljuje nezavzeto branje, kar še enkrat potrjuje dejstvo, da so slovenski dijaki v povprečju nizko motivirani bralci. Motivacijski vidiki bralne pismenosti so v največji meri prisotni pri dijakih splošnih gimnazij, nato pa bralna motivacija upada z nižanjem zahtevnostne ravni izobraževalnih programov. Pomembna močna področja deklet, ki doprinašajo $k$ njihovi boljši bralni pismenosti, so večja bralna angažiranost, pogostejše branje literarnih besedil in besedil v tiskani obliki, pogostejša interpretacija bralnih tekstov, prav tako je pomembno, da pozitivneje zaznavajo spodbude učitelja $\mathrm{k}$ branju kot fantje. Primerjalna prednost fantov pri spodbujanju bralne pismenosti je njihova motiviranost in zaznana kompetentnost pri delu z IKT. Besedilo avtorice zaključujejo s splošno diskusijo in pedagoškimi implikacijami rezultatov.

V drugem poglavju z naslovom Povezanost med motivacijo za izobraževanje, tekmovalnostjo in različnimi področji samopodobe pri študentih se avtorji Darja Kobal Grum, Janez Kolenc in Manca Seničar osredotočajo na motivacijo za izobraževanje in tekmovalnost pri študentih. Motivacija in tekmovalnost sta v okviru izobraževanja zelo pomembna dejavnika, ki se zrcalita v izbiri poklica, učni uspešnosti in kasnejši delovni karieri posameznika. Avtorje je zanimalo, kakšna je povezanost med motivacijo za izobraževanje, tekmovalnostnimi naravnanostmi in različnimi vidiki samospoštovanja, v okviru tega pa so preučili tudi motivacijo za tekmovalnost ter odnos med omenjenimi konstrukti in psihološkimi dimenzijami, kot so čustva in temeljne psihične potrebe. V raziskavo so vključili večji vzorec slovenskih študentov različnih študijskih smeri, ki so izpolnili sklop vprašalnikov, med katerimi so bile lestvice motivacije, tekmovalnosti in temeljnih potreb ter vprašalniki samospoštovanja, pozitivne in negativne emocionalnosti. Rezultati so pokazali, da med udeleženci obstajajo pomembne razlike glede na spol in področje izobraževanja (humanistika in družboslovje oz. naravoslovje in tehnika), in sicer na področju motivacije za izobraževanje, hipertekmovalnosti in motivacije za tekmovalnost, pa tudi v zadovoljenosti temeljnih psihičnih potreb in samospoštovanju. Ugotovitve raziskave poudarjajo pomembnost spodbujanja intrinzične motivacije in tekmovalnosti v smislu osebnega razvoja posameznika ter na ta način služijo kot načela za oblikovanje študijskega procesa. 
Naslov tretjega poglavja je Motivacija v izobraževanju odraslih. V njem avtorji Marko Radovan, Sabina Jelenc Krašovec in Sonja Kump predstavljajo vlogo osebnega izobraževalnega načrta (OIN) pri povečevanju uspešnosti odraslih v poklicnem in strokovnem izobraževanju v Sloveniji. $Z$ anketnimi vprašalniki in kvalitativnimi intervjuji so avtorji analizirali mnenja organizatorjev in vodij izbranih institucij, ki izvajajo izredno poklicno in strokovno izobraževanje odraslih ter odraslih udeležencev izobraževanja v teh programih. Zanimala jih je priprava in uresničevanje OIN, kdo sodeluje v tem procesu, kakšna je vloga OIN v procesu izobraževanja in s kakšnimi ovirami se v izobraževalnih organizacijah pri tem srečujejo. Avtorji so ugotavljali tudi stališča odraslih udeležencev poklicnega in strokovnega izobraževanja glede priprave OIN in njegovega izvajanja; zanimali so jih njihovo doživljanje tega instrumenta kot motivacijskega dejavnika in kot dejavnika zmanjševanja ovir, ki jih doživljajo v procesu izobraževanja. Ugotovili so, da se pri pripravi OIN pojavlja veliko težav, tako na strani organizatorjev in izvajalcev izobraževanja kot tudi na strani udeležencev izobraževanja. Vzroki za to so zlasti pomanjkanje kadra, ki bi poskrbel za ustrezno pripravo in izvedbo OIN, pomanjkanje časa za pripravo OIN in drugih strukturnih možnosti, ki preprečujejo ustrezno načrtovanje izobraževalnega procesa v skladu z OIN. Tudi udeleženci večinoma ugotavljajo, da OIN v obliki, v kakršni se uporablja danes, večinama ni motivacijsko sredstvo in spodbuda za uspešnejše izobraževanje in učenje. 



\section{Summary}

In the monograph Motivation in Youth and Adult Education we present three independent studies carried out as part of the evaluation study Motivation factors in Youth and Adult Education (2010-2012).

In the first chapter Motivation factors in reading achievements in the PISA 2009 research authors Melita Puklek Levpušček, Anja Podlesek and Klaudija Šterman Ivančič present secondary analyses of motivational, social and learning factors in reading literacy. In the first stage of the research the authors conducted a comparative analysis of reading activities, motivation for reading, learning strategies and characteristics of the learning environment. They compared results of Slovenian I5-year-olds in the above mentioned factors of reading literacy with results of their peers in two highly successful European countries in the PISA 2009 research, Finland and Norway. In the second stage of the research the authors identified typical profiles of Slovenian students according to the characteristics of their reading motivation and metacognitive strategies in text reading in the PISA 2009 research. In the last stage of the research the authors established the importance of motivational factors in different education programmes and according to gender. The comparative analysis has shown the following key results:

a) Slovenian youngsters have an exceptional external motivation for reading; they are also reluctant to reading; they do not truly enjoy reading.

b) Learning strategies of elaborating the learned material and strategies of control over the understanding of read material are quite present with Slovenian 15 -yearolds; however for Norwegian and Finnish students the effective strategies of summarising seem to be more important and useful as for Slovenian students. 
c) The discipline index in Slovenian classes is lower than the average index of the OECD, however in Finland and Norway it is even lower.

d) Slovenian 15-year-olds feel that there is more encouragement from teachers in mother tongue class than their peers in both Scandinavian countries do.

e) Slovenian students on average feel there is a less positive attitude from teachers than students in Finland and Norway do.

The authors then performed a two-level cluster analysis and classified the students in five clusters according to the characteristics of their reading motivation and learning and metacognitive strategies in reading texts. Based on the representative sample of Slovenian 15 -year-olds we can conclude that there are approximately $40 \%$ of Slovenian students that are enthusiastic readers and have good learning and metacognitive strategies. As much as three groups of young readers (approximately $60 \%$ ) are half-hearted readers. This only proves the fact that Slovenian students are on average not motivated to read. Motivational aspects of reading literacy are mostly present in students of general secondary grammar schools. Motivation for reading drops gradually with lower level education programmes. Girls contribute to better reading literacy as they are highly motivated to read, more often than not they read literary texts and printed texts, they interpret texts, and what is also important, they react more positively to teachers' reading stimulations. Boys also have comparative advantages, as they are motivated and competent in working with ICT. The authors close the monograph with a general discussion and pedagogic suppositions on results.

In the second chapter The Connection Between motivation for Education, Competitiveness and Different Fields of Student Self-image the authors Darja Kobal Grum, Janez Kolenc and Manca Seničar concentrate on motivation for education and competitiveness in university students. Motivation and competitiveness are very important factors in education that reflect in career choice, learning success and later career of every individual. We wanted to investigate the connection between motivation for education, competitiveness and different aspects of self-respect. At the same time we studied motivation for competitiveness and the relationship between the abovementioned constructs with psychological dimensions, such as emotions and fundamental mental needs. We included in the research a larger sample of Slovenian students from different studying courses. They filled in a set of questionnaires, including motivation scales, competitiveness scales and fundamental needs scales, and also questionnaires on self-respect and positive and negative emotionality. The results have shown that there are significant differences depending on gender 
and field of education (social sciences and humanities vs. natural sciences and engineering). The differences can be seen in the fields of motivation for education, hyper competitiveness and motivation for competitiveness, but also in the satisfaction of fundamental mental needs and self-respect. These findings emphasise the importance of stimulating intrinsic motivation and competitiveness as part of the personal development of an individual and they function as principles for developing the studying process.

The third chapter is Motivation in Adult Education. In this chapter authors Marko Radovan, Sabina Jelenc Krašovec and Sonja Kump present the role of the personal education plan (PEP) in increasing the performance of adults in vocational and technical education in Slovenia. The survey questionnaire and analysis of qualitative interviews were used to analyse opinions of organizers and leaders of selected institutions providing vocational and technical programmes for adult learners and opinions of adult participants in such programmes. The authors were interested in the preparation and realization of PEP, who participates in this process, the role of PEP in the educational process and what obstacles educational institutions face. They also examined opinions of adult participants in vocational and technical education programmes about the preparation and implementation of PEP; they were interested in their experience with this instrument as a motivational factor and its influence in reducing the obstacles they encounter in the process of education. They found out that a lot of problems occur in the process of preparing PEP, both on the part of organizers and education as well as the learners. The reasons for this are mainly lack of human resources to ensure the proper preparation and execution of PEP, lack of time to prepare PEP and other structural circumstances that prevent proper planning of the educational process in accordance with PEP. Participants as well generally recognize that PEP in the form in which it is used today, is generally not such a good motivational tool and an incentive for better education and learning as it was planned to be. 



\section{Imensko in stvarno kazalo}

A

Abend, T. 129, 147

Ainley, M.D. 124, 146

Akande, A. 122, 151

Anderman, E. M. 146

Anderman, L. H. 67, 112, 115

Anderson, C. A. 129, 148, 162, 197

Areepattamannil, S. 143, 146

Avsec, A. 128, 148

avtonomnost 23, 108, 119, 120, 121, 123, 130, 138, 155, 156, 157, 162, 197

B

Baard, P. P. 129, 146

Bajc, K. 112

Baker, L. 21, 24, 25, 44, 111

Barton, M. L. 25, 108, 112

Baumeister, R. F. 129, 146

Baumgardner, A. H. 128, 146

Berry, A. J. 147, 148

Blais, M. R. 117, 130, 151

Boekaerts, M. 28, 53, 111

Bonnell, J. M. 198
Borges del Rosal, A. 143, 146

bralna pismenost 33, 97, 104, 106

bralni dosežki 45, 49, 70, 85, 100, 105

bralni profili 72, 104, 105

branje za šolo 92

branje za zabavo 86

Briere, N. M. 117, 130

Brockett, R. G. 160, 161, 198

Brookfield, S. 161, 198

Brown, D. J. 112, 125, 131, 147, 149

Bryk, A.S. 113

Bucik, N. 22, 25

C

Caffarella, R. S. 198, 199

Cairney, J. 128, 149

Callahan, S. 131, 146

Candy, P. C. 161,198

Chabrol, H. 131, 146

Cheong, Y. 113

Clark, L. A. 151

Cleary, T. J. 28, 53, 114

Cohen, J. 111, 150 
Congdon, R. 113

Connell, J. P. 118, 119, 146, 150

Corbin, J. 166, 199

Cunningham, A. E. 25, 111

$\check{C}$

Čad, S. 42, 111

čustva 130, 136, 142, 202

Deci, E. L. 117, 119, 120, 121, 123, 126, 129 , $146,147,148,149,150,151,156,157$, 198

De Groot, E. V. 28, 113, 157

družboslovje in humanistika 136

Dumas, F. 113

Dweck, C. S. 122, 147

E

ekstrinzična motivacija 116, 117, 121, 123, 130, 141, 143

elaboracijske in organizacijske strategije 29, 30

Elias, H. 143, 148

Entwistle, N. J. 32, 111

Epstein, J. L. 116, 147

Eurydice Slovenija 43, 111

F

Fekonja, U. 135, 151

Flavell, J. H. 29, 111

Franken, R. E. 125, 131, 147

Freeman, J.G. 143, 146, 198
$G$

Gagne, M. 130

Gamoran 61, 63, 67

Glaser, B. G. 166, 198

Gold, J. A. 126, 131, 150

Goldman, B. 148

Goldman, B. M. 148

Goldman, S. R. 53, 111, 128, 131

Gonzalez Sierra, M. A. 143, 146

Gradišar, A. 22, 23, 26, 28, 31

Greenier, K. D. 129, 147, 148

Griffin-Pierson, S. 126, 147

Gril, A. 6

Grolnick, W. S. 119, 121, 147, 150

Guthrie, J. T. 21, 22, 23, 24, 25, 26, 27, 108, 111

$H$

Hamann, E. T. 21, 25, 26, 27, 108, 112

Hammer, M. 126, 130, 131, 150

Harackiewicz, J. M. 124, 127, 148, 149, 150

Harter, S. 116, 147

Herlocker, C. E. 147, 148

Hernandez-Jorge, C. M. 143, 146

Hidi, S. 124, 147, 148

Hiemstra, R. 16o, 161, 198

hipertekmovalnost 126, 131, 143

Houle, C. O. 153, 160, 163, 198

Houston, J. M. 125, 150

Hubner, J. J. 150

Hume, L. M. 30, 31

Hume. L. M. 113 
Ilardi, B. C. 129, 148

indeks dejavnosti branja na spletu 52

indeks discipline v razredu 61

indeks različnosti bralnega gradiva 48, 72

indeks uživanja v branju 46, 101

indeks zaznane učiteljeve spodbude 60 ,

$$
63,74
$$

intrinzična motivacija 116, 118, 121, 123,

$$
\text { 130, } 145
$$

Irvin, J. L. 27, 111

izobraževalne ovire 184, 186, 191, 193

izobraževalni program 18, 33, 85, 86, 87, 96, 105, 154, 174, 192

izobraževanje odraslih $34,35,156,164$, $165,166,167,184,187,190,197,203$

K

Kaczor, L. M. 126, 131, 150

Kasser, T. 119, 148, 150

Kaufman, C. M. 146

Kavčič, T. 135, 151

Kernis, M. H. 128, 129, 131, 147, 148, 149, 151

Kjaernsli, M. 42, 112

Klemenčič, S. 159, 198

Klinger, D. A. 143, 146

Knowles, M. S. 159, 160, 161, 198, 199

Kobal Grum, D. 18, 115, 128, 131, 148, 202, 206

Kolenc, J. 18, 115, 148, 202, 206

kompetentnost 22, 46, 110, 116, 119, 120, $127,128,130,138,144,145,202$
Krapp, A. 124, 148, 150

Kunda, Z. 128, 148

L

Lebarič, N. 131, 148

Leone, D. 148

Levy, P. E. 146

Lewis, J. 30, 112

Lončarič, D. 29, 112

Loose, F. 113

M

Maehr, M. L. 115, 116, 146, 199

Mahyuddin, R. 143, 148

Marentič Požarnik, B. 28, 112

Marjanovič Umek, L. 112, 151

Markelj, N. 105, 113

Markus, H. R. 70, 128, 148

Marsh, H. W. 116, 124, 148, 149

McCombs, B. L. 25, 108, 112

McInerney, D. M. 124, 149

McMenniman, M. 116, 149

McMullin, J. A. 128, 149

McPartland, J. M. 116, 147

Meltzer, J. 21, 25, 26, 27, 108, 112

metakognitivne strategije $28,30,37,54$, 77, 81, 84, 86, 97, 100, 104, 105, 106, 110, 157, 202

Miserandino, M. 119, 149

mladostništvo 115

motivacija za branje 22, 31, 81, 101, 104, 201

motivacija za izobraževanje $18,115,124$, 130, 140, 141, 143, 145, 181, 202 
motivacijski dejavniki 17, 21, 201

Mullins, E. R. 27, 111

Murdock, T. B. 67, 112

Musek, J. 127, 149

Myers, M. R. 116, 148

N

naravoslovje in tehnika 136, 202

nestabilnost samospoštovanja 130

Niemiec, C. P. 119, 149

Noordin, N. 143, 148

OECD 17, 24, 25, 26, 28, 31, 32, 33, 38, 40, $41,42,43,44,45,46,47,49,50,51,52$, $53,54,55,56,58,59,60,61,62,63,64$, $65,66,67,68,70,71,82,86,87,90,91$, $92,93,94,95,100,101,103,106,107$, 108, 109, 110, 112, 113, 201, 206

osebna tekmovalnost 138

osebni izobraževalni načrt 18, 159, 162, $163,164,165,166,167,168,169,171$, $172,173,174,175,176,177,178,179$, $180,181,182,183,184,186,187,188$, 189, 190, 203

osip 132, 179

Owens, L. 116, 148

P

Paradise, A. W. 128

Pečjak, S. 21, 22, 23, 24, 25, 26, 27, 28, 31, 113

Peklaj, C. 22, 29, 30, 112, 113

Pelletier, L. G. 117, 130, 151
Pintrich, P. R. 28, 32, 115, 149, 157, 199

Podlesek, A. 17, 37, 113, 201, 205

pogojenost samospoštovanja 131, 136, 140

poklicno izobraževanje $41,75,85,91,198$

pouk slovenščine $35,36,65,86$

povezanost 130

pravice 6

psihične potrebe 130, 138, 202

Puklek Levpušček, M. 17, 37, 67, 113, 201, 205

R

Race, P. 123, 141, 149

Rakestraw, J. A. 53, 111

Ramsden, P. 32, 111

Raudenbush, S. W. 113

ravni bralne pismenosti 38, 40, 79, 105

raziskava PISA 33

Reeve, J. 126, 149

Regner, I. 67, 113

Renninger, K. A. 124, 149

rezultati raziskave PISA 60

Riskind, J. H. 125, 149

Roche, J. H. 149

Roche, L. 124

Roe, A. 42, 112

Rosenberg, M. 128, 149

Rousseau, A. 131, 146

Rubenson, K. 154, 199

Ryan, R. M. 117, 118, 119, 120, 121, 123, 129, $138,146,147,148,149,150,156,198$

Ryckman, R. M. 126, 130, 131, 150 
S

samopodoba 115, 127, 143, 155

samospoštovanje $116,125,128,129,131$,

133, 136, 139, 143

samostojno učenje odraslih 160

samougajanje 128, 131, 143

Schiefele, U. 46, 101, 113, 124, 150

Schrauben, B. 32, 113

Schunk, D. H. 115, 149, 198, 199

Senecal, C. B. 130

Shavelson, R. J. 128, 150

Sheldon, K. M. 119, 150

Smither, R. 125, 150

Smith, I. D. 116,148

socialno-ekonomski položaj 70

Sočan, G. 112

stališča do šole $86,95,98,109,110,115$

Stanovic, K. E. 25, 111

Stanton, G. C. 150

strategije povzemanja besedila 81, 102

strategije razumevanja in pomnjenja 79

Strauss, A. 166, 198, 199

Svetina, M. 135, 151

Swann, W. B., Jr. 128, 131, 150

Š

Šterman Ivančič, K. 17, 37, 113, 201, 205

Štraus, M. 105, 113

T

Tafarodi, R. W. 128, 131, 150

Tauer, J. M. 127, 150 tekmovalnost $22,25,27,121,125,126,127$, 130, 131, 133, 134, 136, 138, 139, 142, 202

Tellegen, A. 151

Tice, D. M. 129, 146

Tough, A. 153, 160, 163, 199

Tripathi, K. N. 127,150

U

učna metoda 161

učne pogodbe 159, 161, 162

učne strategije $28,30,31,43,53,57,77,81$, $82,86,97,100,103,104,106,113,122$, 158, 201

učni pripomočki 161

uporaba IKT 35, 36, 86, 94, 110

V

Vallerand. R. J. 117, 119, 130, 150, 151

Vallieres, E.F. 130

W

Waschull, S. B. 129, 147, 148, 151

Watkins, D. 122, 151

Watson, D. 131, 151

Weinstein, C. E. 29, 30, 31, 113

Wellborn, J. G. 119, 146

Wheatman, S. 148

Whisenhunt, C. R. 147, 148

Whitaker, D. 148

Wigfield, A. 21, 22, 24, 25, 27, 44, 108, 111, 113, 114

Williams, G. C. 119, 151

Wilson, D. W. 125, 149 
Y

Yeung, A. S. 124, 149, 151

Z

Zimmerman, B. J. 28, 53, 114, 156, 157, 158, 200

Zupančič, M. 67, 113, 135, 151

Ž

Žalec, B. 148, 200 



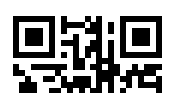 . 吕的}

